COVER

DH-59 suspended-sediment sampler with 1/4-inch nozzle. 
U.S. Department of the Interior

U.S. Geological Survey

\section{Suspended-Sediment Characteristics in the Housatonic River Basin, Western Massachusetts and Parts of Eastern New York and Northwestern Connecticut, 1994-96}

By GARDNER C. BENT

Water-Resources Investigations Report 00-4059

Prepared in cooperation with the

MASSACHUSETTS DEPARTMENT OF ENVIRONMENTAL MANAGEMENT,

DIVISION OF RESOURCE CONSERVATION,

OFFICE OF WATER RESOURCES 


\section{U.S. DEPARTMENT OF THE INTERIOR BRUCE BABBITT, Secretary}

U.S. GEOLOGICAL SURVEY

Charles G. Groat, Director

For additional information write to:

Chief, Massachusetts-Rhode Island District

U.S. Geological Survey

Water Resources Division

10 Bearfoot Rd.

Northborough, MA 01532

or through our website at
Copies of this report can be purchased from:

U.S. Geological Survey

Branch of Information Services

Box 25286

Denver, CO 80225-0286

\section{http://ma.water.usgs.gov}




\section{CONTENTS}

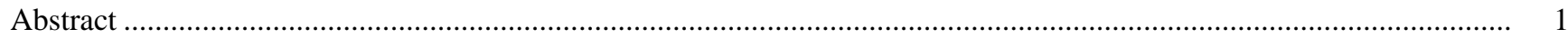

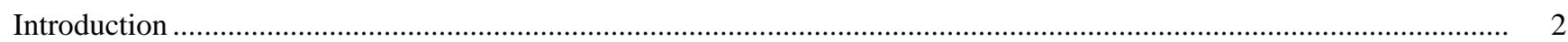

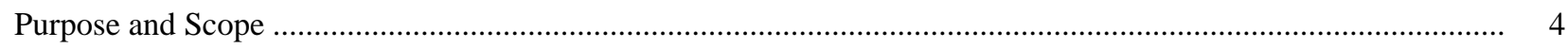

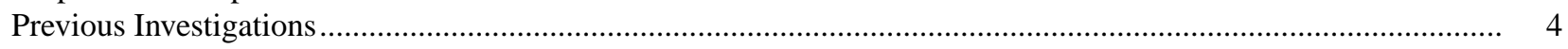

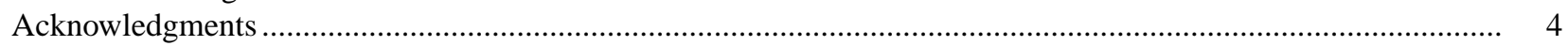

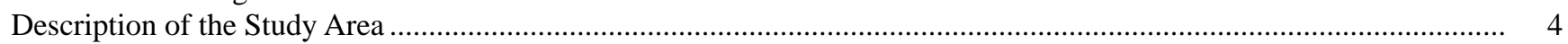

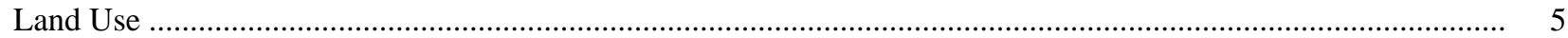

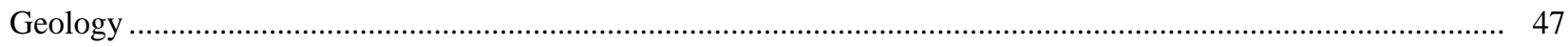

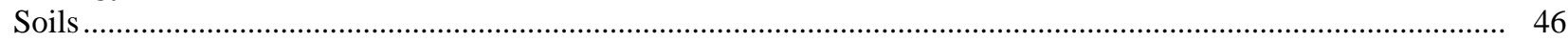

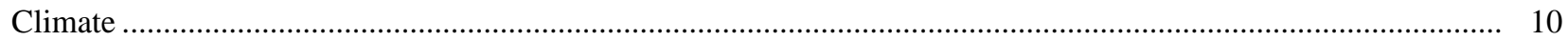

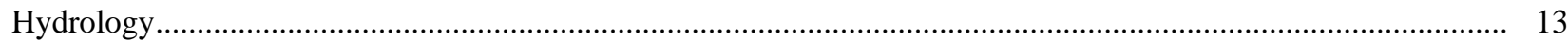

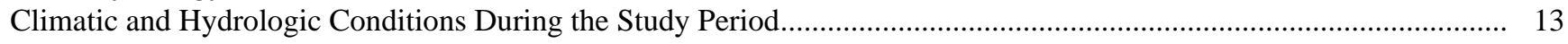

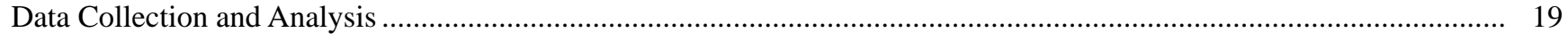

Collection of Samples for Suspended-Sediment Concentration .................................................................. 19

Calculation of Suspended-Sediment Discharge, Load, and Yield ................................................................. 20

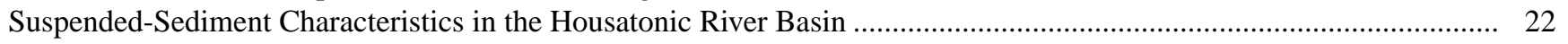

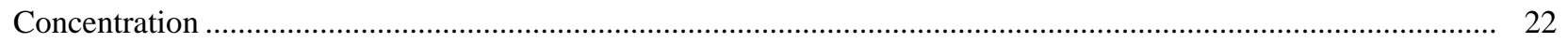

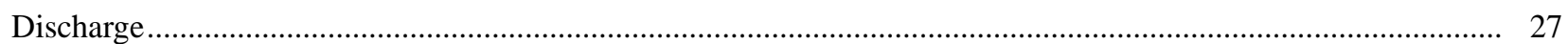

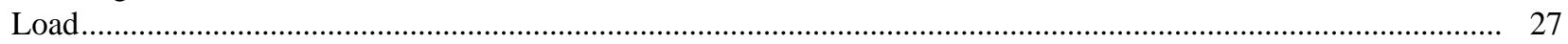

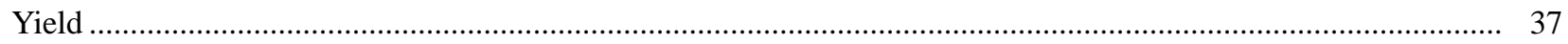

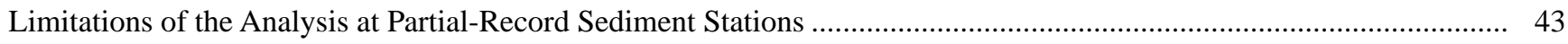

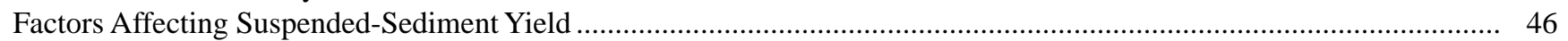

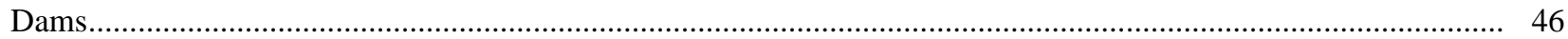

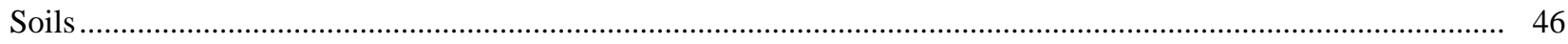

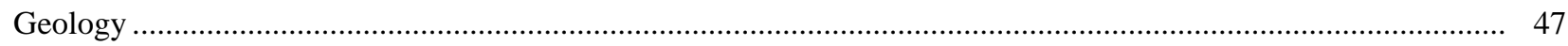

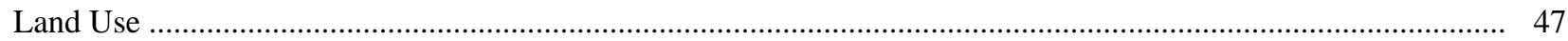

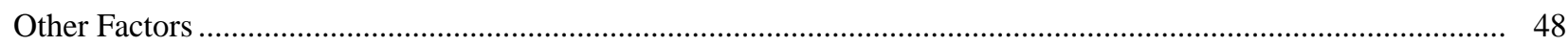

Comparison to Results of Other Suspended-Sediment Studies in the Northeastern United States ................................. 48

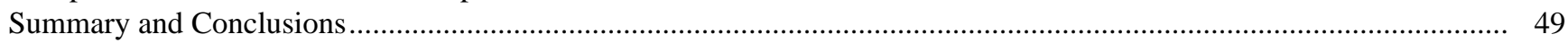

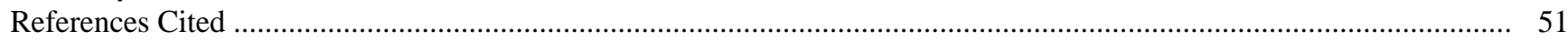

Appendix 1. Daily mean streamflow at partial-record sediment stations in the Housatonic River Basin, western Massachusetts, March 1994 through April 1996 ......................................................................... 57

Appendix 2. Instantaneous suspended-sediment and associated data at three continuous-record and four partial-record sediment stations in the Housatonic River Basin, western Massachusetts, March 1994 through April 1996........ 66

Appendix 3. Daily mean streamflow, daily mean suspended-sediment concentration, and daily total suspendedsediment discharge at three continuous-record sediment stations in the Housatonic River Basin, western Massachusetts, March 1994 through April 1996.

\section{FIGURES}

1-5. Maps showing:

1. Location of study area in the Housatonic River Basin, western Massachusetts and parts of eastern New York and northwestern Connecticut....

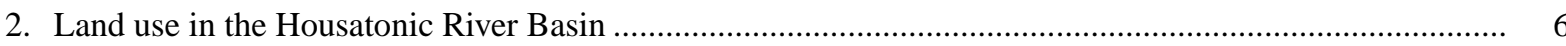

3. Distribution of underlying bedrock types and stratified drift and till deposits in the Housatonic River Basin

4. Distribution of the Hadley, Limerick, Linlithgo, Saco, and Winooski silt loam soils (higherodibility soils) in the Housatonic River Basin.

5. Climatological stations, dams, and continuous- and partial-record sediment stations in and near the Housatonic River Basin. 
6-12. Graphs showing:

6. Monthly precipitation at the Great Barrington Airport climatological station and streamflow and suspended-sediment yield at the three continuous-record sediment stations in the Housatonic River Basin, western Massachusetts, April 1994 through March 1996

7. Flow-duration curves of daily mean streamflow per square mile at six sediment stations in the Housatonic River Basin, western Massachusetts, April 1994 through March 1996.

8. Flow-duration curves of daily mean streamflow during selected periods at sediment stations at the Housatonic River near Great Barrington and Green River near Great Barrington, Mass.

9. Relation of instantaneous suspended-sediment concentration to concurrent streamflow and associated sediment-transport curves at six sediment stations in the Housatonic River Basin, western Massachusetts, March 1994 through April 1996

10. Relation of instantaneous suspended-sediment discharge to concurrent streamflow and associated sediment-transport curves at six sediment stations, in the Housatonic River Basin western Massachusetts, March 1994 through April 1996.

11. Relation of daily suspended-sediment discharge to daily mean streamflow and associated sedimenttransport curves for the Housatonic River near Great Barrington, Mass. (station 01197500), April 1979 through September 1980 and April 1994 through March 1996

12. Sediment-transport curves of instantaneous suspended-sediment yield to concurrent streamflow per square mile at six sediment stations in the Housatonic River Basin, western Massachusetts, March 1994 through April 1996

\section{TABLES}

1. Basin and land-use characteristics for continuous- and partial-record sediment stations in the

Housatonic River Basin, western Massachusetts, determined using a Geographic Information System..

2. Description of continuous- and partial-record sediment stations in the Housatonic River Basin

3. Minimum and maximum instantaneous streamflows recorded and minimum and maximum instantaneous streamflows sampled for suspended-sediment concentration at continuous- and partial-record sediment stations in the Housatonic River Basin, March 1994 through April 1996.

4. Normalized instantaneous streamflows, concentrations, and normalized yields for suspended-sediment samples at continuous- and partial-record sediment stations in the Housatonic River Basin, March 1994 through April 1996

5. Sediment-transport curve equations for continuous- and partial-record sediment stations in the Housatonic River Basin, April 1979 through September 1980 and April 1994 through March 1996

6. Computation of suspended-sediment discharge, load, and yield at three partial-record sediment stations in the Housatonic River Basin, April 1994 through March 1996

7. Streamflow and suspended-sediment load at continuous- and partial-record sediment stations in the Housatonic River Basin, April 1994 through March 1996

8. Precipitation, streamflow, suspended-sediment load, and suspended-sediment yield at the Housatonic River near Great Barrington, Massachusetts, in the Housatonic River Basin, April 1979 through September 1980 and April 1994 through March 1996

9. Suspended-sediment yield, streamflow, and selected basin and land-use characteristics for continuousand partial-record sediment stations in the Housatonic River Basin, April 1994 through March 1996

10. Comparison of suspended-sediment yield calculated using three methods for the three continuous-record sediment stations in the Housatonic River Basin, April 1979 through September 1980 and April 1994 through March 1996. 
CONVERSION FACTORS AND VERTICAL DATUM

\section{CONVERSION FACTORS}

\begin{tabular}{rll}
\hline Multiply & By & To obtain \\
cubic foot per second $\left(\mathrm{ft}^{3} / \mathrm{s}\right)$ & 0.02832 & cubic meter per second \\
cubic foot per second per square mile $\left[\left(\mathrm{ft}^{3} / \mathrm{s}\right) / \mathrm{mi}^{2}\right]$ & 0.01093 & cubic meter per second per square kilometer \\
foot $(\mathrm{ft})$ & 0.3048 & meter \\
foot per mile $(\mathrm{ft} / \mathrm{mi})$ & 490.728 & meter per kilometer \\
foot per second (ft/s) & 0.3048 & meter per second \\
inch (in.) & 25.4 & millimeter \\
inch per year (in/yr) & 2.54 & centimeter per year \\
mile (mi) & 1.609 & kilometer \\
square mile $\left(\mathrm{mi}^{2}\right)$ & 2.590 & square kilometer \\
ton, short (ton) & 0.90718 & megagram \\
ton per day (tons $/ \mathrm{d})$ & 0.90718 & megagram per day \\
ton per day per square mile $\left[(\right.$ tons $\left./ \mathrm{d}) / \mathrm{mi}^{2}\right)$ & 0.3503 & megagram per day per square kilometer \\
ton per square mile $\left(\right.$ tons $\left./ \mathrm{mi}^{2}\right)$ & 0.3503 & megagram per square kilometer \\
ton per year per square mile $\left[(\right.$ tons $\left./ \mathrm{yr}) / \mathrm{mi}^{2}\right]$ & 0.3503 & megagram per year per square kilometer \\
Temperature in degrees Fahrenheit $\left({ }^{\circ} \mathrm{F}\right)$ & can be converted to degrees Celsius $\left({ }^{\circ} \mathrm{C}\right)$ \\
as follows: ${ }^{\circ} \mathrm{C}=5 / 9\left({ }^{\circ} \mathrm{F}\right.$ & $-32)$. \\
\hline
\end{tabular}

Concentration of suspended sediment in water is in milligrams per liter $(\mathrm{mg} / \mathrm{L})$.

Particle size of suspended sediment is in millimeters ( $\mathrm{mm})$.

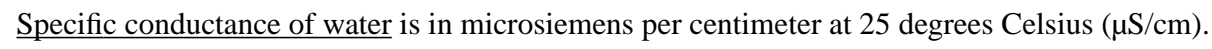

VERTICAL DATUM

Sea level: In this report, "sea level" refers to the National Geodetic Vertical Datum of 1929 (NGVD of 1929) - a geodetic datum derived from a general adjustment of the first-order level nets of the United States and Canada, formerly called Sea Level Datum of 1929. 



\title{
Suspended-Sediment Characteristics in the Housatonic River Basin, Western Massachusetts and Parts of Eastern New York and Northwestern Connecticut, 1994-96
}

\author{
By Gardner C. Bent
}

\section{Abstract}

Suspended-sediment concentrations, discharges, loads, and yields were determined for eight subbasins in the Housatonic River Basin in western Massachusetts, eastern New York, and northwestern Connecticut from April 1994 through March 1996. Suspended-sediment samples were collected at three continuous-record sediment stations and at four partial-record sediment stations. Suspended-sediment concentrations in samples collected during the period of study ranged from less than 0.5 to 3,400 milligrams per liter, and concurrent streamflows ranged from 0.03 to 126 cubic feet per second per square mile at the seven stations. Median suspended-sediment concentrations in samples collected at each station ranged from 7 to 61 milligrams per liter. Median streamflows during suspended-sediment sampling ranged from 1.86 to 5.88 cubic feet per second per square mile. Instantaneous suspended-sediment yields ranged from less than 0.005 to 185 tons per day per square mile, and medians ranged from 0.03 to 1.12 tons per day per square mile at the seven stations.

Total suspended-sediment loads (mass) from April 1994 through March 1996 at the continuous-record sediment stations were 11,603 tons at Housatonic River near Great Barrington, 7,929 tons at Green River, and 54,347 tons at Housatonic River near Ashley Falls.
Suspended-sediment load during January 1996 at the Green River station accounted for about 54 percent of the total suspended-sediment load for the Green River during the 2-year study. Suspended-sediment load on January 19 and 20, 1996, at the Green River station accounted for about 50 percent of the January 1996 suspendedsediment load, or about 27 percent of the total suspended-sediment load during the 2-year study. This large suspended-sediment transport was the result of rainfall and snowmelt on January 19 and 20,1996-the equivalent of a 5- to 6-inch rain storm in the Green River subbasin. Total suspended-sediment loads during the 2-year study at the partial-record sediment stations were 3,052 tons at Williams River, 1,758 tons at Ironworks Brook, and 17,927 tons at Konkapot River.

Suspended-sediment yields from April 1994 through March 1996 at the continuousrecord sediment stations were 21 (tons/yr) $/ \mathrm{mi}^{2}$ at Housatonic River near Great Barrington, 78 (tons $/ \mathrm{yr}$ ) $/ \mathrm{mi}^{2}$ at Green River, and 58 (tons/yr) $/ \mathrm{mi}^{2}$ at Housatonic River near Ashley Falls. Suspended-sediment yields during the 2year study at the partial-record sediment stations were 35 (tons/yr) $/ \mathrm{mi}^{2}$ at Williams River, 78 (tons/yr) $/ \mathrm{mi}^{2}$ at Ironworks Brook, and 147 (tons/yr)/mi ${ }^{2}$ at Konkapot River. Suspendedsediment yields were estimated for two subbasins in the Housatonic River Basin-Schenob Brook at 
Sheffield, a partial-record sediment station, and the area adjacent to the Housatonic River between Great Barrington and Ashley Falls. The estimate of suspended-sediment yield at Schenob Brook at Sheffield of 82 (tons/yr) $/ \mathrm{mi}^{2}$ is comparable to the yield determined for the Green River and Ironworks Brook. The estimate of suspendedsediment yield for the area adjacent to the Housatonic River between Great Barrington and Ashley Falls was 395 (tons/yr)/mi ${ }^{2}$. This estimated suspended-sediment yield was 2.7 to 18.8 times greater than that estimated for any of the other subbasins.

Several basin and land-use characteristics thought to affect suspended-sediment transport in the subbasins were compared to the suspendedsediment yields. The characteristics that seemed to affect suspended-sediment discharge were dams, which contributes to decreased yields; Hadley, Limerick, Linlithgo, Saco, and Winooski silt loam soils (high erodibility soils), which contributes to increased yields; stratified-drift deposits, which contributes to increased yields; and agricultural and open land, which contributes to increased yields. The effect of stratified-drift deposits on suspended-sediment discharge is thought to be greater when those deposits are of glaciolacustrine (generally clay, silt, and fine sand), rather than glaciofluvial (clay, silt, sand, gravel, and cobbles) origin. The silt loam soils, glaciolacustrine deposits, and agricultural and open land are interrelated, inasmuch as the silt loam soils generally are associated with glaciolacustrine deposits and agricultural activities.

\section{INTRODUCTION}

The concentration, discharge, load, and yield of suspended sediments in a stream are important because of the relation between sediments and some water-quality constituents that have a strong association to sediments. Trace metals, pesticides, and polychlorinated biphenyls (PCBs) have a strong affinity for and sorb to soils, sediments, and other particulate matter present in the environment. The movement and distribution of these constituents in a river results from a continuous process of sorbtion to fine-grained sediments and other particulate matter, movement downstream (primarily in suspension), deposition, resuspension, movement, redeposition, and so on, in response to variations in streamflow. Suspended-sediment concentration, discharge, load, and yield data also are important for (1) protecting recreation on rivers, lakes, and ponds (esthetics); (2) evaluating potential adverse effects on aquatic habitat (for example, burial of fish eggs); (3) evaluating potential sedimentation of reservoirs, lakes, and ponds; (4) designing water-treatment plants; and (5) designing reservoirs.

Thirty-two communities are partly or completely within the Housatonic River Basin in western Massachusetts and parts of eastern New York and northwestern Connecticut (fig. 1). Nine of the Massachusetts communities obtain at least part of their public-water supplies from surface-water sources on tributaries to the Housatonic River. Water from the Housatonic River and its tributaries also is used for hydroelectric-power generation, paper and pulp manufacturing, fishing, and recreation. A better understanding of suspended-sediment concentration, discharge, load, and yield in the Housatonic River Basin could be used to evaluate human uses as well as to maintain stream habitat for fish and wildlife.

In March 1994, the U.S. Geological Survey (USGS) in cooperation with the Massachusetts Department of Environmental Management (MDEM), Division of Resource Conservation, Office of Water Resources began a study of suspended-sediment characteristics in the Housatonic River Basin. This study is one of several carried out under the Massachusetts Chapter 800 legislation of 1979, which supports quantitative assessments of ground-water resources and related hydrologic studies in basins of Massachusetts. This report could be used to assist management and policy decisions by providing (1) a better understanding of suspended-sediment concentrations, discharges, loads, and yields in the Housatonic River Basin, (2) baseline data on these suspended-sediment characteristics, and (3) an understanding of the relation between suspendedsediment yields and basin and land-use characteristics. 


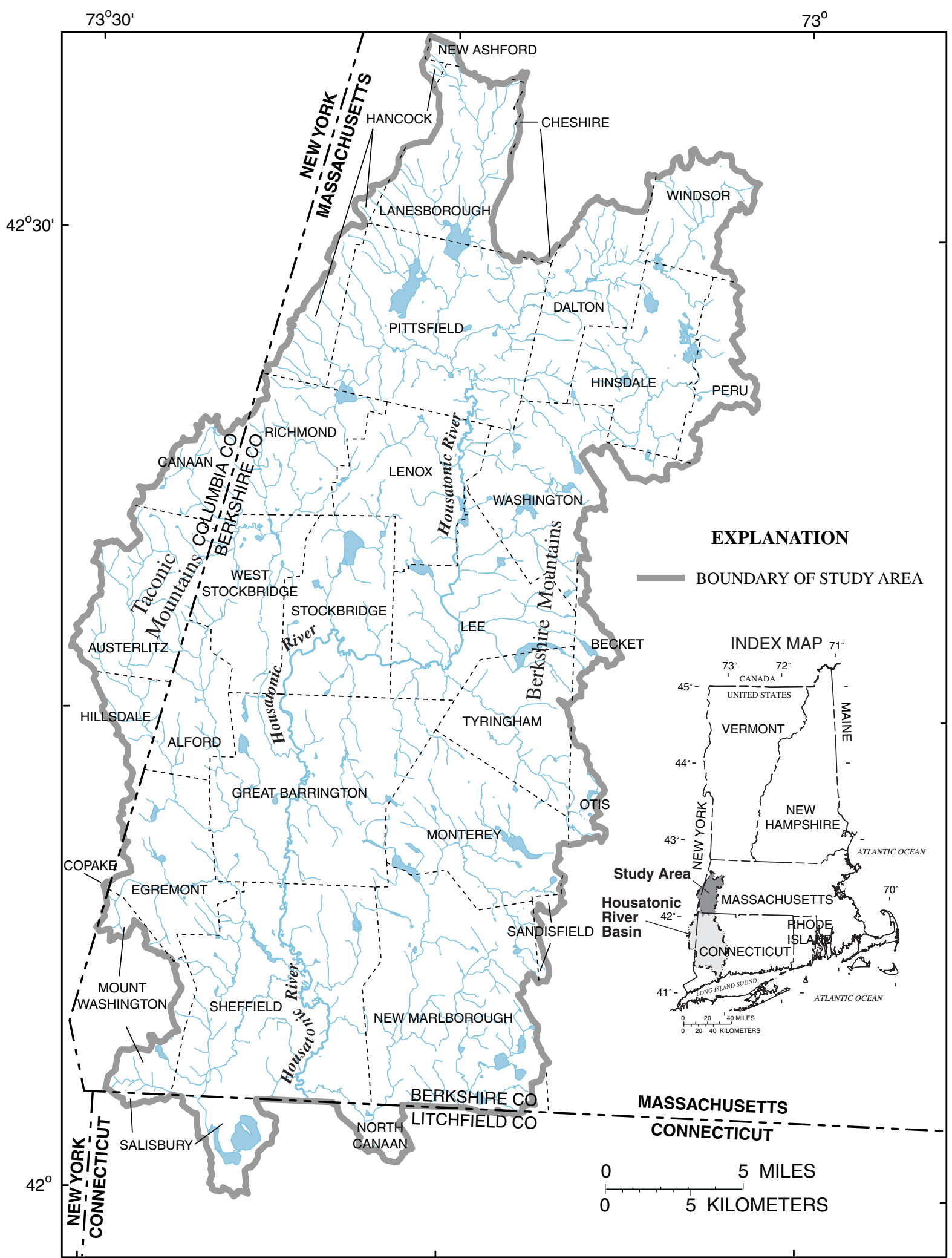

Base from U.S. Geological Survey Digital Line Graphs, 1:100,000,

1989 Universal Transverse Mercator Projection, Zone 18

Figure 1. Location of study area in the Housatonic River Basin, western Massachusetts and parts of eastern New York and northwestern Connecticut. 


\section{Purpose and Scope}

The purpose of this report is to provide information on suspended-sediment concentrations, discharges, loads, and yields in part of the Housatonic River Basin in western Massachusetts, eastern New York, and northwestern Connecticut from April 1994 through March 1996. Suspended-sediment characteristics were determined at two sites on the Housatonic River, the area adjacent to the Housatonic River between these two sites, and at five sites on tributaries to the Housatonic River. Suspendedsediment yield also was estimated for that part of the study area draining to the Housatonic River upstream from the Massachusetts-Connecticut State border. Limitations of the analysis at partial-record stations and comparison to results of other sediment studies in the northeastern United States are discussed. In addition, the relation between suspended-sediment yields and basin and land-use characteristics of the study area were evaluated.

\section{Previous Investigations}

In the late 1970's and early 1980's, several areas of the Housatonic River Basin were investigated for distribution and transport of PCBs. The results of these investigations are presented in Frink and others (1982), Gay and Frimpter (1985), Kulp and Gay (1986), and Kulp (1991a). Additional information regarding the distribution and transport of PCBs in the Housatonic River Basin has been published by other Federal and State agencies and consulting firms. This information is available from the Massachusetts Department of Environmental Protection (Springfield, Mass.) and the U.S. Environmental Protection Agency (Boston, Mass.). The trace elements copper, lead, mercury, zinc, and the organic compounds dichlorodiphenyltrichloroethane (DDT), polyaromatic hydrocarbons (PAHs), and PCBs, which may adversely affect aquatic life, were found in the streambed sediments of the Housatonic River Basin (Harris, 1997; Breault and Harris, 1997).

\section{Acknowledgments}

The author thanks Nicholas Diller (WSBS radio station, Great Barrington, Mass.) and John Guarnieri (NOAA volunteer, Great Barrington Airport, Mass.) for providing precipitation data for the study. The author also extends thanks to the State and municipal officials and the many private landowners who granted permission for the USGS to install stream-stage instruments on their property and for access to measurement sites. Special thanks and appreciation are given to USGS volunteers William Harwood, John and Susan Hugel, and Martin Keane, who made streamstage readings; Frederick Ruggles and Christopher Windram, who collected suspended-sediment samples, stream-stage readings, and air and water temperature readings in the study area; and Kim Kutawski, for field assistance.

\section{DESCRIPTION OF THE STUDY AREA}

The 1,953-square-mile Housatonic River Basin drains $504 \mathrm{mi}^{2}$ of western Massachusetts, $217 \mathrm{mi}^{2}$ of eastern New York, and 1,232 $\mathrm{mi}^{2}$ of western Connecticut before discharging into Long Island Sound. The 540-square-mile area studied for this investigation (fig. 1) is confined to $504 \mathrm{mi}^{2}$ in Massachusetts, $26 \mathrm{mi}^{2}$ in New York, and $10 \mathrm{mi}^{2}$ in Connecticut. The study area has 26 communities in Berkshire County, Massachusetts; 4 communities in Columbia County, New York; and 2 communities in Litchfield County, Connecticut.

The central part of the study area is the lowland area of the Housatonic River Valley and is bordered by the Berkshire Mountains to the east and the Taconic Mountains to the west (fig. 1). Elevations in the study area range from about $635 \mathrm{ft}$ above sea level at the Massachusetts-Connecticut border to about 2,600 ft above sea level in the headwaters near Hancock (Simcox, 1992). 


\section{Land Use}

The study area is mainly rural with sparsely settled woodlands, agricultural lands, and wetlands (fig. 2). More specifically, the land is approximately 67 percent forested, 12 percent agricultural/open, 10 percent urban, 7 percent wetland (forested and nonforested), 2 percent water bodies, and 2 percent barren (fig. 2). Basin and land-use characteristics for subbasins in the Housatonic River Basin where suspended-sediment data were collected are listed in table 1. Land-use information is derived from geographic information system data layers (MassGIS, 1997, p. 72 and 73). Several State forests, a State park, State areas of critical environmental concerns, and a segment of the Appalachian Trail are in the study area. The only major urban and suburban area is around the city of Pittsfield, Mass. (fig. 1). Agricultural land is mainly in the Housatonic River Valley in the southern half of the study area. The study area contains 113 ponds and lakes, 70 of which are larger than $0.02 \mathrm{mi}^{2}$ (Michele Drury, Massachusetts Department of Environmental Management, written commun., 1997). The population in the study area was reported to be about 95,000 people in the mid-1960's (Norvitch and others, 1968, sheet 1) and 92,000 people in 1990. The population is expected to continue to decline slightly until 2010 and increase thereafter (Michele Drury, Massachusetts Department of Environmental Management, written commun., 1997).

\section{Geology}

The lowlands of the Housatonic River Valley in the study area are underlain primarily by carbonate rocks (mostly limestone, dolomite, and marble), the Berkshire Mountains are primarily gneissic rocks (mostly granite biotite gneiss) with small areas of quartzitic rocks (mostly quartzite, quartzite conglomerate, and feldspathic quartzite), and the Taconic Mountains are primarily schistose rocks (mostly quartz-mica schist) (Norvitch and others, 1968, sheet 4) (fig. 3). The depth to bedrock ranges from land surface to $300 \mathrm{ft}$ or more below land surface in the southern part of the study area in the Housatonic River Valley, and from land surface to $150 \mathrm{ft}$ below land surface in upland stream valleys (Norvitch and others, 1968, sheet 4). A bedrock map, constructed on the basis of tectonic and lithochemical characteristics and physiography produced for the Connecticut, Housatonic, and Thames River Basins, as a part of the USGS National Water-Quality Assessment Program (Robinson and others, 1999), is consistent with the bedrock description by Norvitch and others (1968, sheet 4).

Surficial materials that were deposited during the last glacial period overlie most of the bedrock in the study area. The last glacial period began with the southeastward advance of the Hudson-Champlain ice lobe of the Laurentide ice sheet across the study area about 28,000 years ago (Warren and Stone, 1986, p. 172, 190). The retreat of the glacial ice lobe began about 19,000 to 20,000 years ago (J.R. Stone, U.S. Geological Survey, oral commun., 1997) and ended before 14,000 years ago (Warren and Stone, 1986, p. 190). Surficial deposits in the upland areas are primarily till, an unsorted, unstratified mixture of clay, silt, sand, gravel, cobbles, and boulders, that was deposited by glaciers and underlies about 83 percent of the study area. The till is sandy and ranges from 0 to $50 \mathrm{ft}$ in thickness (Warren and Stone, 1986, p. 174).

Stratified-drift deposits overlie till primarily in the upland stream valleys and in the Housatonic River Valley, and underlie about 17 percent of the study area (fig. 3). Stratified drift is a common term for sorted and layered glaciofluvial and glaciolacustrine deposits. Glaciofluvial deposits are materials of all grain sizes (clay, silt, sand, gravel, and cobbles) deposited by glacial meltwater streams in outwash plains and valleys. Glaciolacustrine deposits generally consist of clay, silt, and fine sand deposited in lakes that existed for only short periods after the retreat of the glacial ice sheet. The stratified-drift deposits in the Housatonic River Basin are primarily glaciolacustrine deposits, derived from glacial lakes in the Housatonic River Valley and the valleys of its major tributaries that drain from the northwest (Warren and Stone, 1986, p. 177, 190). Norvitch and others (1968, sheet 4) report that sediment grains in stratified-drift deposits generally are coarser in the upland stream valleys than in the Housatonic River Valley. The Housatonic River Valley was occupied during the last glacial period by two glacial lakes (Warren and Stone, 1986, p. 177), which would account in part for the finer sediment grains in the valley. The stratified-drift deposits range in thickness from 0 to about $150 \mathrm{ft}$ in upland valleys and from 0 to more than $300 \mathrm{ft}$ in the Housatonic River Valley (Norvitch and others, 1968, sheet 4). 


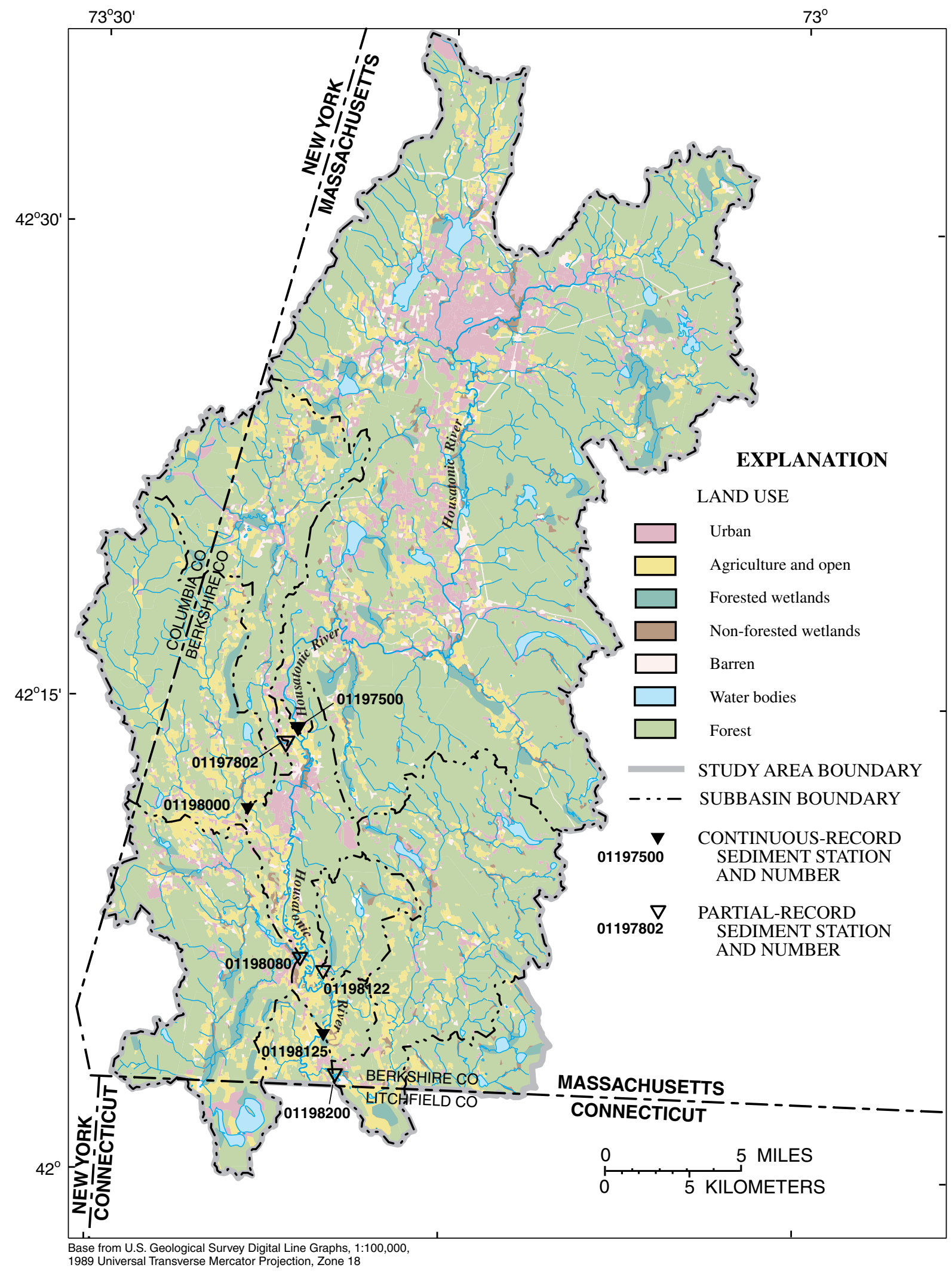

Figure 2. Land use in the Housatonic River Basin, western Massachusetts and parts of eastern New York and northwestern Connecticut. 
Table 1. Basin and land-use characteristics for continuous- and partial-record sediment stations in the Housatonic River Basin, western Massachusetts, determined using a Geographic Information System

[USGS station No.: Locations shown in figure 5 and described in table 2. Basin relief: The difference between maximum and minimum basin elevation. Total soils with soil erodibility factor of 0.49 equals the sum of Hadley, Limerick, Linlithgo, Saco, and Winooski silt loam soils. GIS, Geographic Information System; GRID and TIN, surface modeling packages in ARCINFO; No., number; USGS, U.S. Geological Survey; ft, foot; $\mathrm{mi}$, mile; $\mathrm{mi} / \mathrm{mi}^{2}$, mile per square mile; $\mathrm{mi}^{2}$, square mile]

\begin{tabular}{|c|c|c|c|c|c|c|c|c|c|c|c|}
\hline $\begin{array}{l}\text { USGS } \\
\text { station } \\
\text { No. }\end{array}$ & $\begin{array}{l}\text { Station name } \\
\text { and location }\end{array}$ & $\begin{array}{c}\text { Drainage } \\
\text { area } \\
\left(\mathrm{mi}^{2}\right)\end{array}$ & $\begin{array}{l}\text { GIS- } \\
\text { deter- } \\
\text { mined } \\
\text { drainage } \\
\text { area } \\
\left(\mathrm{mi}^{2}\right)\end{array}$ & $\begin{array}{l}\text { Minimum } \\
\text { basin } \\
\text { elevation, } \\
\text { above sea } \\
\text { level } \\
\text { (ft) }\end{array}$ & $\begin{array}{l}\text { Maximum } \\
\text { basin } \\
\text { elevation, } \\
\text { above sea } \\
\text { level } \\
\text { (ft) }\end{array}$ & $\begin{array}{l}\text { Mean basin } \\
\text { elevation, } \\
\text { above sea } \\
\text { level } \\
\text { (ft) }\end{array}$ & $\begin{array}{c}\text { Basin } \\
\text { relief } \\
\text { (ft) }\end{array}$ & $\begin{array}{c}\text { Mean basin } \\
\text { slope (GRID) } \\
\text { (percent) }\end{array}$ & $\begin{array}{c}\text { Mean basin } \\
\text { slope (TIN) } \\
\text { (percent) }\end{array}$ & $\begin{array}{c}\text { Stream } \\
\text { length } \\
(\mathrm{mi})\end{array}$ & $\begin{array}{l}\text { Stream } \\
\text { density } \\
\left(\mathrm{mi} / \mathrm{mi}^{2}\right)\end{array}$ \\
\hline
\end{tabular}
bridge on Division Street

01198000 Green River near Great Barrington at bridge on Hurlburt Road

01198125 Housatonic River near Ashley Falls at bridge on U.S. Highway 7

01197802 Williams River near Great Barrington at railroad bridge $200 \mathrm{ft}$ south of Division Street

01198080 Schenob Brook at Sheffield at bridge on U.S. Highway 7

01198122 Ironworks Brook at Sheffield at bridge on East Road

01198200 Konkapot River at Ashley Falls at bridge on U.S. Highway 7

51.0

51.0

699

1,999

468

646

2,594

$1,169 \quad 1,300$

9.49

14.6

$1,267 \quad 1,948 \quad 8.04$

$\begin{array}{lll}15.1 & 682 & 1.46\end{array}$

Partial-Record Sediment Stations

43.2

$\begin{array}{lll}44.1 & 744 & 1,990\end{array}$

50.0

50.8

658

11.2

11.2

681

2,528

1,179

1,246

8.74

14.6

$63.7 \quad 1.44$

61.1

61.0

646

2,021
$1,020 \quad 1,870$

8.06

$1,049 \quad 1,022 \quad 8.20$

$\begin{array}{lll}1,235 & 1,375 \quad 6.78\end{array}$

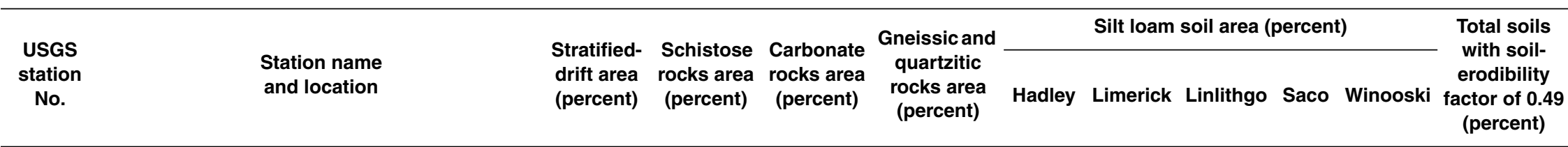

Continuous-Record Sediment Stations

01197500 Housatonic River near Great Barrington at bridge

$\begin{array}{llll}13.4 & 13.9 & 36.8 & 49.4\end{array}$

0

on Division Street

01198000 Green River near Great Barrington at bridge on Hurlburt Road

01198125 Housatonic River near Ashley Falls at bridge on U.S. Highway 7

10.1

15.9
64.1

24.0
34.5

42.5
1.5

33.5

$0.2 \quad 1.2$

.1

.4

.6
1.5

.

$\begin{array}{lll}.0 & .0 & .8 \\ .0 & .9 & .7\end{array}$


Table 1. Basin and land-use characteristics for continuous- and partial-record sediment stations in the Housatonic River Basin, western Massachusetts, determined using a Geographic Information System—Continued

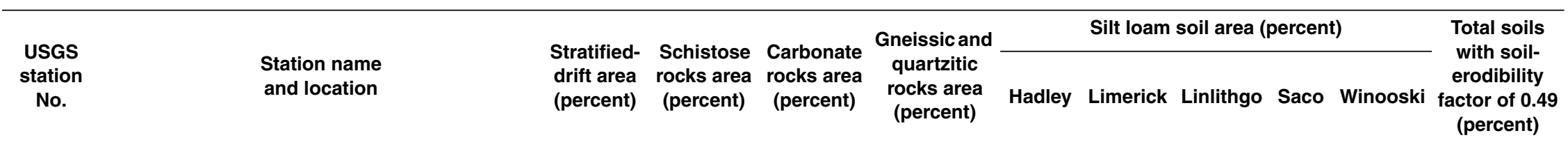

Partial-Record Sediment Stations

01197802 Williams River near Great Barrington at railroad bridge $200 \mathrm{ft}$ south of Division Street

01198080 Schenob Brook at Sheffield at bridge on U.S. 25.6 Highway 7

01198122 Ironworks Brook at Sheffield at bridge on East Road

01198200 Konkapot River at Ashley Falls at bridge on U.S. Highway 7

$\begin{array}{lllllllll}49.8 & 46.6 & 3.6 & 0.1 & 0.9 & 0.0 & 0.1 & 0.1 & 1.2\end{array}$

$30.6 \quad 69.6$

.4

.0

$\begin{array}{llll}3.6 & 5.6 & 56.8 & 37.8\end{array}$

17.4

5.9

$$
43.4
$$

50.8

$\begin{array}{ccc}\text { Urban } & \begin{array}{c}\text { Agricul- } \\ \text { tural and }\end{array} & \begin{array}{c}\text { Forest } \\ \text { area } \\ \text { (percent) } \\ \text { open area } \\ \text { (percent) }\end{array}\end{array} \quad \begin{gathered}\text { area } \\ \text { (percent) }\end{gathered}$

Water
bodies
area
(percent)

$\begin{array}{ccc}\begin{array}{c}\text { Forested } \\ \text { wet- } \\ \text { lands } \\ \text { area }\end{array} & \begin{array}{c}\text { Non- } \\ \text { forested } \\ \text { wetlands } \\ \text { area }\end{array} & \begin{array}{c}\text { Total } \\ \text { wetlands } \\ \text { area } \\ \text { (percent) }\end{array}\end{array}$

\section{Total}

wetlands

+water Barren Road

station

Station name

(percent)

(percent) (percent)

(percent)

bodies

area
(percent)

$\begin{array}{cc}\text { (percent) } & \left(\mathrm{mi} / \mathrm{mi}^{2}\right)\end{array}$

Continuous-Record Sediment Stations

01197500 Housatonic River near Great Barrington at bridge $\quad 12.7$ on Division Street

01198000 Green River near Great Barrington at bridge on Hurlburt Road

01198125 Housatonic River near Ashley Falls at bridge on 10.6 U.S. Highway 7

01197802 Williams River near Great Barrington at railroad $\quad 7.6$ bridge $200 \mathrm{ft}$ south of Division Street

01198080 Schenob Brook at Sheffield at bridge on U.S. $\quad 8.3$ Highway 7

01198122 Ironworks Brook at Sheffield at bridge on East $\quad 2.4$ Road

01198200 Konkapot River at Ashley Falls at bridge on U.S. Highway 7

$\begin{array}{rrrrrrrrr}8.4 & 66.7 & 2.2 & 4.0 & 3.2 & 7.2 & 9.5 & 2.9 & 3.19 \\ 17.7 & 74.6 & .5 & 1.7 & .8 & 2.5 & 3.1 & 1.0 & 1.37 \\ 11.8 & 66.2 & 1.6 & 4.0 & 3.2 & 7.2 & 8.8 & 2.5 & 2.72 \\ & & & & & & & & \\ 1\end{array}$




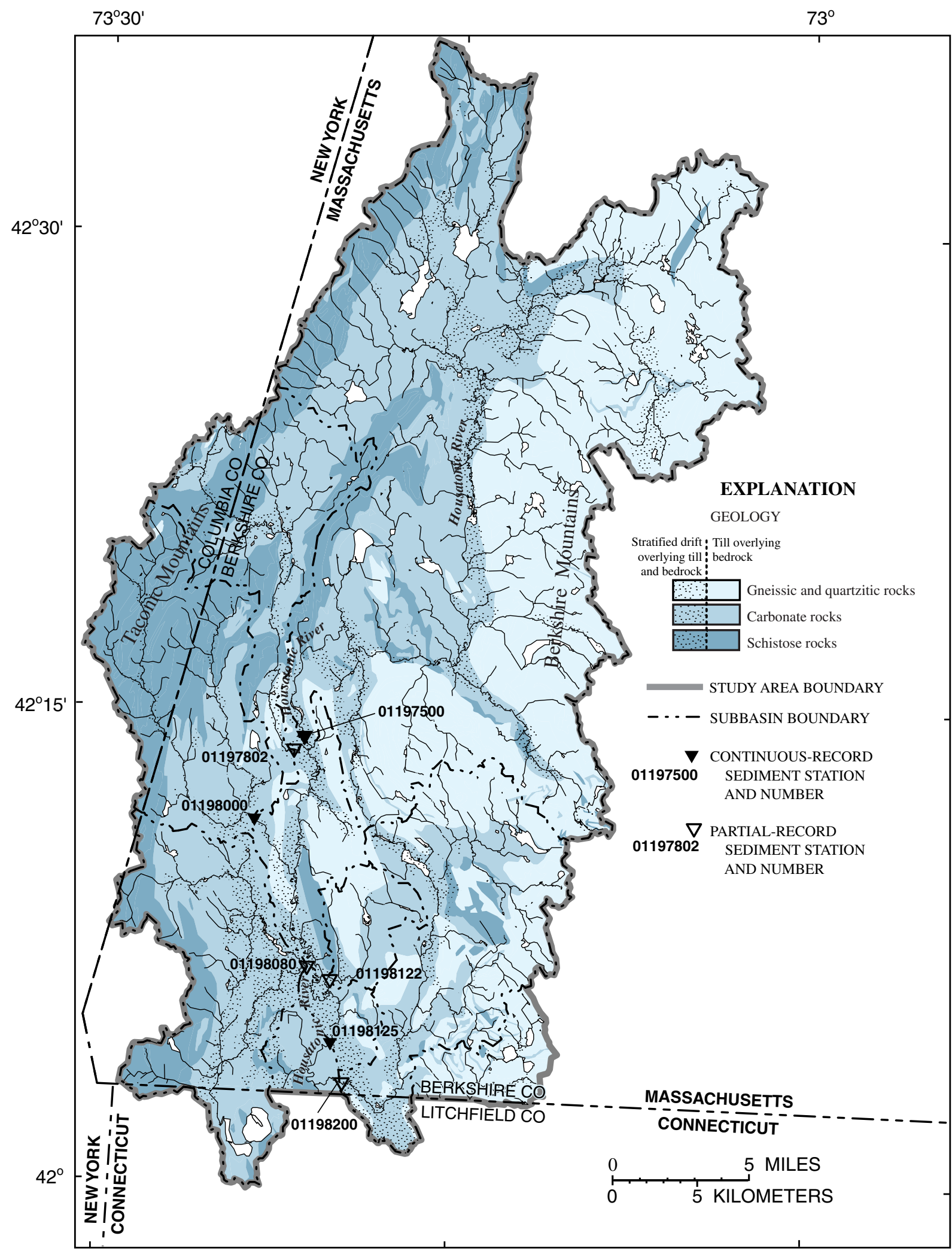

Base from U.S. Geological Survey Digital Line Graphs, 1:100,000,

1989 Universal Transverse Mercator Projection, zone 18

Figure 3. Distribution of underlying bedrock types and stratified drift and till deposits in the Housatonic River Basin, western Massachusetts and parts of eastern New York and northwestern Connecticut. 


\section{Soils}

General soil map units mainly in the lowlands of the Housatonic River Valley are the Copake-HeroHoosic from Pittsfield to Lee, Amenia-PittsfieldFarmington from Stockbridge to Great Barrington, and Limerick-Saco-Winooski in Sheffield (U.S. Department of Agriculture, Soil Conservation Service, 1988). General soil map units mainly in the Berkshire Mountains are the Tunbridge-Lyman-Peru and mainly in the Taconic Mountains are the Taconic-MacomberLanesboro.

The Copake-Hero-Hoosic soil map unit is a loamy soil formed in glacial outwash on gravelly glacial outwash plains and terraces (U.S. Department of Agriculture, Soil Conservation Service, 1988, p. 10-12). The Amenia-Pittsfield-Farmington soil map unit is a loamy soil formed in glacial till mainly derived from carbonate rocks (U.S. Department of Agriculture, Soil Conservation Service, 1988, p. 8-10). The Limerick-Saco-Winooski soil unit is a loamy soil formed in alluvial deposits on flood plains (U.S. Department of Agriculture, Soil Conservation Service, 1988, p. 12-13). The Tunbridge-LymanPeru soil map unit is a loamy soil formed in glacial till mainly derived from gneissic and quartzitic rocks (U.S. Department of Agriculture, Soil Conservation Service, 1988, p. 7). The TaconicMacomber-Lanesboro soil map unit is a loamy soil formed in glacial till mainly derived from schistose rocks (U.S. Department of Agriculture, Soil Conservation Service, 1988, p. 7 and 8).

Specific soils of importance for this study include the Hadley, Limerick, Linlithgo, Saco, and Winooski silt loam soils, which have a reported soil-erodibility factor (K-factor) of 0.49 (U.S. Department of Agriculture, Soil Conservation Service, 1970; 1988; 1989). The soil-erodibility factor is a component of the Universal Soil Loss Equation (Wischmeier and Smith, 1978), which is used to calculate soil erosion. The other 53 soils in the Massachusetts part of the study area have an average K-factor of 0.23 and range from 0.10 to 0.43 (U.S. Department of Agriculture, Soil Conservation Service, 1988). The higher the K-factor, the more erodible a soil is. Thus, the Hadley, Limerick, Linlithgo, Saco, and Winooski silt loam soils are the most erodible soils in the study area.
These silt loam soils tend to be adjacent to stream channels in the study area, especially in the southern part of the basin (fig. 4).

\section{Climate}

Three climatological stations have been operated by the National Oceanic and Atmospheric Administration (NOAA) in the Massachusetts part of the study area (fig. 5). Climatological data were collected at Lanesborough, Mass. (station 194075), from 1971-79, 1981-84, 1987-90, and 1993; Great Barrington Airport, Mass. (station 193213), from 1961-90; and Stockbridge, Mass. (station 198181), from 1951-80 (U.S. Department of Commerce, National Oceanic Atmospheric Administration, 1983, 1993). Mean monthly temperatures at Lanesborough ranged from $19.0^{\circ} \mathrm{F}$ in January to $66.4^{\circ} \mathrm{F}$ in July, with an annual mean for the period of record of $43.4^{\circ} \mathrm{F}$. Mean monthly temperatures at Great Barrington Airport ranged from $20.1{ }^{\circ} \mathrm{F}$ in January to $68.1^{\circ} \mathrm{F}$ in July, with an annual mean for the period of record of $45.2^{\circ} \mathrm{F}$. Mean monthly temperatures at Stockbridge ranged from $21.6^{\circ} \mathrm{F}$ in January to $66.2^{\circ} \mathrm{F}$ in August, with an annual mean for the period of record of $45.6^{\circ} \mathrm{F}$.

Mean annual precipitation for the periods of record was $48.8 \mathrm{in}$. at Lanesborough (station 194075), 43.9 in. at Great Barrington Airport (station 193213), and 44.8 in. at Stockbridge (station 198181). Precipitation was distributed uniformly throughout the year at the three stations. February was the driest month, when mean precipitation was about 2.9 in. at Great Barrington Airport and 2.7 in. at Stockbridge. August was the wettest month, when mean precipitation was about 4.3 in. at Great Barrington Airport and 4.6 in. at Stockbridge. At Lanesborough, February was the driest month (3.2 in.), and May was the wettest month (5.3 in.). Mean annual snowfall at Stockbridge was about 71.4 in. (U.S. Department of Agriculture, Soil Conservation Service, 1988, p. 138). 


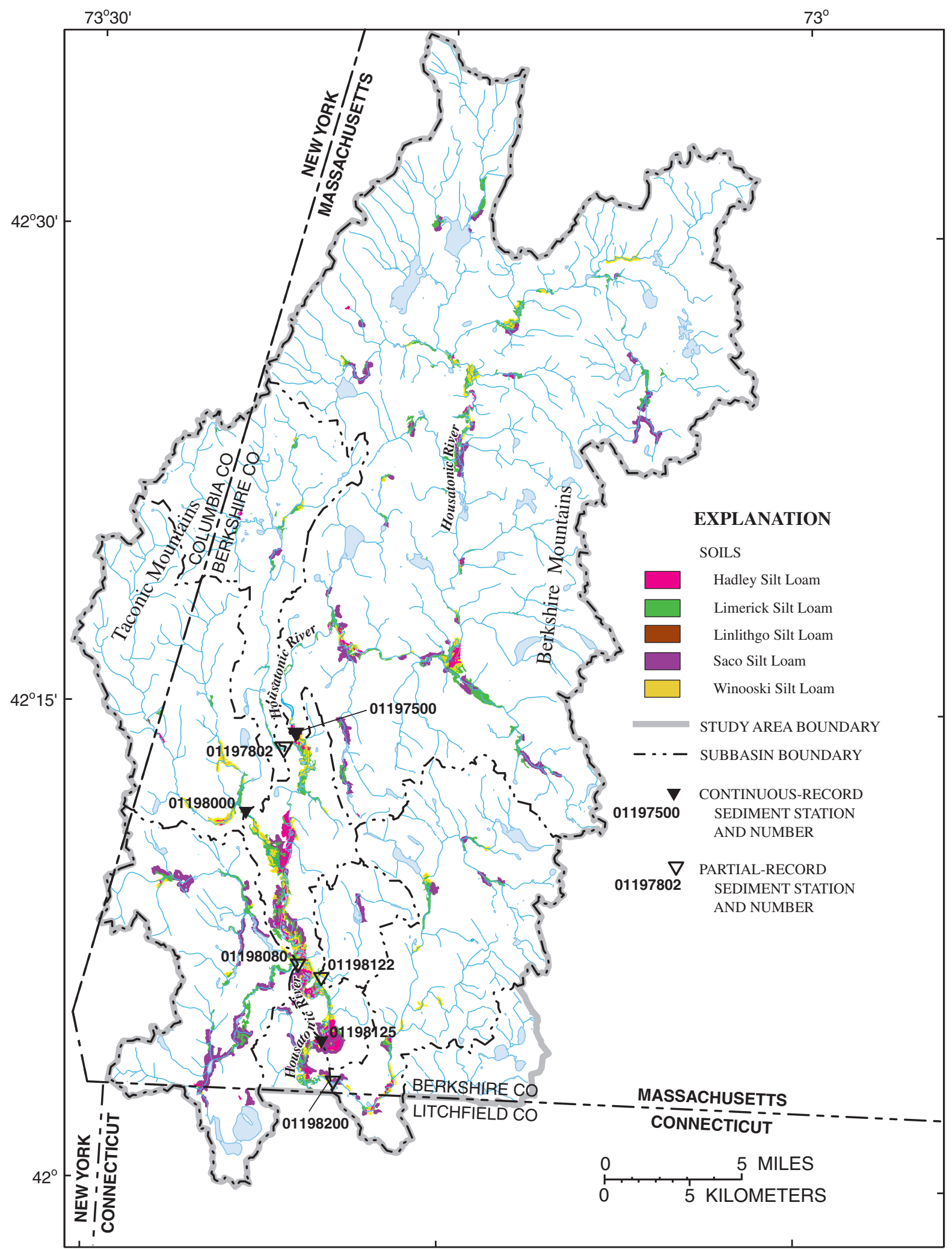

Figure 4. Distribution of the Hadley, Limerick, Linlithgo, Saco, and Winooski silt loam soils (high-erodibility soils) in the Housatonic River Basin, western Massachusetts and parts of eastern New York and northwestern Connecticut. 


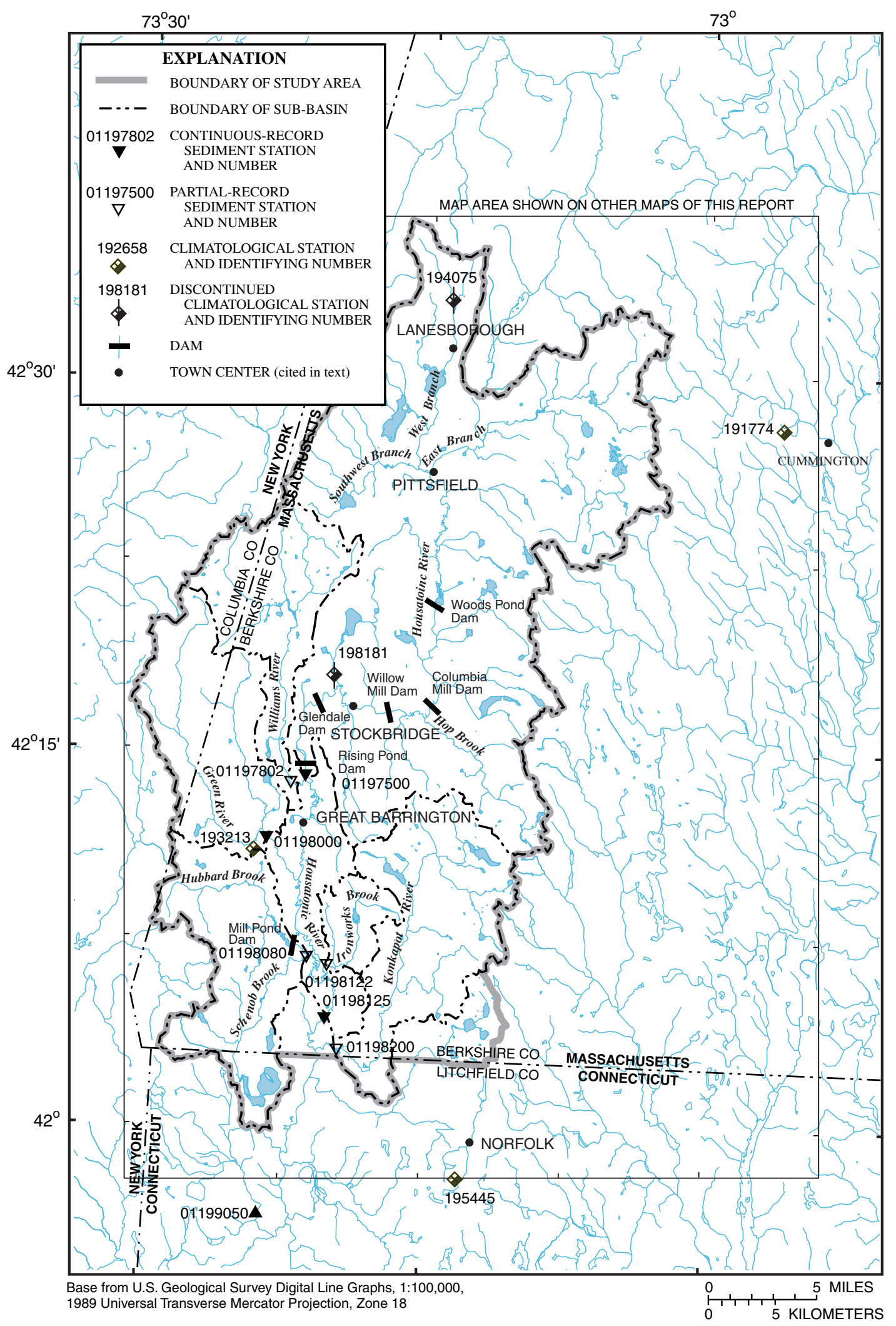

Figure 5. Climatological stations, dams, and continuous- and partial-record sediment stations in and near the Housatonic River Basin, western Massachusetts and parts of eastern New York and northwestern Connecticut. 
The Lanesborough climatological station, at an elevation of 1,240 ft above sea level, had lower mean temperatures and higher mean precipitation than the stations at Great Barrington Airport and Stockbridge, which are at elevations of 730 and $860 \mathrm{ft}$ above sea level, respectively. Low mean temperatures and high mean precipitation have been recorded at two highelevation NOAA climatological stations near the study area (fig. 5), Cummington Hill, Mass. (station 191774, elevation of 1,610 ft above sea level), and Norfolk 2

SW, Conn. (station 195445, elevation of 1,340 ft above sea level). Climatological records for 1961-90 at these two stations indicate that the mean annual temperature was 44.4 and $44.1^{\circ} \mathrm{F}$, and the mean annual precipitation was 46.0 and 51.5 in., respectively. Thus, temperatures generally decrease and precipitation generally increases with elevation.

\section{Hydrology}

The Housatonic River is formed by the confluence of the East Branch Housatonic River and the West Branch Housatonic River at Pittsfield, Mass. From the headwaters to the streamflow-gaging station (01197500) Housatonic River near Great Barrington, Mass. (fig. 5), the Housatonic River flows $49.7 \mathrm{mi}$; its mean channel slope is $16.5 \mathrm{ft} / \mathrm{mi}$ (Wandle and Lippert, 1984, p. 19). The drainage area upstream from the streamflow-gaging station near Great Barrington is $282 \mathrm{mi}^{2}$. The Housatonic River from Pittsfield to the streamflow-gaging station near Great Barrington (fig. 5) has five large dams (Woods Pond, Columbia Mill, Willow Mill, Glendale, and Rising Pond) and two smaller dams (Bickford and Dymon, 1990, p. 35; General Electric Company, 1991). Between the streamflow-gaging station at the Housatonic River near Great Barrington and the Massachusetts-Connecticut border (fig. 5), the Housatonic River is about $21 \mathrm{mi}$ long, has no dams, and has a mean channel slope of about $2 \mathrm{ft} / \mathrm{mi}$. The drainage area from the streamflowgaging station at the Housatonic River near Great Barrington to the Massachusetts-Connecticut border is $253 \mathrm{mi}^{2}$. Another 5-square-mile drainage area within Massachusetts drains into Connecticut and discharges into the Housatonic River downstream of the Massachusetts-Connecticut border.

Tributaries draining basins larger than $20 \mathrm{mi}^{2}$ in the study area are the East Branch Housatonic River, West Branch Housatonic River, Southwest Branch
Housatonic River, Hop Brook, Williams River, Green River, Schenob Brook, Hubbard Brook, and Konkapot River (fig. 5). The only subbasin in the basin in which streamflows are substantially altered from natural streamflow conditions is the East Branch Housatonic River, where water from reservoirs in the subbasin is transferred to an adjacent subbasin for use by the city of Pittsfield and other communities. Streamflow in the Housatonic River is affected by regulation on the East Branch Housatonic River and by the five large dams that use water for hydroelectric power and paper-mill processes. Additional detailed information on surfaceand ground-water characteristics in the Housatonic River Basin can be found in Norvitch (1966), Norvitch and Lamb (1966), Norvitch and others (1968), Wandle and Lippert (1984), and Bent (1999).

\section{CLIMATIC AND HYDROLOGIC CONDITIONS DURING THE STUDY PERIOD}

During the 2-year study (April 1994 through March 1996), average precipitation was $42.5 \mathrm{in} / \mathrm{yr}$ at the Great Barrington Airport (station 193213) (fig. 5), which was $2.3 \mathrm{in} / \mathrm{yr}$ below normal. From April through September 1994, precipitation was 23.2 in., which was 1.5 in. below normal; from October 1994 through September 1995, precipitation was 29.4 in., which was 15.4 in. below normal; and from October 1995 through March 1996, precipitation was 32.4 in., which was 12.3 in. above normal. By comparison, average precipitation was $52.0 \mathrm{in} / \mathrm{yr}$ at Norfolk $2 \mathrm{SW}$, Conn. (station 195445) (fig. 5), which was $0.5 \mathrm{in} / \mathrm{yr}$ above normal, during the 2-year study. From April through September 1994, precipitation was 29.4 in., which was 2.9 in. above normal; from October 1994 through September 1995, precipitation was 38.1 in., which was 13.4 in. below normal; and from October 1995 through March 1996, precipitation was 36.4 in., which was $11.5 \mathrm{in}$. above normal. The 6 months from October 1995 through March 1996 had about the same precipitation as the preceding 12 months at both climatological stations. This above-normal precipitation resulted from rain and snow that produced 9.8 and 9.6 in. of precipitation at Great Barrington Airport and 11.1 and $9.5 \mathrm{in}$. of precipitation at Norfolk 2 SW during October 1995 and January 1996, respectively. These 2 months accounted for about 23 percent of the total precipitation at Great 
Barrington Airport and 20 percent at Norfolk 2 SW during the 2-year study. Monthly precipitation during the 2-year study at Great Barrington Airport was similar to normal monthly precipitation 1961-90, except during October 1994 and May to August 1995 when it was about half of the normal and during October 1995 and January 1996 when it was about 3 times higher than normal (fig. 6).
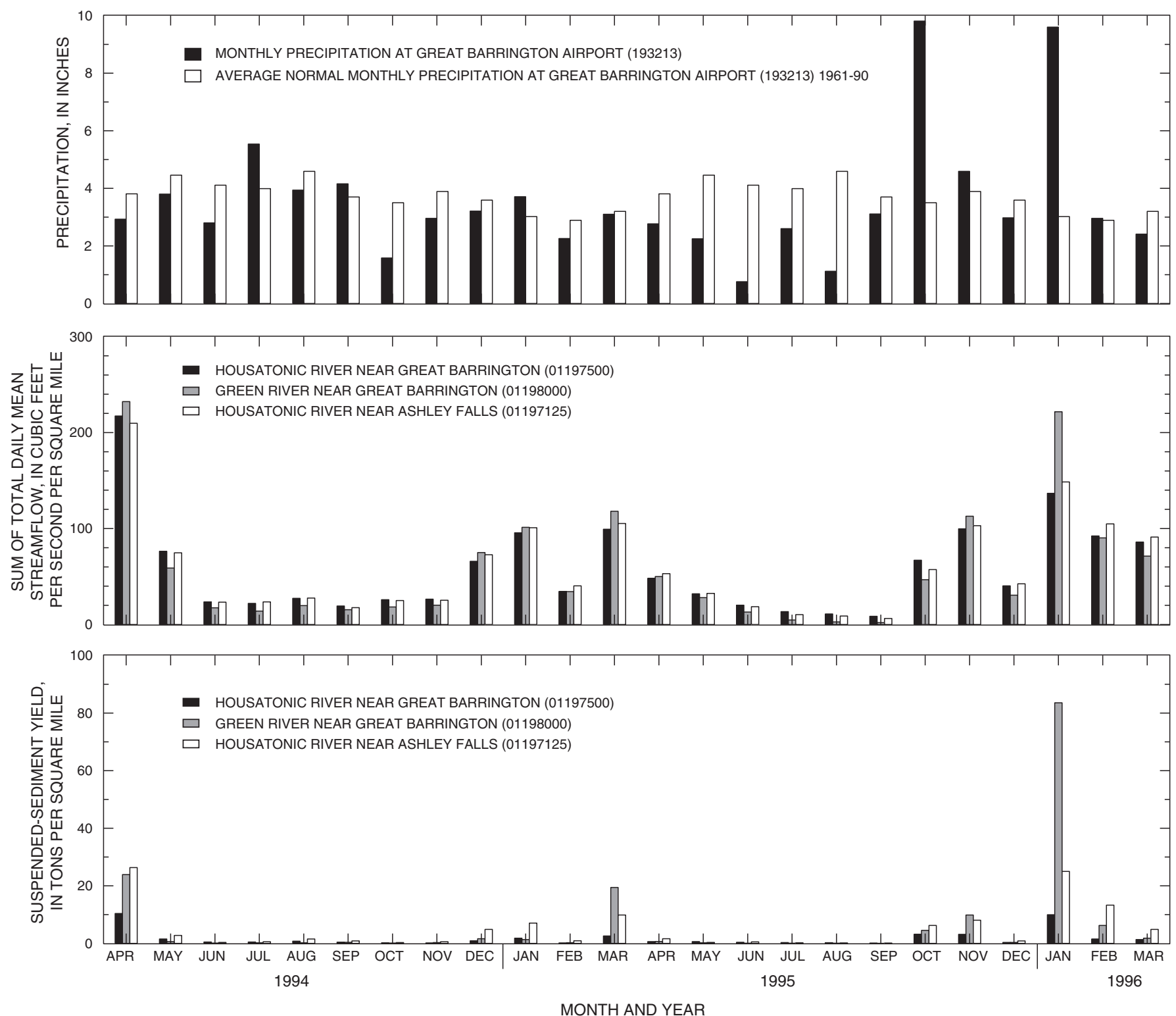

Figure 6. Monthly precipitation at the Great Barrington Airport climatological station and streamflow and suspended-sediment yield at the three continuous-record sediment stations in the Housatonic River Basin, western Massachusetts, April 1994 through March 1996. 
Flow-duration curves based on daily mean streamflow per square mile for six of the seven sediment stations from April 1994 through March 1996 are shown in figure 7. Flow-durations curves represent the percentage of time streamflow was equalled or exceeded during a selected period of time (Searcy, 1959). At flow durations less than 1 percent, the Green River (station 01198000) had higher streamflows per square mile than the other stations. At flow durations greater than 1 percent, Ironworks Brook (station 01198122) had lower streamflows per square mile than the other stations. At flow durations greater than 40 percent, the Housatonic River near Great Barrington (station 01197500), the Housatonic River near Ashley Falls (station 01198125), and the Konkapot River (station 01198200) had similar streamflows per square mile that were greater than streamflows per square mile at Williams River (station 01197802) and Green River, which were similar.

Two of the three continuous-record sediment stations have been operated as continuous streamflowgaging stations for more than 20 water years ${ }^{1}$ (table 2 ). Streamflows for the 2-year study (April 1994 through March 1996) were compared to long-term streamflows in the study area using flow-duration curves at the Housatonic River near Great Barrington (station 01197500) and the Green River (station 01198000) (fig. 8). Streamflows at flow durations less than 15 percent were greater during the 2-year study than during the long-term period of record for each of the stations. Streamflows at flow durations between 15 and 70 percent were similar at the Housatonic River near Great Barrington for the two periods of record but were lower at flow durations greater than 70 percent during April 1994 through March 1996 than during the long-term period. Streamflows at flow durations greater than 15 percent were generally greater during April 1994 through March 1996 at
Green River than during the long-term period of record, except at flow durations greater than about 90 percent.

The three continuous-record sediment stations [Housatonic River near Great Barrington (01197500), Green River (01198000), and Housatonic River near Ashley Falls (01198125)] had similar monthly streamflow per square mile except during January 1996 (fig. 6). Green River had about 62 and 50 percent greater streamflow per square mile than the Housatonic River near Great Barrington and the Housatonic River near Ashley Falls, respectively during January 1996. The reason for this different response is believed to be that the Green River subbasin had a greater rainfall-snowmelt runoff than in other parts of the Housatonic River Basin on January 19 and 20, 1996. The instantaneous peak streamflow for this rainfall-snowmelt runoff at Green River was $6,490 \mathrm{ft}^{3} / \mathrm{s}$, which was three times greater than the previous instantaneous peak streamflow of $2,120 \mathrm{ft}^{3} / \mathrm{s}$ recorded during 21 years of continuous streamflow records (1952-71 and 1994-95). The peak streamflow for this rainfallsnowmelt runoff at the Housatonic River near Great Barrington station was the equivalent of a 2to 5-year runoff recurrence interval. Additionally, precipitation on January 19 and 20, 1996 at Great Barrington Airport (station 193213) was 2.0 in. and the snow depth was reduced from 42 to 6 in.- the equivalent of 5 to 6 in. of rainfall in the Green River subbasin, whereas precipitation at Norfolk $2 \mathrm{SW}$, Conn. (station 195445) (fig. 5), on these dates was 2.2 in. and the snow depth was reduced from 28 to 14 in. - the equivalent of 3 to $4 \mathrm{in}$. of rainfall in this area. This difference indicates that the rainfall equivalent (actual rainfall plus snowmelt) may have been greater in the Green River subbasin than in other parts of the Housatonic River Basin.

\footnotetext{
${ }^{1}$ A water year is the 12-month period beginning October 1 and ending September 30. It is designated by the calendar year in which it ends.
} 


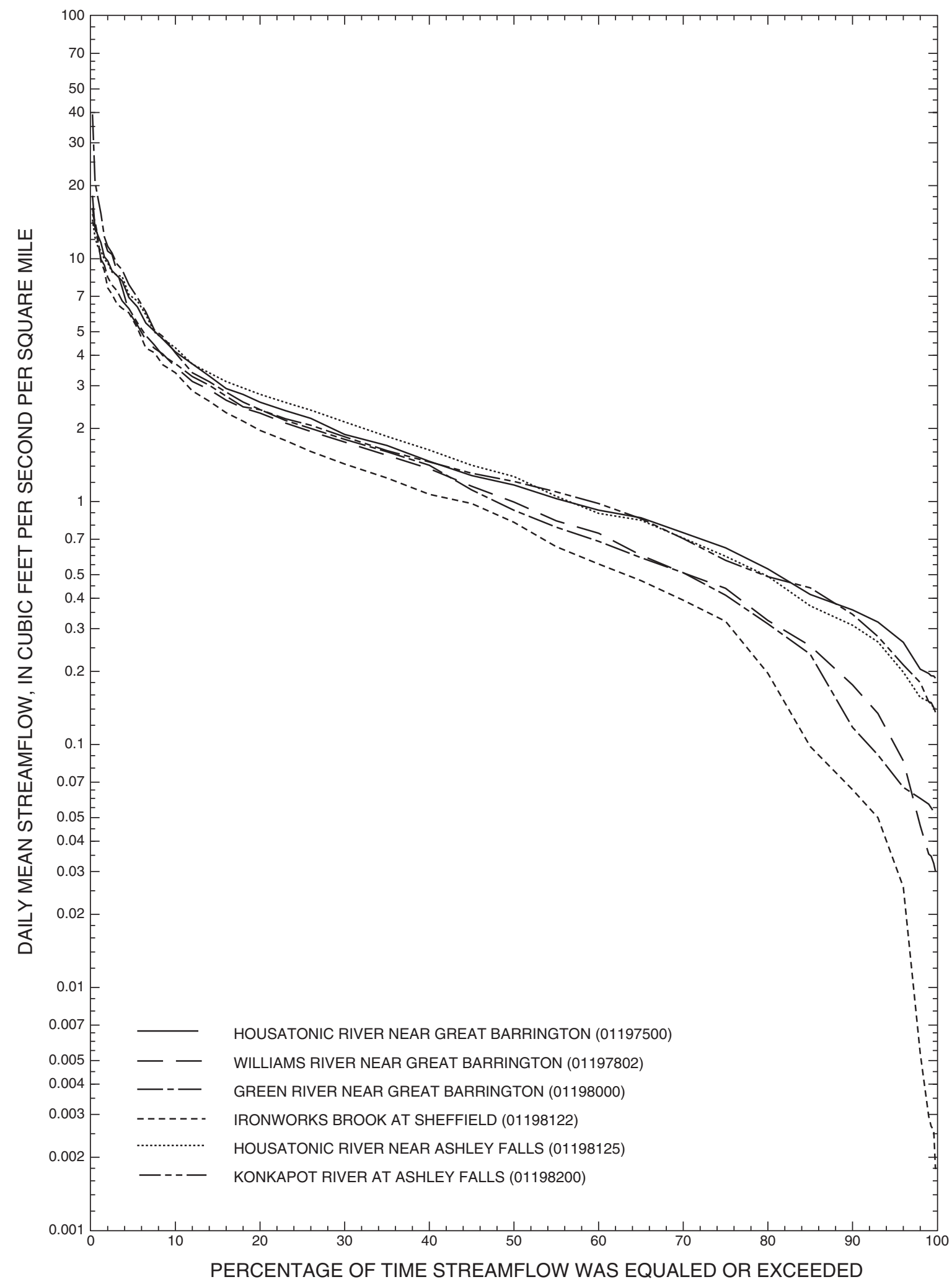

Figure 7. Flow-duration curves of daily mean streamflow per square mile at sediment stations in the Housatonic River Basin, western Massachusetts, April 1994 through March 1996. 
Table 2. Description of continuous- and partial-record sediment stations in the Housatonic River Basin, western Massachusetts

[USGS station No.: Locations shown in figure 5. Latitude and longitude are given in degrees, minutes, seconds. Water years: A water year is the 12-month period beginning October 1 and ending September 30. It is designated by the calendar year in which it ends. No., number; USGS, U.S. Geological Survey; $\mathrm{ft}$, foot; mi, mile; $\mathrm{mi}^{2}$, square mile; --, no remarks]

$\begin{array}{ccccccc}\begin{array}{c}\text { USGS } \\ \text { station } \\ \text { No. }\end{array} & \begin{array}{c}\text { Station name } \\ \text { and location }\end{array} & \text { Latitude } & \text { Longitude } & \begin{array}{c}\text { Period of } \\ \text { streamflow } \\ \text { record } \\ \text { (water years) }\end{array} & \begin{array}{c}\text { Period of } \\ \text { suspended- } \\ \text { sediment } \\ \text { sampling } \\ \text { (water years) }\end{array} & \begin{array}{c}\text { Drainage } \\ \left(\mathrm{mi}^{2}\right)\end{array} \\ \end{array}$

Continuous-Record Sediment Stations

\begin{tabular}{|c|c|c|c|c|c|c|c|}
\hline 01197500 & $\begin{array}{l}\text { Housatonic River near Great } \\
\text { Barrington at bridge on } \\
\text { Division Street }\end{array}$ & 421355 & 732119 & $\begin{array}{l}\text { 1914- } \\
\text { present }\end{array}$ & $\begin{array}{l}1979-80 \\
1984, \\
1986-88, \\
1994-96\end{array}$ & 282 & $\begin{array}{l}\text { Regulation at low flow by } \\
\text { powerplants upstream; } \\
\text { high flows slightly affected } \\
\text { by retarding reservoir since } \\
1973\end{array}$ \\
\hline 01198000 & $\begin{array}{l}\text { Green River near Great } \\
\text { Barrington at bridge on } \\
\text { Hurlburt Road }\end{array}$ & 421131 & 732328 & $\begin{array}{l}\text { 1952-71, } \\
1994-96\end{array}$ & $\begin{array}{l}\text { 1967-71, } \\
1994-96\end{array}$ & 51.0 & -- \\
\hline 01198125 & $\begin{array}{l}\text { Housatonic River near Ashley } \\
\text { Falls at bridge on U.S. } \\
\text { Highway } 7\end{array}$ & 420429 & 732003 & 1994-96 & 1994-96 & 465 & -- \\
\hline \multicolumn{8}{|c|}{ Partial-Record Sediment Stations } \\
\hline $01197802^{1}$ & $\begin{array}{l}\text { Williams River near Great } \\
\text { Barrington at railroad } \\
\text { bridge } 200 \mathrm{ft} \text { south of } \\
\text { Division Street }\end{array}$ & 421339 & 732146 & 1994-96 & 1994-96 & 43.2 & -- \\
\hline $01198080^{1}$ & $\begin{array}{c}\text { Schenob Brook at Sheffield at } \\
\text { bridge on U.S. Highway } 7\end{array}$ & 420651 & 732105 & 1994-95 & 1994-95 & 50.0 & $\begin{array}{l}\text { Affected by backwater from } \\
\text { the Housatonic River, } \\
0.25 \text { mi downstream, } \\
\text { during medium- to high- } \\
\text { flows }\end{array}$ \\
\hline 01198122 & $\begin{array}{l}\text { Ironworks Brook at Sheffield } \\
\text { at bridge on East Road }\end{array}$ & 420631 & 732008 & 1994-96 & 1994-96 & 11.2 & -- \\
\hline 01198200 & $\begin{array}{l}\text { Konkapot River at Ashley } \\
\text { Falls at bridge on U.S. } \\
\text { Highway } 7\end{array}$ & 420311 & 731935 & 1994-96 & 1994-96 & 61.1 & $\begin{array}{l}\text { Regulation during spring and } \\
\text { fall period upstream at } \\
\text { Lake Garfield }\end{array}$ \\
\hline
\end{tabular}

\footnotetext{
${ }^{1}$ No continuous streamflow-record published in Water-Resources Data Report Massachusetts and Rhode Island Water Year 1995 and 1996 (Socolow and others, 1996, 1997).
} 


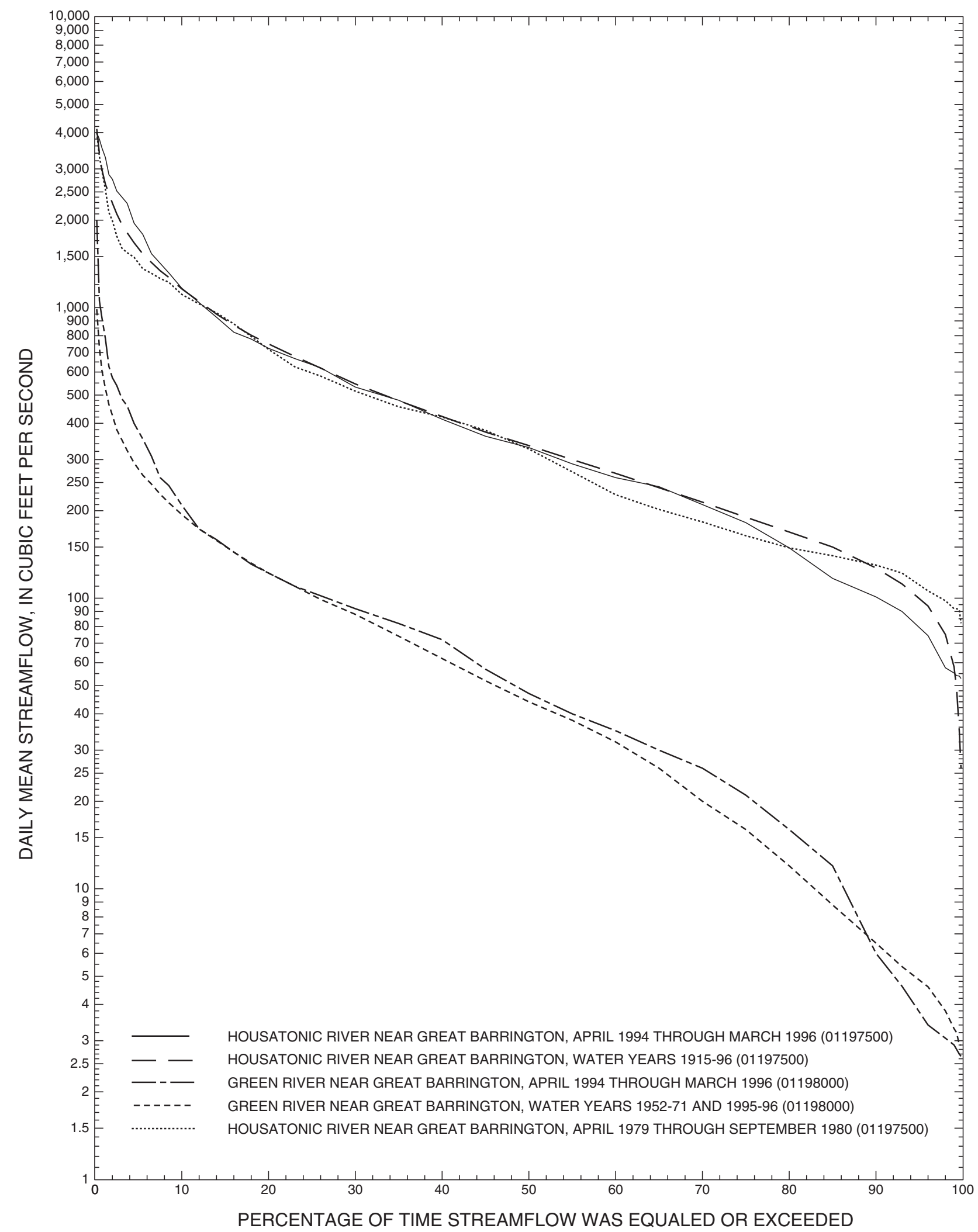

Figure 8. Flow-duration curves of daily mean streamflow during selected periods at sediment stations at the Housatonic River near Great Barrington and Green River near Great Barrington, Mass. 


\section{DATA COLLECTION AND ANALYSIS}

Three continuous-record and four partial-record sediment stations used for this investigation are shown in figure 5 and described in table 2. Daily values of mean streamflow, mean suspended-sediment concentration, and suspended-sediment discharge (based on suspended-sediment samples collected once every 3 to 7 days and at least once per day during moderate to high runoff) are calculated for the continuous-record sediment stations. Instantaneous values of streamflow, suspended-sediment concentration, and suspended-sediment discharge (based on suspended-sediment samples collected once every 1 to 2 months and at least once per day during moderate to high runoff) are available for the partialrecord sediment stations. The partial-record sediment stations in this study did not have a continuous record of streamflow. Streamflow records at these stations were based on one gage-height reading per day during stable flow. During moderate to high runoff, which typically lasts 1 to 3 days, one to two additional gageheight readings per day were made concurrently with the collection of suspended-sediment samples at the partial-record stations. These stations also were equipped with crest-stage gages to determine the peak streamflow during high flows. Collection of streamflow data and computation of the streamflow records followed the standard procedures recommended by Rantz and others (1982, p. 24-25 and 559-560) for nonrecording (no continuous record of gage height) gaging stations. In addition, gage-height readings for these stations were plotted concurrently with the continuous-gage heights at two nearby continuousrecord stations [Green River near Great Barrington (01198000) and Salmon Creek at Lime Rock, Conn. (01199050)] to help determine the beginning of runoff as well as provide information on the timing of the runoff peaks and recessions.

\section{Collection of Samples for Suspended-Sediment Concentration}

Samples for analysis of suspended-sediment concentration were collected during late March 1994 through early April 1996 at three continuous-record and four partial-record sediment stations (fig. 5 and table 2). The methods used were (1) multivertical depth-integrated samples using equal-width increments (EWI) or equal-discharge increments (EDI), (2) single vertical depth-integrated samples from a fixed location (box sample), or (3) both (Edwards and Glysson, 1999, p. 38-51). The sampling devices used were the DH-48 (used when wading streams), the DH-59 (used for sampling from bridges when stream velocities were estimated to be less than $5.0 \mathrm{ft} / \mathrm{s}$ ), and the D-74 (used for sampling from bridges when velocities were estimated to be greater than $5.0 \mathrm{ft} / \mathrm{s})($ Edwards and Glysson, 1999, p. 6-11). Information collected with each sample were date, time, stream stage (gage height), water temperature, air temperature, person(s) sampling, sampler type, nozzle size, stream depth, sampling method, number of sampling locations across stream, number of bottles, important remarks about stream conditions (such as backwater or ice), distance from the streambank of the sampling locations, and other pertinent information (U.S. Geological Survey, 1991). The quality-assurance procedures described in Knott and others (1993), were followed for the collection of suspended-sediment samples.

Samples were collected during March through September 1994 by USGS personnel. During October 1995 through April 1996, routine samples and runoff samples were collected by trained local observers and USGS personnel. Local observers generally sampled using the single vertical depth-integrated method from a fixed location (box sample). Local observer sampling techniques were checked periodically with duplicate samples and (or) concurrent sampling by USGS personnel. Duplicate samples were collected about 20 to 25 percent of the time, especially during high streamflows when substantial variability in suspendedsediment concentrations would be expected.

Suspended-sediment samples were analyzed for concentration in milligrams per liter, particle sizes coarser or equal to $0.062 \mathrm{~mm}$ diameter (sand), and particle sizes finer than $0.062 \mathrm{~mm}$ diameter (silt and clay). Particle sizes were analyzed on about 22 percent of the suspended-sediment samples collected, especially during high streamflows when more sand may be transported than during low to medium streamflows. In some cases these analyses were used to compare samples for possible errors in sampling techniques. The reporting limit for suspended-sediment concentration analysis is $0.5 \mathrm{mg} / \mathrm{L}$; concentrations reported less than this limit should be considered estimates of the true values. Samples collected during March and April 1994 were analyzed at the USGS 
Sediment Laboratory in Lemoyne, Pa., and samples collected from May 1994 through April 1996 were analyzed at the USGS Sediment Laboratory in Louisville, Ky. Both USGS Sediment Laboratories follow USGS protocols for analysis of suspended-sediment concentration and particle size, as described in Matthes and others (1991) and Knott and others (1992).

Samples were collected to ensure that the entire range of streamflows were sampled during rising and falling stream stages. The three continuous-record sediment stations were equipped with box samplers, so that single vertical depth-integrated samples from a fixed location could be taken. To determine whether a cross-section coefficient needed to be applied to the suspended-sediment concentration of each box sample so that it represented the mean suspended-sediment concentration of the stream (Porterfield, 1972, p. 1117), periodic EWI or EDI samples were collected concurrently with box samples from March 1994 through April 1996.

At partial-record sediment stations, samples were collected periodically during stable stream stages (generally at least monthly) and about daily during high runoff from March 1994 through April 1996. Most samples were collected during the rising and falling stream stages of high runoff. Additionally, attempts were made to sample the entire range of streamflow. Schenob Brook at Sheffield (station 01198080) was only sampled seven times from March 1994 through April 1996 because backwater occurred at the site during certain stages of runoff (generally medium to high streamflows) on the Housatonic River, which is less than $0.25 \mathrm{mi}$ downstream (fig. 5). These backwater conditions resulted in a poor relation between stream stage and streamflow and affected the relation between streamflow and suspended-sediment transport for Schenob Brook.

\section{Calculation of Suspended-Sediment Discharge, Load, and Yield}

To most accurately represent the mean suspended-sediment concentration of the stream (Porterfield, 1972, p. 11-17), it was necessary to determine if a cross-section coefficient needed to be applied to the sediment concentrations of the box samples collected from the three continuous-record stations (fig. 5 and table 2). The ratio of suspendedsediment concentrations from concurrent box samples to EWI or EDI samples was plotted against the date and time the samples were collected and the stream stage at the time of sampling to evaluate whether the ratios were different than 1.0 . If the ratios were different than 1.0 (lower or higher) over a specified sampling time period or at different stream stages, a cross-section coefficient would be applied to the suspended-sediment concentrations from box samples so that the mean suspended-sediment concentration of the stream (make the ratio equal to 1.0) was represented.

Daily total suspended-sediment discharge during stable-flow conditions was calculated by multiplying the daily mean suspended-sediment concentration in milligrams per liter by the concurrent daily mean streamflow in cubic feet per second, and then by the coefficient 0.0027 to convert the resulting units into tons per day (Porterfield, 1972, p. 43). Calculation of daily total suspended-sediment discharge during changing streamflows involves the summing of timeweighted suspended-sediment discharge over the day (Porterfield, 1972, p. 39-56). Days are subdivided into time intervals based on changes in streamflow or sediment concentration, or both. During runoff, when suspended-sediment samples collected were insufficient to define the change in suspended-sediment concentration, the following data were used to estimate the concentrations: (1) plots of the relation of suspended-sediment concentration to concurrent streamflow and associated sediment-transport curves; (2) concentrations of samples collected before and after the time needed to be estimated; and (3) concentrations during other similar runoff events. The USGS computer program SEDCALC (Koltun and others, 1994) was used to compute daily suspended-sediment discharges and daily mean suspended-sediment concentrations for this study.

Suspended-sediment discharge was estimated for three of the four partial-record sediment stations (fig. 5 and table 2) using sediment-transport curves and flowduration curves in a method often referred to as the flow-duration, rating-curve method (Crawford, 1991). The flow-duration, rating-curve method is described by Miller (1951), and examples of its use are given by Simmons (1993, p. 16-20). Because backwater conditions created a poor relation between stream stage and streamflow, and affected the relation between streamflow and suspended-sediment transport, suspended-sediment discharge could not be determined using the flow-duration, rating-curve method at Schenob Brook (station 01198080). 
Flow-duration curves could not be calculated initially at Williams River (station 01197802), Ironworks Brook (station 01198122), and Konkapot River (station 01198200) because continuous streamflow records (daily mean streamflows) did not exist for the entire period of April 1994 to March 1996 (Socolow and others, 1996, 1997). The period of continuous streamflow records (daily mean streamflows) during 1994-96 at Ironworks Brook and Konkapot River was based on once a day gage-height (stream-stage) readings. The non-continuous streamflow records at Ironworks Brook (April to July 1994) and Konkapot River (April to May 1994) were estimated based on miscellaneous gageheight readings and hydrograph comparison to the continuous streamflow records at the streamflow-gaging stations at Green River (01198000) and Salmon Creek at Lime Rock, Conn. (01199050) (about $3.5 \mathrm{mi}$ south of the study area shown in fig. 5). Continuous streamflow at Williams River during April 1994 through March 1996 was estimated based on miscellaneous gage-height readings (generally every couple of days) and on hydrograph comparison to Green River near Great Barrington and Salmon Creek at Lime Rock, Conn. After daily mean streamflows at the three stations were estimated for periods of missing data, flowduration curves were calculated for each station from April 1994 through March 1996. The daily mean streamflows used for the flow-duration curves for the three stations from April 1994 through March 1996 are listed in appendix 1 (at back of report).

Sediment-transport curves for Williams River (station 01197802), Ironworks Brook (station 01198122), and Konkapot River (station 01198200) were developed from instantaneous suspendedsediment discharge and instantaneous streamflow data (1994-96) using the general methods described by Glysson (1987). Sediment-transport curves developed for the three partial-record sediment stations on the Williams River, Ironworks Brook, and Konkapot River involved $\log$ transformation of the concurrent instantaneous suspended-sediment discharge and streamflow data. The LOWESS (LOcally WEighted Scatterplot Smoothing) statistical method (Cleveland, 1979), described by Helsel and Hirsch (1992, p. 286291), was used to determine the relation between concurrent instantaneous suspended-sediment discharge and streamflow data. The LOWESS statistical method determines a smooth (curved) line through the concurrent log-transformed data. Visual inspection of the LOWESS smooth line through the data was used to determine if a singular straight line or multiple straight lines would best fit the data. At Williams River, Ironworks Brook, and Konkapot River, it was determined that more than one straight line would best fit the data. Simple linear-regression models (Helsel and Hirsch, 1992, p. 221-264) were then applied to the straight-line segments of the concurrent log-transformed instantaneous suspended-sediment discharge and concurrent streamflow data. Farr and Clarke (1984), Ferguson (1986), and Koch and Smillie (1986) found that estimates of suspended-sediment using a rating curve (relation between suspendedsediment discharge as a function of streamflow) would be underestimated because of bias introduced during the retransformation of data. To retransform the simple-linear regression models (equations), a biascorrection factor had to be applied (U.S. Geological Survey, 1992). The bias-correction factor used was Duan's smearing method (Duan, 1983), and the sediment-transport curve equation is in the form of:

$$
\begin{aligned}
Q_{s} & =(\text { bias correction factor }) \\
& \times \exp \left(y \text {-intercept }+\operatorname{slope}\left(\ln Q_{w}\right)\right)
\end{aligned}
$$

where

$Q_{s}$ is the instantaneous suspended-sediment discharge, in ton/d;

exp is the base of the natural logarithm (approximately exp=2.718); and

$\ln Q_{w}$ is the natural logarithm of streamflow, in $\mathrm{ft}^{3} / \mathrm{s}$.

Suspended-sediment discharges for specified flowduration increments are then calculated by inputting the streamflow of the mid-points of the flow-duration increments into sediment-transport curve equations (Miller, 1951).

Suspended-sediment loads at the three continuous-record sediment stations were calculated by summing the total daily suspended-sediment discharge for a defined period of time (for example, monthly, year, or for the 2-year study) to obtain tons. Suspended-sediment loads at the three partial-record sediment stations were calculated by summing all the suspended-sediment discharge multiplied by their corresponding flow-duration increments to obtain tons for the 2-year study.

Suspended-sediment yield (suspended-sediment load per unit of contributing drainage area) at the three continuous-record and three partial-record sediment stations was calculated in two steps. First, 
suspended-sediment load from April 1994 through March 1996 at each station was divided by the 2-year period of record to obtain tons per year. Second, each value was then divided by its respective subbasin drainage area in square miles to obtain suspendedsediment yield in tons per year per square mile. Suspended-sediment yield can also be expressed in other units of time, such as tons per day per square mile.

\section{SUSPENDED-SEDIMENT CHARACTERISTICS IN THE HOUSATONIC RIVER BASIN}

Analysis of suspended-sediment data involved evaluation of suspended-sediment concentrations of the samples collected and evaluation of calculated suspended-sediment disharges, loads, and yields. The concentration section focuses mainly on the range of suspended-sediment concentrations and the relation of suspended-sediment concentration to streamflow. The discharge section focuses mainly on sediment-transport equations and curves and calculation of suspendedsediment discharge at the three partial-record sediment stations. The load section focuses mainly on the percentage of the total suspended-sediment loads for the basin from individual subbasins and the percentage of time and hydrological events during which most suspended-sediment loads are transported. The yield section focuses mainly on the comparison of yields among the subbasins and estimation of yields for two ungaged subbasins.

\section{Concentration}

Results of suspended-sediment concentration analyses for all samples collected from March 1994 through April 1996 at the seven sediment stations are shown in appendix 2 (at back of report), along with data on particle size, streamflow, water temperature, air temperature, and specific conductance at the time of sample collection. Suspended-sediment concentration samples were collected close to the time of minimum and maximum (peak) instantaneous streamflows at the continuous-record and partial-record sediment stations (table 3). The maximum instantaneous streamflow at which suspended-sediment concentrations were measured at Ironworks Brook was about 17 percent lower than the recorded peak instantaneous streamflow.

The difference at this site between maximum streamflow sampled and peak streamflow recorded was the largest among the seven stations. Collection of samples close to the time of peak streamflows, as well

Table 3. Minimum and maximum instantaneous streamflows recorded and minimum and maximum instantaneous streamflows sampled for suspended-sediment concentration at continuous- and partial-record sediment stations in the Housatonic River Basin, western Massachusetts, March 1994 through April 1996

[USGS station No.: Locations shown in figure 5 and described in table 2. No., number; USGS, U.S. Geological Survey; $\mathrm{ft}^{3} / \mathrm{s}$, cubic foot per second; $\mathrm{mi}^{2}$, square mile]

\begin{tabular}{|c|c|c|c|c|c|c|}
\hline $\begin{array}{c}\text { USGS } \\
\text { station } \\
\text { No. }\end{array}$ & Station name & $\begin{array}{c}\text { Drainage } \\
\text { area } \\
\left(\mathbf{m i}^{2}\right)\end{array}$ & $\begin{array}{l}\text { Minimum } \\
\text { instantaneous } \\
\text { streamflow } \\
\text { recorded } \\
\left(\mathrm{ft}^{3} / \mathrm{s}\right)\end{array}$ & $\begin{array}{c}\text { Minimum } \\
\text { instantaneous } \\
\text { streamflow } \\
\text { sampled } \\
\left(\mathrm{ft}^{3} / \mathrm{s}\right)\end{array}$ & $\begin{array}{l}\text { Maximum } \\
\text { instantaneous } \\
\text { streamflow } \\
\text { recorded } \\
\left(\mathrm{ft}^{3} / \mathrm{s}\right)\end{array}$ & $\begin{array}{c}\text { Maximum } \\
\text { instantaneous } \\
\text { streamflow } \\
\text { sampled } \\
\left(\mathrm{ft}^{3} / \mathrm{s}\right)\end{array}$ \\
\hline 01197500 & $\begin{array}{l}\text { Housatonic River near Great Barrington, } \\
\text { Mass. }\end{array}$ & 282 & 11 & 60 & 4,430 & 4,160 \\
\hline $01197802^{1,2}$ & Williams River near Great Barrington, Mass. & 43.2 & 0.10 & 1.2 & 900 & 900 \\
\hline 01198000 & Green River near Great Barrington, Mass. & 51.0 & 2.2 & 2.8 & 6,490 & 6,440 \\
\hline $01198080^{3,4}$ & Schenob Brook at Sheffield, Mass. & 50.0 & 2.2 & 8.9 & 480 & 480 \\
\hline $01198122^{1,2}$ & Ironworks Brook at Sheffield, Mass. & 11.2 & .02 & .73 & 483 & 402 \\
\hline 01198125 & Housatonic River near Ashley Falls, Mass. & 465 & 65 & 67 & 7,110 & 7,030 \\
\hline $01198200^{1,2}$ & Konkapot River at Ashley Falls, Mass. & 61.1 & 8.3 & 9.1 & 1,280 & 1,230 \\
\hline
\end{tabular}

\footnotetext{
${ }^{1}$ No continuous stage monitoring. Streamflow based on once a day stage readings.

${ }^{2}$ Crest-stage gage operated to estimate peak streamflows.

${ }^{3}$ No continuous stage monitoring. Streamflow based on occasional stage readings.

${ }^{4}$ No crest-stage operated due to backwater conditions.
} 
as during the rising and falling of streamflows to and from the peak, are important because most suspended sediment is transported during high streamflows.

The number of suspended-sediment samples collected and the minimum, maximum, and median instantaneous suspended-sediment concentration at the seven sediment stations in the Housatonic River Basin during the study period as listed in table 4. Median instantaneous streamflows per square mile during suspended-sediment sampling were somewhat similar at Housatonic River near Great Barrington (station 01197500), Williams River (station 01197802), Green River (station 01198000), and Housatonic River near Ashley Falls (station 01198125) (table 4). Median instantaneous streamflows per square mile during suspended-sediment sampling at Ironworks Brook (station 01198122) and Konkapot River (station 01198200) were at least twice that of other sediment stations except Schenob Brook (station 01198080). These higher median instantaneous streamflows per square mile are a reason why the median suspendedsediment concentrations at Ironworks Brook and Konkapot River were at least three times greater than those at the other sediment stations. Median suspended-sediment concentrations at Housatonic River near Great Barrington, Williams River, and Green River were fairly similar, but they were about half of the median suspended-sediment concentration at Housatonic River near Ashley Falls.

The relation of instantaneous suspendedsediment concentration to concurrent streamflow and the associated sediment-transport curves at six sediment stations is shown in figure 9. Note, the first segment of the sediment-transport curve at low flows for Ironworks Brook (station 01198122) has a slightly negative slope due to the low number of samples collected between streamflows of about 0.7 and $15 \mathrm{ft}^{3} / \mathrm{s}$. In reality, this first segment of the sediment-transport curve at low streamflows would have a slightly positive slope, such as the other five sediment stations exhibit when sampled sufficiently. These plots and curves were sometimes used in conjunction with other methods (previously discussed in the "Calculation of Suspended-Sediment Discharge, Load, and Yield" section) to estimate suspendedsediment concentrations at the three continuous-record sediment stations during periods of no data. The plots show a great amount of variability in suspendedsediment concentration at the same streamflows. For example, at Green River (station 01198000), the suspended-sediment concentrations at a streamflow of $200 \mathrm{ft}^{3} / \mathrm{s}$ ranged from 1 to $60 \mathrm{mg} / \mathrm{L}$, and at Housatonic River near Ashley Falls (station 01198125) the suspended-sediment concentrations at a streamflow of $1,000 \mathrm{ft}^{3} / \mathrm{s}$ ranged from about 5 to $50 \mathrm{mg} / \mathrm{L}$.

The percentage of suspended-sediment particles finer than $0.062 \mathrm{~mm}$ (clay and silt size particles) in the suspended-sediment samples ranged from 30 to 94, 42 to 100, and 33 to 100 percent at Housatonic River near Great Barrington (station 01197500), Green River (station 01198000), and Housatonic River near Ashley Falls (station 01198125), respectively and from 29 to 80, 45 to 92,15 to 59 , and 4 to 93 percent at Williams River (station 011987802), Schenob Brook (station 01198080), Ironworks Brook (station 01198122), and Konkapot River (station 01198200), respectively (appendix 2 at back of report). Generally, lower percentages of clay and silt were transported during high streamflows than during medium to low streamflows, and more sand was transported during high streamflows. The lower maximum percentage of suspended-sediment particles finer than $0.062 \mathrm{~mm}$ at Williams River and Ironworks Brook and higher minimum percentage at Schenob Brook compared to the other sediment station is likely due to the much lower number of times those stations were sampled for particle size. The low minimum percentage of suspended-sediment particles finer than $0.062 \mathrm{~mm}$ at Konkapot River is the result of samples collected during streambed degradation of approximately $1.5 \mathrm{ft}$ from high runoff on October 28, 1995.

Box samples taken for suspended-sediment concentration were evaluated to determine if crosssection coefficients needed to be applied to make the samples represent the mean suspended-sediment concentration of the stream. The ratio of the concurrent box sample suspended-sediment concentrations to the EWI or EDI sample concentrations was fairly close to 1.0 over time and for changing stream stages, so no cross-section coefficient was applied to the box samples from the Green River (station 01198000) or the Housatonic River near Ashley Falls (station 01198125). Only three concurrent samples were taken at the Housatonic River near Great Barrington (station 01197500) because of limiting factors that involved sampling from the bridge. Because the need of a crosssection coefficient at this site could not be evaluated with these limited data, no cross-section coefficient was applied to these box samples either. 


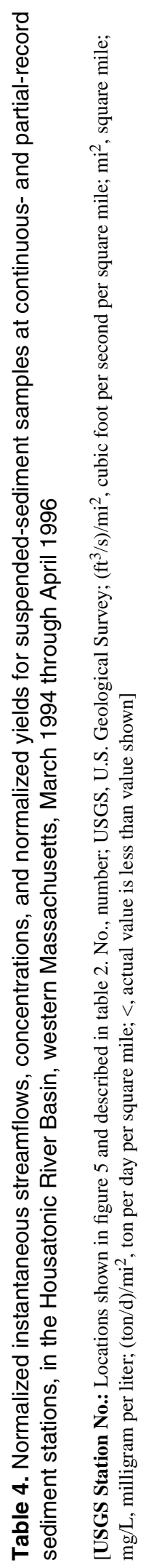

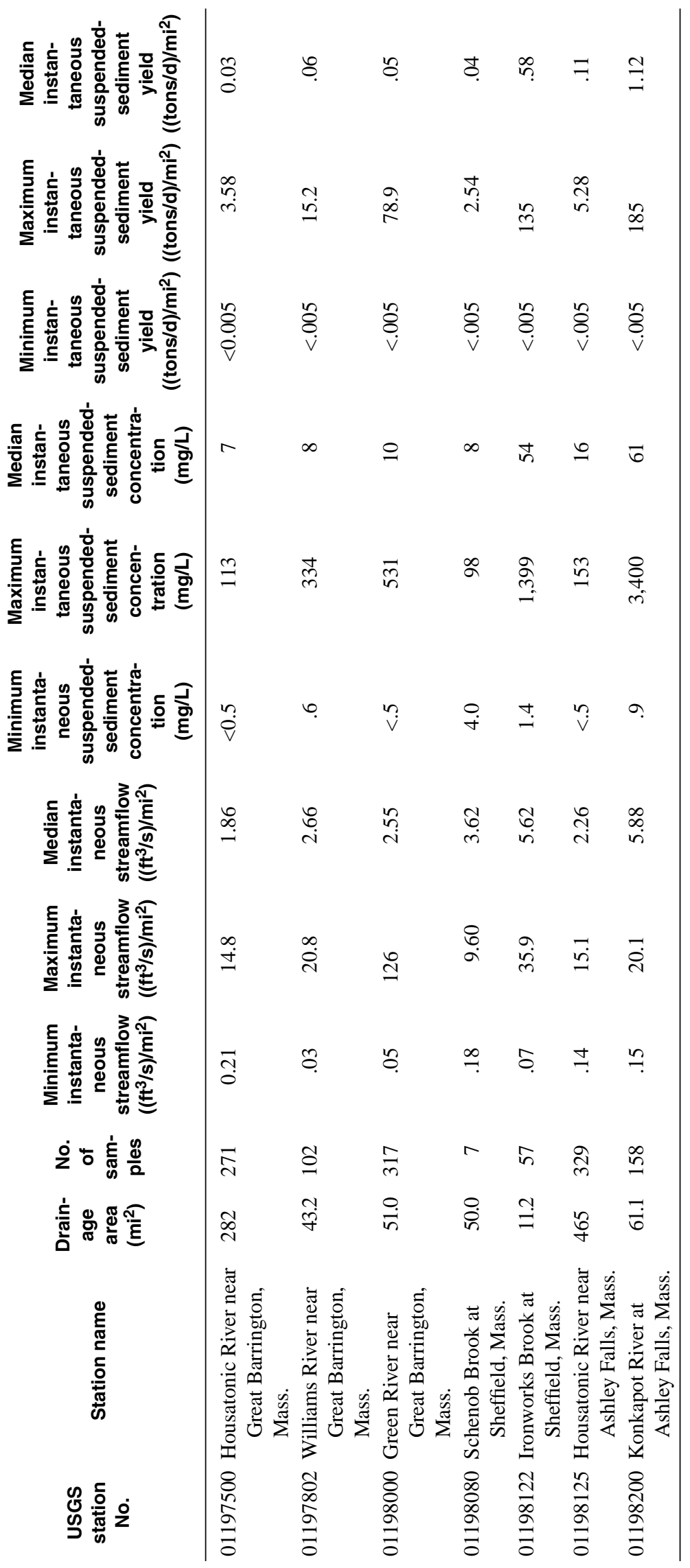




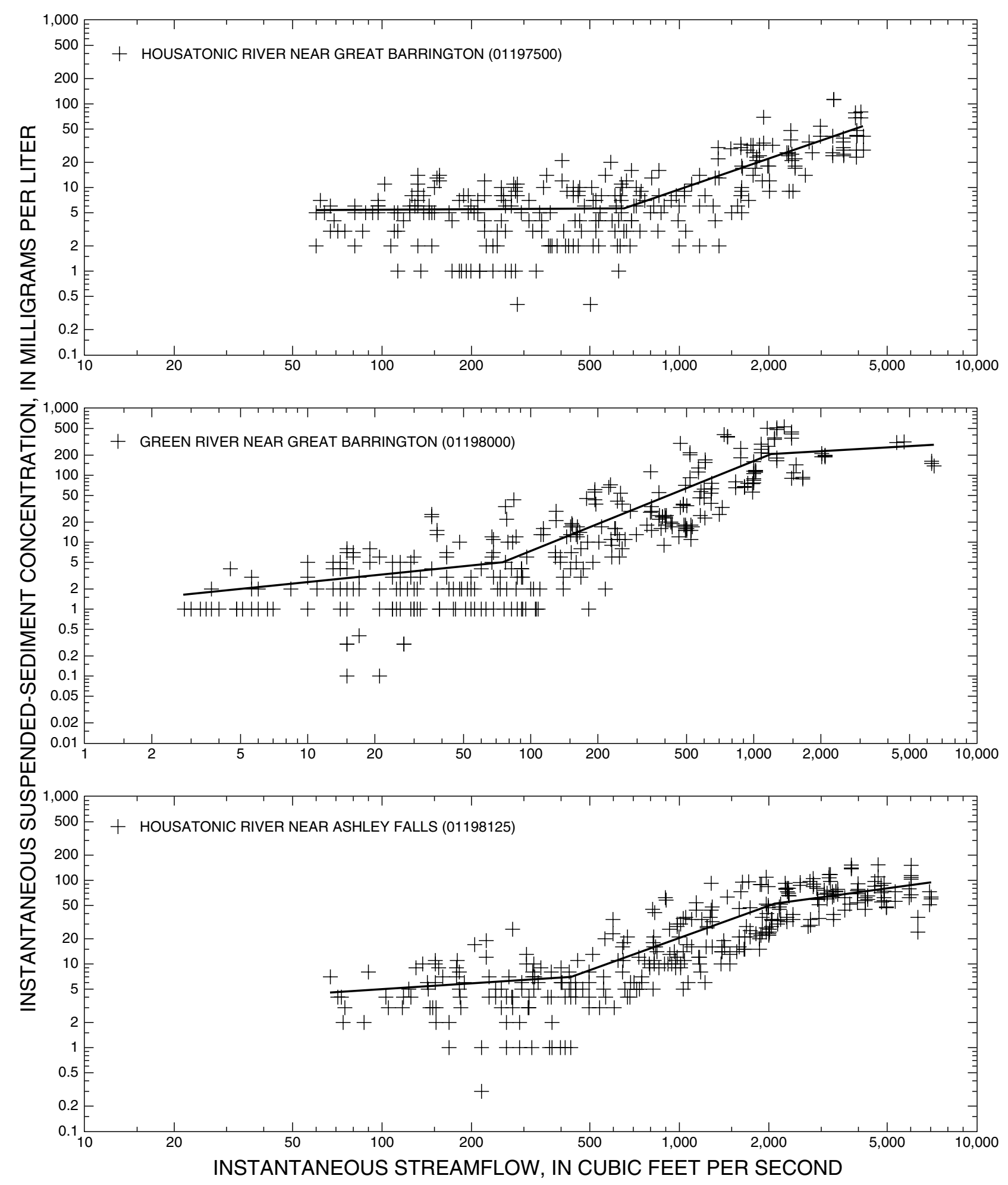

Figure 9. Relation of instantaneous suspended-sediment concentration to concurrent streamflow and associated sediment-transport curves at six sediment stations in the Housatonic River Basin, western Massachusetts, March 1994 through April 1996. 

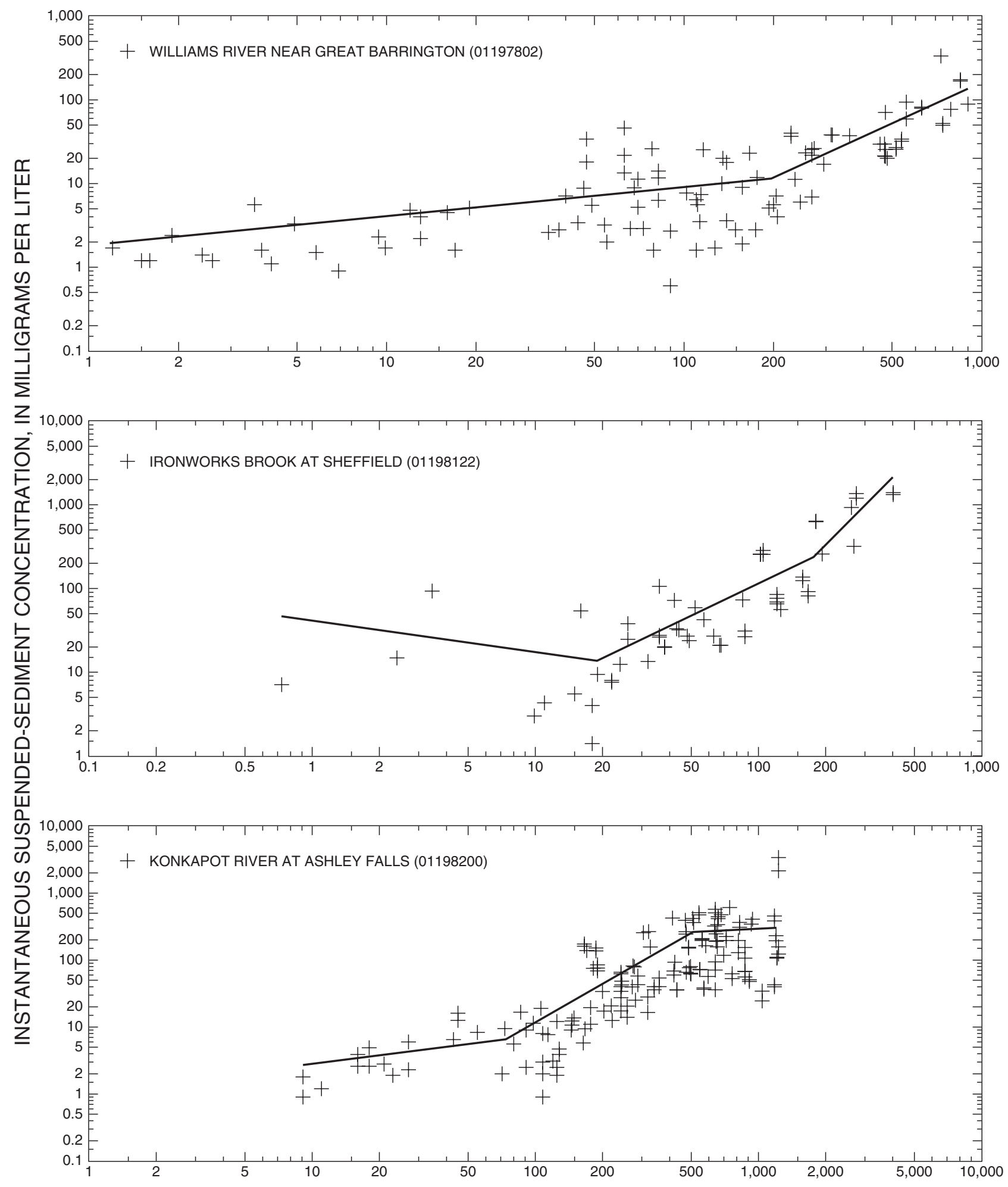

INSTANTANEOUS STREAMFLOW, IN CUBIC FEET PER SECOND

Figure 9. Relation of instantaneous suspended-sediment concentration to concurrent streamflow and associated sediment-transport curves at six sediment stations in the Housatonic River Basin, western Massachusetts, March 1994 through April 1996-Continued. 
Daily mean suspended-sediment concentrations ranged from 0 to $91 \mathrm{mg} / \mathrm{L}$ (median of $5 \mathrm{mg} / \mathrm{L}$ ) at Housatonic River near Great Barrington (station 01197500), from 0 to $220 \mathrm{mg} / \mathrm{L}$ (median of $2 \mathrm{mg} / \mathrm{L}$ ) at Green River (station 01198000), and from 1 to $131 \mathrm{mg} / \mathrm{L}$ (median of $8 \mathrm{mg} / \mathrm{L}$ ) at Housatonic River near Ashley Falls (station 01198125) (appendix 3, at back of report).

\section{Discharge}

The computed daily total suspended-sediment discharge for the three continuous-record sediment stations for samples collected from April 1994 through March 1996 are listed in appendix 3. Daily total suspended-sediment discharge ranged from 0.24 to 941 tons/d (median of 3.4 tons/d) at Housatonic River near Great Barrington (station 01197500), from 0.01 to 1,180 tons/d (median of 0.31 tons/d) at Green River (station 01198000), and 0.41 to 1,690 tons/d (median of 10 tons/d) at Housatonic River near Ashley Falls (station 01198125).

Sediment-transport equations used to compute suspended-sediment discharge at three continuousrecord and three partial-record sediment stations from April 1994 through March 1996 are shown in table 5 [no equations available for Schenob Brook (station 01198080) for previously discussed reasons]. The calculation of suspended-sediment discharge, using the flow-duration rating-curve method, at Williams River (station 01197802), Ironworks Brook (station 01198122), and Konkapot River (station 01198200) from April 1994 through March 1996 is shown in table 6. Specifically, suspended-sediment discharge is shown for streamflows that occur at the mid-points of specified flow-duration increments.

Sediment-transport curves on concurrent instantaneous suspended-sediment discharge and streamflow data at three partial-record and three continuous-record sediment stations indicate that for a given instantaneous streamflow the resulting instantaneous suspended-sediment discharge could be substantially greater or lower than the predicted value of the transport curve (fig. 10). Because of this variability in estimated instantaneous suspendedsediment discharge, the sediment-transport curves were used with the flow-duration curves to estimate total suspended-sediment discharge only at the partial- record sediment stations Williams River (01197802), Ironworks Brook (01198122), and Konkapot River (01198200) and not at stations where daily suspendedsediment discharge were calculated. Variability in the reliability of the estimates of suspended-sediment discharge also is present because continuous streamflow records (every 15 minutes) were not collected, and daily mean streamflow was based on once-a-day gage-height readings.

Segments for most of the sediment-transport curves do not appear to be the best fit of the data (fig. 10). These segments of the sediment-transport curves fit data on the high side (for example, more data points are below the curve than above it), because of the bias-correction factors in the sediment-transport equations (table 5). When the results of the sedimenttransport curve (simple linear-regression line) are multiplied by the bias-correction factor, the curve is moved upward from its position; this minimizes (equalizes) the scatter of the data above and below the line, so the residuals from the regression equation average zero. This same effect of bias-correction factors with sediment-transport equations has been shown to cause the sediment-transport curves to fit data on the high side in other sediment-transport studies (Crawford and Mansue, 1996, p. 21-23; Graf and others, 1996, p. 58).

\section{Load}

Total suspended-sediment loads (sum of suspended-sediment discharge for a defined period of time) (mass) for the Housatonic River near Great Barrington (station 01197500), Green River (station 01198000), and Housatonic River near Ashley Falls (station 01198125) from April 1994 through March 1996 are presented in table 7. The drainage area of Housatonic River near Great Barrington comprises 61 percent and Green River comprises 11 percent of the total drainage area at the Housatonic River near Ashley Falls. Streamflows at the Housatonic River near Great Barrington accounted for 59 percent and Green River accounted 11 percent of the total streamflow at the Housatonic River near Ashley Falls during April 1994 through March 1996 (table 7). These percentages are similar to the percentages of the total drainage area at the Housatonic River near Ashley Falls for the same two upstream stations. 
Table 5. Sediment-transport curve equations for continuous- and partial-record sediment stations in the Housatonic River Basin, western Massachusetts, April 1979 through September 1980 and April 1994 through March 1996

[Number of data points used in equation: The total data points used in equations for each station are greater than the total number of days for the period (daily equations) or the total number of samples taken (instantaneous equations), because data points slightly outside the range of streamflows shown in column 3 below were used. This was done to ensure that the successive sediment-transport equations for each station would be contiguous with each other. Sediment-transport curves are in the form of: $Q_{s}=\left(\right.$ bias correction factor) x exp ( $y$-intercept + slope (ln $\left.Q_{w}\right)$ ), where exp is the base of the natural logarithm (approximately exp $=2.718$ ); $Q_{s}$ is suspended-sediment discharge, in tons per day; and $\ln Q_{w}$ is the natural logarithm of streamflow, in cubic feet per second. USGS station No.: Locations shown in figure 5 and described in table 2. No., number; USGS, U.S. Geological Survey; $\mathrm{ft}^{3} / \mathrm{s}$, cubic foot per second; --, no data]

\begin{tabular}{|c|c|c|c|c|c|c|c|c|c|c|c|}
\hline \multirow[b]{2}{*}{$\begin{array}{c}\text { USGS } \\
\text { station } \\
\text { No. }\end{array}$} & \multirow[b]{2}{*}{ Station name } & \multirow{2}{*}{$\begin{array}{l}\text { Range of } \\
\text { streamflow that } \\
\text { equation is } \\
\text { applicable for } \\
\left(\mathrm{ft}^{3} / \mathrm{s}\right)\end{array}$} & \multirow[b]{2}{*}{$\begin{array}{l}\text { Bias } \\
\text { correction } \\
\text { factor }\end{array}$} & \multirow[b]{2}{*}{ Y-intercept } & \multirow[b]{2}{*}{ Slope } & \multirow{2}{*}{$\begin{array}{l}\text { Number } \\
\text { of data } \\
\text { points } \\
\text { used in } \\
\text { equation }\end{array}$} & \multirow[b]{2}{*}{ R-square } & \multicolumn{2}{|c|}{ Standard error } & \multicolumn{2}{|c|}{ p-value } \\
\hline & & & & & & & & $\begin{array}{c}\text { Y- } \\
\text { inter- } \\
\text { cept }\end{array}$ & Slope & $\begin{array}{c}\text { Y- } \\
\text { inter- } \\
\text { cept }\end{array}$ & Slope \\
\hline \multicolumn{12}{|c|}{ Using Daily Suspended-Sediment and Streamflow Data From April 1979 Through September 1980} \\
\hline \multirow[t]{3}{*}{01197500} & Housatonic River near Great Barrington & 81 to 236 & 1.0922 & -4.7905 & 1.1652 & 192 & 0.19 & 0.1744 & 0.8664 & 0.0000 & 0.0000 \\
\hline & & 236 to 482 & 1.1994 & -1.0954 & .4718 & 274 & .07 & .1016 & .5851 & .0000 & .0000 \\
\hline & & 482 to 4,060 & 1.3614 & -11.0976 & 2.0704 & 175 & .60 & .1289 & .8802 & .0000 & .0000 \\
\hline \multicolumn{12}{|c|}{ Using Instantaneous Suspended-Sediment and Streamflow Data From April 1994 Through March 1996} \\
\hline \multirow[t]{2}{*}{01197500} & Housatonic River near Great Barrington & 60 to 654 & 1.2975 & -4.5612 & 1.0181 & 163 & 0.45 & 0.0894 & 0.4953 & 0.0000 & 0.0000 \\
\hline & & 654 to 4,160 & 1.2042 & -12.3202 & 2.2263 & 129 & .83 & .0901 & .6616 & .0000 & .0000 \\
\hline \multirow[t]{2}{*}{01197802} & Williams River near Great Barrington & 1.2 to 197 & 1.4531 & -5.6797 & 1.3506 & 65 & .84 & .0749 & .2910 & .0000 & .0000 \\
\hline & & 197 to 900 & 1.2282 & -12.2296 & 2.6224 & 42 & .82 & .1962 & 1.1719 & .0000 & .0000 \\
\hline \multirow[t]{3}{*}{01198000} & Green River near Great Barrington & 2.8 to 75 & 1.5754 & -6.2015 & 1.3351 & 126 & .63 & .0927 & .2980 & .0000 & .0000 \\
\hline & & 75 to 1,220 & 1.6013 & -10.5451 & 2.3373 & 161 & .78 & .0980 & .5348 & .0000 & .0000 \\
\hline & & 1,220 to 6,440 & 1.2234 & -2.1578 & 1.1949 & 52 & .49 & .1718 & 1.2473 & .0000 & .0898 \\
\hline 01198080 & Schenob Brook at Sheffield & -- & -- & -- & -- & -- & -- & -- & -- & -- & -- \\
\hline \multirow[t]{3}{*}{01198122} & Ironworks Brook at Sheffield & 0.73 to 19 & 2.3741 & -3.0520 & .6281 & 9 & .23 & .4387 & .9825 & .1953 & .0172 \\
\hline & & 19 to 178 & 1.3884 & -7.3862 & 2.2799 & 38 & .79 & .1969 & .7734 & .0000 & .0000 \\
\hline & & 178 to 402 & 1.1757 & -14.5018 & 3.6856 & 19 & .87 & .3445 & 1.8180 & .0000 & .0000 \\
\hline \multirow[t]{3}{*}{01198125} & Housatonic River near Ashley Falls & 67 to 435 & 1.3210 & -5.6247 & 1.2267 & 116 & .44 & .1302 & .7301 & .0000 & .0000 \\
\hline & & 435 to 2,109 & 1.2808 & -11.9852 & 2.2788 & 152 & .69 & .1254 & .8950 & .0000 & .0000 \\
\hline & & 2,109 to 7,030 & 1.0916 & -5.7641 & 1.4869 & 103 & .62 & .1166 & .9496 & .0000 & .0000 \\
\hline \multirow[t]{3}{*}{01198200} & Konkapot River at Ashley Falls & 9.1 to 74 & 1.2910 & -6.0722 & 1.4145 & 37 & .73 & .1448 & .5981 & .0000 & .0000 \\
\hline & & 74 to 510 & 1.6284 & -12.8049 & 2.9242 & 71 & .65 & .2575 & 1.4447 & .0000 & .0000 \\
\hline & & 510 to 1,230 & 1.7471 & -1.7671 & 1.1422 & 65 & .10 & .4394 & 2.9160 & .0116 & .5467 \\
\hline
\end{tabular}


Table 5. Sediment-transport curve equations for continuous- and partial-record sediment stations in the Housatonic River Basin, western Massachusetts, April 1979 through September 1980 and April 1994 through March 1996-Continued

\begin{tabular}{|c|c|c|c|c|c|c|c|c|c|c|c|}
\hline \multirow[b]{2}{*}{$\begin{array}{c}\text { USGS } \\
\text { station } \\
\text { No. }\end{array}$} & \multirow[b]{2}{*}{ Station name } & \multirow{2}{*}{$\begin{array}{l}\text { Range of } \\
\text { streamflow that } \\
\text { equation is } \\
\text { applicable for } \\
\left(\mathrm{ft}^{3} / \mathbf{s}\right)\end{array}$} & \multirow[b]{2}{*}{$\begin{array}{c}\text { Bias } \\
\text { correction } \\
\text { factor }\end{array}$} & \multirow[b]{2}{*}{ Y-intercept } & \multirow[b]{2}{*}{ Slope } & \multirow{2}{*}{$\begin{array}{l}\text { Number } \\
\text { of data } \\
\text { points } \\
\text { used in } \\
\text { equation }\end{array}$} & \multirow[b]{2}{*}{ R-square } & \multicolumn{2}{|c|}{ Standard error } & \multicolumn{2}{|c|}{ p-value } \\
\hline & & & & & & & & $\begin{array}{c}\text { Y- } \\
\text { inter- } \\
\text { cept }\end{array}$ & Slope & $\begin{array}{c}\text { Y- } \\
\text { inter- } \\
\text { cept }\end{array}$ & Slope \\
\hline \multicolumn{12}{|c|}{ Using Daily Suspended-Sediment and Streamflow Data From April 1994 Through March 1996} \\
\hline \multirow[t]{2}{*}{01197500} & Housatonic River near Great Barrington & 52 to 697 & 1.2201 & -4.6402 & 1.0227 & 641 & 0.55 & 0.0363 & 0.2052 & 0.0000 & 0.0000 \\
\hline & & 697 to 4,090 & 1.1875 & -11.7427 & 2.1118 & 120 & .73 & .1175 & .8586 & .0000 & .0000 \\
\hline \multirow{2}{*}{01198000} & Green River near Great Barrington & 2.6 to 109 & 1.3853 & -5.9461 & 1.2468 & 636 & .79 & .0258 & .0944 & .0000 & .0000 \\
\hline & & 109 to 2,700 & 1.5477 & -12.1813 & 2.5521 & 129 & .76 & .1262 & .7110 & .0000 & .0000 \\
\hline \multirow[t]{3}{*}{01198125} & Housatonic River near Ashley Falls & 65 to 460 & 1.1861 & -4.8548 & 1.0885 & 349 & .51 & .0567 & .3119 & .0000 & .0000 \\
\hline & & 460 to 1,520 & 1.1458 & -11.7333 & 2.2162 & 328 & .72 & .0766 & .5173 & .0000 & .0000 \\
\hline & & 1,520 to 6,860 & 1.0918 & -9.5841 & 1.9294 & 138 & .81 & .0797 & .6175 & .0000 & .0000 \\
\hline
\end{tabular}


Table 6. Computation of suspended-sediment discharge, load, and yield at three partial-record sediment stations in the Housatonic River Basin, western Massachusetts, April 1994 through March 1996

[Sediment-transport curve equation for the three partial-record sediment stations is in table 5 . $\mathrm{ft}^{3} / \mathrm{s}$, cubic foot per second; $\left(\left(\mathrm{ft}^{3} / \mathrm{s}\right) / \mathrm{mi}^{2}\right) / \mathrm{yr}$, cubic foot per second per square mile per year; ton/d, ton per day; (ton/yr)/mi ${ }^{2}$, ton per year per square mile]

\begin{tabular}{|c|c|c|c|c|c|c|}
\hline $\begin{array}{l}\text { Flow-duration } \\
\text { percentile } \\
\text { ranges }\end{array}$ & $\begin{array}{l}\text { Flow-duration } \\
\text { increments } \\
\quad(\times 100)\end{array}$ & $\begin{array}{l}\text { Mid-points of } \\
\text { flow-duration } \\
\text { increment }\end{array}$ & $\begin{array}{c}\text { Streamflow at } \\
\text { flow-duration } \\
\text { increment } \\
\left(\mathrm{ft}^{3} / \mathrm{s}\right)\end{array}$ & $\begin{array}{l}\text { Suspended-sediment } \\
\text { discharge based on } \\
\text { sediment transport } \\
\text { curve equations } \\
\text { (ton/d) }\end{array}$ & $\begin{array}{l}\text { Streamflow } \\
\text { multiplied by } \\
\text { flow-duration } \\
\text { increment } \\
\left(\mathrm{ft}^{3} / \mathrm{s}\right)\end{array}$ & $\begin{array}{l}\text { Suspended-sediment } \\
\text { discharge multiplied } \\
\text { by flow-duration } \\
\text { increment } \\
\text { (ton/d) }\end{array}$ \\
\hline \multicolumn{7}{|c|}{ Williams River near Great Barrington (01197802) } \\
\hline $0.0-0.4$ & 0.4 & 0.2 & 699 & 172.73 & 2.80 & 0.691 \\
\hline $0.4-0.6$ & .2 & .5 & 586 & 108.78 & 1.17 & .218 \\
\hline $0.6-1$ & .4 & .8 & 541 & 88.22 & 2.16 & .353 \\
\hline $1-1.4$ & .4 & 1.2 & 525 & 81.54 & 2.10 & .326 \\
\hline $1.4-1.8$ & .4 & 1.6 & 510 & 75.57 & 2.04 & .302 \\
\hline $1.8-2.2$ & .4 & 2.0 & 464 & 58.98 & 1.86 & .236 \\
\hline $2.2-2.8$ & .6 & 2.5 & 450 & 54.43 & 2.70 & .327 \\
\hline $2.8-3.4$ & .6 & 3.1 & 382 & 35.42 & 2.29 & .213 \\
\hline $3.4-4$ & 6 & 3.7 & 328 & 23.75 & 1.97 & .142 \\
\hline $4-5$ & 1 & 4.5 & 261 & 13.04 & 2.61 & .130 \\
\hline $5-6$ & 1 & 5.5 & 230 & 9.36 & 2.30 & .094 \\
\hline $6-7$ & 1 & 6.5 & 200 & 6.49 & 2.00 & .065 \\
\hline $7-8$ & 1 & 7.5 & 185 & 5.72 & 1.85 & .057 \\
\hline $8-9$ & 1 & 8.5 & 175 & 5.31 & 1.75 & .053 \\
\hline $9-11$ & 2 & 10 & 155 & 4.51 & 3.10 & .090 \\
\hline $11-13$ & 2 & 12 & 135 & 3.74 & 2.70 & .075 \\
\hline $13-15$ & 2 & 14 & 125 & 3.37 & 2.50 & .067 \\
\hline $15-17$ & 2 & 16 & 113 & 2.94 & 2.26 & .059 \\
\hline $17-19$ & 2 & 18 & 105 & 2.66 & 2.10 & .053 \\
\hline $19-21$ & 2 & 20 & 100 & 2.49 & 2.00 & .050 \\
\hline $21-25$ & 4 & 23 & 91 & 2.20 & 3.64 & .088 \\
\hline $25-35$ & 10 & 30 & 76 & 1.72 & 7.60 & .172 \\
\hline $35-45$ & 10 & 40 & 59 & 1.22 & 5.90 & .122 \\
\hline $45-55$ & 10 & 50 & 43 & .80 & 4.30 & .080 \\
\hline $55-65$ & 10 & 60 & 32 & .54 & 3.20 & .054 \\
\hline $65-75$ & 10 & 70 & 22 & .32 & 2.20 & .032 \\
\hline $75-85$ & 10 & 80 & 14 & .18 & 1.40 & .018 \\
\hline $85-95$ & 10 & 90 & 7.6 & .08 & .76 & .008 \\
\hline $95-97$ & 2 & 96 & 3.7 & .03 & .07 & .001 \\
\hline 97-99 & 2 & 98 & 2.0 & .01 & .04 & .000 \\
\hline $99-99.6$ & 1.6 & 99.3 & 1.5 & .01 & .02 & .000 \\
\hline $99.6-100$ & .04 & 99.8 & 1.3 & .01 & .01 & .000 \\
\hline \multicolumn{5}{|c|}{ Sum } & 73.40 & 4.175 \\
\hline \multicolumn{7}{|c|}{ Total streamflow $\left(\mathrm{ft}^{3} / \mathrm{s}\right)$ and suspended-sediment load (tons) } \\
\hline \multicolumn{5}{|c|}{ 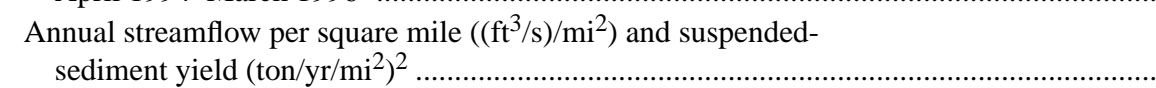 } & 621 & 35.3 \\
\hline
\end{tabular}


Table 6. Computation of suspended-sediment discharge, load, and yield at three partial-record sediment stations in the Housatonic River Basin, western Massachusetts, April 1994 through March 1996-Continued

\begin{tabular}{|c|c|c|c|c|c|c|}
\hline $\begin{array}{l}\text { Flow-duration } \\
\text { percentile } \\
\text { ranges }\end{array}$ & $\begin{array}{l}\text { Flow-duration } \\
\text { increments } \\
(\times 100)\end{array}$ & $\begin{array}{l}\text { Mid-points of } \\
\text { flow-duration } \\
\text { increment }\end{array}$ & $\begin{array}{c}\text { Streamflow at } \\
\text { flow-duration } \\
\text { increment } \\
\left(\mathrm{ft}^{3} / \mathrm{s}\right)\end{array}$ & $\begin{array}{l}\text { Suspended-sediment } \\
\text { discharge based on } \\
\text { sediment transport } \\
\text { curve equations } \\
\text { (ton/d) }\end{array}$ & $\begin{array}{l}\text { Streamflow } \\
\text { multiplied by } \\
\text { flow-duration } \\
\text { increment } \\
\left(\mathrm{ft}^{3} / \mathrm{s}\right)\end{array}$ & $\begin{array}{l}\text { Suspended-sediment } \\
\text { discharge multiplied } \\
\text { by flow-duration } \\
\text { increment } \\
\text { (ton/d) }\end{array}$ \\
\hline \multicolumn{7}{|c|}{ Ironworks Brook at Sheffield (01198122) } \\
\hline $0.0-0.4$ & 0.4 & 0.2 & 171 & 106.11 & 0.68 & 0.424 \\
\hline $0.4-0.6$ & .2 & .5 & 159 & 89.89 & .32 & .180 \\
\hline $0.6-1$ & .4 & .8 & 140 & 67.25 & .56 & .269 \\
\hline $1-1.4$ & .4 & 1.2 & 109 & 38.01 & .44 & .152 \\
\hline $1.4-1.8$ & .4 & 1.6 & 100 & 31.23 & .40 & .125 \\
\hline $1.8-2.2$ & .4 & 2.0 & 85 & 21.56 & .34 & .086 \\
\hline $2.2-2.8$ & .6 & 2.5 & 80 & 18.78 & .48 & .113 \\
\hline $2.8-3.4$ & .6 & 3.1 & 73 & 15.24 & .44 & .091 \\
\hline $3.4-4$ & .6 & 3.7 & 70 & 13.85 & .42 & .083 \\
\hline $4-5$ & 1 & 4.5 & 67 & 12.53 & .67 & .125 \\
\hline $5-6$ & 1 & 5.5 & 58 & 9.02 & .58 & .090 \\
\hline $6-7$ & 1 & 6.5 & 48 & 5.86 & .48 & .059 \\
\hline $7-8$ & 1 & 7.5 & 46 & 5.32 & .46 & .053 \\
\hline $8-9$ & 1 & 8.5 & 41 & 4.09 & .41 & .041 \\
\hline $9-11$ & 2 & 10 & 38 & 3.44 & .76 & .069 \\
\hline $11-13$ & 2 & 12 & 32 & 2.32 & .64 & .046 \\
\hline $13-15$ & 2 & 14 & 29 & 1.86 & .58 & .037 \\
\hline $15-17$ & 2 & 16 & 26 & 1.45 & .52 & .029 \\
\hline $17-19$ & 2 & 18 & 24 & 1.21 & .48 & .024 \\
\hline $19-21$ & 2 & 20 & 22 & .99 & .44 & .020 \\
\hline $21-25$ & 4 & 23 & 20 & .80 & .80 & .032 \\
\hline $25-35$ & 10 & 30 & 16 & .64 & 1.60 & .064 \\
\hline $35-45$ & 10 & 40 & 12 & .53 & 1.20 & .053 \\
\hline $45-55$ & 10 & 50 & 9.2 & .45 & .92 & .045 \\
\hline $55-65$ & 10 & 60 & 6.2 & .35 & .62 & .035 \\
\hline $65-75$ & 10 & 70 & 4.4 & .28 & .44 & .028 \\
\hline $75-85$ & 10 & 80 & 2.2 & .18 & .22 & .018 \\
\hline $85-95$ & 10 & 90 & .73 & .09 & .07 & .009 \\
\hline $95-97$ & 2 & 96 & .29 & .05 & .01 & .001 \\
\hline 97-99 & 2 & 98 & .06 & .02 & .00 & .000 \\
\hline 99-99.6 & 1.6 & 99.3 & .03 & .01 & .00 & .000 \\
\hline $99.6-100$ & .04 & 99.8 & .02 & .01 & .00 & .000 \\
\hline \multicolumn{5}{|c|}{ Sum } & 15.98 & 2.405 \\
\hline \multicolumn{7}{|c|}{ Total streamflow $\left(\mathrm{ft}^{3} / \mathrm{s}\right)$ and suspended-sediment load (tons) } \\
\hline \multicolumn{5}{|c|}{ 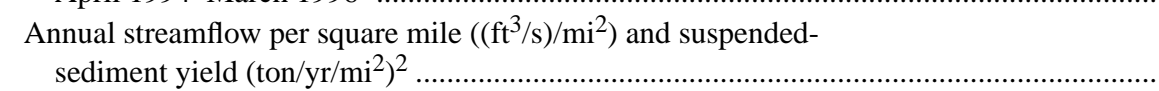 } & 521 & 78.5 \\
\hline
\end{tabular}


Table 6. Computation of suspended-sediment discharge, load, and yield at three partial-record sediment stations in the Housatonic River Basin, western Massachusetts, April 1994 through March 1996—Continued

\begin{tabular}{|c|c|c|c|c|c|c|}
\hline $\begin{array}{l}\text { Flow-duration } \\
\text { percentile } \\
\text { ranges }\end{array}$ & $\begin{array}{l}\text { Flow-duration } \\
\text { increments } \\
(\times 100)\end{array}$ & $\begin{array}{l}\text { Mid-points of } \\
\text { flow-duration } \\
\text { increment }\end{array}$ & $\begin{array}{l}\text { Streamflow at } \\
\text { flow-duration } \\
\text { increment } \\
\left(\mathrm{ft}^{3} / \mathrm{s}\right)\end{array}$ & $\begin{array}{l}\text { Suspended-sediment } \\
\text { discharge based on } \\
\text { sediment transport } \\
\text { curve equations } \\
\text { (ton/d) }\end{array}$ & $\begin{array}{l}\text { Streamflow } \\
\text { multiplied by } \\
\text { flow-duration } \\
\text { increment } \\
\left(\mathrm{ft}^{3} / \mathrm{s}\right)\end{array}$ & $\begin{array}{l}\text { Suspended-sediment } \\
\text { discharge multiplied } \\
\text { by flow-duration } \\
\text { increment } \\
\text { (ton/d) }\end{array}$ \\
\hline \multicolumn{7}{|c|}{ Konkapot River at Ashley Falls (01198200) } \\
\hline $0.0-0.4$ & 0.4 & 0.2 & 1110 & 897.93 & 4.44 & 3.592 \\
\hline $0.4-0.6$ & .2 & .5 & 815 & 630.96 & 1.63 & 1.262 \\
\hline $0.6-1$ & .4 & .8 & 728 & 554.63 & 2.91 & 2.219 \\
\hline $1-1.4$ & .4 & 1.2 & 607 & 450.64 & 2.43 & 1.803 \\
\hline $1.4-1.8$ & .4 & 1.6 & 575 & 423.61 & 2.30 & 1.694 \\
\hline $1.8-2.2$ & .4 & 2.0 & 513 & 371.85 & 2.05 & 1.487 \\
\hline $2.2-2.8$ & .6 & 2.5 & 476 & 302.36 & 2.86 & 1.814 \\
\hline $2.8-3.4$ & .6 & 3.1 & 451 & 258.23 & 2.71 & 1.549 \\
\hline $3.4-4$ & .6 & 3.7 & 410 & 195.42 & 2.46 & 1.173 \\
\hline $4-5$ & 1 & 4.5 & 381 & 157.69 & 3.81 & 1.577 \\
\hline $5-6$ & 1 & 5.5 & 333 & 106.36 & 3.33 & 1.064 \\
\hline $6-7$ & 1 & 6.5 & 295 & 74.63 & 2.95 & .746 \\
\hline $7-8$ & 1 & 7.5 & 270 & 57.60 & 2.70 & .576 \\
\hline $8-9$ & 1 & 8.5 & 244 & 42.84 & 2.44 & .428 \\
\hline $9-11$ & 2 & 10 & 226 & 34.24 & 4.52 & .685 \\
\hline $11-13$ & 2 & 12 & 200 & 23.95 & 4.00 & .479 \\
\hline $13-15$ & 2 & 14 & 184 & 18.77 & 3.68 & .375 \\
\hline $15-17$ & 2 & 16 & 166 & 13.89 & 3.32 & .279 \\
\hline $17-19$ & 2 & 18 & 150 & 10.33 & 3.00 & .207 \\
\hline $19-21$ & 2 & 20 & 146 & 9.54 & 2.92 & .191 \\
\hline $21-25$ & 4 & 23 & 134 & 7.43 & 5.36 & .297 \\
\hline $25-35$ & 10 & 30 & 113 & 4.51 & 11.30 & .451 \\
\hline $35-45$ & 10 & 40 & 89 & 2.24 & 8.90 & .224 \\
\hline $45-55$ & 10 & 50 & 74 & 1.31 & 7.40 & .131 \\
\hline $55-65$ & 10 & 60 & 60 & .97 & 6.00 & .097 \\
\hline $65-75$ & 10 & 70 & 43 & .61 & 4.30 & .061 \\
\hline $75-85$ & 10 & 80 & 30 & .37 & 3.00 & .037 \\
\hline $85-95$ & 10 & 90 & 21 & .22 & 2.10 & .022 \\
\hline $95-97$ & 2 & 96 & 13 & .11 & .26 & .002 \\
\hline 97-99 & 2 & 98 & 11 & .09 & .22 & .002 \\
\hline 99-99.6 & 1.6 & 99.3 & 9.1 & .07 & .15 & .001 \\
\hline $99.6-100$ & .04 & 99.8 & 8.3 & .06 & .03 & .000 \\
\hline \multicolumn{5}{|c|}{ Sum } & 109.47 & 24.524 \\
\hline \multicolumn{7}{|c|}{ Total streamflow $\left(\mathrm{ft}^{3} / \mathrm{s}\right)$ and suspended-sediment load (tons) } \\
\hline \multicolumn{4}{|c|}{ 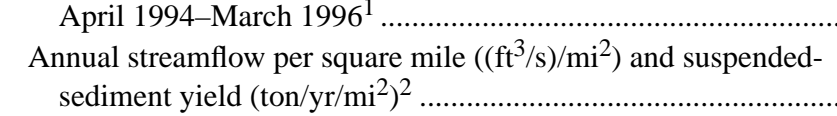 } & & 655 & 147 \\
\hline
\end{tabular}

${ }^{1}$ Total April 1994-March 1996 is the sum of the column times 731 days (number of days during the 2-year study period).

${ }^{2}$ Annual per square mile is the total April 1994-March 1996 divided by each station's respective drainage basin area (Williams River 43.2 mi ${ }^{2}$, Ironworks Brook $11.2 \mathrm{mi}^{2}$, and Konkapot River $61.1 \mathrm{mi}^{2}$ ) divided by 2 years. 

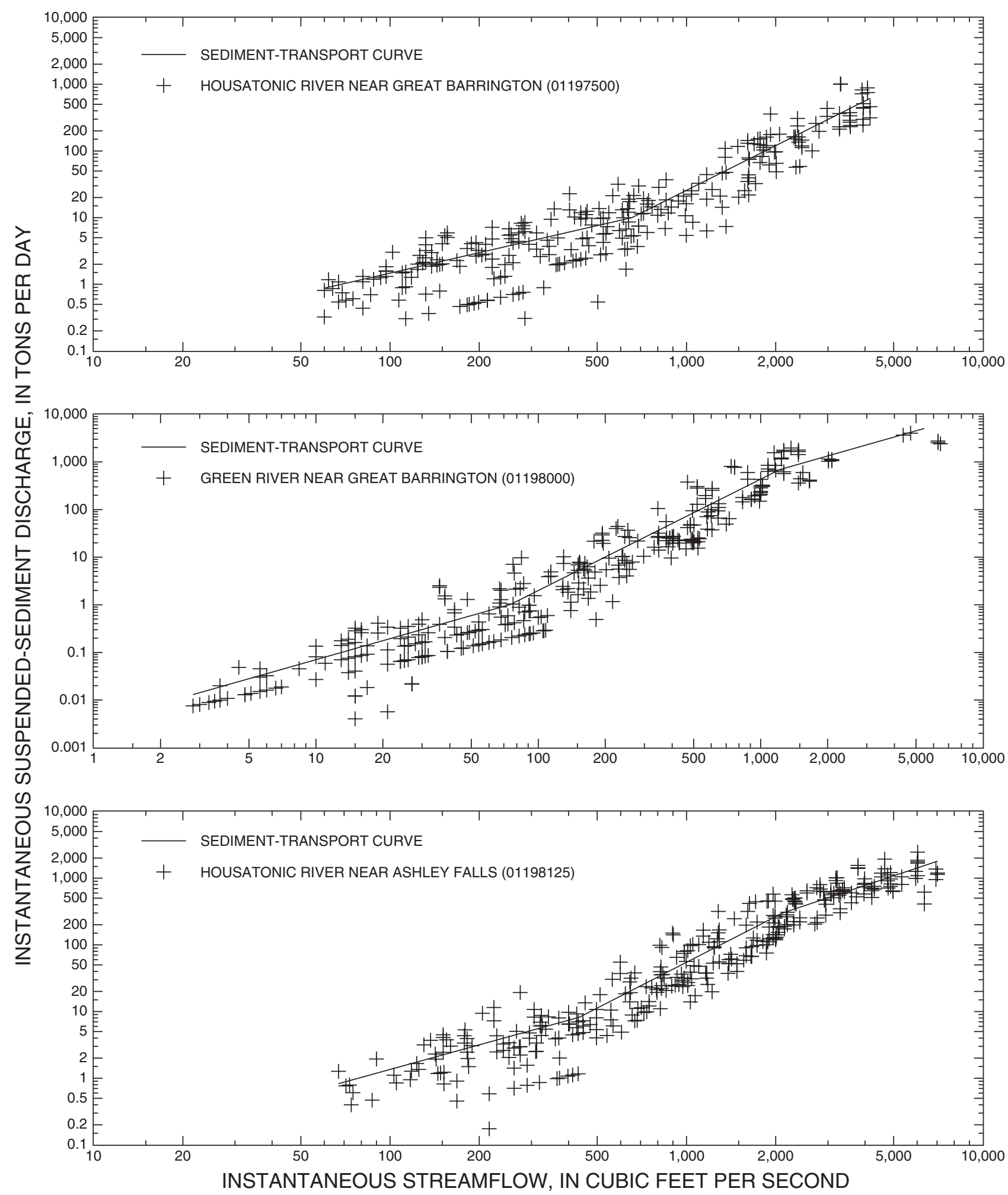

Figure 10. Relation of instantaneous suspended-sediment discharge to concurrent streamflow and associated sedimenttransport curves at six sediment stations in the Housatonic River Basin, western Massachusetts, March 1994 through April 1996. 


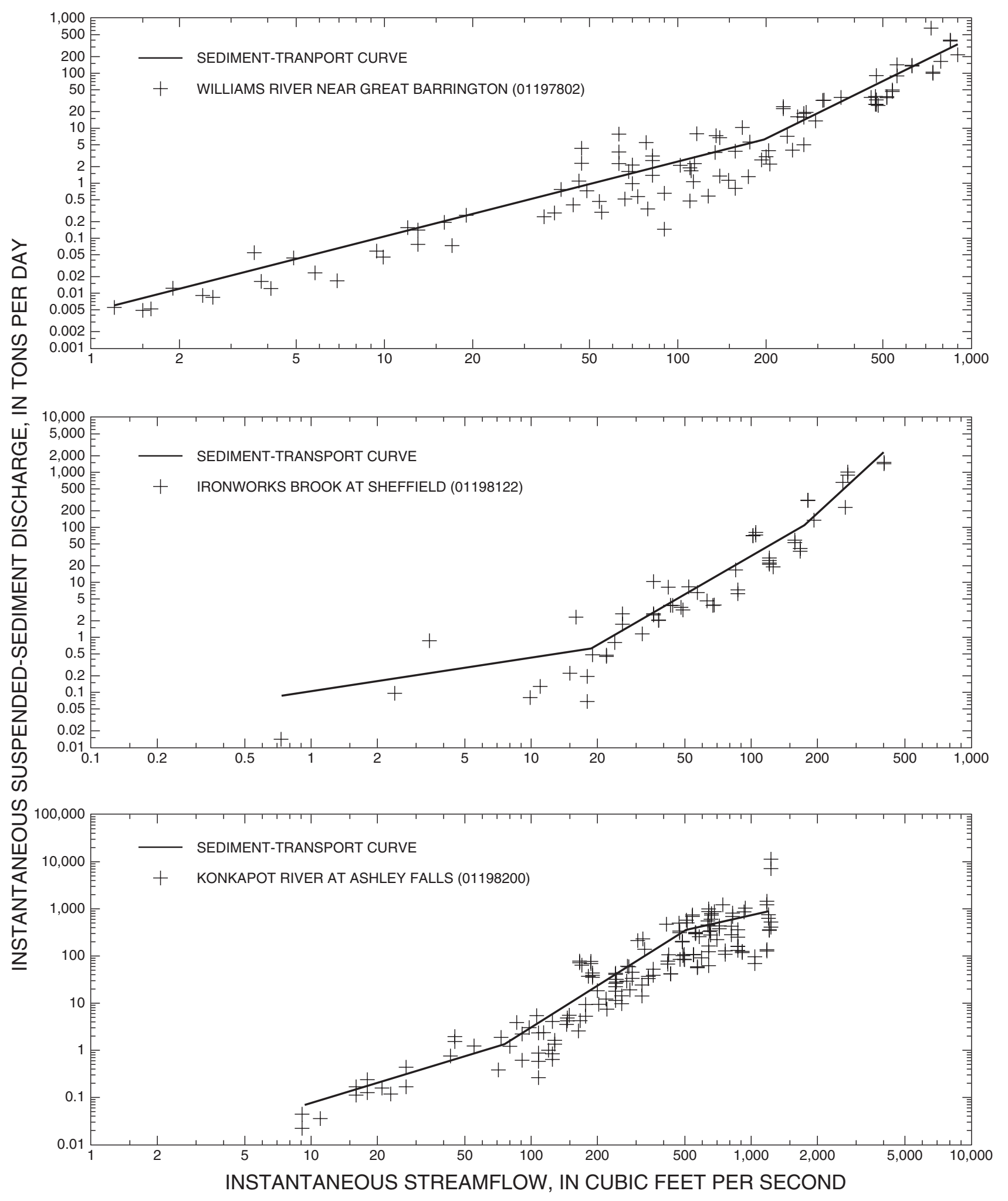

Figure 10. Relation of instantaneous suspended-sediment discharge to concurrent streamflow and associated sedimenttransport curves at six sediment stations in the Housatonic River Basin, western Massachusetts, March 1994 through April 1996-Continued. 
Table 7. Streamflow and suspended-sediment load at continuous- and partial-record sediment stations in the Housatonic River Basin, western Massachusetts, April 1994 through March 1996

[Normal precipitation for April through September is $24.7 \mathrm{in}$., for October through March is $20.1 \mathrm{in}$., and for October through September (water year) is 44.8 in. based on 1961-90 climatological data at Great Barrington Airport (station 193213) (U.S. Department of Commerce, National Oceanic Atmospheric Administration, 1993). USGS station No.: Locations shown in figure 5 and described in table 2. No., number; USGS, U.S. Geological Survey; $\mathrm{ft}^{3} / \mathrm{s}$, cubic feet per second; in., inch; $\mathrm{mi}^{2}$, square miles; --, not applicable]

\begin{tabular}{|c|c|c|c|c|c|c|c|}
\hline $\begin{array}{l}\text { USGS } \\
\text { station } \\
\text { No. }\end{array}$ & Station name & $\begin{array}{c}\text { Drainage } \\
\text { area } \\
\left(\mathrm{mi}^{2}\right)\end{array}$ & $\begin{array}{c}\text { Percentage of } \\
\text { total drainage } \\
\text { area at } \\
\text { Housatonic } \\
\text { River near } \\
\text { Ashley Falls }\end{array}$ & $\begin{array}{c}\text { Sum of } \\
\text { daily mean } \\
\text { streamflow } \\
\left(\mathrm{ft}^{3} / \mathrm{s}\right)\end{array}$ & $\begin{array}{c}\text { Percentage of } \\
\text { total daily mean } \\
\text { streamflow at } \\
\text { Housatonic } \\
\text { River near } \\
\text { Ashley Falls }\end{array}$ & $\begin{array}{l}\text { Total } \\
\text { suspended- } \\
\text { sediment } \\
\text { load } \\
\text { (ton) }\end{array}$ & $\begin{array}{l}\text { Percentage of total } \\
\text { suspended- } \\
\text { sediment } \\
\text { discharge at } \\
\text { Housatonic River } \\
\text { near Ashley Falls }\end{array}$ \\
\hline
\end{tabular}

Continuous-Record Sediment Stations

\begin{tabular}{|c|c|c|c|c|c|c|c|}
\hline \multicolumn{8}{|c|}{ April Through September 1994 (precipitation = 23.2 in.) } \\
\hline 01197500 & $\begin{array}{l}\text { Housatonic River near } \\
\text { Great Barrington }\end{array}$ & 282 & 61 & 108,751 & 62 & 3,973 & 26 \\
\hline 01198000 & $\begin{array}{l}\text { Green River near Great } \\
\text { Barrington }\end{array}$ & 51.0 & 11 & 18,244 & 10 & 1,292 & 8.6 \\
\hline 01198125 & $\begin{array}{l}\text { Housatonic River near } \\
\text { Ashley Falls }\end{array}$ & 465 & 100 & 174,989 & 100 & 15,029 & 100 \\
\hline \multicolumn{8}{|c|}{ Water Year 1995 (precipitation = 29.4 in.) } \\
\hline 01197500 & $\begin{array}{l}\text { Housatonic River near } \\
\text { Great Barrington }\end{array}$ & 282 & 61 & 135,527 & 58 & 2,192 & 18 \\
\hline 01198000 & $\begin{array}{l}\text { Green River near Great } \\
\text { Barrington }\end{array}$ & 51.0 & 11 & 23,837 & 10 & 1,219 & 10 \\
\hline 01198125 & $\begin{array}{l}\text { Housatonic River near } \\
\text { Ashley Falls }\end{array}$ & 465 & 100 & 231,842 & 100 & 12,236 & 100 \\
\hline \multicolumn{8}{|c|}{ October Through March 1996 (precipitation = 32.4 in.) } \\
\hline 01197500 & $\begin{array}{l}\text { Housatonic River near } \\
\text { Great Barrington }\end{array}$ & 282 & 61 & 147,129 & 58 & 5,466 & 20 \\
\hline 01198000 & $\begin{array}{l}\text { Green River near Great } \\
\text { Barrington }\end{array}$ & 51.0 & 11 & 29,245 & 11 & 5,418 & 20 \\
\hline 01198125 & $\begin{array}{l}\text { Housatonic River near } \\
\text { Ashley Falls }\end{array}$ & 465 & 100 & 254,514 & 100 & 27,082 & 100 \\
\hline \multicolumn{8}{|c|}{ TOTAL April 1994 Through March 1996 (precipitation = 85.0 in.) } \\
\hline 01197500 & $\begin{array}{l}\text { Housatonic River near } \\
\text { Great Barrington }\end{array}$ & 282 & 61 & 391,407 & 59 & 11,603 & 21 \\
\hline 01198000 & $\begin{array}{l}\text { Green River near Great } \\
\text { Barrington }\end{array}$ & 51.0 & 11 & 71,326 & 11 & 7,929 & 15 \\
\hline 01198125 & $\begin{array}{l}\text { Housatonic River near } \\
\text { Ashley Falls }\end{array}$ & 465 & 100 & 661,345 & 100 & 54,347 & 100 \\
\hline \multicolumn{8}{|c|}{ PARTIAL-RECORD SEDIMENT STATIONS } \\
\hline \multicolumn{8}{|c|}{ TOTAL April 1994 Through March 1996 (precipitation = 85.0 in) } \\
\hline 01197802 & $\begin{array}{l}\text { Williams River near Great } \\
\text { Barrington }\end{array}$ & 43.2 & 9.3 & 53,656 & 8.1 & 3,052 & 5.6 \\
\hline 01198122 & $\begin{array}{l}\text { Ironworks Brook at } \\
\text { Sheffield }\end{array}$ & 11.2 & 2.4 & 11,679 & 1.8 & 1,758 & 3.2 \\
\hline $01198200^{1}$ & $\begin{array}{l}\text { Konkapot River at Ashley } \\
\text { Falls }\end{array}$ & 61.1 & -- & 80,025 & -- & 17,927 & -- \\
\hline
\end{tabular}

\footnotetext{
${ }^{1}$ Konkapot River at Ashley Falls drains into the Housatonic River downstream from the Housatonic River near Ashley Falls (01198125).
} 
The percentage of total suspended-sediment load at Green River to the Housatonic River near Ashley Falls (15 percent) was similar to the Green River percentage of the total drainage area at the Housatonic River near Ashley Falls (11 percent). But the percentage of total suspended-sediment load at Housatonic River near Great Barrington to the Housatonic River near Ashley Falls was about 2 to 3 times less (21 percent) than the Housatonic River near Great Barrington percentage of the total drainage area at the Housatonic River near Ashley Falls (61 percent). One possible explanation is that the Housatonic River near Great Barrington is only about $0.8 \mathrm{mi}$ downstream from Rising Pond Dam. Upstream from Rising Pond Dam are four additional major dams on the main stem of the Housatonic River (fig. 5) that would be expected to trap stream sediments.

Monthly total suspended-sediment load for the three continuous sediment stations during water years 1994-96 are shown in appendix 3 as the total of sediment discharge for each month. The load for January 1996 accounted for about 54 percent of total suspended-sediment load at Green River (station 01198000) during April 1994 through March 1996, and January 19 and 20, 1996 accounted for about 50 percent of the total for January or about 27 percent of the total for the 2-year study. This was the result of rainfall-snowmelt runoff on January 19 and 20, 1996 (about the equivalent of 5 to 6 in. of rainfall), as described previously in the "Climatic and Hydrologic Conditions" section, in the Green River subbasin.
During 1 percent of the 2-year study (about 7 days), the percentage of the total suspended-sediment load discharged was 49 at Housatonic River near Great Barrington (station 01197500), 76 at Green River (station 01198000), and 35 at Housatonic River near Ashley Falls (station 01198125). During 10 percent of the 2-year study (about 73 days) about 95, 99, and 93 percent of the total suspended-sediment load was discharged at these three sediment stations, respectively.

The Housatonic River near Great Barrington (station 01197500) also was operated as a continuousrecord sediment station from April 1979 through September 1980 (U.S. Geological Survey, 1981, p. 255-257). Precipitation during the 1979-80 study was $0.4 \mathrm{in} / \mathrm{yr}$ less (or about 1 percent less) than during the April 1994 through 1996 study (table 8). Total daily mean streamflow per year during 1979-80 was about 8 percent less than during 1994-96. Flowduration curves for the two periods (fig. 8) indicate that streamflows at flow durations less than about 15 percent were greater during 1994-96 than during 1979-80, and streamflows at flow durations greater than about 80 percent were lower during 1994-96 than during 1979-80.

Suspended-sediment yield at Housatonic River near Great Barrington (station 01197500) from April 1979 through September 1980 was about 23 percent greater than from April 1994 through March 1996 (table 8). Sediment-transport curves developed using daily suspended-sediment discharge and daily mean streamflow for the two periods also indicate that

Table 8. Precipitation, streamflow, suspended-sediment load, and suspended-sediment yield at the Housatonic River near Great Barrington, Massachusetts, in the Housatonic River Basin April 1979 through 1980 and April 1994 through March 1996

[Normal precipitation for April through September is 24.7 in., for October through March is 20.1 in., for October through September (water year) is 44.8 in. based on 1961-90 climatological data at Great Barrington Airport (station 193213) (U.S. Department of Commerce, National Oceanic Atmospheric Administration, 1993). USGS station No.: Locations shown in figure 5 and described in table 2. No., number; USGS, U.S. Geological Survey; $\mathrm{ft}^{3} / \mathrm{s}$, cubic foot per second; $\left(\left(\mathrm{ft}^{3} / \mathrm{s}\right) / \mathrm{yr}\right) / \mathrm{mi}^{2}$, cubic foot per second per year per square mile; in., inch; in/yr, inches per year; (ton/yr)/mi ${ }^{2}$, ton per year per square mile]

\begin{tabular}{|c|c|c|c|c|c|c|c|}
\hline $\begin{array}{c}\text { USGS } \\
\text { station } \\
\text { No. }\end{array}$ & Station name & $\begin{array}{l}\text { Total } \\
\text { precipi- } \\
\text { tation } \\
\text { (in.) }\end{array}$ & $\begin{array}{c}\text { Annual } \\
\text { precipi- } \\
\text { tation } \\
\text { (in/yr) }\end{array}$ & $\begin{array}{c}\text { Total of } \\
\text { daily mean } \\
\text { streamflow } \\
\left(\mathrm{ft}^{3} / \mathrm{s}\right)\end{array}$ & $\begin{array}{c}\text { Annual } \\
\text { total of } \\
\text { daily mean } \\
\text { streamflow } \\
\left(\left(\left(\mathrm{ft}^{3} / \mathrm{s}\right) / \mathrm{yr}\right) / \mathrm{mi}^{2}\right)\end{array}$ & $\begin{array}{c}\text { Total } \\
\text { suspended- } \\
\text { sediment } \\
\text { load } \\
\text { (ton) }\end{array}$ & $\begin{array}{c}\text { Annual } \\
\text { suspended- } \\
\text { sediment } \\
\text { yield } \\
\left((\text { ton } / \mathrm{yr}) / \mathrm{mi}^{2}\right)\end{array}$ \\
\hline
\end{tabular}

April 1979 Through September 1980

$\begin{array}{llllll}01197500 & \text { Housatonic River near Great Barrington } \quad 63.0 & 42.0 & 268,775 & 635 & 10,718\end{array}$

April 1994 Through March 1996

$\begin{array}{lllllll}01197500 & \text { Housatonic River near Great Barrington } \quad 85.0 \quad 42.5 & 391,407 & 694 \quad 20.6\end{array}$


sediment transport was higher in 1979-80 than in 1994-96 for all ranges of streamflow at the Housatonic River near Great Barrington (fig. 11). The greater suspended-sediment yield during 1979-80 may be due to four high runoff events, one during May 1979, two during March 1980 and one during April 1980 (U.S. Geological Survey, 1981, p. 255-257) when about 50 percent of the total suspended-sediment load for the 1.5-year study was discharged, but high runoff events during April 1994 and January 1996 streamflows produced about 50 percent of the suspended-sediment load during the 1994-96 study. Other factors, such as differences in climate, land-use practices, or sediment trapped by upstream dams also may have contributed to the differences in suspended-sediment yields between the two periods.

Total suspended-sediment load, calculated using the flow-duration, rating-curve method (table 6) for Williams River (station 01197802), Ironworks Brook (station 01198122), and Konkapot River (station 01198200) for April 1994 through March 1996 are presented in table 7 . The percentages of total streamflow at Housatonic River near Ashley Falls (station 01198125) contributed by Williams River (8.1 percent) and Ironworks Brook (1.8 percent) were slightly less than the percentages of contributing drainage area of the two stations to the Housatonic River near Ashley Falls drainage area (9.3 percent for Williams River and 2.4 percent for Ironworks Brook). The percentages of total suspended-sediment load at Housatonic River near Ashley Falls contributed by Williams River (5.6 percent) and Ironworks Brook (3.2 percent) were less and greater, respectively, than the percentage of contributing drainage area of the two stations to the Housatonic River near Ashley Falls drainage area. The Konkapot River, which flows to the Housatonic River below the sediment station at the Housatonic River near Ashley Falls, had the second highest total suspended-sediment load when compared to the other sediment stations (both continuous record and partial record) sampled during the 2-year study (table 7).

During 1 percent of the 2-year study (about 7 days) the percentage of the total suspended-sediment load discharged was 30 at Williams River (station 01197802), 36 at Ironworks Brook (station 01198122), and 29 at Konkapot River (station 01198200). During 10 percent of the study period (about 73 days) about
78,80 , and 87 percent of the total suspended-sediment load was discharged at these three sediment stations, respectively.

\section{Yield}

Median instantaneous suspended-sediment yields at Housatonic River near Great Barrington (station 01197500), Williams River (station 01197802), and Green River (station 01198000) were fairly similar, but yields at Housatonic River near Ashley Falls (station 01198125) were about twice as great as those of these three sediment stations (table 4). At Ironworks Brook (station 01198122) and Konkapot River (station 01198200), median instantaneous suspended-sediment yields were several times greater than at the other five sediment stations. The high instantaneous suspendedsediment yields at Ironworks Brook and Konkapot River are partly due to the fact that the median instantaneous streamflows per square mile during suspended-sediment sampling at these two stations were at least twice that of the other sediment stations except Schenob Brook (station 01198080).

Monthly suspended-sediment yields at the three continuous-record sediment stations from April 1994 through March 1996 are shown in figure 6. The most notable difference in monthly suspended-sediment yield was observed during January 1996, when the yield at Green River (station 01198000) was about 840 percent greater than at Housatonic River near Great Barrington (station 01197500) and 336 percent greater than at Housatonic River near Ashley Falls (station 01198125). This difference in suspended-sediment yield was the result of rainfall-snowmelt runoff on January 19 and 20, 1996 (the equivalent of about 5 to 6 in. of rainfall) in the Green River subbasin. During the other months of the 2-year study, suspendedsediment yields differed between sediment stations, but yields at the Housatonic River near Ashley Falls were always higher than yields at the Housatonic River near Great Barrington.

Suspended-sediment yields for October 1995 and January 1996 at the three continuous-record sediment stations were different, although monthly total precipitation amounts were similar [October 1995 (9.8 in.) and January (9.6 in.) at the Great Barrington Airport Climatological Station (3213)] (fig. 6). Total streamflow and suspended-sedimentdischarge for the 2 months also were different. The 


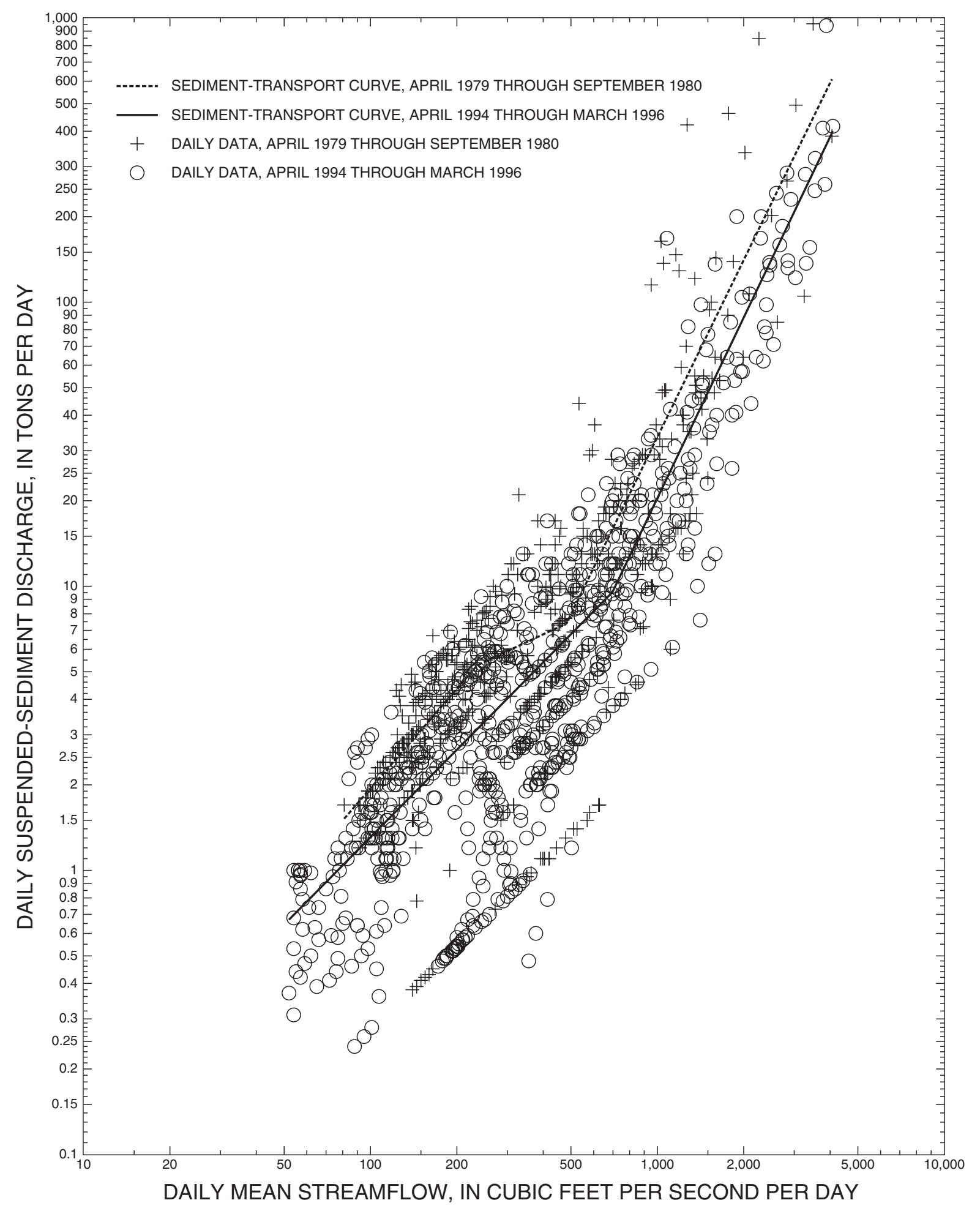

Figure 11. Relation of daily suspended-sediment discharge to daily mean streamflow and associated sedimenttransport curves for the Housatonic River near Great Barrington, Mass. (station 01197500), April 1979 through September 1980 and April 1994 through March 1996. 
sum of total daily mean streamflow per square mile was about 2.0 times greater at Housatonic River near Great Barrington (station 01197500), 4.8 times greater at Green River (station 01198000), and 2.6 times greater at Housatonic River near Ashley Falls (station 01198125) for January 1996 than for October 1995.

Suspended-sediment yield was about 3.1 times greater at Housatonic River near Great Barrington, 18.5 times greater at Green River, and 4.0 times greater at Housatonic River near Ashley Falls for January 1996 than for October 1995. Possible reasons for the different response in suspended-sediment yield between October 1995 and January 1996 are (1) rainfall-snowmelt runoff on January 19 and 20, 1996, in which 2.0 in. of rain fell and snow depth was reduced from 42 to 6 in., about the equivalent of 5 to 6 in. of rainfall-resulting in more runoff; (2) soils being frozen during January thus smaller infiltration rates for rain and snowmelt-resulting in more runoff; (3) below-normal precipitation from May through September 1995 leading to drier soil conditions and allowing for greater infiltration rates for rain during October 1995-resulting in less runoff; (4) four significant rainfalls during October 1995 (1.2 to 3.5 in.) about 6 to 9 days apart, allowing more drying of the soils during the higher temperatures of October than January-resulting in less runoff; and (5) more vegetation in October than in January leading to more soil coverage, canopy interception, and evapotranspiration of precipitation-resulting in less soil erosion and runoff.

Suspended-sediment yield for the 2-year study at the three continuous-record stations was highest at Green River (station 01198000) and lowest at the Housatonic River near Great Barrington (station 01197500) (table 9). Suspended-sediment yield at the Housatonic River near Ashley Falls (station 01198125) was about 2.8 times that determined at the Housatonic River near Great Barrington. The suspended-sediment yield of 21 (tons/yr) $/ \mathrm{mi}^{2}$ at the Housatonic River near Great Barrington from April 1994 through March 1996 compared well to a previous period of suspendedsediment yield data—25 (tons/yr) $/ \mathrm{mi}^{2}$ from April 1979 through September 1980 (table 8).

Table 9. Suspended-sediment yield, streamflow, and selected basin and land-use characteristics for continuous- and partialrecord sediment stations in the Housatonic River Basin, western Massachusetts, April 1994 through March 1996

[USGS station No.: Locations shown in figure 5 and described in table 2. Total soils with soil erodibility factor of 0.49 : Total soils with soil erodibility factor of 0.49 equals the sum of Hadley, Limerick, Linlithgo, Saco, and Winooski silt loam soils. GRID, surface modeling package in ARCINFO;

No., number; USGS, U.S. Geological Survey; $\left(\left(\mathrm{ft}{ }^{3} / \mathrm{s}\right) / \mathrm{yr}\right) / \mathrm{mi}^{2}$, cubic feet per second per year per square mile; $\mathrm{mi}^{2}$, square miles; (ton $\left./ \mathrm{yr}\right) / \mathrm{mi}^{2}$, ton per year per square mile; --, no data.]

\begin{tabular}{|c|c|c|c|c|c|c|}
\hline $\begin{array}{l}\text { USGS } \\
\text { station } \\
\text { No. }\end{array}$ & Station name & $\begin{array}{l}\text { Drainage } \\
\text { area } \\
\left(\mathrm{mi}^{2}\right)\end{array}$ & $\begin{array}{l}\text { Suspended- } \\
\text { sediment yield } \\
\left((\text { ton/yr }) / \mathrm{mi}^{2}\right)\end{array}$ & $\begin{array}{c}\text { Total of } \\
\text { daily mean } \\
\text { streamflow } \\
\left(\left(\left(\mathrm{ft}^{3} / \mathrm{s}\right) / \mathrm{yr}\right) / \mathrm{mi}^{2}\right)\end{array}$ & $\begin{array}{l}\text { Stratified-drift } \\
\text { area } \\
\text { (percent) }\end{array}$ & $\begin{array}{l}\text { Carbonate } \\
\text { rocks area } \\
\text { (percent) }\end{array}$ \\
\hline 01197500 & $\begin{array}{l}\text { Housatonic River near Great } \\
\text { Barrington, Mass. }\end{array}$ & 282 & 20.6 & 694 & 13.4 & 36.8 \\
\hline 01197802 & $\begin{array}{l}\text { Williams River near Great } \\
\text { Barrington, Mass. }\end{array}$ & 43.2 & 35.3 & 621 & 12.1 & 46.6 \\
\hline 01198000 & $\begin{array}{l}\text { Green River near Great Barrington, } \\
\text { Mass. }\end{array}$ & 51.0 & 77.7 & 699 & 10.1 & 34.5 \\
\hline 01198080 & Schenob Brook at Sheffield, Mass. & 50.0 & 181.6 & -- & 25.6 & 69.4 \\
\hline 01198122 & Ironworks Brook at Sheffield, Mass. & 11.2 & 78.4 & 521 & 3.6 & 56.8 \\
\hline $\begin{array}{l}\text { Area adjace } \\
\text { Great } \mathrm{Ba} \\
\text { Mass. }\end{array}$ & $\begin{array}{l}\text { nt to the Housatonic River between } \\
\text { rington, Mass., and Ashley Falls, }\end{array}$ & 27.6 & ${ }^{2} 395.3$ & -- & 45.3 & 55.1 \\
\hline 01198125 & $\begin{array}{l}\text { Housatonic River near Ashley Falls, } \\
\text { Mass. }\end{array}$ & 465 & 58.4 & 711 & 15.9 & 42.5 \\
\hline 01198200 & $\begin{array}{l}\text { Konkapot River at Ashley Falls, } \\
\text { Mass. }\end{array}$ & 61.1 & 146.6 & 655 & 17.4 & 43.4 \\
\hline
\end{tabular}


Table 9. Suspended-sediment yield, streamflow, and selected basin and land-use characteristics for continuous- and partialrecord sediment stations in the Housatonic River Basin, western Massachusetts, April 1994 through March 1996—Continued

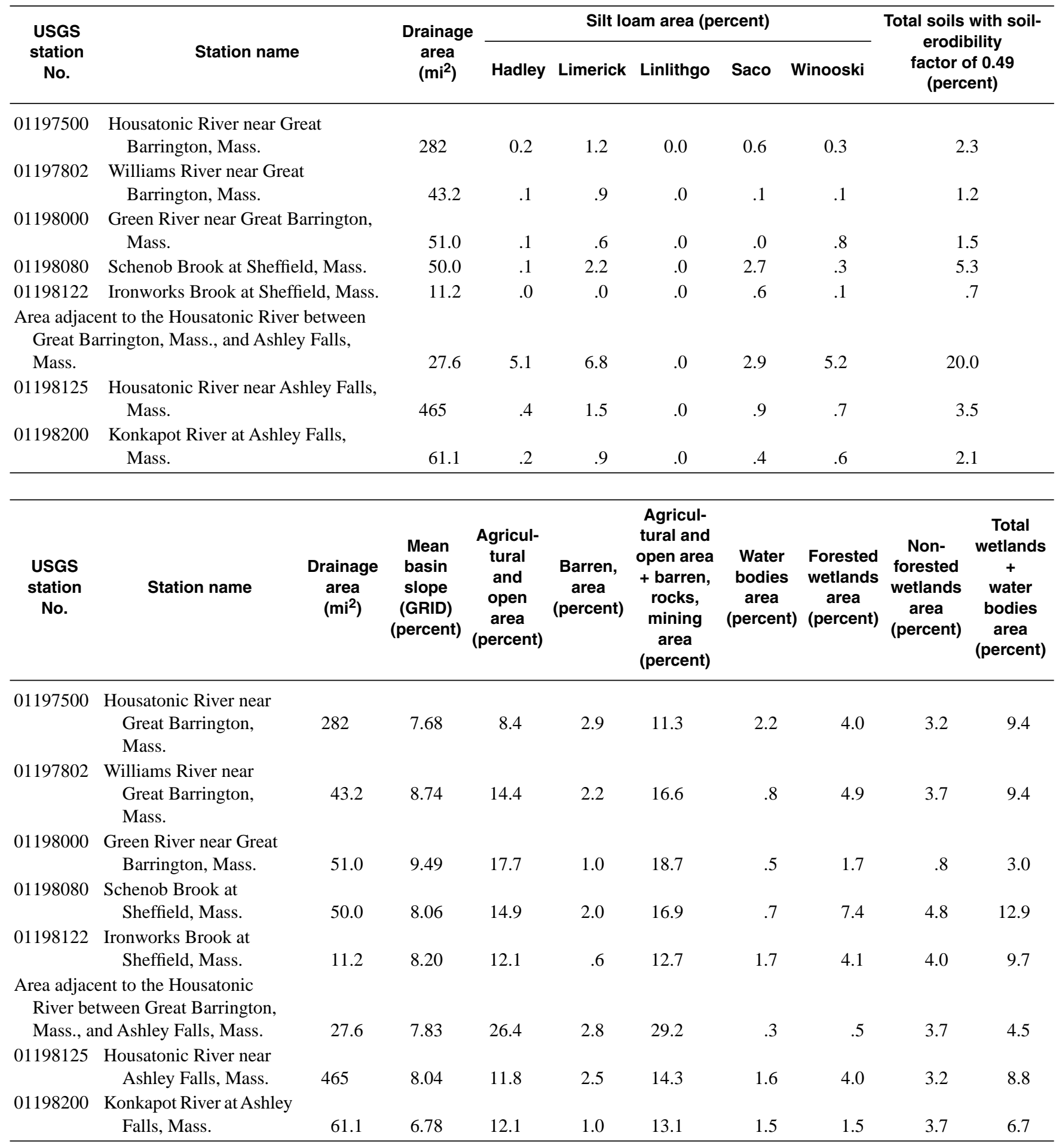

${ }^{1}$ Suspended-sediment yield was estimated using suspended-sediment yield of the Housatonic River near Great Barrington for 25.8 mi $^{2}$ of Hubbard Brook and suspended-sediment yield of the Konkapot River for $24.2 \mathrm{mi}^{2}$ of Schenob Brook.

${ }^{2}$ Suspended-sediment yield was estimated by subtracting the suspended-sediment discharge of the stations upstream of the Housatonic River near Ashley Falls from the suspended-sediment discharge at the Housatonic River near Ashley Falls (Station 01198125 - Stations 01197500, 01197802, 01198000, 01198080, and 01198122) and then dividing by $27.6 \mathrm{mi}^{2}$. 
Estimates of suspended-sediment yield for Williams River (station 01197802), Ironworks Brook (station 01198122), and Konkapot River (station 01198200) ranged widely between stations during April 1994 through March 1996 (table 9). The Williams River had the lowest estimated suspendedsediment yield, and the Konkapot River had the highest estimated suspended-sediment yield. The Williams River suspended-sediment yield was almost twice that of the Housatonic River near Great Barrington (station 01197500), and the Ironworks Brook suspendedsediment yield compared well with the Green River (station 01198000) (table 9). The Konkapot River suspended-sediment yield was about 2 to 7 times greater than that of the other sediment stations.

The sediment-transport curves of instantaneous suspended-sediment yield and concurrent streamflow per square mile (the same sediment-transport curves shown in fig. 10 but normalized by drainage area) were plotted for the three continuous-record and three partial-record sediment stations (fig. 12). The sediment-transport curves of instantaneous suspendedsediment yield at each station for streamflows ranging from 8 to $20\left(\mathrm{ft}^{3} / \mathrm{s}\right) / \mathrm{mi}^{2}$ in figure 12 generally went from lowest to highest in the same order as the yields in table 9 [Housatonic River near Great Barrington (station 01197500), Williams River (station 01197802), Housatonic River near Ashley Falls (station 01198125), Green River (station 01198000), Ironworks Brook (station 01198122), and Konkapot River (station 01198200)]. At instantaneous streamflows less than $1\left(\mathrm{ft}^{3} / \mathrm{s}\right) / \mathrm{mi}^{2}$, instantaneous suspended-sediment yields were highest at Ironworks Brook and lowest at the Housatonic River near Ashley Falls (fig. 12). The slopes of the sediment-transport curves varied widely at streamflows less than $1\left(\mathrm{ft}^{3} / \mathrm{s}\right) / \mathrm{mi}^{2}$. At instantaneous streamflows between 1 to $2\left(\mathrm{ft}^{3} / \mathrm{s}\right) / \mathrm{mi}^{2}$, instantaneous suspended-sediment yields changed as sedimenttransport curves for the six sediment stations crossed each other. At instantaneous streamflows ranging from 2 to $8\left(\mathrm{ft}^{3} / \mathrm{s}\right) / \mathrm{mi}^{2}$, instantaneous suspended-sediment yields at Ironworks Brook, Housatonic River near Ashley Falls, and Konkapot River were similar but were higher than those at Housatonic River near Great Barrington, Williams River, and Green River (fig. 12). Housatonic River near Great Barrington and Williams River had similar yields, which were lower than Green River at streamflows ranging from 2 to $8\left(\mathrm{ft}^{3} / \mathrm{s}\right) / \mathrm{mi}^{2}$. The slopes of the sediment-transport curves were similar for all six stations at streamflows ranging from 2 to $8\left(\mathrm{ft}^{3} / \mathrm{s}\right) / \mathrm{mi}^{2}$.
For Schenob Brook at Sheffield (station 01198080), which was affected by back-water conditions and only sampled seven times, suspendedsediment yield was estimated on the basis of suspended-sediment yield at the other sediment stations. Hubbard Brook is a tributary to Schenob Brook (fig. 5) and has a drainage area of $25.8 \mathrm{mi}^{2}$ at the outflow of Mill Pond Dam. Because of the dam, the Hubbard Brook subbasin was assigned a suspendedsediment yield rate of 21 (tons $/ \mathrm{yr}$ ) $/ \mathrm{mi}^{2}$, the same as the Housatonic River near Great Barrington (station 01197500) (which has five dams upstream of the sampling site). The remaining $24.2 \mathrm{mi}^{2}$ of the Schenob Brook subbasin was assigned a suspended-sediment yield rate of 147 (tons $/ \mathrm{yr}$ ) $/ \mathrm{mi}^{2}$, the same as the Konkapot River (station 01198200), because of the presence of soils with a high soil erodibility factor (Hadley, Limerick, Linlithgo, Saco, and Winooski silt loam soils) adjacent to the stream channel (fig. 4) (U.S. Department of Agriculture, Soil Conservation Service, 1970; 1988; 1989). The resulting estimated annual suspended-sediment yield for the Schenob Brook subbasin of 82 (tons/yr) $/ \mathrm{mi}^{2}$ was slightly higher than that of Green River (station 01198000) and Ironworks Brook (station 01198122) (table 9).

Suspended-sediment yield for the area adjacent to the Housatonic River between Great Barrington and Ashley Falls was determined by subtracting the total suspended-sediment discharge for April 1994 through March 1996 of the Housatonic River near Great Barrington (station 01197500), Williams River (station 01197802), Green River (station 01198000), Schenob Brook (station 01198080), and Ironworks Brook (station 01198122) from the total suspended-sediment discharge of Housatonic River near Ashley Falls (station 01198125) (fig. 5), and then dividing the residual suspended-sediment discharge of the area adjacent to the Housatonic River between Great Barrington and Ashley Falls $\left(27.6 \mathrm{mi}^{2}\right)$ by 2 (2 years of record). This area adjacent to the Housatonic River between Great Barrington and Ashley Falls had an estimated suspended-sediment yield of 395 (tons $/ \mathrm{yr}$ ) $/ \mathrm{mi}^{2}$ (table 9). Although, this value is about 2.7 to 18.8 times greater than values for any of the other seven subbasins, it appears reasonable given the significant area of (1) soils with a high soil erodibility (Hadley, Limerick, Linlithgo, Saco, and Winooski silt loam soils) adjacent to the stream channel (fig. 4), (2) agriculture and open land adjacent to the stream channel (fig. 2), and (3) stratified-drift deposits in the subbasin. 


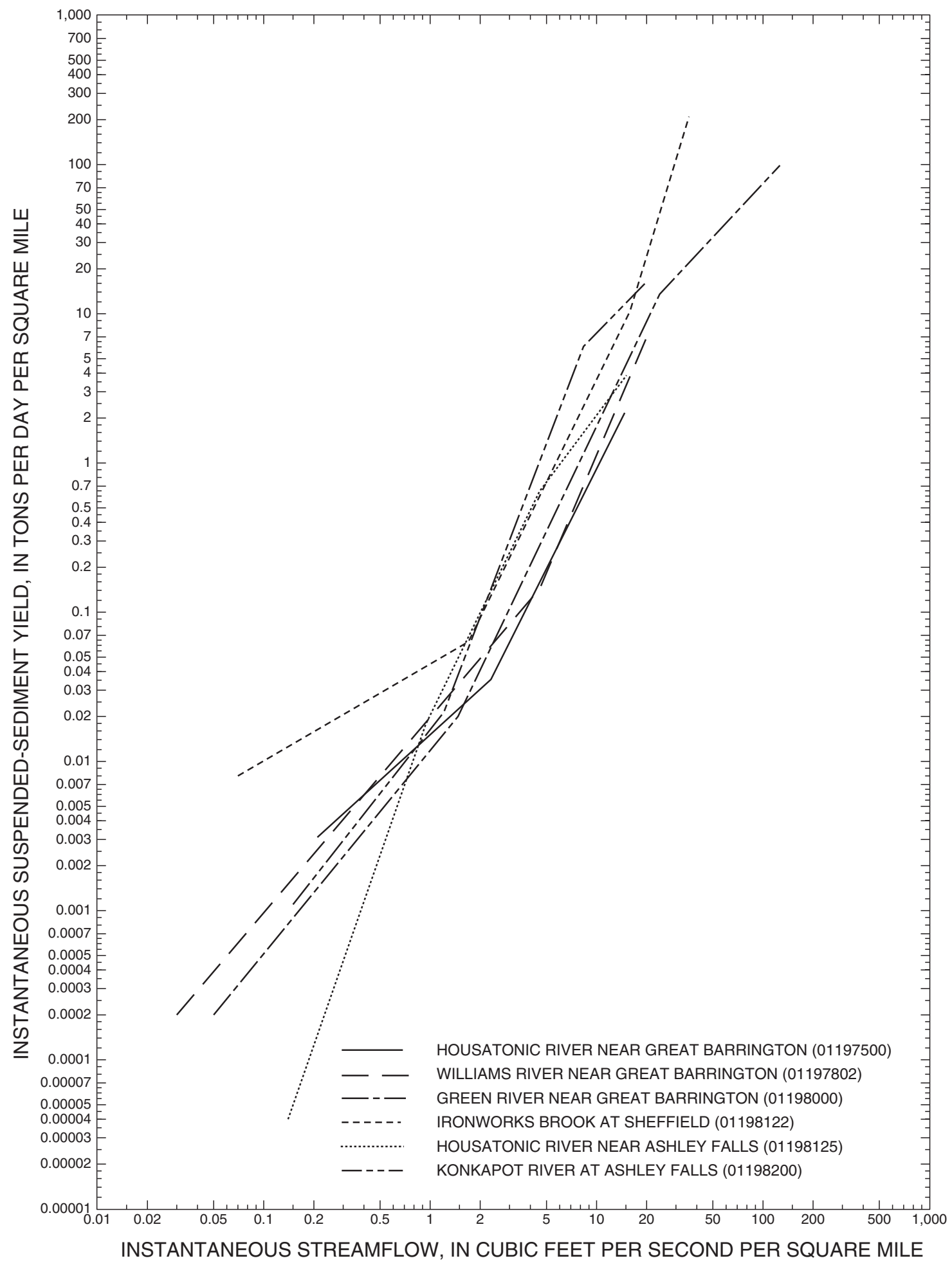

Figure 12. Sediment-transport curves of instantaneous suspended-sediment yield to concurrent streamflow per square mile at six sediment stations in the Housatonic River Basin, western Massachusetts, March 1994 through April 1996. 
Suspended-sediment yields were determined for the Housatonic River near Ashley Falls (station 01198125, $465 \mathrm{mi}^{2}$ ), and the Konkapot River (station $01198200,61.1 \mathrm{mi}^{2}$ ), which drains into the Housatonic River below the Housatonic River near Ashley Falls station, but above the Massachusetts-Connecticut State border (fig. 5). The residual area of the study area draining to the Housatonic River upstream of the Massachusetts-Connecticut State border not covered by the seven sediment stations is $8.9 \mathrm{mi}^{2}$. This residual area is along the Housatonic River downstream from the Housatonic River near Ashley Falls and has similar land use, geology, and highly erodible soils to the area adjacent to the Housatonic River between Great Barrington and Ashley Falls (figs. 2, 3, and 4). The suspended-sediment yield for that part of the study area, $535 \mathrm{mi}^{2}$, draining to the Housatonic River upstream from the Massachusetts-Connecticut State border was estimated to be 74.1 (tons $/ \mathrm{yr}$ ) $/ \mathrm{mi}^{2}$. This estimate excludes $5.0 \mathrm{mi}^{2}$ of the entire study area which drains to the Housatonic River downstream of the Massachusetts-Connecticut State border. This suspended-sediment yield was estimated by dividing the sum of the subbasin suspended-sediment loads for the 2-year study of the Housatonic River near Ashley Falls (54,347 tons, table 7), the Konkapot River $(17,927$ tons, table 6$)$, and the residual area of the study area draining to the Housatonic River upstream from the Massachusetts-Connecticut State border not covered by the 7 sediment stations $(7,031 \text { tons })^{2}$ by 2 years and by the drainage area of the Housatonic River Basin at the Massachusetts-Connecticut state border (about $535 \mathrm{mi}^{2}$ ).

\section{LIMITATIONS OF THE ANALYSIS AT PARTIAL-RECORD SEDIMENT STATIONS}

Colby (1956) and Walling (1977) reported that using transport curves of instantaneous suspendedsediment and concurrent streamflow data with flowduration curves of daily mean streamflow (flow duration, rating-curve method-Miller, 1951) can result in errors in estimates of annual suspended- sediment discharge. Estimates made this way could range from -50 to 200 percent of the true suspendedsediment load (Colby, 1956). Walling (1977) and Yorke and Ward (1986) concluded that the variability of the estimate using a sediment-transport curve and flowduration curve is associated primarily with the scatter of suspended-sediment data associated with the sediment-transport curve (for example, see fig. 10). Several factors could cause an error in the estimate of suspended-sediment discharge (Walling, 1977). Errors could result from sampling techniques, laboratory techniques, poor streamflow data, an inadequate sampling program, and factors related to the dynamics of erosion and sediment-transport processes. Factors related to the dynamics of erosion and sediment-transport processes are the most significant causes of error in estimates of suspendedsediment discharge (Crawford and Mansue, 1996, p. 24). These factors include (1) differences in vegetative cover between seasons (October through March, dormant season; April through September, growing season); (2) differences in water temperature (colder water is more dense and viscous and thus can carry more sediment); (3) effects of hysteresis, in which sediment concentrations are higher during the rising stage of runoff than during the falling stage; (4) differences in the intensity of storms; (5) differences in the distribution and movement of precipitation over the drainage basin; and (6) decreases in suspended-sediment concentrations with successive runoff events due to the depletion of readily erodible material.

To assess the accuracy of the calculations of suspended-sediment discharge, load, and yield at the partial-record sediment station, calculations at continuous-record sediment stations using sedimenttransport curves with a flow-duration curve of daily mean streamflow must be compared to those obtained by summing the daily suspended-sediment discharge for the period of record. This comparison of methods is possible only at continuous-record sediment stations, because summing the daily suspended-sediment discharge is not possible at partial-record sediment stations. This comparison of methods at continuousrecord sediment stations gives an indication of how

\footnotetext{
${ }^{2}$ The value 7,031 tons was calculated by multiplying $8.9 \mathrm{mi}^{2}$ by 2 years by 395 (tons/yr)/mi ${ }^{2}$.
} 
much the estimates of suspended-sediment discharge, load, and yield at partial-record sediment stations might differ from their most accurate estimate if they could be calculated by summing the daily suspendedsediment discharge for the period of record.

Suspended-sediment yield for the three continuous-record sediment stations in the study area from April 1994 through March 1996 were compared using three different methods (table 10). The calculation of suspended-sediment yield at the Housatonic River near Great Barrington (station 01197500) from April 1979 through September 1980 was compared using two of the three different methods (table 10). The three methods were (1) summing the daily suspended-sediment discharges for the period of record [standard method in calculations of suspended-sediment transport at continuous-record stations (Porterfield, 1972, p. 39-56)], (2) using a sediment-transport curve of daily suspended-sediment discharge as a function of daily mean streamflow and a flow-duration curve of daily mean streamflow (flowduration, rating-curve method-Miller, 1951), and (3) using a sediment-transport curve of instantaneous suspended-sediment discharge as a function of concurrent streamflow and a flow-duration curve of daily mean streamflow (flow-duration, rating-curve method-Miller, 1951). Equations for sedimenttransport curves based on daily values (second method) and instantaneous values (third method) in table 5 were determined using the method described previously in the "Calculation of Suspended-Sediment Discharge, Load, and Yield" section.

Estimates of suspended-sediment yield obtained using the second method compared well (within 6 percent) with those obtained using the first method for three of the four tests (table 10). At Green River (station 01198000) estimates obtained using the second method were about 37 percent greater than those obtained using the first method.

Estimates of suspended-sediment yield obtained using the third method produced results that were from about 26 to 35 percent greater than estimates obtained using the first method at the three stations. Thus, estimates of suspended-sediment discharge, load, and yield at the three partial-record sediment stations in the study area may be from 26 to 35 percent greater (positive bias) than estimates that would be obtained if the first method (most accurate estimate) could be applied. Instantaneous suspended-sediment discharge and streamflow data were not available to develop sediment-transport curves for April 1979 through September 1980 at Housatonic River near Great Barrington (station 01197500) to make a comparison between the third method and the first method.

Crawford and Mansue (1996, p. 20-27 and 50) did a similar comparison of these three different methods of determining the limitations of the analysis of suspended-sediment yield at partial-record sediment stations using data from three continuous-record sediment stations in Indiana. Their estimates of suspended-sediment yields obtained using the second method ranged from -23 to 37 percent of those estimates obtained using the first method. Estimates obtained using the third method ranged from -5 to 151 percent of those estimates obtained using the first method. An evaluation of the accuracy of the third method was done using data from six continuousrecord sediment stations in Pennsylvania and Delaware by Yorke and Ward (1986). Estimates of suspendedsediment discharge obtained using the third method ranged from -55 to 132 percent of those estimates obtained using the first method. The comparison of these methods in the study area (table 10) in Indiana (Crawford and Mansue, 1996, p. 20-27 and 50) and in Pennsylvania and Delaware (Yorke and Ward, 1986) demonstrates that estimates of total suspendedsediment discharge obtained using sediment-transport curves with a flow-duration curve of daily mean streamflow at partial-record sediment stations probably results in estimates that are not as accurate as calculations made for continuous-record sediment stations obtained by summing the daily suspendedsediment discharge for the period of record.

Additionally, less-accurate calculations for total suspended-sediment discharge would be expected at partial-record sediment stations where daily mean streamflows were estimated on the basis of oncea-day stream-stage readings and not on continuous (15 minute) stream-stage readings, such as in this study. Although estimates of suspended-sediment discharge for partial-record stations are not as accurate as those that could be obtained for continuous-record stations, data from partial-record stations do provide a reasonable and cost-effective estimate of suspended-sediment discharge. 
Table 10. Comparison of suspended-sediment yield calculated using three methods for the three continuous-record sediment stations in the Housatonic River Basin, western Massachusetts, April 1979 though September 1980 and April 1994 through March 1996

[Sediment-transport curve equations for the three continuous record stations and two time periods are in table 5. USGS station No.: Locations shown in figure 5 and described in table 2. No., number, USGS, U.S. Geological Survey; $\left(\mathrm{ft}^{3} / \mathrm{s}\right) / \mathrm{mi}^{2}$, cubic foot per second per square mile; (ton/yr) $/ \mathrm{mi}^{2}$, ton per year per square mile; --, no data]

\begin{tabular}{|c|c|c|c|c|c|c|c|c|c|}
\hline \multirow{2}{*}{$\begin{array}{l}\text { USGS } \\
\text { station } \\
\text { No. }\end{array}$} & \multirow{2}{*}{ Station name } & \multicolumn{2}{|c|}{$\begin{array}{l}\text { Sum of daily values } \\
\text { (method } 1)\end{array}$} & \multicolumn{3}{|c|}{$\begin{array}{l}\text { Flow-duration and sediment-transport curve } \\
\text { equations using daily suspended-sediment data } \\
\text { (method 2) }\end{array}$} & \multicolumn{3}{|c|}{$\begin{array}{c}\text { Flow-duration and sediment-transport curve } \\
\text { equations using instantaneous } \\
\text { suspended-sediment data } \\
\text { (method 3) }\end{array}$} \\
\hline & & $\begin{array}{c}\text { Total } \\
\text { stream- } \\
\text { flow } \\
\left(\left(\mathrm{ft}^{3} / \mathrm{s}\right) / \mathrm{mi}^{2}\right)\end{array}$ & $\begin{array}{l}\text { Suspended- } \\
\text { sediment } \\
\text { yield } \\
\left((\text { ton } / \mathbf{y r}) / \mathrm{mi}^{2}\right)\end{array}$ & $\begin{array}{c}\text { Total } \\
\text { stream- } \\
\text { flow } \\
\left(\left(\mathrm{ft}^{3} / \mathrm{s}\right) / \mathrm{mi}^{2}\right)\end{array}$ & $\begin{array}{l}\text { Suspended- } \\
\text { sediment } \\
\text { yield } \\
\left((\text { ton/yr }) / \mathrm{mi}^{2}\right)\end{array}$ & $\begin{array}{l}\text { Percent difference } \\
\text { in suspended- } \\
\text { sediment yield from } \\
\text { sum of daily values }\end{array}$ & $\begin{array}{c}\text { Total } \\
\text { streamflow } \\
\left(\left(\mathrm{ft}^{3} / \mathrm{s}\right) / \mathrm{mi}^{2}\right)\end{array}$ & $\begin{array}{l}\text { Suspended- } \\
\text { sediment } \\
\text { yield } \\
((\text { ton/yr)/mi²) }\end{array}$ & $\begin{array}{l}\text { Percent difference } \\
\text { in suspended- } \\
\text { sediment yield from } \\
\text { sum of daily values }\end{array}$ \\
\hline \multicolumn{10}{|c|}{ April 1994 Through March 1996} \\
\hline 01197500 & $\begin{array}{l}\text { Housatonic River near } \\
\text { Great Barrington }\end{array}$ & 694 & 20.6 & 694 & 21.0 & +1.94 & 694 & 27.9 & +35.4 \\
\hline 01198000 & Green River near Great Barrington & 699 & 77.7 & 709 & 106.2 & +36.7 & 709 & 97.8 & +25.9 \\
\hline 01198125 & $\begin{array}{l}\text { Housatonic River near } \\
\text { Ashley Falls }\end{array}$ & 711 & 58.4 & 715 & 61.9 & +5.99 & 715 & 75.5 & +29.3 \\
\hline \multicolumn{10}{|c|}{ April 1979 Through September 1980} \\
\hline 01197500 & $\begin{array}{l}\text { Housatonic River near } \\
\text { Great Barrington }\end{array}$ & 635 & 25.3 & 638 & 24.6 & -2.77 & -- & -- & -- \\
\hline
\end{tabular}


The relative suspended-sediment yields at Housatonic River near Great Barrington (station 01197500), Green River (station 01198000), and Housatonic River near Ashley Falls (station 01198125) calculated using the three methods compared well between the three stations (table 10). Suspendedsediment yields at Green River and Housatonic River near Ashley Falls, calculated using the first method, were 3.8 and 2.8 times higher than yields at Housatonic River near Great Barrington. For the second method, suspended-sediment yields were 5.1 and 2.9 times higher, and for the third method, suspended-sediment yields were 3.5 and 2.7 times higher.

\section{FACTORS AFFECTING SUSPENDED-SEDIMENT YIELD}

Hydrologic, physical, and land-use characteristics of the subbasins in the study area were evaluated to explain differences in suspendedsediment yield between the six measured subbasins and two estimated subbasins [Schenob Brook (station 01198080) and the area adjacent to the Housatonic River between Great Barrington and Ashley Falls] (table 9). Characteristics considered in the evaluation were dams, total streamflow, soils, surficial geology, bedrock geology, mean basin slope, area of forest, area of agricultural and open land, area of mining and barren land, area of forested and non-forested wetlands, and area of water bodies. Differences in precipitation were not evaluated because precipitation data were not available in all study subbasins; however, total streamflow from the six measured subbasins was evaluated (table 9). Differences in soils between the eight subbasins were evaluated by determining the area of soils reported to have a high soil erodibility factor (K-factor) from digital data bases of soil survey maps (U.S. Department of Agriculture, Soil Conservation Service, 1970; 1988; 1989).

\section{Dams}

The suspended-sediment yield at the Housatonic River near Great Barrington (station 01197500) was the lowest of the eight subbasins. The basin and landuse characteristics were compared and found to be similar to those of other subbasins. The only notable difference is that upstream from the Housatonic River near Great Barrington station are five major dams (fig. 5), including the Rising Pond Dam, which is only about $0.8 \mathrm{mi}$ upstream. The five dams most likely trap sediments that would have otherwise been discharged to the Housatonic River near Great Barrington.

Woods Pond Dam and Rising Pond Dam are the only two dams on the Housatonic River that have substantial impoundments (fig. 5). Woods Pond has a surface area of about $0.19 \mathrm{mi}^{2}$ and depths of $15 \mathrm{ft}$ (Frink and others, 1982). Rising Pond has a surface area of about $0.07 \mathrm{mi}^{2}$ and depths of $15 \mathrm{ft}$. Frink and others (1982) also report that sediment thicknesses in Woods Pond ranged from 0.5 to $6 \mathrm{ft}$ and ranged from 6 to $8 \mathrm{ft}$ in Rising Pond. These sediment thicknesses indicate that the two dams trap sediments that otherwise would have been discharged downstream. Although the impoundments associated with other three dams - Columbia Mill, Willow Mill, and Glendale - are not as large as the Woods Pond Dam and Rising Pond Dam, they too trap sediment that otherwise would have been discharged downstream.

Dams also may increase sediment transport downstream. As a dam traps sediment, the stream below the dam may become sediment starved, which can result in scouring of the streambed and stream banks. Thus, the scouring equilibrates the stream's sediment carrying capacity by increasing bedload transport (Collier and others, 1996).

\section{Soils}

The area adjacent to the Housatonic River between Great Barrington and Ashley Falls subbasin (fig. 4 and table 9) had the largest percentage of soils with a high soil-erodibility factor (20 percent). This subbasin also had the highest percentage of the Hadley, Limerick, Saco, and Winooski silt loam soils individually. The correlation coefficient of percent area of soils with a high soil erodibility to suspendedsediment yield was 0.93 , and is mainly affected by the area adjacent to the Housatonic River between Great Barrington and Ashley Falls subbasin [which had a higher percentage of high soil erodibility and the highest suspended-sediment yield as compared to other subbasins (table 9)]. This subbasin also affected the correlation coefficients of the percent area of Hadley, Limerick, Saco, and Winooski silt loam soils to 
suspended-sediment yield $(0.95,0.89,0.66$, and 0.93 , respectively) again with its much higher percent area of these soils and suspended-sediment yield than the other subbasins. Although these correlation coefficients are mainly affected by this subbasin, they seem reasonable given visual observations of (1) streambank sloughing along the Housatonic River in areas of these silt loam soils, and (2) the Housatonic River out of its banks and flowing across areas of these soils several times during the 2-year study.

The Schenob Brook (station 01198080) subbasin has the second highest percentage of soils with a high soil erodibility, but had an estimated suspendedsediment yield close to Green River (station 01198000) (third lowest percentage of these soils) and Ironworks Brook (station 01198122) (lowest percentage of these soils) subbasin (table 9). This is likely the result of the dam on Hubbard Brook in the Schenob Brook subbasin and the backwater conditions during moderate to high flows at the Schenob Brook station. The Housatonic River near Great Barrington had the fourth highest percentage of soils with a high soil erodibility (table 9), but the lowest suspended-sediment yield likely because of the five dams on the Housatonic River as previously discussed.

\section{Geology}

To assess the possible effects of geology on suspended-sediment yield in the study area, the percent area of stratified-drift deposits (surficial geology) and carbonate rocks (bedrock geology), were compared for the eight subbasins. The percent area of carbonate rocks was chosen to represent the effects of bedrock geology, because carbonate rocks weather more readily than schistose or gneissic and quartzitic rocks.

The suspended-sediments yield in a subbasin generally increased with increasing percent area of stratified-drift deposits present (table 9). Percent area of stratified-drift deposits was highly related to suspended-sediment yield, and the correlation coefficient was 0.86 for the eight subbasins. This high correlation was mainly the result of the estimated high suspended-sediment yield and high percent area of stratified-drift deposits for the area adjacent to the Housatonic River between Great Barrington and Ashley Falls. The subbasins for the area adjacent to the Housatonic River between Great Barrington and Ashley Falls and the Konkapot River (station
01198200) had the highest and second highest suspended-sediment yields and percent area of stratified-drift deposits, respectively, excluding Schenob Brook (station 01198080) (high percent area of stratified-drift deposits but only a moderate estimate of suspended-sediment yield due to a dam on its major tributary Hubbard Brook). These two subbasins (area adjacent to the Housatonic River between Great Barrington and Ashley Falls and the Konkapot River) are in the southern part of the basin (fig. 3), where stratified-drift deposits are generally of glaciolacustrine origin, as previously mentioned. These glaciolacustrine deposits (generally clay, silt, and fine sand) are related to the Hadley, Limerick, Lithligo, Saco, and Winooski silt loam soils (high soil-erodibility factor); the correlation coefficient between percent area of stratified-drift deposits and percent area of soils with high soilerodibility factor was 0.95 for the eight subbasins. Differences in the percent area of carbonate rocks varied among the subbasins (34.5 to 69.4 percent, table 9), and did not strongly relate to differences in suspended-sediment yield ( 0.28 correlation coefficient).

\section{Land Use}

Land uses were evaluated for their potential to affect the suspended-sediment yield in the study area. Land uses evaluated were the percent area of (1) agricultural and open, (2) barren, (3) water bodies, (4) forested wetlands, and (5) non-forested wetlands. Areas of agricultural, open, and barren land likely cause an increase suspended-sediment yield (relative to other areas) because these areas generally have greater percentage of bare soil and (or) greater soil disturbances than other areas. Water bodies, forested wetland, and non-forested wetlands act as sediment traps and thus tend to decrease suspended-sediment yield from an area.

The percentage of agricultural and open land was highest in the area adjacent to the Housatonic River between Great Barrington and Ashley Falls subbasin, where suspended-sediment yield was also highest among the eight subbasins (fig. 2 and table 9). The correlation coefficient of percent area of agricultural and open land to suspended-sediment yield was 0.86 and is mainly affected by the area adjacent to the Housatonic River between Great Barrington and 
Ashley Falls subbasin. Tillage and exposure of the soil during the dormant (nongrowing) season provides a source of erodible material. Most of the agricultural and open land in the area adjacent to the Housatonic River between Great Barrington and Ashley Falls (fig. 2) is on the flood plain of the Housatonic River. The flood plain area, which contains most of the agricultural and open land along the Housatonic River, typically is inundated when the Housatonic River flows over its banks. The Housatonic River was observed out of its banks and flowing across agricultural areas on bends in the river in the subbasin of the region adjacent to the Housatonic River between Great Barrington and Ashley Falls several times during the 2-year study. Most areas mapped as the Hadley, Limerick, Linlithgo, Saco, and Winooski silt loam soils (fig. 4), which are mainly found in the area adjacent to the Housatonic River between Great Barrington and Ashley Falls, are cleared and used for crops, hay, and pasture (U.S. Department of Agriculture, Soil Conservation Service, 1988, p. 13). The correlation coefficient between agricultural and open land and soil types with a high soil-erodibility factor was 0.85 . Runoff from drainage basins mainly having agricultural land use were reported to have the second highest suspendedsediment concentration of the four general land uses (agricultural, urban, forest, and range) in the United States (Zimmerman and others, 1996, p. 75).

The percent area of barren differed slightly among the subbasins ( 0.62 to 2.94 percent, table 9 ) and did not strongly relate to differences in suspendedsediment yield ( 0.20 correlation coefficient). The combined percent areas of water bodies, forested wetlands, and nonforested wetlands differed among the subbasins (3.0 to 12.9 percent, table 9) and was negatively related to differences in suspended-sediment yield (-0.50 correlation coefficient). Water bodies, forested wetlands, and nonforested wetlands likely are efficient in trapping sediment much like the five reservoirs (dams) on the main stem of the Housatonic River upstream from the continuous-record sediment station near Great Barrington (01197500) (fig. 5).

\section{Other Factors}

Differences in total streamflow (table 9) and in streamflow characteristics (flow durations) (fig. 7) were evaluated for their effect on differences in suspended-sediment yield among the eight subbasins.
Although total streamflows differed among the eight subbasins (table 9), the differences did not strongly relate to the differences observed in suspendedsediment yields (correlation coefficient -0.14). Comparisons of flow-duration curves on a per-squaremile basis for the 2-year study found slight differences in streamflow characteristics among subbasins, but the differences did not appear to relate to differences in suspended-sediment yield.

Mean basin slope was evaluated for each of the eight subbasins, because steeper slope increases potential soil erosion (Wischmeier and Smith, 1978). Mean basin slope differed slightly among the subbasins (6.78 to 9.49 percent, table 9 ) and did not strongly relate to differences in suspended-sediment yield (correlation coefficient -0.27).

\section{COMPARISON TO RESULTS OF OTHER SUSPENDED-SEDIMENT STUDIES IN THE NORTHEASTERN UNITED STATES}

Median instantaneous suspended-sediment concentrations at the Housatonic River near Great Barrington (station 01197500), Williams River (station 01197802), Green River (station 01198000), and Schenob Brook (station 01198080) (7 to $10 \mathrm{mg} / \mathrm{L}$, table 4) were from 0.7 to 2.5 times those reported for five suspended-sediment stations in Connecticut and one station in New Hampshire (4 to $10 \mathrm{mg} / \mathrm{L}$ ) by Zimmerman and others (1996, p. 75) and from 1.8 to 5.0 times those reported for two other suspendedsediment stations in Connecticut ( 2 and $4 \mathrm{mg} / \mathrm{L}$, respectively) by Kulp (1983, p. 14 and 15; 1991b, p. 13 and 14). Median concentrations at Ironworks Brook (station 01198122), Housatonic River near Ashley Falls (station 01198125), and Konkapot River (station 01198200) (table 4) were greater (1.6 to 15 times) than the eight stations reported by Zimmerman and others (1996, p. 75) and Kulp (1983, p. 14 and 15; 1991b, p. 13 and 14). As stated previously, median instantaneous sediment concentrations at Ironworks Brook and Konkapot River could be higher than at the other stations because the median instantaneous streamflow sampled at these two stations also was higher than the other stations in the study area.

Suspended-sediment yield for the eight subbasins in the study area ranged from 21 to 395 (tons $/ \mathrm{yr}) / \mathrm{mi}^{2}$ (table 9). These values for the 
study area compared well to suspended-sediment yields for four continuous-record sediment stations in Connecticut: the Yantic River in east-central Connecticut, 43.5 (tons/yr) $/ \mathrm{mi}^{2}$ (Kulp, 1983, p. 20); Muddy Brook in northeast Connecticut, 32.5 (tons/yr)/mi ${ }^{2}$ (Kulp, 1991b, p. 19); the Coginchaug River in south-central Connecticut, 29.3 (tons/yr) $/ \mathrm{mi}^{2}$ (Morrison, 1998); and the Salmon River, 276 (tons/yr) $/ \mathrm{mi}^{2}$ (Morrison, 1998). The drainage basins of the four continuous-record sediment stations in Connecticut were glaciated. Suspendedsediment yields in the study area also compared well to suspended-sediment yields in the glaciated area of the Susquehanna River Basin in south-central New York and north-central Pennsylvania (Williams and Reed, 1972, p. F5-F10), where suspended-sediment yields ranged from 40 to 440 (tons/yr) $/ \mathrm{mi}^{2}$ for 19 sediment stations.

\section{SUMMARY AND CONCLUSIONS}

Suspended-sediment concentrations, discharges, loads, and yields were determined for eight subbasins in the Housatonic River Basin in western Massachusetts, eastern New York, and northwestern Connecticut from April 1994 through March 1996. Information on suspended sediment is important in the Housatonic River Basin because selected water-quality constituents have a strong relation to sediments. Additionally, a better understanding of suspendedsediment characteristics is needed for evaluating human uses [such as recreation (aesthetics), potential sedimentation of reservoirs, lakes, and ponds, designing water-treatment plants, and designing reservoirs] as well as for maintaining stream habitat for fish and wildlife.

Suspended-sediment concentration samples were collected from 271 to 329 times at three continuousrecord stations and from 7 to 158 times at four partialrecord sediment stations during the 2-year study. Suspended-sediment concentrations in samples collected ranged from less than 0.5 to $3,400 \mathrm{mg} / \mathrm{L}$ for concurrent streamflows ranging from 0.03 to $126\left(\mathrm{ft}^{3} / \mathrm{s}\right) / \mathrm{mi}^{2}$. Median suspended-sediment concentrations in samples collected ranged from 7 to $61 \mathrm{mg} / \mathrm{L}$ for concurrent median streamflows ranging from 1.86 to $5.88\left(\mathrm{ft}^{3} / \mathrm{s}\right) / \mathrm{mi}^{2}$. Instantaneous suspendedsediment yields ranged from less than 0.005 to
185 (tons $/ \mathrm{d}) / \mathrm{mi}^{2}$ and medians ranged from 0.03 to 1.12 (tons $/ \mathrm{d}) / \mathrm{mi}^{2}$ at the seven sediment stations. Suspended-sediment samples collected during the 2year study represent almost the entire range of streamflows at the sediment stations.

Total suspended-sediment load for the 2-year study was calculated by summing total daily suspended-sediment discharge at the three continuousrecord sediment stations. Total suspended-sediment loads at these sediment stations were 11,603 tons at Housatonic River near Great Barrington (station 01197500), 7,929 tons at Green River (station 01198000), and 54,347 tons at Housatonic River near Ashley Falls (station 01198125). From 35 to 76 percent of the total suspended sediment was discharged during 1 percent of the time at the three continuous-record sediment stations, and from 93 to 99 percent of the total suspended sediment was discharged during 10 percent of the time. The load for January 1996 accounted for about 54 percent of the total suspendedsediment load in the Green River subbasin during the 2-year study. The load for January 19 and 20, 1996 accounted for about 50 percent of the January 1996 load or about 27 percent of the total suspendedsediment load in the Green River subbasin during the 2-year study. This was the result of rainfall and snowmelt on January 19 and 20, 1996 that was equivalent to 5 to 6 in. of rainfall in the Green River subbasin.

Suspended-sediment yields at the three continuous-record sediment stations were 21 (tons/yr) $/ \mathrm{mi}^{2}$ at Housatonic River near Great Barrington (station 01197500), 78 (tons/yr) $/ \mathrm{mi}^{2}$ at Green River (station 01198000), and 58 (tons/yr) $/ \mathrm{mi}^{2}$ at Housatonic River near Ashley Falls (station 01198125). Suspended-sediment yield at the Housatonic River near Great Barrington, 21 (tons/yr)/mi ${ }^{2}$ from April 1994 through March 1996, compared well to the yield for a previous study, 25 (tons/yr)/mi² from April 1979 through September 1980. Sediment-transport curves that relate daily suspended-sediment discharge to daily mean streamflow indicated that throughout the range of streamflows, daily suspended-sediment discharge was higher from April 1979 through September 1980 than from April 1994 through March 1996.

Total suspended-sediment load for the 2-year study was calculated by using sediment-transport curves in which instantaneous suspended-sediment discharge is plotted against concurrent streamflow, 
with flow-duration curves of daily mean streamflow at the three partial-record sediment stations. Total suspended-sediment loads at these sediment stations were 3,052 tons at Williams River (station 01197802), 1,758 tons at Ironworks Brook (station 01198122), and 17,927 tons Konkapot River (station 01198200). From 29 to 36 percent of the total suspended sediment was discharged during 1 percent of the time at the three partial-record sediment stations and from 78 to 87 percent of the total suspended sediment was discharged during 10 percent of the time. Suspended-sediment yields at the three partial-record sediment stations were 35 (tons/yr) $/ \mathrm{mi}^{2}$ at Williams River, 78 (tons $/ \mathrm{yr}$ ) $/ \mathrm{mi}^{2}$ at Ironworks Brook, and 147 (tons/yr)/mi ${ }^{2}$ at Konkapot River.

Suspended-sediment yield was estimated for two subbasins [the partial-record sediment station Schenob Brook (01198080) and the area adjacent to the Housatonic River between Great Barrington and Ashley Falls] in the study area. The estimate for Schenob Brook was based on suspended-sediment yields at the Housatonic River near Great Barrington (station 01197500) and the Konkapot River (station 01198200). The estimate of suspended-sediment yield at Schenob Brook was 82 (tons/yr) $/ \mathrm{mi}^{2}$, and compared well with estimates of suspended-sediment yield at Green River (station 01198000) and Ironworks Brook (station 01198122). The estimated yield for the area adjacent to the Housatonic River between Great Barrington and Ashley Falls was 395 (tons/yr)/mi ${ }^{2}$. This estimated suspended-sediment yield was 2.7 to 18.8 times greater than that observed in any of the other subbasins. Suspended-sediment yield estimated for that part of the study area, $535 \mathrm{mi}^{2}$, draining to the Housatonic River upstream from the MassachusettsConnecticut State border was 74.1 (tons $/ \mathrm{yr}$ ) $/ \mathrm{mi}^{2}$. This estimate excludes $5.0 \mathrm{mi}^{2}$ of the entire study area which drains to the Housatonic River downstream of the Massachusetts-Connecticut State border.

Calculations of suspended-sediment discharge, loads, and yield at partial-record sediment stations Williams River (01197802), Ironworks Brook (01198122), and Konkapot River (01198200) may be less accurate than calculations for the three continuousrecord sediment stations, because the method used was less accurate. Additionally, daily mean streamflows at these partial-record sediment stations were estimated on the basis of once-a-day stream-stage readings and not continuous (15 minute) stream-stage readings. The estimates of suspended-sediment discharge and yield seem reasonable when compared to those for the three continuous-record sediment stations; however, the estimates could be about 30 percent greater than the three continuous-record sediment stations.

Several basin and land-use characteristics, thought to affect suspended-sediment discharge in the subbasins, were compared to the suspended-sediment yields. The characteristics that appeared to affect suspended-sediment discharge were dams (decrease), Hadley, Limerick, Linlithgo, Saco, and Winooski silt loam soils (high-erodibility soils) (increase), stratifieddrift deposits (increase), and agricultural and open land (increase). The affect of stratified-drift deposits on suspended-sediment discharge were thought to be greater when the stratified-drift deposits were glaciolacustrine deposits (generally clay, silt, and fine sand). These three factors (glaciolacustrine deposits; the Hadley, Limerick, Linlithgo, Saco, and Winooski silt loam soils; and agricultural and open land) were interrelated inasmuch as the Hadley, Limerick, Linlithgo, Saco, and Winooski soils tended to be associated with glaciolacustrine deposits, and agricultural activities tended to be on Hadley, Limerick, Linlithgo, Saco, and Winooski soils. For example, the area adjacent to the Housatonic River between Great Barrington and Ashley Falls, which had the highest suspended-sediment yield of the eight subbasins, had the highest percent area of Hadley, Limerick, Linlithgo, Saco, and Winooski silt loam soils and agricultural and open land; and the second highest percent area of stratified-drift deposits.

Median suspended-sediment concentrations for four sediment stations in the study area were from 0.7 to 5.0 times those reported at seven sediment stations in Connecticut and one sediment station in New Hampshire. Ironworks Brook (station 01198122), Housatonic River near Ashley Falls (station 01198125), and Konkapot River (station 01198200) had higher (from 1.6 to 15 times greater) median suspendedsediment concentrations than these other stations in Connecticut and New Hampshire. Suspended-sediment yields for the 8 subbasins of the study area compared well to suspended-sediment yields in glaciated areas (4 sediment stations in Connecticut and 19 sediment stations in New York and Pennsylvania). 


\section{REFERENCES CITED}

Bent, G.C., 1999, Streamflow, baseflow, and ground-water recharge in the Housatonic River Basin, western Massachusetts: U.S. Geological Survey WaterResources Investigations Report 98-4232, 68 p.

Bickford, W.E., and Dymon, U.J., 1990, An atlas of Massachusetts river systems, environmental design for the future: Amherst, Mass., University of Massachusetts Press, $87 \mathrm{p}$.

Breault, R.F., and Harris, S.L., 1997, Geographical distribution and potential for adverse biological effects of selected trace elements and organic compounds in streambed sediment in the Connecticut, Housatonic, and Thames River Basins, 1992-94: U.S. Geological Survey Water-Resources Investigations Report $97-$ 4169, 24 p.

Cleveland, W.S., 1979, Robust locally weighted regression and smoothing scatterplots: Journal of American Statistics Association, v. 74, p. 829-836.

Colby, B.R., 1956, Relationship of sediment discharge to streamflow: U.S. Geological Survey Open-File Report, $170 \mathrm{p}$.

Collier, Michael, Webb, R.H., and Schmidt, J.C., 1996, Dams and rivers-A primer on the downstream effects of dams: U.S. Geological Survey Circular 1126, 94 p.

Crawford, C.G., 1991, Estimation of suspended-sediment rating curves and mean suspended-sediment loads: Journal of Hydrology, v. 129, p. 331-348.

Crawford, C.G., and Mansue, L.J., 1996, Suspendedsediment characteristics of Indiana streams, 1952-84: U.S. Geological Survey Water-Supply Paper 2404, 55 p.

Duan, Naihua, 1983, Smearing estimate-A nonparametric retransformation method: Journal of the American Statistical Association, v. 78, p. 605-610.

Edwards, T.K., and Glysson, G.D., 1999, Field methods for measurement of fluvial sediment: U.S. Geological Survey Techniques of Water-Resources Investigations Report, Chap. C2, book 3, 89 p.

Farr, I.S., and Clarke, R.T., 1984, Reliability of suspended load estimates in chalk streams: Archiv fur Hydrobiologie, v. 101, p. 1-19.

Ferguson, R.I., 1986, River loads underestimated by rating curves: Water Resources Research, v. 22, no. 1, p. 7476.

Frink, C.R., Sawhney, B.L., Kulp, K.P., and Fredette, C.G., 1982, Polychlorinated biphenyls in Housatonic River sediments in Massachusetts and ConnecticutDetermination, distribution, and transport: The Connecticut Agricultural Experiment Station Bulletin 800,20 p.
Gay, F.B., and Frimpter, M.H., 1985, Distribution of polychlorinated biphenyls in the Housatonic River and adjacent aquifer, Massachusetts: U.S. Geological Survey Water-Supply Paper 2266, 26 p.

General Electric Company, 1991, Proposal for interim measure 12-Evaluation of dams along the Housatonic River: Pittsfield, Mass., Submitted to U.S. Environmental Protection Agency, variously paged.

Glysson, G.D., 1987, Sediment-transport curves: U.S. Geological Survey Open-File Report 87-218, 47 p.

Graf, J.B., Wirt, Laurie, Swanson, E.K., Fisk, G.G., and Gray, J.R., 1996, Streamflow transport of radionuclides and other chemical constituents in the Puerco and Little Colorado River Basins, Arizona and New Mexico: U.S. Geological Survey Water-Supply Paper 2459, 89 p.

Harris, S.L., 1997, Inorganic and organic constituents and grain-size distribution in streambed sediment and ancillary data for the Connecticut, Housatonic, and Thames River Basins study unit, 1992-94: U.S. Geological Survey Open-File Report 96-397, 39 p.

Helsel, D.R., and Hirsch, R.M., 1992, Statistical methods in water resources: New York, Studies in Environmental Science 49, Elsevier Science Publishers, 522 p.

Knott, J.M., Glysson, G.D., Malo, B.A., and Schroder, L.J., 1993, Quality assurance plan for the collection and processing of sediment data by the U.S. Geological Survey, Water Resources Division: U.S. Geological Survey Open-File Report 92-499, 18 p.

Knott, J.M., Sholar, C.J., and Matthes, W.J., 1992, Quality assurance guidelines for the analysis of sediment concentration by U.S. Geological Survey sediment laboratories: U.S. Geological Survey Open-File Report 92-33, $30 \mathrm{p}$.

Koch, R.W., and Smillie, G.M., 1986, Bias in hydrologic prediction using log-transformed regression models: Water Resources Bulletin, v. 22, no. 5, p. 717-732.

Koltun, G.F., Gray, J.R., and McElhorne, T.J., 1994, User's manual for SEDCALC, a computer program for computation of suspended-sediment discharge: U.S. Geological Survey Open-File Report 94-459, 46 p.

Kulp, K.P., 1983, Suspended-sediment characteristics of the Yantic River at Yantic, Connecticut: Connecticut Water Resources Bulletin 39, 34 p.

1991a, Concentration and transport of polychlorinated biphenyls in the Housatonic River between Great Barrington, Massachusetts, and Kent, Connecticut, 1984-88: U.S. Geological Survey WaterResources Investigations Report 91-4014, 12 p.

1991b, Suspended-sediment characteristics of Muddy Brook at Woodstock, Connecticut: Connecticut Water Resources Bulletin 43, 64 p. 
Kulp, K.P., and Gay, F.B., 1986, Polychlorinated biphenyls in the Housatonic River, in Proceedings of the Fourth Federal Interagency Sedimentation Conference: Las Vegas, Nev., March 24-27, 1986, v. 2, p. 7-31-7-40.

MassGIS, 1997, MassGIS data layer descriptions and guide to user services: Boston, Mass., MassGIS Executive Office of Environmental Affairs, $131 \mathrm{p}$.

Matthes, W.J., Sholar, C.J., and George, J.R., 1991, Quality assurance plan for the analysis of fluvial sediment by laboratories of the U.S. Geological Survey: U.S. Geological Survey Open-File Report 91-469, 31 p.

Miller, C.R., 1951, Analysis of flow-duration sediment rating curve method of computing sediment yield: U.S. Bureau of Reclamation, 55 p.

Morrison, Jonathan, 1998, Suspended-sediment loads and yields in the Salmon and Coginchaug River Basins, central Connecticut: U.S. Geological Survey Fact Sheet FS-129-98, 4 p.

Norvitch, R.F., 1966, Ground-water favorability map of the Housatonic River Basin, Massachusetts: U.S. Geological Survey, 1 map.

Norvitch, R.F., Farrell, D.F., Pauszek, F.H., and Petersen, R.G., 1968, Hydrology and water resources of the Housatonic River Basin, Massachusetts: U.S. Geological Survey Hydrologic Investigations Atlas HA281, 4 sheets, scale 1:125,000.

Norvitch, R.F., and Lamb, M.E.S., 1966, Records of selected wells, springs, test holes, materials tests, and chemical analyses of water in the Housatonic River Basin, Massachusetts: U.S. Geological Survey Open-File Report 66-93, Massachusetts Basic-Data Report No. 9, Ground-Water Series, 40 p. 1 pl.
Porterfield, George, 1972, Computation of fluvial-sediment discharge: U.S. Geological Survey Techniques of Water-Resources Investigations, book 3, chap. C3, 66 p.

Rantz, S.E., and others, 1982, Measurement and computation of streamflow-Volume 1. Measurement of stage and discharge. Volume 2. Computation of discharge: U.S. Geological Survey Water-Supply Paper $2175,631 \mathrm{p}$.

Robinson, G.R., Jr., Peper, J.D., Steeves, P.A., and DeSimone, L.A., 1999, Lithogeochemical character of near-surface bedrock in the Connecticut, Housatonic, and Thames River Basins: U.S. Geological Survey Digital Water-Resources Investigations Report 99-4000, accessible on the World Wide Web at http://water.usgs.gov/lookup/get?wrir994000.

Searcy, J.K., 1959, Flow-duration curves, manual of hydrology—part 2, low-flow techniques: U.S. Geological Survey Water-Supply Paper 1542-A, p. 133.

Simcox, A.C., 1992, Water resources of Massachusetts: U.S. Geological Survey Water-Resources Investigations Report 90-4144, 94 p.

Simmons, C.E., 1993, Sediment characteristics of North Carolina: U.S. Geological Survey Water-Supply Paper 2364, 84 p.

Socolow, R.S., Comeau, L.Y., Casey, R.G., and Ramsbey, L.R., 1996, Water resources data Massachusetts and Rhode Island, water year 1995: U.S. Geological Survey Water-Data Report MA-RI-95-1, 428 p. 
Socolow, R.S., Murino, Domenic, Jr., Casey, R.G., and Ramsbey, L.R., 1997, Water resources data Massachusetts and Rhode Island, water year 1996: U.S. Geological Survey Water-Data Report MA-RI-96-1, 367 p.

U. S. Department of Agriculture, Soil Conservation Service, 1970, Soil survey of Litchfield County, Connecticut: Soil Conservation Service, 105 p. 1988, Soil survey of Berkshire County, Massachusetts: Soil Conservation Service, 216 p. 1989, Soil survey of Columbia County, New York: Soil Conservation Service, 266 p.

U.S. Department of Commerce, National Atmospheric and Oceanic Administration, 1983, Climatological data annual summary: New England 1983, v. 95, no. 13, $38 \mathrm{p}$.

1993, Climatological data annual summary: New England 1993, v. 105, no. 13, 50 p.

U.S. Geological Survey, 1981, Water resources data for Massachusetts and Rhode Island, water year 1980: U.S. Geological Survey Water-Data Report MA-RI-80-1, $356 \mathrm{p}$.

1991, Programs and plans_-guidelines for the analysis of sediment data: U.S. Geological Survey, Office of Surface Water Technical Memorandum 91.15, $30 \mathrm{p}$.

1992, Recommendations for use of retransformation methods in regression models used to estimate sediment loads ("the bias correction problem"): U.S. Geological Survey, Office of Surface Water Technical Memorandum 93.08, $13 \mathrm{p}$.
Walling, D.E., 1977, Assessing the accuracy of suspendedsediment rating curves for a small basin: Water Resources Research, v. 13, no. 3, p. 531-538.

Wandle, S.W., and Lippert, R.G., 1984, Gazetteer of hydrologic characteristics of streams in Massachusetts-Housatonic River Basin: U.S. Geological Survey Water-Resources Investigations Report 84-4285, 30 p.

Warren, C.R., and Stone, B.D., 1986, Deglaciation stratigraphy, mode and timing of the eastern flank of the Hudson-Champlain Lobe in western Massachusetts, in Cadwell, D.H. (ed.), The Wisconsinan Stage of the First Geological District, eastern New York: Albany, N.Y., New York State Museum Bulletin 455, June 1986, p. 168-192.

Williams, K.F., and Reed, L.A., 1972, Appraisal of stream sedimentation in the Susquehanna River Basin: U.S. Geological Survey Water-Supply Paper 1532-F, 24 p.

Wischmeier, W.H., and Smith, D.D., 1978, Predicting rainfall erosion losses-A guide to conservation planning: U.S. Department of Agriculture Handbook 537, $58 \mathrm{p}$.

Yorke, T.H., and Ward, J.R., 1986, Accuracy of sediment discharge estimates, in Proceedings of the Fourth Federal Interagency Sedimentation Conference: Las Vegas, Nev., March 24-27, 1986, v. 1, p. 4-49-4-59.

Zimmerman, M.J., Grady, S.J.,Todd Trench, E.C., Flanagan, S.M., and Nielsen, M.G., 1996, Water-quality assessment of the Connecticut, Housatonic, and Thames River Basins study unit-Analysis of available data on nutrients, suspended sediments, and pesticides, 1972-92: U.S. Geological Survey Water-Resources Investigations Report 95-4203, 162 p., 1 pl. 

APPENDIXES 

Appendix 1. Daily mean streamflow at partial-record sediment stations in the Housatonic River Basin, western Massachusetts, March 1994 through April 1996

[Locations shown in fig. 5 and described in table 2. MAX, maximum; MIN, minimum; CFSM, cubic feet per second per square mile; IN., inch; ---, not applicable]

01197802 WILLIAMS RIVER, AT RAILROAD BRIDGE, NEAR GREAT BARRINGTON, MA DISCHARGE, CUBIC FEET PER SECOND, WATER YEAR OCTOBER 1993 TO SEPTEMBER 1994 DAILY MEAN VALUES

\begin{tabular}{|c|c|c|c|c|c|c|c|c|c|c|c|c|}
\hline DAY & OCT & NOV & DEC & JAN & FEB & MAR & APR & MAY & JUN & JUL & AUG & SEP \\
\hline 1 & --- & --- & --- & --- & --- & --- & $\mathrm{e} 240$ & e125 & e46 & e27 & $\mathrm{e} 21$ & 20 \\
\hline 2 & --- & --- & --- & --- & --- & --- & e200 & e130 & e45 & 25 & 19 & e18 \\
\hline 3 & --- & --- & --- & --- & --- & --- & $\mathrm{e} 170$ & e110 & e43 & 22 & 15 & e18 \\
\hline 4 & --- & --- & --- & --- & --- & --- & e145 & e96 & e41 & 21 & 17 & e16 \\
\hline 5 & --- & --- & --- & --- & --- & --- & 132 & e90 & e37 & e19 & $\mathrm{e} 18$ & e15 \\
\hline 6 & --- & --- & --- & --- & --- & --- & 385 & 86 & e35 & 17 & 14 & 13 \\
\hline 7 & --- & --- & --- & --- & --- & --- & e573 & e86 & e41 & 17 & $\mathrm{e} 13$ & 13 \\
\hline 8 & --- & --- & --- & --- & --- & --- & 521 & e105 & e42 & e17 & $\mathrm{e} 12$ & 12 \\
\hline 9 & --- & --- & --- & --- & --- & --- & e440 & e110 & e35 & 20 & 12 & 12 \\
\hline 10 & --- & --- & --- & --- & --- & --- & e470 & e100 & e28 & 23 & 11 & 12 \\
\hline 11 & --- & --- & --- & --- & --- & --- & e540 & e88 & e26 & 23 & 11 & 11 \\
\hline 12 & --- & --- & --- & --- & --- & --- & e450 & e90 & e28 & 19 & e11 & e11 \\
\hline 13 & --- & --- & --- & --- & --- & --- & e520 & e90 & e 40 & 14 & $\mathrm{e} 11$ & 11 \\
\hline 14 & --- & --- & --- & --- & --- & --- & 538 & e80 & 48 & 13 & $\mathrm{e} 14$ & 11 \\
\hline 15 & --- & --- & --- & --- & --- & --- & 444 & e75 & 46 & 13 & $\mathrm{e} 15$ & 11 \\
\hline 16 & --- & --- & --- & --- & --- & --- & e540 & e100 & e41 & e14 & 13 & 11 \\
\hline 17 & --- & --- & --- & --- & --- & --- & e550 & e130 & 33 & 15 & 13 & e11 \\
\hline 18 & --- & --- & --- & --- & --- & --- & e500 & e135 & 32 & e14 & 28 & e11 \\
\hline 19 & --- & --- & --- & --- & --- & --- & $\mathrm{e} 450$ & e130 & 29 & 12 & 43 & e11 \\
\hline 20 & --- & --- & --- & --- & --- & --- & e380 & e120 & e32 & e12 & e36 & 10 \\
\hline 21 & --- & --- & --- & --- & --- & --- & e330 & e110 & e32 & 20 & $\mathrm{e} 30$ & 9.9 \\
\hline 22 & --- & --- & --- & --- & --- & --- & e260 & e100 & 32 & 19 & e53 & 9.5 \\
\hline 23 & --- & --- & --- & --- & --- & --- & $\mathrm{e} 210$ & e90 & e28 & e31 & 76 & e12 \\
\hline 24 & --- & --- & --- & --- & --- & --- & $\mathrm{e} 170$ & e80 & 22 & e36 & 59 & e14 \\
\hline 25 & --- & --- & --- & --- & --- & 282 & $\mathrm{e} 145$ & e72 & 26 & 26 & $\mathrm{e} 45$ & e12 \\
\hline 26 & --- & --- & --- & --- & --- & --- & e130 & e75 & 24 & 20 & e39 & e11 \\
\hline 27 & --- & --- & --- & --- & --- & --- & e120 & e76 & 24 & 21 & e33 & e22 \\
\hline 28 & --- & --- & --- & --- & --- & 298 & $\mathrm{e} 125$ & e64 & 23 & e31 & $\mathrm{e} 30$ & 78 \\
\hline 29 & --- & --- & --- & --- & --- & 321 & e130 & e58 & 27 & 32 & 27 & e79 \\
\hline 30 & --- & --- & --- & --- & --- & 298 & e115 & e53 & 32 & e26 & 25 & 54 \\
\hline 31 & --- & --- & --- & --- & --- & 271 & --- & e49 & --- & e21 & $\mathrm{e} 23$ & --- \\
\hline TOTAL & --- & --- & --- & --- & --- & --- & 9923 & 2903 & 1018 & 640 & 787 & 559.4 \\
\hline MEAN & --- & --- & --- & --- & --- & --- & 331 & 93.6 & 33.9 & 20.6 & 25.4 & 18.6 \\
\hline MAX & --- & --- & --- & --- & --- & --- & 573 & 135 & 48 & 36 & 76 & 79 \\
\hline MIN & --- & --- & --- & --- & --- & --- & 115 & 49 & 22 & 12 & 11 & 9.5 \\
\hline CFSM & --- & --- & --- & --- & --- & --- & 7.66 & 2.17 & .79 & .48 & .59 & .43 \\
\hline IN. & --- & --- & --- & --- & --- & --- & 8.54 & 2.50 & .88 & .55 & .68 & .48 \\
\hline
\end{tabular}


Appendix 1. Daily mean streamflow at partial-record sediment stations in the Housatonic River Basin, western Massachusetts, March 1994 through April 1996-Continued

\section{WILLIAMS RIVER, AT RAILROAD BRIDGE, NEAR GREAT BARRINGTON, MA—Continued DISCHARGE, CUBIC FEET PER SECOND, WATER YEAR OCTOBER 1994 TO SEPTEMBER 1995 DAILY MEAN VALUES}

\begin{tabular}{|c|c|c|c|c|c|c|c|c|c|c|c|c|}
\hline DAY & OCT & NOV & DEC & JAN & FEB & MAR & APR & MAY & JUN & JUL & AUG & SEP \\
\hline 1 & e41 & e20 & 52 & e92 & e95 & 62 & e75 & e67 & e31 & e11 & e5.6 & 1.5 \\
\hline 2 & e36 & e23 & 49 & e105 & e90 & e57 & e68 & e64 & 28 & e16 & 5.1 & e1.5 \\
\hline 3 & e31 & 25 & 45 & 101 & e80 & e52 & e64 & e59 & e29 & 18 & 5.0 & e1.5 \\
\hline 4 & 26 & 24 & 43 & e90 & e73 & e50 & 69 & 57 & e35 & e15 & 5.2 & e1.6 \\
\hline 5 & 24 & 23 & 69 & e82 & e66 & e 48 & e70 & 55 & 37 & e13 & e5.8 & 1.6 \\
\hline 6 & 20 & e23 & 129 & e76 & e62 & 58 & e62 & e60 & 32 & 11 & 20 & 1.4 \\
\hline 7 & e19 & e23 & 124 & e92 & e59 & e67 & 62 & $\mathrm{e} 50$ & 28 & 11 & 22 & 1.4 \\
\hline 8 & e19 & e23 & 94 & e105 & e57 & 110 & e60 & e48 & e25 & e11 & 16 & 1.2 \\
\hline 9 & e18 & 22 & 80 & e92 & e54 & e185 & e60 & $\mathrm{e} 45$ & 23 & e9.9 & 13 & e1.4 \\
\hline 10 & $\mathrm{e} 23$ & 23 & 75 & e83 & e52 & 353 & e70 & 46 & e22 & e9.7 & 11 & 1.9 \\
\hline 11 & e26 & 22 & e85 & e76 & 50 & e460 & e66 & 34 & e22 & e9.1 & 9.4 & $\mathrm{e} 2.0$ \\
\hline 12 & e24 & 20 & 107 & e70 & e49 & e329 & 57 & e37 & $\mathrm{e} 23$ & 8.3 & e8.6 & e 2.0 \\
\hline 13 & e21 & 18 & e182 & 86 & e48 & 193 & 96 & 60 & 26 & e8.1 & e7.8 & 2.4 \\
\hline 14 & e20 & e18 & e142 & e100 & e47 & 205 & 112 & e 50 & 25 & 7.6 & 6.9 & e2.4 \\
\hline 15 & e19 & 18 & e108 & e130 & e47 & 204 & e100 & 39 & e22 & 7.4 & e6.5 & $\mathrm{e} 2.2$ \\
\hline 16 & e19 & 19 & e91 & e170 & 50 & 197 & e86 & e39 & e21 & 7.6 & e5.8 & e2.4 \\
\hline 17 & e19 & 19 & e82 & e180 & e50 & e185 & 72 & e39 & e19 & e7.8 & 5.6 & e3.4 \\
\hline 18 & 18 & 20 & e80 & e185 & 50 & e166 & e68 & 38 & e18 & e7.4 & 5.4 & e4.1 \\
\hline 19 & 18 & 21 & 72 & e175 & e48 & e153 & 82 & e37 & e16 & e6.9 & e5.0 & $\mathrm{e} 4.5$ \\
\hline 20 & e19 & 21 & 67 & e155 & e47 & e142 & e104 & 35 & 15 & 6.7 & e4.7 & 4.3 \\
\hline 21 & $\mathrm{e} 22$ & e22 & 66 & 193 & 46 & 137 & e82 & e33 & 14 & 6.5 & 3.8 & 4.1 \\
\hline 22 & 21 & 34 & 60 & e230 & 43 & e153 & 89 & e30 & e14 & e6.5 & 3.4 & 4.1 \\
\hline 23 & e20 & e39 & e59 & e250 & e41 & 137 & 79 & e28 & e14 & e6.5 & 3.3 & 8.6 \\
\hline 24 & e23 & e35 & e75 & e200 & 55 & 122 & e74 & e25 & e13 & 6.5 & 2.6 & 8.8 \\
\hline 25 & 22 & e29 & 122 & e175 & e72 & e108 & $\mathrm{e} 70$ & 23 & e12 & e6.0 & 2.6 & 6.9 \\
\hline 26 & 21 & e27 & e134 & e155 & e64 & e98 & 67 & e27 & e13 & 5.4 & e2.6 & e6.9 \\
\hline 27 & e19 & e25 & e125 & e140 & e54 & 93 & 65 & e31 & 15 & e5.8 & e2.3 & e6.9 \\
\hline 28 & 19 & 34 & 102 & e120 & 59 & e84 & 71 & e32 & e14 & e5.6 & $\mathrm{e} 2.2$ & 6.0 \\
\hline 29 & 18 & 45 & e88 & e110 & --- & e78 & e75 & 32 & e12 & e5.8 & e1.9 & e5.8 \\
\hline 30 & 19 & 59 & e80 & e105 & --- & 78 & 70 & 36 & e11 & 6.5 & e1.6 & e5.6 \\
\hline 31 & e19 & --- & e75 & 100 & --- & 84 & --- & e35 & --- & e5.8 & e1.6 & --- \\
\hline TOTAL & 683 & 774 & 2762 & 4023 & 1608 & 4448 & 2245 & 1291 & 629 & 269.4 & 202.3 & 108.4 \\
\hline MEAN & 22.0 & 25.8 & 89.1 & 130 & 57.4 & 143 & 74.8 & 41.6 & 21.0 & 8.69 & 6.53 & 3.61 \\
\hline MAX & 41 & 59 & 182 & 250 & 95 & 460 & 112 & 67 & 37 & 18 & 22 & 8.8 \\
\hline MIN & 18 & 18 & 43 & 70 & 41 & 48 & 57 & 23 & 11 & 5.4 & 1.6 & 1.2 \\
\hline CFSM & .51 & .60 & 2.06 & 3.00 & 1.33 & 3.32 & 1.73 & .96 & .49 & .20 & .15 & .08 \\
\hline IN. & .59 & .67 & 2.38 & 3.46 & 1.38 & 3.83 & 1.93 & 1.11 & .54 & .23 & .17 & .09 \\
\hline
\end{tabular}


Appendix 1. Daily mean streamflow at partial-record sediment stations in the Housatonic River Basin, western Massachusetts, March 1994 through April 1996-Continued

01197802 WILLIAMS RIVER, AT RAILROAD BRIDGE, NEAR GREAT BARRINGTON, MA—Continued DISCHARGE, CUBIC FEET PER SECOND, WATER YEAR OCTOBER 1995 TO SEPTEMBER 1996 DAILY MEAN VALUES

\begin{tabular}{|c|c|c|c|c|c|c|c|c|c|c|c|c|}
\hline DAY & OCT & NOV & DEC & JAN & FEB & MAR & APR & MAY & JUN & JUL & AUG & SEP \\
\hline 1 & e3.8 & e67 & e66 & e34 & e180 & e135 & 90 & --- & --- & --- & --- & --- \\
\hline 2 & 3.6 & 73 & e64 & e34 & e155 & e120 & 104 & --- & --- & --- & --- & --- \\
\hline 3 & e3.4 & e94 & e60 & e34 & e135 & e110 & --- & --- & --- & --- & --- & --- \\
\hline 4 & e 4.3 & e78 & e64 & e33 & e115 & e95 & --- & --- & --- & --- & --- & --- \\
\hline 5 & 4.1 & e64 & 63 & e32 & e100 & e86 & --- & --- & --- & --- & --- & --- \\
\hline 6 & 53 & e56 & e63 & e32 & e94 & e86 & --- & --- & --- & --- & --- & --- \\
\hline 7 & e59 & 54 & 59 & e32 & e86 & e88 & --- & --- & --- & --- & --- & --- \\
\hline 8 & 38 & 66 & 54 & e32 & e81 & e84 & --- & --- & --- & --- & --- & --- \\
\hline 9 & e27 & e71 & e50 & e33 & e78 & e76 & --- & --- & --- & --- & --- & --- \\
\hline 10 & e19 & e62 & 49 & e33 & e75 & e70 & --- & --- & --- & --- & --- & --- \\
\hline 11 & 12 & 55 & 49 & e33 & e72 & e65 & --- & --- & --- & --- & --- & --- \\
\hline 12 & 10 & 155 & e48 & e33 & e69 & e62 & --- & --- & --- & --- & --- & --- \\
\hline 13 & 8.8 & 303 & e48 & e33 & e54 & e66 & --- & --- & --- & --- & --- & --- \\
\hline 14 & e8.8 & 225 & 52 & e34 & e50 & e68 & --- & --- & --- & --- & --- & --- \\
\hline 15 & 16 & 197 & e50 & e33 & e48 & e74 & --- & --- & --- & --- & --- & --- \\
\hline 16 & e20 & e229 & 46 & e32 & e45 & e95 & --- & --- & --- & --- & --- & --- \\
\hline 17 & e16 & e187 & e45 & e32 & e43 & e117 & --- & --- & --- & --- & --- & --- \\
\hline 18 & e14 & 157 & e44 & e36 & e42 & e105 & --- & --- & --- & --- & --- & --- \\
\hline 19 & e13 & e151 & e43 & e40 & e36 & e97 & --- & --- & --- & --- & --- & --- \\
\hline 20 & 13 & 149 & e43 & 630 & e36 & 121 & --- & --- & --- & --- & --- & --- \\
\hline 21 & 19 & e139 & e42 & 610 & 102 & e125 & --- & --- & --- & --- & --- & --- \\
\hline 22 & 120 & e125 & e41 & 366 & 244 & e110 & --- & --- & --- & --- & --- & --- \\
\hline 23 & 106 & e113 & e40 & 269 & 269 & e95 & --- & --- & --- & --- & --- & --- \\
\hline 24 & e78 & e101 & e39 & 288 & 251 & e85 & --- & --- & --- & --- & --- & --- \\
\hline 25 & e56 & e91 & e39 & 506 & $\mathrm{e} 246$ & e81 & --- & --- & --- & --- & --- & --- \\
\hline 26 & 44 & e85 & e38 & 456 & 200 & 113 & --- & --- & --- & --- & --- & --- \\
\hline 27 & e41 & 79 & e37 & e519 & 174 & e125 & --- & --- & --- & --- & --- & --- \\
\hline 28 & 80 & e74 & e36 & 758 & e180 & e113 & --- & --- & --- & --- & --- & --- \\
\hline 29 & 141 & e71 & 35 & 453 & e168 & 102 & --- & --- & --- & --- & --- & --- \\
\hline 30 & e105 & 66 & e34 & e322 & --- & e98 & --- & --- & --- & --- & --- & --- \\
\hline 31 & e81 & --- & e34 & e234 & --- & e91 & --- & --- & --- & --- & --- & --- \\
\hline TOTAL & 1217.8 & 3437 & 1475 & 6046 & 3428 & 2958 & --- & --- & --- & --- & --- & --- \\
\hline MEAN & 39.3 & 115 & 47.6 & 195 & 118 & 95.4 & --- & --- & --- & --- & --- & --- \\
\hline MAX & 141 & 303 & 66 & 758 & 269 & 135 & --- & --- & --- & --- & --- & --- \\
\hline MIN & 3.4 & 54 & 34 & 32 & 36 & 62 & --- & --- & --- & --- & --- & --- \\
\hline CFSM & .91 & 2.65 & 1.10 & 4.51 & 2.74 & 2.21 & --- & --- & --- & --- & --- & --- \\
\hline IN. & 1.05 & 2.96 & 1.27 & 5.21 & 2.95 & 2.55 & --- & --- & --- & --- & --- & --- \\
\hline
\end{tabular}


Appendix 1. Daily mean streamflow at partial-record sediment stations in the Housatonic River Basin, western Massachusetts, March 1994 through April 1996-Continued

01198122 IRONWORKS BROOK, EAST ROAD, AT SHEFFIELD, MA

DISCHARGE, CUBIC FEET PER SECOND, WATER YEAR OCTOBER 1993 TO SEPTEMBER 1994 DAILY MEAN VALUES

\begin{tabular}{|c|c|c|c|c|c|c|c|c|c|c|c|c|}
\hline DAY & OCT & NOV & DEC & JAN & FEB & MAR & APR & MAY & JUN & JUL & AUG & SEP \\
\hline 1 & --- & --- & --- & --- & --- & --- & e73 & e18 & e4.1 & $\mathrm{e} 4.4$ & e10 & 3.9 \\
\hline 2 & --- & --- & --- & --- & --- & --- & e74 & e16 & 3.6 & e1.9 & e8.2 & 2.9 \\
\hline 3 & --- & --- & --- & --- & --- & --- & e70 & e14 & e 3.1 & $\mathrm{e} 1.5$ & 8.2 & 2.0 \\
\hline 4 & --- & --- & --- & --- & --- & --- & e100 & 12 & e3.0 & $\mathrm{e} 1.3$ & 11 & 1.5 \\
\hline 5 & --- & --- & --- & --- & --- & --- & 81 & e12 & $\mathrm{e} 2.3$ & e1.1 & 8.7 & 1.3 \\
\hline 6 & --- & --- & --- & --- & --- & --- & 75 & 13 & $\mathrm{e} 2.5$ & e.89 & 7.2 & 2.7 \\
\hline 7 & --- & --- & --- & --- & --- & --- & 106 & e13 & e11 & .79 & $\mathrm{e} 4.8$ & 3.6 \\
\hline 8 & --- & --- & --- & --- & --- & --- & 70 & e23 & e7.8 & e.79 & 3.3 & 3.2 \\
\hline 9 & --- & --- & --- & --- & --- & --- & e55 & e18 & e5.6 & e.75 & 2.6 & 2.9 \\
\hline 10 & --- & --- & --- & --- & --- & --- & e62 & e14 & 4.6 & e.75 & 2.2 & 2.2 \\
\hline 11 & --- & --- & --- & --- & --- & --- & e80 & e11 & e4.5 & e.70 & 1.7 & 1.7 \\
\hline 12 & --- & --- & --- & --- & --- & --- & e66 & e15 & e7.9 & e.70 & e1.5 & 3.9 \\
\hline 13 & --- & --- & --- & --- & --- & --- & e70 & 18 & e7.7 & .60 & $\mathrm{e} 2.2$ & 5.3 \\
\hline 14 & --- & --- & --- & --- & --- & --- & 93 & e14 & e6.8 & .73 & e5.1 & 5.3 \\
\hline 15 & --- & --- & --- & --- & --- & --- & 69 & e10 & 6.0 & .73 & 4.2 & 5.1 \\
\hline 16 & --- & --- & --- & --- & --- & --- & e67 & e23 & e5.6 & e.75 & 2.6 & 4.6 \\
\hline 17 & --- & --- & --- & --- & --- & --- & e68 & e20 & e 4.9 & e.79 & 2.0 & 4.2 \\
\hline 18 & --- & --- & --- & --- & --- & --- & e52 & e17 & e4.1 & $\mathrm{e} 1.3$ & 15 & 5.3 \\
\hline 19 & --- & --- & --- & --- & --- & --- & e46 & 17 & e3.1 & $\mathrm{e} 1.3$ & 15 & 4.6 \\
\hline 20 & --- & --- & --- & --- & --- & --- & e44 & e14 & $\mathrm{e} 2.3$ & e1.1 & 11 & 3.9 \\
\hline 21 & --- & --- & --- & --- & --- & --- & e38 & e13 & e1.6 & .86 & 9.2 & 3.6 \\
\hline 22 & --- & --- & --- & --- & --- & --- & e28 & e10 & 1.3 & 1.7 & 27 & 3.2 \\
\hline 23 & --- & --- & --- & --- & --- & --- & e26 & e8.8 & e1.1 & e85 & 22 & 5.4 \\
\hline 24 & --- & --- & --- & --- & --- & --- & e24 & e7.5 & e1.1 & $\mathrm{e} 40$ & 14 & 4.9 \\
\hline 25 & --- & --- & --- & --- & --- & 99 & e21 & e7.0 & e1.3 & e17 & 11 & 4.2 \\
\hline 26 & --- & --- & --- & --- & --- & --- & e20 & e7.5 & $\mathrm{e} 1.3$ & e14 & 8.2 & 3.6 \\
\hline 27 & --- & --- & --- & --- & --- & --- & e20 & e8.0 & e1.1 & 28 & 6.2 & 6.2 \\
\hline 28 & --- & --- & --- & --- & --- & 124 & e19 & 6.5 & e. 98 & e42 & 4.9 & 15 \\
\hline 29 & --- & --- & --- & --- & --- & 105 & e18 & e6.0 & 1.7 & e28 & 8.2 & 8.4 \\
\hline 30 & --- & --- & --- & --- & --- & 80 & e17 & e5.1 & e3.3 & e17 & 4.9 & 6.7 \\
\hline 31 & --- & --- & --- & --- & --- & 72 & --- & e4.7 & --- & e14 & 4.2 & --- \\
\hline TOTAL & --- & --- & --- & --- & --- & --- & --- & --- & --- & --- & 246.3 & 131.3 \\
\hline MEAN & --- & --- & --- & --- & --- & --- & --- & --- & --- & --- & 7.95 & 4.38 \\
\hline MAX & --- & --- & --- & --- & --- & --- & --- & --- & --- & --- & 27 & 15 \\
\hline MIN & --- & --- & --- & --- & --- & --- & --- & --- & --- & --- & 1.5 & 1.3 \\
\hline CFSM & --- & --- & --- & --- & --- & --- & --- & --- & --- & --- & .71 & .39 \\
\hline IN. & --- & --- & --- & --- & --- & --- & --- & --- & --- & --- & .82 & .44 \\
\hline
\end{tabular}


Appendix 1. Daily mean streamflow at partial-record sediment stations in the Housatonic River Basin, western Massachusetts, March 1994 through April 1996-Continued

01198122 IRONWORKS BROOK, EAST ROAD, AT SHEFFIELD, MA-Continued DISCHARGE, CUBIC FEET PER SECOND, WATER YEAR OCTOBER 1994 TO SEPTEMBER 1995 DAILY MEAN VALUES

\begin{tabular}{|c|c|c|c|c|c|c|c|c|c|c|c|c|}
\hline DAY & OCT & NOV & DEC & JAN & FEB & MAR & APR & MAY & JUN & JUL & AUG & SEP \\
\hline 1 & 6.7 & 4.8 & 13 & e34 & 19 & 23 & 14 & 11 & 4.9 & 0.56 & 0.39 & 0.04 \\
\hline 2 & 7.2 & 6.2 & 12 & e31 & 16 & 19 & 11 & 10 & 4.2 & 1.2 & .45 & .05 \\
\hline 3 & 6.2 & 5.8 & 11 & $\mathrm{e} 24$ & e15 & 16 & 11 & 9.6 & 4.2 & .87 & .63 & .05 \\
\hline 4 & 5.8 & 5.3 & 10 & $\mathrm{e} 21$ & e15 & 15 & 12 & 9.0 & 7.6 & .56 & .62 & .10 \\
\hline 5 & e5.4 & 4.9 & 28 & e18 & e14 & 13 & 14 & 8.3 & e5.9 & .49 & 1.2 & 1.2 \\
\hline 6 & 4.2 & 4.6 & 33 & e17 & e14 & e16 & 11 & 10 & 5.5 & .43 & 6.6 & 1.0 \\
\hline 7 & 3.9 & 4.9 & 23 & e33 & e13 & 21 & 10 & 10 & 5.3 & .56 & 2.6 & .73 \\
\hline 8 & e3.6 & 4.6 & 22 & e29 & e13 & 170 & 10 & e8.5 & 4.9 & .56 & 2.6 & .70 \\
\hline 9 & 3.4 & 4.2 & e21 & $\mathrm{e} 22$ & e12 & 164 & 12 & e7.3 & 4.2 & .56 & 1.1 & .62 \\
\hline 10 & 6.9 & e5.1 & e20 & e18 & e12 & 69 & 16 & 6.9 & 3.9 & .25 & .87 & .62 \\
\hline 11 & 7.4 & 4.9 & e33 & e16 & e12 & 42 & $\mathrm{e} 12$ & 8.3 & 3.7 & .49 & .82 & .49 \\
\hline 12 & 5.6 & 4.2 & $\mathrm{e} 27$ & e17 & e12 & 33 & 11 & e8.5 & 4.4 & .49 & .78 & .29 \\
\hline 13 & 4.2 & 3.9 & $\mathrm{e} 22$ & 26 & e11 & 39 & 38 & e7.3 & 4.4 & .29 & .78 & .39 \\
\hline 14 & 3.9 & 3.9 & e21 & 36 & e11 & 39 & 22 & e7.1 & 3.5 & .32 & .62 & .29 \\
\hline 15 & 4.4 & 3.9 & e19 & 47 & e11 & 37 & 18 & e7.1 & 3.5 & .29 & .49 & .49 \\
\hline 16 & 3.6 & 3.6 & 18 & 48 & e11 & 31 & 16 & e6.8 & 3.2 & .16 & .39 & .29 \\
\hline 17 & 3.6 & 3.9 & 15 & 44 & e11 & 37 & 15 & e5.9 & 2.2 & .16 & .29 & .49 \\
\hline 18 & 3.3 & 3.6 & 17 & 41 & 12 & 27 & 13 & e6.6 & 1.7 & .87 & .18 & 1.2 \\
\hline 19 & 2.7 & 3.9 & 16 & 33 & 13 & 24 & e19 & e6.8 & 1.7 & .62 & e. 12 & .70 \\
\hline 20 & 3.1 & 3.3 & e14 & 48 & 13 & e20 & e19 & 7.6 & 2.0 & .38 & .07 & .44 \\
\hline 21 & 4.9 & 4.2 & 14 & 72 & 13 & $\mathrm{e} 22$ & e16 & 6.6 & 1.5 & e. 29 & .05 & .34 \\
\hline 22 & 4.2 & 12 & 12 & 56 & 12 & 22 & 18 & 6.1 & 1.1 & e. 29 & .04 & .70 \\
\hline 23 & 4.8 & 7.7 & 11 & 47 & 12 & 21 & 15 & 5.3 & .87 & e. 29 & .03 & e3.3 \\
\hline 24 & 6.7 & e6.2 & e66 & 38 & 19 & 20 & 15 & 4.9 & .87 & .34 & .03 & e1.4 \\
\hline 25 & 5.8 & 5.8 & e56 & 33 & 16 & 18 & 12 & 9.9 & .87 & .49 & .03 & e1.2 \\
\hline 26 & 4.9 & 4.8 & e32 & e29 & e13 & 16 & 11 & 7.3 & .78 & 1.1 & .02 & 1.7 \\
\hline 27 & 4.6 & 5.8 & $\mathrm{e} 27$ & e26 & e11 & 15 & 11 & 6.9 & 1.1 & 1.9 & e.02 & 1.7 \\
\hline 28 & e 4.1 & 23 & e23 & $\mathrm{e} 24$ & 23 & 13 & 12 & 5.3 & .78 & .97 & .04 & 1.3 \\
\hline 29 & 4.1 & 22 & e21 & e22 & --- & 13 & 11 & 6.1 & .62 & 1.3 & .03 & .97 \\
\hline 30 & e3.9 & 14 & e19 & e 21 & --- & 13 & 11 & 7.1 & .56 & .97 & .04 & .87 \\
\hline 31 & 3.9 & --- & e17 & $\mathrm{e} 20$ & --- & 13 & --- & 5.7 & --- & .62 & .03 & --- \\
\hline TOTAL & 147.0 & 195.0 & 693 & 991 & 379 & 1041 & 436 & 233.8 & 89.95 & 18.67 & 21.96 & 23.66 \\
\hline MEAN & 4.74 & 6.50 & 22.4 & 32.0 & 13.5 & 33.6 & 14.5 & 7.54 & 3.00 & .60 & .71 & .79 \\
\hline MAX & 7.4 & 23 & 66 & 72 & 23 & 170 & 38 & 11 & 7.6 & 1.9 & 6.6 & 3.3 \\
\hline MIN & 2.7 & 3.3 & 10 & 16 & 11 & 13 & 10 & 4.9 & .56 & .16 & .02 & .04 \\
\hline CFSM & .42 & .58 & 2.00 & 2.85 & 1.21 & 3.00 & 1.30 & .67 & .27 & .05 & .06 & .07 \\
\hline IN. & .49 & .65 & 2.30 & 3.29 & 1.26 & 3.46 & 1.45 & .78 & .30 & .06 & .07 & .08 \\
\hline
\end{tabular}


Appendix 1. Daily mean streamflow at partial-record sediment stations in the Housatonic River Basin, western Massachusetts, March 1994 through April 1996-Continued

01198122 IRONWORKS BROOK, EAST ROAD, AT SHEFFIELD, MA-Continued DISCHARGE, CUBIC FEET PER SECOND, WATER YEAR OCTOBER 1995 TO SEPTEMBER 1996 DAILY MEAN VALUES

\begin{tabular}{|c|c|c|c|c|c|c|c|c|c|c|c|c|}
\hline DAY & OCT & NOV & DEC & JAN & FEB & MAR & APR & MAY & JUN & JUL & AUG & SEP \\
\hline 1 & 0.56 & 19 & 13 & e6.8 & e38 & 29 & 18 & --- & --- & --- & --- & --- \\
\hline 2 & .44 & e26 & 12 & e6.7 & e32 & 29 & 35 & --- & --- & --- & --- & --- \\
\hline 3 & e. 34 & e28 & 11 & e6.5 & e27 & 26 & --- & --- & --- & --- & --- & --- \\
\hline 4 & e. 44 & e23 & 12 & e6.4 & e24 & 24 & --- & --- & --- & --- & --- & --- \\
\hline 5 & 3.5 & e18 & e12 & e6.2 & e21 & 22 & --- & --- & --- & --- & --- & --- \\
\hline 6 & 22 & 16 & e12 & e6.1 & e19 & e22 & --- & --- & --- & --- & --- & --- \\
\hline 7 & 11 & 15 & 11 & e6.1 & e18 & e21 & --- & --- & --- & --- & --- & --- \\
\hline 8 & e7.1 & 21 & 11 & e6.0 & e17 & e19 & --- & --- & --- & --- & --- & --- \\
\hline 9 & e5.9 & 16 & 11 & e6.0 & e16 & 18 & --- & --- & --- & --- & --- & --- \\
\hline 10 & 5.5 & 14 & e11 & e6.0 & e15 & e16 & --- & --- & --- & --- & --- & --- \\
\hline 11 & 4.6 & 13 & e10 & e6.0 & e15 & 15 & --- & --- & --- & --- & --- & --- \\
\hline 12 & 4.1 & 84 & e10 & e6.0 & e14 & 16 & --- & --- & --- & --- & --- & --- \\
\hline 13 & 3.6 & e38 & e9.6 & e6.0 & e13 & 18 & --- & --- & --- & --- & --- & --- \\
\hline 14 & 3.5 & e33 & e9.4 & e6.0 & e11 & 26 & --- & --- & --- & --- & --- & --- \\
\hline 15 & e12 & 67 & e9.7 & e6.0 & e10 & 50 & --- & --- & --- & --- & --- & --- \\
\hline 16 & 7.1 & e47 & e9.8 & e5.9 & e9.6 & 51 & --- & --- & --- & --- & --- & --- \\
\hline 17 & 5.5 & 31 & e9.6 & e5.8 & e9.2 & 28 & --- & --- & --- & --- & --- & --- \\
\hline 18 & e4.6 & 24 & e9.4 & e8.5 & e8.8 & 29 & --- & --- & --- & --- & --- & --- \\
\hline 19 & e4.2 & 26 & e9.1 & 150 & e8.4 & e32 & --- & --- & --- & --- & --- & --- \\
\hline 20 & 3.7 & 24 & e8.8 & 138 & e10 & 46 & --- & --- & --- & --- & --- & --- \\
\hline 21 & 12 & 21 & e8.6 & 80 & 65 & 41 & --- & --- & --- & --- & --- & --- \\
\hline 22 & 30 & 19 & e8.4 & e41 & 100 & 36 & --- & --- & --- & --- & --- & --- \\
\hline 23 & 14 & 17 & e8.3 & e27 & 70 & 32 & --- & --- & --- & --- & --- & --- \\
\hline 24 & 12 & 16 & e8.2 & 107 & 76 & 27 & --- & --- & --- & --- & --- & --- \\
\hline 25 & e11 & 16 & e7.9 & 118 & 68 & 26 & --- & --- & --- & --- & --- & --- \\
\hline 26 & 9.9 & e16 & e7.7 & e46 & 51 & 29 & --- & --- & --- & --- & --- & --- \\
\hline 27 & 8.8 & e16 & e7.4 & 157 & e41 & e28 & --- & --- & --- & --- & --- & --- \\
\hline 28 & 131 & e16 & e7.2 & 171 & $\mathrm{e} 42$ & e26 & --- & --- & --- & --- & --- & --- \\
\hline 29 & 48 & 16 & e7.0 & 85 & 38 & 24 & --- & --- & --- & --- & --- & --- \\
\hline 30 & 29 & 13 & e7.0 & 64 & --- & 18 & --- & --- & --- & --- & --- & --- \\
\hline 31 & 23 & --- & e6.9 & e47 & --- & 18 & --- & --- & --- & --- & --- & --- \\
\hline TOTAL & 438.38 & 749 & 296.0 & 1344.0 & 887.0 & 842 & --- & --- & --- & --- & --- & --- \\
\hline MEAN & 14.1 & 25.0 & 9.55 & 43.4 & 30.6 & 27.2 & --- & --- & --- & --- & --- & --- \\
\hline MAX & 131 & 84 & 13 & 171 & 100 & 51 & --- & --- & --- & --- & --- & --- \\
\hline MIN & .34 & 13 & 6.9 & 5.8 & 8.4 & 15 & --- & --- & --- & --- & --- & --- \\
\hline CFSM & 1.26 & 2.23 & .85 & 3.87 & 2.73 & 2.43 & --- & --- & --- & --- & --- & --- \\
\hline IN. & 1.46 & 2.49 & .98 & 4.46 & 2.95 & 2.80 & --- & --- & --- & --- & --- & --- \\
\hline
\end{tabular}


Appendix 1. Daily mean streamflow at partial-record sediment stations in the Housatonic River Basin, western Massachusetts, March 1994 through April 1996-Continued

01198200 KONKAPOT RIVER AT ASHLEY FALLS, MA

DISCHARGE, CUBIC FEET PER SECOND, WATER YEAR OCTOBER 1993 TO SEPTEMBER 1994 DAILY MEAN VALUES

\begin{tabular}{|c|c|c|c|c|c|c|c|c|c|c|c|c|}
\hline DAY & OCT & NOV & DEC & JAN & FEB & MAR & APR & MAY & JUN & JUL & AUG & SEP \\
\hline 1 & --- & --- & --- & --- & --- & --- & e270 & e125 & 54 & 61 & 104 & 52 \\
\hline 2 & --- & --- & --- & --- & --- & --- & e280 & e125 & 55 & 46 & 79 & 38 \\
\hline 3 & --- & --- & --- & --- & --- & --- & e280 & e115 & 51 & 46 & 91 & 36 \\
\hline 4 & --- & --- & --- & --- & --- & --- & $\mathrm{e} 460$ & 109 & 47 & 35 & 79 & 34 \\
\hline 5 & --- & --- & --- & --- & --- & --- & 378 & 100 & 46 & 29 & 71 & 33 \\
\hline 6 & --- & --- & --- & --- & --- & --- & 461 & 97 & 45 & 29 & 70 & 30 \\
\hline 7 & --- & --- & --- & --- & --- & --- & 588 & e99 & 89 & 27 & 57 & 29 \\
\hline 8 & --- & --- & --- & --- & --- & --- & 480 & e150 & 97 & 27 & 52 & 28 \\
\hline 9 & --- & --- & --- & --- & --- & --- & e380 & e140 & 60 & 30 & 43 & 29 \\
\hline 10 & --- & --- & --- & --- & --- & --- & $\mathrm{e} 400$ & e120 & 50 & 27 & 39 & 29 \\
\hline 11 & --- & --- & --- & --- & --- & --- & e530 & e110 & 53 & 25 & 36 & 27 \\
\hline 12 & --- & --- & --- & --- & --- & --- & e430 & e125 & 51 & 24 & 35 & 24 \\
\hline 13 & --- & --- & --- & --- & --- & --- & e470 & 133 & 51 & 24 & e37 & 29 \\
\hline 14 & --- & --- & --- & --- & --- & --- & 725 & e115 & 50 & 70 & e55 & 29 \\
\hline 15 & --- & --- & --- & --- & --- & --- & 396 & e105 & 69 & 36 & e55 & 30 \\
\hline 16 & --- & --- & --- & --- & --- & --- & e400 & e145 & 64 & 34 & e42 & 28 \\
\hline 17 & --- & --- & --- & --- & --- & --- & e410 & e155 & 54 & 34 & 37 & 29 \\
\hline 18 & --- & --- & --- & --- & --- & --- & e350 & e140 & 47 & 30 & 94 & 41 \\
\hline 19 & --- & --- & --- & --- & --- & --- & e320 & 132 & 44 & 29 & 110 & 37 \\
\hline 20 & --- & --- & --- & --- & --- & --- & e300 & e125 & 43 & 29 & 79 & 31 \\
\hline 21 & --- & --- & --- & --- & --- & --- & e270 & e115 & $\mathrm{e} 42$ & 35 & 74 & 30 \\
\hline 22 & --- & --- & --- & --- & --- & --- & e200 & e100 & 40 & 31 & 247 & 28 \\
\hline 23 & --- & --- & --- & --- & --- & --- & e190 & e95 & 38 & 475 & 200 & 53 \\
\hline 24 & --- & --- & --- & --- & --- & --- & e170 & e89 & 36 & 357 & 96 & 69 \\
\hline 25 & --- & --- & --- & --- & --- & 357 & e150 & e88 & 35 & 150 & 80 & 57 \\
\hline 26 & --- & --- & --- & --- & --- & --- & e145 & e95 & 34 & 105 & 70 & 42 \\
\hline 27 & --- & --- & --- & --- & --- & --- & e140 & e91 & 32 & 245 & 61 & 47 \\
\hline 28 & --- & --- & --- & --- & --- & 489 & e135 & 83 & 35 & 277 & 65 & 79 \\
\hline 29 & --- & --- & --- & --- & --- & 410 & e130 & e74 & 34 & 227 & 60 & 58 \\
\hline 30 & --- & --- & --- & --- & --- & 310 & e120 & e70 & 50 & 128 & 50 & 50 \\
\hline 31 & --- & --- & --- & --- & --- & 244 & --- & e64 & --- & 121 & 43 & --- \\
\hline TOTAL & --- & --- & --- & --- & --- & --- & --- & --- & 1496 & 2843 & 2311 & 1156 \\
\hline MEAN & --- & --- & --- & --- & --- & --- & --- & --- & 49.9 & 91.7 & 74.5 & 38.5 \\
\hline MAX & --- & --- & --- & --- & --- & --- & -- & --- & 97 & 475 & 247 & 79 \\
\hline MIN & --- & --- & --- & --- & --- & --- & --- & --- & 32 & 24 & 35 & 24 \\
\hline CFSM & --- & --- & --- & --- & --- & --- & --- & --- & .82 & 1.50 & 1.22 & .63 \\
\hline IN. & --- & --- & --- & --- & --- & --- & --- & --- & .91 & 1.73 & 1.41 & .70 \\
\hline
\end{tabular}


Appendix 1. Daily mean streamflow at partial-record sediment stations in the Housatonic River Basin, western Massachusetts, March 1994 through April 1996-Continued

01198200 KONKAPOT RIVER AT ASHLEY FALLS, MA-Continued

DISCHARGE, CUBIC FEET PER SECOND, WATER YEAR OCTOBER 1994 TO SEPTEMBER 1995 DAILY MEAN VALUES

\begin{tabular}{|c|c|c|c|c|c|c|c|c|c|c|c|c|}
\hline DAY & OCT & NOV & DEC & JAN & FEB & MAR & APR & MAY & JUN & JUL & AUG & SEP \\
\hline 1 & 51 & e28 & 97 & 208 & 99 & 168 & 89 & 72 & 65 & 17 & 16 & 9.1 \\
\hline 2 & 54 & 37 & 74 & 193 & e94 & 106 & e88 & 65 & 61 & 24 & 17 & 11 \\
\hline 3 & 64 & 37 & 67 & 139 & e91 & 89 & 83 & 63 & 54 & 34 & 17 & 12 \\
\hline 4 & 115 & 35 & 59 & 111 & e92 & 84 & 87 & 57 & 72 & 26 & 16 & 11 \\
\hline 5 & 124 & 34 & 126 & 105 & e87 & 79 & 89 & 57 & 80 & 23 & 18 & 10 \\
\hline 6 & 109 & 31 & 288 & 97 & e86 & 89 & 72 & 55 & 60 & 21 & 79 & 10 \\
\hline 7 & 87 & 29 & 135 & 224 & e83 & 110 & 75 & 51 & 48 & 22 & 50 & 9.1 \\
\hline 8 & 79 & 30 & 118 & 181 & e82 & 284 & 74 & e 52 & 44 & 27 & 37 & 9.1 \\
\hline 9 & 75 & 29 & 91 & 123 & e80 & 676 & 73 & 52 & 40 & 27 & 29 & 12 \\
\hline 10 & 74 & 30 & 88 & 97 & e78 & 259 & 73 & 52 & 37 & 22 & 25 & 11 \\
\hline 11 & 65 & 33 & e145 & 88 & e76 & 194 & e68 & 55 & 38 & 27 & 18 & 9.3 \\
\hline 12 & 59 & 31 & 129 & 90 & e74 & 166 & 79 & 65 & 40 & 33 & 17 & 9.8 \\
\hline 13 & 48 & 31 & 104 & 131 & e72 & 177 & 249 & 56 & 38 & 31 & 18 & 12 \\
\hline 14 & 43 & 29 & 92 & e194 & 70 & 208 & 149 & 53 & 37 & 27 & 16 & 12 \\
\hline 15 & 34 & 31 & 83 & 227 & 73 & 201 & 83 & 57 & 36 & 24 & 16 & 11 \\
\hline 16 & 29 & 29 & 80 & 214 & 78 & 197 & 34 & 61 & 35 & 24 & 13 & 12 \\
\hline 17 & 28 & 29 & 75 & 253 & 78 & 208 & 14 & 51 & 35 & 23 & 14 & 16 \\
\hline 18 & 26 & 29 & 86 & 180 & 78 & 149 & 78 & 55 & 30 & 24 & 13 & 18 \\
\hline 19 & 28 & 31 & 86 & 140 & 78 & 129 & 131 & 55 & 24 & 22 & e12 & 16 \\
\hline 20 & 33 & 29 & 73 & 192 & 80 & 124 & 143 & 59 & 24 & 22 & e12 & 14 \\
\hline 21 & 37 & 32 & 67 & 410 & 83 & 129 & 123 & 51 & 22 & 18 & 12 & 13 \\
\hline 22 & 38 & 68 & 67 & 291 & 77 & 157 & 112 & 49 & 21 & 17 & 16 & 17 \\
\hline 23 & 46 & 51 & e66 & 194 & 72 & 134 & 88 & 43 & 19 & 17 & 14 & 43 \\
\hline 24 & 46 & e44 & 394 & 165 & 105 & 127 & 87 & 48 & 19 & 17 & 12 & 29 \\
\hline 25 & 43 & e39 & e508 & 148 & 97 & 123 & 82 & 77 & 19 & 18 & 11 & 21 \\
\hline 26 & 41 & e37 & 202 & 118 & 75 & 104 & 68 & 67 & 19 & 22 & 11 & 21 \\
\hline 27 & 34 & e37 & 138 & 119 & 78 & 98 & 65 & 60 & 19 & 29 & 11 & 22 \\
\hline 28 & 31 & 90 & 123 & e106 & 135 & 94 & 68 & 56 & 17 & 27 & 8.7 & 20 \\
\hline 29 & 30 & 208 & 120 & e104 & --- & 90 & 72 & 53 & 17 & 24 & 8.3 & 17 \\
\hline 30 & 25 & 143 & e98 & e102 & --- & 89 & 65 & 105 & 17 & 20 & 8.3 & 17 \\
\hline 31 & e26 & --- & 98 & 101 & --- & 99 & --- & 78 & --- & 17 & e8.7 & --- \\
\hline TOTAL & 1622 & 1371 & 3977 & 5045 & 2351 & 4941 & 2661 & 1830 & 1087 & 726 & 574.0 & 454.4 \\
\hline MEAN & 52.3 & 45.7 & 128 & 163 & 84.0 & 159 & 88.7 & 59.0 & 36.2 & 23.4 & 18.5 & 15.1 \\
\hline MAX & 124 & 208 & 508 & 410 & 135 & 676 & 249 & 105 & 80 & 34 & 79 & 43 \\
\hline MIN & 25 & 28 & 59 & 88 & 70 & 79 & 14 & 43 & 17 & 17 & 8.3 & 9.1 \\
\hline CFSM & .86 & .75 & 2.10 & 2.66 & 1.37 & 2.61 & 1.45 & .97 & .59 & .38 & .30 & .25 \\
\hline IN. & .99 & .83 & 2.42 & 3.07 & 1.43 & 3.01 & 1.62 & 1.11 & .66 & .44 & .35 & .28 \\
\hline
\end{tabular}


Appendix 1. Daily mean streamflow at partial-record sediment stations in the Housatonic River Basin, western Massachusetts, March 1994 through April 1996-Continued

01198200 KONKAPOT RIVER AT ASHLEY FALLS, MA-Continued

DISCHARGE, CUBIC FEET PER SECOND, WATER YEAR OCTOBER 1995 TO SEPTEMBER 1996 DAILY MEAN VALUES

\begin{tabular}{|c|c|c|c|c|c|c|c|c|c|c|c|c|}
\hline DAY & OCT & NOV & DEC & JAN & FEB & MAR & APR & MAY & JUN & JUL & AUG & SEP \\
\hline 1 & 16 & 172 & 99 & e67 & 194 & 157 & 116 & 544 & 61 & 48 & 72 & 31 \\
\hline 2 & 16 & 204 & 108 & e67 & 184 & e150 & 226 & 334 & 61 & 46 & 161 & 32 \\
\hline 3 & 16 & 241 & 93 & e67 & e174 & e139 & 204 & 246 & 78 & 49 & 104 & 30 \\
\hline 4 & 15 & 196 & 110 & e66 & e163 & e135 & 141 & 249 & 135 & e228 & e85 & 30 \\
\hline 5 & 21 & e174 & 104 & e65 & 149 & 128 & 133 & 237 & 133 & 82 & 82 & 28 \\
\hline 6 & 148 & 146 & 115 & e64 & 149 & e142 & 131 & 237 & 108 & 72 & 84 & e27 \\
\hline 7 & 89 & 140 & 106 & e64 & 149 & e135 & 164 & 207 & 95 & 52 & 82 & e29 \\
\hline 8 & 49 & 217 & 85 & e63 & 149 & e131 & 144 & 184 & 96 & 49 & 82 & 30 \\
\hline 9 & 36 & 149 & e82 & e62 & e141 & e129 & 135 & 169 & 215 & 86 & 63 & 32 \\
\hline 10 & 31 & 125 & e82 & e62 & 132 & e129 & 146 & 160 & 132 & 64 & 69 & 35 \\
\hline 11 & 27 & 581 & e82 & e61 & e131 & 128 & 139 & 217 & 99 & 45 & 59 & 32 \\
\hline 12 & 25 & 748 & 81 & e61 & 123 & e128 & 133 & 448 & 86 & 40 & 52 & 28 \\
\hline 13 & 23 & 415 & 88 & e61 & e108 & 133 & 224 & 337 & 76 & 264 & 51 & 30 \\
\hline 14 & 36 & e316 & e78 & e60 & e100 & e155 & 462 & 210 & 69 & 770 & 51 & 29 \\
\hline 15 & 106 & 497 & 100 & e60 & e95 & 184 & 366 & 232 & 62 & 403 & 50 & 30 \\
\hline 16 & 71 & 300 & e90 & e60 & e92 & e222 & 427 & 269 & 58 & 750 & 48 & 31 \\
\hline 17 & 53 & 226 & 81 & 60 & e89 & e179 & 665 & 244 & 49 & 502 & 61 & 31 \\
\hline 18 & e53 & 213 & 78 & 79 & e87 & 169 & 392 & 178 & 47 & 324 & 52 & 294 \\
\hline 19 & 55 & 204 & 76 & 363 & 86 & 165 & 317 & 183 & 42 & 260 & 47 & 276 \\
\hline 20 & 55 & 187 & e74 & 1220 & e97 & 256 & 244 & 163 & 41 & 213 & 42 & 109 \\
\hline 21 & 152 & 174 & e74 & 573 & 219 & e263 & 217 & 155 & 57 & 163 & 40 & 186 \\
\hline 22 & 581 & 164 & e73 & 305 & 463 & 222 & 191 & 167 & 59 & 124 & 36 & 474 \\
\hline 23 & 196 & 151 & 71 & 227 & 447 & 176 & 241 & 135 & 53 & 111 & 40 & 356 \\
\hline 24 & 124 & 142 & e71 & 338 & 371 & 167 & 352 & 133 & 61 & 110 & 72 & 266 \\
\hline 25 & 110 & 125 & e71 & 824 & 313 & 147 & 252 & 129 & 54 & 108 & 58 & 156 \\
\hline 26 & 97 & 124 & 69 & 380 & 241 & 137 & 198 & 128 & 52 & 144 & 49 & 98 \\
\hline 27 & 96 & 123 & 69 & 542 & 232 & 166 & 229 & 108 & 46 & 123 & 43 & 81 \\
\hline 28 & 680 & 111 & 70 & 988 & 229 & 152 & 195 & 100 & 43 & 109 & 41 & 69 \\
\hline 29 & 811 & 106 & 65 & 419 & 195 & 137 & 236 & 91 & 45 & 93 & 40 & 128 \\
\hline 30 & 264 & 101 & 62 & 306 & --- & 133 & 468 & 74 & 44 & 85 & e38 & 121 \\
\hline 31 & 230 & --- & 66 & 228 & --- & 120 & --- & e66 & --- & e82 & e33 & --- \\
\hline TOTAL & 4282 & 6772 & 2573 & 7862 & 5302 & 4914 & 7488 & 6334 & 2257 & 5599 & 1887 & 3129 \\
\hline MEAN & 138 & 226 & 83.0 & 254 & 183 & 159 & 250 & 204 & 75.2 & 181 & 60.9 & 104 \\
\hline MAX & 811 & 748 & 115 & 1220 & 463 & 263 & 665 & 544 & 215 & 770 & 161 & 474 \\
\hline MIN & 15 & 101 & 62 & 60 & 86 & 120 & 116 & 66 & 41 & 40 & 33 & 27 \\
\hline CFSM & 2.26 & 3.69 & 1.36 & 4.15 & 2.99 & 2.59 & 4.09 & 3.34 & 1.23 & 2.96 & 1.00 & 1.71 \\
\hline IN. & 2.61 & 4.12 & 1.57 & 4.79 & 3.23 & 2.99 & 4.56 & 3.86 & 1.37 & 3.41 & 1.15 & 1.91 \\
\hline
\end{tabular}


Appendix 2. Instantaneous suspended-sediment and associated data at three continuous-record and four partial-record sediment stations in the Housatonic River Basin, western Massachusetts, March 1994 through April 1996

[Source of data except for stations 01197500, 01198000, and 01198125, Socolow and others, 1996, 1997. Locations shown in fig. 5 and described in table 2. Five-digit numbers in parentheses at bottom of column headers are U.S. Geological Survey water-quality parameter codes. SED., sediment; SUSP., suspended; US/CM, microsiemen per centimeter at 25 degrees Celsius; DEG C, degrees Celsius; MG/L, milligram per liter; T/DAY, ton per day; MM, millimeter; ,-- no data]

\begin{tabular}{|c|c|c|c|c|c|c|c|c|}
\hline DATE & TIME & $\begin{array}{c}\text { DISCHARGE, } \\
\text { INST. CUBIC } \\
\text { FEET PER } \\
\text { SECOND } \\
(00061)\end{array}$ & $\begin{array}{c}\text { SPECIFIC } \\
\text { CONDUC- } \\
\text { TANCE LAB } \\
(\text { US/CM) } \\
(90095)\end{array}$ & $\begin{array}{c}\text { TEMPERA- } \\
\text { TURE AIR } \\
\text { (DEG C) } \\
(00020)\end{array}$ & $\begin{array}{l}\text { TEMPERA- } \\
\text { TURE WATER } \\
\text { (DEG C) } \\
(00010)\end{array}$ & $\begin{array}{c}\text { SEDIMENT, } \\
\text { SUSPENDED } \\
(M G / L) \\
(80154)\end{array}$ & $\begin{array}{c}\text { SEDIMENT, } \\
\text { DISCHARGE, } \\
\text { SUSPENDED } \\
\text { (T/DAY) } \\
(80155)\end{array}$ & $\begin{array}{l}\text { SED. SUSP. } \\
\text { SIEVE DIAM. } \\
\text { \% FINER THAN } \\
.062 \text { MM } \\
(70331)\end{array}$ \\
\hline
\end{tabular}

01197500 - HOUSATONIC RIVER NEAR GREAT BARRINGTON, MA

WATER-QUALITY DATA, WATER YEAR OCTOBER 1993 TO SEPTEMBER 1994

\begin{tabular}{|c|c|c|c|c|c|c|c|c|}
\hline \multicolumn{9}{|l|}{ MAR } \\
\hline $28 \ldots$ & 1500 & 1610 & -- & 6.0 & 2.5 & 8 & 35 & -- \\
\hline $28 \ldots$ & 1510 & 1620 & -- & 6.0 & 2.5 & 9 & 39 & -- \\
\hline $28 \ldots$ & 1525 & 1620 & -- & 6.0 & 2.5 & 10 & 44 & -- \\
\hline $29 \ldots$ & 1740 & 1770 & -- & 3.0 & 2.0 & 14 & 67 & -- \\
\hline $30 \ldots$ & 1425 & 1620 & -- & 3.0 & 2.5 & 5 & 22 & -- \\
\hline $31 \ldots$ & 1635 & 1360 & 244 & 8.0 & 3.5 & 2 & 7.3 & -- \\
\hline \multicolumn{9}{|l|}{ APR } \\
\hline $05 \ldots$ & 1835 & 2340 & 181 & 16.0 & 5.5 & 9 & 57 & -- \\
\hline $05 \ldots$ & 1840 & 2340 & 184 & 16.0 & 5.5 & 9 & 57 & -- \\
\hline $06 \ldots$ & 1300 & 2390 & -- & 12.0 & 4.5 & 21 & 136 & 62 \\
\hline $07 \ldots$ & 1010 & 2800 & -- & -- & 4.0 & 26 & 197 & 70 \\
\hline $07 \ldots$ & 1555 & 2980 & -- & -- & 4.0 & 41 & 330 & 70 \\
\hline $07 \ldots$ & 1600 & 2980 & 171 & -- & 5.5 & 54 & 434 & -- \\
\hline $08 \ldots$ & 1105 & 3280 & -- & -- & 4.0 & 41 & 363 & 67 \\
\hline $08 \ldots$ & 1110 & 3280 & 155 & -- & 4.0 & 24 & 213 & -- \\
\hline $08 \ldots$ & 1515 & 3280 & -- & -- & 5.0 & 26 & 230 & 80 \\
\hline $14 \ldots$ & 1050 & 3560 & 154 & 15.0 & 5.5 & 28 & 269 & -- \\
\hline $14 \ldots$ & 1100 & 3560 & -- & 15.0 & 5.5 & 35 & 336 & -- \\
\hline $14 \ldots$ & 1625 & 3560 & 148 & 21.0 & 6.0 & 30 & 288 & -- \\
\hline $14 \ldots$ & 1630 & 3560 & -- & 21.0 & 6.0 & 39 & 375 & 75 \\
\hline $14 \ldots$ & 1955 & 3560 & -- & 15.0 & 6.5 & 39 & 375 & 73 \\
\hline $15 \ldots$ & 0740 & 3940 & 137 & 8.0 & 6.0 & 28 & 298 & -- \\
\hline $15 \ldots$ & 1040 & 3940 & 136 & 23.0 & 6.0 & 23 & 245 & -- \\
\hline \multicolumn{9}{|l|}{ MAY } \\
\hline $06 \ldots$ & 1610 & 524 & 290 & 10.5 & 13.0 & 4 & 5.7 & -- \\
\hline $06 \ldots$ & 1615 & 524 & 293 & 10.5 & 13.0 & 7 & 9.9 & -- \\
\hline $13 \ldots$ & 1700 & 703 & 290 & 12.5 & 13.0 & 6 & 11 & -- \\
\hline $13 \ldots$ & 1705 & 703 & 281 & 12.5 & 13.0 & 6 & 11 & -- \\
\hline $19 \ldots$ & 1550 & 998 & 233 & 13.5 & 12.0 & 6 & 16 & -- \\
\hline $19 \ldots$ & 1555 & 998 & 235 & 13.5 & 12.0 & 2 & 5.4 & -- \\
\hline $28 \ldots$ & 1035 & 457 & 300 & 14.0 & 14.5 & 8 & 9.9 & -- \\
\hline $28 \ldots$ & 1040 & 457 & 337 & 14.0 & 14.5 & 9 & 11 & 42 \\
\hline \multicolumn{9}{|l|}{ JUN } \\
\hline $02 \ldots$ & 1050 & 281 & 331 & 17.0 & 17.0 & 10 & 7.6 & -- \\
\hline $02 \ldots$ & 1055 & 281 & 334 & 17.0 & 17.0 & 9 & 6.8 & -- \\
\hline $10 \ldots$ & 0925 & 195 & 374 & 17.0 & 19.0 & 5 & 2.6 & -- \\
\hline $10 \ldots$ & 0930 & 195 & 367 & 17.0 & 19.0 & 8 & 4.2 & -- \\
\hline $15 \ldots$ & 1435 & 260 & 387 & 30.5 & 25.0 & 3 & 2.1 & -- \\
\hline $15 \ldots$ & 1445 & 260 & 380 & 30.5 & 25.0 & 6 & 4.2 & -- \\
\hline $22 \ldots$ & 0940 & 156 & 375 & 20.5 & 22.0 & 14 & 5.9 & -- \\
\hline $22 \ldots$ & 0945 & 156 & 255 & 20.5 & 22.0 & 12 & 5.1 & 94 \\
\hline $29 \ldots$ & 0940 & 138 & 400 & 24.0 & 22.5 & 8 & 3.0 & -- \\
\hline $29 \ldots$ & 0945 & 138 & 410 & 24.0 & 22.5 & 5 & 1.9 & -- \\
\hline
\end{tabular}


Appendix 2. Instantaneous suspended-sediment and associated data at three continuous-record and four partial-record sediment stations in the Housatonic River Basin, western Massachusetts, March 1994 through April 1996-Continued

\begin{tabular}{|c|c|c|c|c|c|c|c|c|}
\hline DATE & TIME & $\begin{array}{c}\text { DISCHARGE, } \\
\text { INST. CUBIC } \\
\text { FEET PER } \\
\text { SECOND } \\
(00061)\end{array}$ & $\begin{array}{c}\text { SPECIFIC } \\
\text { CONDUC- } \\
\text { TANCE LAB } \\
\text { (US/CM) } \\
(90095)\end{array}$ & $\begin{array}{c}\text { TEMPERA- } \\
\text { TURE AIR } \\
\text { (DEG C) } \\
\text { (00020) }\end{array}$ & $\begin{array}{l}\text { TEMPERA- } \\
\text { TURE WATER } \\
\text { (DEG C) } \\
(00010)\end{array}$ & $\begin{array}{c}\text { SEDIMENT, } \\
\text { SUSPENDED } \\
\text { (MG/L) } \\
(\mathbf{8 0 1 5 4 )}\end{array}$ & $\begin{array}{c}\text { SEDIMENT, } \\
\text { DISCHARGE, } \\
\text { SUSPENDED } \\
(\text { T/DAY) } \\
(\mathbf{8 0 1 5 5 )}\end{array}$ & $\begin{array}{l}\text { SED. SUSP. } \\
\text { SIEVE DIAM. } \\
\text { \% FINER THAN } \\
.062 \text { MM } \\
(\mathbf{7 0 3 3 1})\end{array}$ \\
\hline
\end{tabular}

01197500 - HOUSATONIC RIVER NEAR GREAT BARRINGTON, MA-Continued WATER-QUALITY DATA, WATER YEAR OCTOBER 1993 TO SEPTEMBER 1994—Continued

\begin{tabular}{|c|c|c|c|c|c|c|c|c|}
\hline \multicolumn{9}{|l|}{ JUL } \\
\hline $07 \ldots$ & 0750 & 113 & 359 & 25.0 & 24.5 & 3 & 0.92 & -- \\
\hline $07 \ldots$ & 0755 & 113 & 352 & 25.0 & 24.5 & 3 & .92 & -- \\
\hline $15 \ldots$ & 1520 & 204 & 432 & 24.0 & 23.0 & 5 & 2.8 & -- \\
\hline $15 \ldots$ & 1525 & 204 & 408 & 24.0 & 23.0 & 5 & 2.8 & -- \\
\hline $21 \ldots$ & 1515 & 210 & 470 & 32.5 & 27.0 & 7 & 4.0 & -- \\
\hline $21 \ldots$ & 1520 & 210 & 496 & 32.5 & 27.0 & 7 & 4.0 & -- \\
\hline $27 \ldots$ & 1200 & 285 & 288 & 26.0 & 24.5 & 11 & 8.5 & -- \\
\hline $27 \ldots$ & 1205 & 285 & 278 & 26.0 & 24.5 & 8 & 6.2 & -- \\
\hline \multicolumn{9}{|l|}{ AUG } \\
\hline $04 \ldots$ & 1015 & 144 & 339 & 27.0 & 24.0 & 5 & 1.9 & -- \\
\hline $04 \ldots$ & 1025 & 144 & 342 & 27.0 & 24.0 & 5 & 1.9 & -- \\
\hline $04 \ldots$ & 1100 & 144 & 340 & 27.0 & 24.0 & 6 & 2.3 & -- \\
\hline $11 \ldots$ & 1715 & 97 & 402 & 24.0 & 22.0 & 7 & 1.8 & -- \\
\hline $11 \ldots$ & 1720 & 97 & 396 & 24.0 & 22.0 & 6 & 1.6 & -- \\
\hline $17 \ldots$ & 1405 & 132 & 417 & 22.5 & 20.0 & 11 & 3.9 & -- \\
\hline $17 \ldots$ & 1425 & 132 & 449 & 22.5 & 20.0 & 9 & 3.2 & -- \\
\hline $17 \ldots$ & 1455 & 132 & 453 & 22.5 & 20.0 & 14 & 5.0 & -- \\
\hline $19 \ldots$ & 0655 & 403 & 373 & 19.0 & 19.5 & 12 & 13 & 30 \\
\hline $19 \ldots$ & 0700 & 403 & 376 & 19.0 & 19.5 & 21 & 23 & -- \\
\hline $23 \ldots$ & 1115 & 854 & 237 & 18.5 & 18.0 & 8 & 18 & 46 \\
\hline $23 \ldots$ & 1120 & 854 & 251 & 18.5 & 18.0 & 16 & 37 & -- \\
\hline $24 \ldots$ & 0755 & 564 & 247 & 9.0 & 17.5 & 14 & 21 & -- \\
\hline \multicolumn{9}{|l|}{ SEP } \\
\hline $01 \ldots$ & 1715 & 150 & 349 & 18.0 & 19.5 & 5 & 2.0 & -- \\
\hline $01 \ldots$ & 1720 & 150 & 346 & 18.0 & 19.5 & 10 & 4.0 & -- \\
\hline $06 \ldots$ & 1810 & 110 & 383 & 18.5 & 18.0 & 3 & .89 & -- \\
\hline $06 \ldots$ & 1815 & 110 & 395 & 18.5 & 18.0 & 5 & 1.5 & -- \\
\hline $15 \ldots$ & 1025 & 113 & 446 & 15.5 & 18.0 & 5 & 1.5 & -- \\
\hline $15 \ldots$ & 1027 & 113 & 439 & 15.5 & 18.0 & 1 & .31 & -- \\
\hline $21 \ldots$ & 1155 & 97 & 473 & -- & 18.0 & 5 & 1.3 & -- \\
\hline $21 \ldots$ & 1200 & 97 & 479 & -- & 18.0 & 6 & 1.6 & -- \\
\hline $28 \ldots$ & 1020 & 632 & 365 & 17.0 & 17.0 & 8 & 14 & 72 \\
\hline $28 \ldots$ & 1410 & 690 & 357 & 18.5 & 17.5 & 16 & 30 & -- \\
\hline $30 \ldots$ & 1635 & 440 & 264 & 14.0 & 15.0 & 8 & 9.5 & -- \\
\hline $30 \ldots$ & 1640 & 440 & 265 & 14.0 & 15.0 & 10 & 12 & -- \\
\hline \multicolumn{9}{|c|}{ WATER-QUALITY DATA, WATER YEAR OCTOBER 1994 TO SEPTEMBER 1995} \\
\hline \multicolumn{9}{|l|}{ OCT } \\
\hline $04 \ldots$ & 1440 & 244 & 335 & 11.0 & 11.5 & 2 & 1.3 & -- \\
\hline $09 \ldots$ & 1107 & 244 & 343 & 18.5 & 12.5 & 3 & 2.0 & -- \\
\hline $13 \ldots$ & 1145 & 213 & 333 & 11.5 & 10.5 & 1 & .58 & -- \\
\hline $19 \ldots$ & 1205 & 199 & 374 & 15.0 & 11.0 & 1 & .54 & -- \\
\hline $21 \ldots$ & 1135 & 252 & 397 & 12.5 & 12.5 & 4 & 2.7 & -- \\
\hline \multicolumn{9}{|l|}{ NOV } \\
\hline $01 \ldots$ & 1230 & 213 & 355 & 17.5 & 10.5 & 1 & .58 & -- \\
\hline $02 \ldots$ & 0835 & 236 & 349 & 5.5 & 10.5 & 2 & 1.3 & -- \\
\hline $03 \ldots$ & 0905 & 272 & 366 & 10.0 & 9.5 & 1 & .73 & -- \\
\hline $08 \ldots$ & 1530 & 192 & 368 & 12.5 & 9.5 & 1 & .52 & -- \\
\hline
\end{tabular}


Appendix 2. Instantaneous suspended-sediment and associated data at three continuous-record and four partial-record sediment stations in the Housatonic River Basin, western Massachusetts, March 1994 through April 1996-Continued

\begin{tabular}{|c|c|c|c|c|c|c|c|c|}
\hline DATE & TIME & $\begin{array}{c}\text { DISCHARGE, } \\
\text { INST. CUBIC } \\
\text { FEET PER } \\
\text { SECOND } \\
(00061)\end{array}$ & $\begin{array}{c}\text { SPECIFIC } \\
\text { CONDUC- } \\
\text { TANCE LAB } \\
\text { (US/CM) } \\
(90095)\end{array}$ & $\begin{array}{c}\text { TEMPERA- } \\
\text { TURE AIR } \\
\text { (DEG C) } \\
(00020)\end{array}$ & $\begin{array}{l}\text { TEMPERA- } \\
\text { TURE WATER } \\
\text { (DEG C) } \\
(00010)\end{array}$ & $\begin{array}{l}\text { SEDIMENT, } \\
\text { SUSPENDED } \\
\text { (MG/L) } \\
(\mathbf{8 0 1 5 4 )}\end{array}$ & $\begin{array}{c}\text { SEDIMENT, } \\
\text { DISCHARGE, } \\
\text { SUSPENDED } \\
\text { (T/DAY) } \\
(80155)\end{array}$ & $\begin{array}{l}\text { SED. SUSP. } \\
\text { SIEVE DIAM. } \\
\text { \% FINER THAN } \\
.062 \mathrm{MM} \\
(70331)\end{array}$ \\
\hline
\end{tabular}

01197500 - HOUSATONIC RIVER NEAR GREAT BARRINGTON, MA-Continued WATER-QUALITY DATA, WATER YEAR OCTOBER 1994 TO SEPTEMBER 1995—Continued

\begin{tabular}{|c|c|c|c|c|c|c|c|c|}
\hline \multicolumn{9}{|c|}{ NOV_-Continued } \\
\hline $08 \ldots$ & 1535 & 192 & 365 & 12.5 & 9.5 & 1 & 0.52 & -- \\
\hline $15 \ldots$ & 1335 & 172 & 387 & 12.5 & 8.0 & 1 & .46 & -- \\
\hline $18 \ldots$ & 1105 & 185 & 364 & 11.0 & 7.5 & 1 & .50 & -- \\
\hline $21 \ldots$ & 1010 & 182 & 397 & 6.5 & 6.5 & 1 & .49 & -- \\
\hline $26 \ldots$ & 1225 & 236 & 310 & 3.5 & 2.0 & 1 & .64 & -- \\
\hline $28 \ldots$ & 1805 & 388 & 315 & -- & 3.5 & 2 & 2.1 & -- \\
\hline $29 \ldots$ & 0935 & 690 & 347 & -- & 3.0 & 4 & 7.5 & -- \\
\hline $29 \ldots$ & 1630 & 716 & 276 & 2.5 & 2.5 & 10 & 19 & -- \\
\hline $29 \ldots$ & 1650 & 716 & 285 & 2.5 & 2.5 & 10 & 19 & 89 \\
\hline $30 \ldots$ & 1415 & 625 & 299 & 5.0 & 2.5 & 1 & 1.7 & -- \\
\hline \multicolumn{9}{|l|}{ DEC } \\
\hline $05 \ldots$ & 1605 & 502 & 287 & 8.5 & 4.5 & ${ }^{1} 0$ & .54 & -- \\
\hline $06 \ldots$ & 1035 & 1100 & 253 & 10.5 & 5.5 & 11 & 33 & -- \\
\hline $06 \ldots$ & 1525 & 1170 & 240 & -- & 5.5 & 6 & 19 & 32 \\
\hline $06 \ldots$ & 1534 & 1170 & 240 & -- & 5.5 & 14 & 44 & 57 \\
\hline $06 \ldots$ & 1618 & 1170 & 233 & -- & 5.5 & 2 & 6.3 & -- \\
\hline $07 \ldots$ & 1215 & 1050 & 197 & 3.0 & 5.5 & 3 & 8.5 & -- \\
\hline $11 \ldots$ & 1005 & 632 & 255 & 2.0 & 2.0 & 2 & 3.4 & -- \\
\hline $11 \ldots$ & 1545 & 683 & 259 & 1.5 & 2.0 & 2 & 3.7 & -- \\
\hline $15 \ldots$ & 1340 & 440 & 297 & 4.0 & 1.0 & 2 & 2.4 & -- \\
\hline $18 \ldots$ & 1255 & 446 & 291 & 3.5 & 2.0 & 4 & 4.8 & -- \\
\hline $21 \ldots$ & 1050 & 424 & 307 & 1.5 & 1.5 & 2 & 2.3 & -- \\
\hline $24 \ldots$ & 0910 & 468 & 298 & -- & 3.5 & 3 & 3.8 & -- \\
\hline $24 \ldots$ & 1630 & 976 & 290 & 7.0 & 3.5 & 8 & 21 & 59 \\
\hline $28 \ldots$ & 1515 & 651 & 214 & 7.0 & 2.0 & 3 & 5.3 & -- \\
\hline \multicolumn{9}{|l|}{ JAN } \\
\hline $01 \ldots$ & 1550 & 737 & 268 & 4.0 & .5 & 3 & 6.0 & -- \\
\hline $02 \ldots$ & 1045 & 939 & 252 & -.5 & 1.0 & 7 & 18 & 61 \\
\hline $09 \ldots$ & 1515 & 664 & 326 & 1.0 & .5 & 3 & 5.4 & -- \\
\hline $14 \ldots$ & 1020 & 690 & 282 & 4.0 & 2.0 & 4 & 7.5 & -- \\
\hline $15 \ldots$ & 1205 & 1040 & 339 & 14.0 & 4.5 & 9 & 25 & -- \\
\hline $16 \ldots$ & 1435 & 1320 & 218 & 12.5 & 5.5 & 13 & 46 & 81 \\
\hline $21 \ldots$ & 0955 & 1360 & 228 & 2.5 & 4.0 & 13 & 48 & 81 \\
\hline $23 \ldots$ & 1100 & 1500 & 197 & -1.0 & 2.0 & 5 & 20 & 47 \\
\hline $26 \ldots$ & 1120 & 765 & 248 & -2.0 & 1.0 & 7 & 14 & -- \\
\hline $31 \ldots$ & 1535 & 513 & 270 & 2.0 & .5 & 2 & 2.8 & -- \\
\hline \multicolumn{9}{|l|}{ FEB } \\
\hline $09 \ldots$ & 1550 & 260 & 323 & -3.5 & .0 & 1 & .70 & -- \\
\hline $14 \ldots$ & 1530 & 285 & 345 & -3.5 & .0 & ${ }^{1} 0$ & .31 & -- \\
\hline $18 \ldots$ & 1145 & 321 & 340 & 5.0 & .5 & 3 & 2.6 & -- \\
\hline $21 \ldots$ & 1235 & 281 & 370 & 2.5 & 1.0 & 1 & .76 & -- \\
\hline $24 \ldots$ & 1125 & 368 & 357 & 1.5 & 2.5 & 2 & 2.0 & -- \\
\hline $28 \ldots$ & 1145 & 330 & 371 & 1.0 & .5 & 1 & .89 & -- \\
\hline \multicolumn{9}{|l|}{ MAR } \\
\hline $01 \ldots$ & 1535 & 613 & 340 & 2.0 & 1.5 & 6 & 9.9 & 76 \\
\hline $06 \ldots$ & 1145 & 373 & 340 & 4.5 & 2.5 & 2 & 2.0 & -- \\
\hline $08 \ldots$ & 1630 & 868 & 338 & 4.0 & 5.0 & 5 & 12 & 84 \\
\hline $09 \ldots$ & 1600 & 2730 & 181 & -6.0 & 1.0 & 35 & 258 & 86 \\
\hline $10 \ldots$ & 1620 & 2450 & 166 & -2.0 & .5 & 18 & 119 & -- \\
\hline
\end{tabular}


Appendix 2. Instantaneous suspended-sediment and associated data at three continuous-record and four partial-record sediment stations in the Housatonic River Basin, western Massachusetts, March 1994 through April 1996-Continued

\begin{tabular}{|c|c|c|c|c|c|c|c|c|}
\hline DATE & TIME & $\begin{array}{c}\text { DISCHARGE, } \\
\text { INST. CUBIC } \\
\text { FEET PER } \\
\text { SECOND } \\
(00061)\end{array}$ & $\begin{array}{c}\text { SPECIFIC } \\
\text { CONDUC- } \\
\text { TANCE LAB } \\
\text { (US/CM) } \\
(90095)\end{array}$ & $\begin{array}{c}\text { TEMPERA- } \\
\text { TURE AIR } \\
\text { (DEG C) } \\
(00020)\end{array}$ & $\begin{array}{l}\text { TEMPERA- } \\
\text { TURE WATER } \\
\text { (DEG C) } \\
(00010)\end{array}$ & $\begin{array}{c}\text { SEDIMENT, } \\
\text { SUSPENDED } \\
\text { (MG/L) } \\
(\mathbf{8 0 1 5 4 )}\end{array}$ & $\begin{array}{c}\text { SEDIMENT, } \\
\text { DISCHARGE, } \\
\text { SUSPENDED } \\
\text { (T/DAY) } \\
(80155)\end{array}$ & $\begin{array}{l}\text { SED. SUSP. } \\
\text { SIEVE DIAM. } \\
\text { \% FINER THAN } \\
.062 \mathrm{MM} \\
(70331)\end{array}$ \\
\hline
\end{tabular}

01197500 - HOUSATONIC RIVER NEAR GREAT BARRINGTON, MA-Continued WATER-QUALITY DATA, WATER YEAR OCTOBER 1994 TO SEPTEMBER 1995—Continued

\begin{tabular}{|c|c|c|c|c|c|c|c|}
\hline \multicolumn{8}{|c|}{ MAR-Continued } \\
\hline $13 \ldots$ & 1200 & 991 & 237 & 12.5 & 3.5 & 4 & 11 \\
\hline $16 \ldots$ & 1640 & 1300 & 207 & 13.5 & 6.0 & 6 & 21 \\
\hline $21 \ldots$ & 1240 & 847 & 217 & 9.5 & 6.5 & 3 & 6.9 \\
\hline $27 \ldots$ & 1545 & 535 & 270 & 10.5 & 8.0 & 4 & 5.8 \\
\hline $31 \ldots$ & 1220 & 462 & 293 & 7.5 & 7.5 & 4 & 5.0 \\
\hline \multicolumn{8}{|l|}{ APR } \\
\hline $03 \ldots$ & 1350 & 363 & 304 & 9.5 & 7.0 & 2 & 2.0 \\
\hline $07 \ldots$ & 1215 & 344 & 317 & 6.5 & 3.5 & 3 & 2.8 \\
\hline $12 \ldots$ & 1325 & 344 & 302 & 7.0 & 6.5 & 4 & 3.7 \\
\hline $13 \ldots$ & 1700 & 737 & 307 & -- & 8.5 & 8 & 16 \\
\hline $14 \ldots$ & 0810 & 820 & 276 & 5.5 & 7.5 & 6 & 13 \\
\hline $14 \ldots$ & 1320 & 800 & 273 & 9.0 & 8.0 & 5 & 11 \\
\hline $15 \ldots$ & 1900 & 594 & 225 & 4.0 & 7.5 & 4 & 6.4 \\
\hline $17 \ldots$ & 1410 & 414 & 260 & 13.0 & 8.0 & 2 & 2.2 \\
\hline $19 \ldots$ & 1020 & 457 & 278 & 9.5 & 9.5 & 2 & 2.5 \\
\hline $22 \ldots$ & 0920 & 607 & 263 & 13.0 & 10.5 & 8 & 13 \\
\hline $23 \ldots$ & 1350 & 541 & 268 & 8.5 & 11.5 & 5 & 7.3 \\
\hline $26 \ldots$ & 1425 & 294 & 276 & 14.0 & 12.0 & 5 & 4.0 \\
\hline $30 \ldots$ & 1235 & 368 & 302 & 13.5 & 13.0 & 5 & 5.0 \\
\hline \multicolumn{8}{|l|}{ MAY } \\
\hline $04 \ldots$ & 1220 & 312 & 323 & 19.5 & 12.0 & 7 & 5.9 \\
\hline $10 \ldots$ & 1245 & 256 & 329 & 10.0 & 13.0 & 7 & 4.8 \\
\hline $13 \ldots$ & 1300 & 339 & 346 & 18.0 & 13.5 & 5 & 4.6 \\
\hline $15 \ldots$ & 1315 & 272 & 336 & 12.0 & 14.0 & 6 & 4.4 \\
\hline $18 \ldots$ & 1240 & 272 & 334 & 15.0 & 15.0 & 8 & 5.9 \\
\hline $25 \ldots$ & 0940 & 252 & 324 & 16.5 & 18.0 & 8 & 5.4 \\
\hline $26 \ldots$ & 1210 & 252 & 365 & 14.5 & 17.5 & 10 & 6.8 \\
\hline $29 \ldots$ & 1300 & 188 & 357 & 17.5 & 17.0 & 8 & 4.1 \\
\hline $30 \ldots$ & 1100 & 277 & 357 & 17.5 & 17.0 & 11 & 8.2 \\
\hline \multicolumn{8}{|l|}{ JUN } \\
\hline $02 \ldots$ & 1345 & 168 & 352 & 22.0 & 19.5 & 5 & 2.3 \\
\hline $05 \ldots$ & 1315 & 507 & 311 & 25.5 & 21.0 & 10 & 14 \\
\hline $06 \ldots$ & 0925 & 419 & 320 & 19.0 & 19.5 & 9 & 10 \\
\hline $13 \ldots$ & 1930 & 210 & 365 & 17.5 & 19.5 & 5 & 2.8 \\
\hline $14 \ldots$ & 0945 & 182 & 371 & 17.5 & 18.0 & 7 & 3.4 \\
\hline $20 \ldots$ & 0900 & 124 & 375 & 26.5 & 23.5 & 6 & 2.0 \\
\hline $20 \ldots$ & 0905 & 124 & 374 & 26.5 & 23.5 & 5 & 1.7 \\
\hline $27 \ldots$ & 0940 & 126 & 395 & 22.0 & 23.0 & 8 & 2.7 \\
\hline \multicolumn{8}{|l|}{ JUL } \\
\hline $03 \ldots$ & 1115 & 153 & 426 & 20.0 & 21.5 & 13 & 5.4 \\
\hline $08 \ldots$ & 1315 & 102 & 424 & 27.0 & 24.0 & 11 & 3.0 \\
\hline $12 \ldots$ & 1210 & 221 & 419 & 24.0 & 22.5 & 12 & 7.2 \\
\hline $14 \ldots$ & 1140 & 129 & 377 & 29.5 & 24.5 & 6 & 2.1 \\
\hline $16 \ldots$ & 1550 & 118 & 436 & 27.0 & 25.5 & 4 & 1.3 \\
\hline $21 \ldots$ & 1315 & 88 & 431 & 26.0 & 24.5 & 5 & 1.2 \\
\hline $24 \ldots$ & 1210 & 93 & 436 & 25.5 & 26.0 & 5 & 1.3 \\
\hline $26 \ldots$ & 1042 & 132 & 426 & 26.0 & 26.5 & 6 & 2.1 \\
\hline $30 \ldots$ & 1150 & 132 & 369 & 26.0 & 26.5 & 7 & 2.5 \\
\hline
\end{tabular}


Appendix 2. Instantaneous suspended-sediment and associated data at three continuous-record and four partial-record sediment stations in the Housatonic River Basin, western Massachusetts, March 1994 through April 1996-Continued

\begin{tabular}{|c|c|c|c|c|c|c|c|c|}
\hline DATE & TIME & $\begin{array}{c}\text { DISCHARGE, } \\
\text { INST. CUBIC } \\
\text { FEET PER } \\
\text { SECOND } \\
(00061)\end{array}$ & $\begin{array}{c}\text { SPECIFIC } \\
\text { CONDUC- } \\
\text { TANCE LAB } \\
\text { (US/CM) } \\
(90095)\end{array}$ & $\begin{array}{c}\text { TEMPERA- } \\
\text { TURE AIR } \\
\text { (DEG C) } \\
\text { (00020) }\end{array}$ & $\begin{array}{l}\text { TEMPERA- } \\
\text { TURE WATER } \\
\text { (DEG C) } \\
(00010)\end{array}$ & $\begin{array}{c}\text { SEDIMENT, } \\
\text { SUSPENDED } \\
(M G / L) \\
(80154)\end{array}$ & $\begin{array}{c}\text { SEDIMENT, } \\
\text { DISCHARGE, } \\
\text { SUSPENDED } \\
\text { (T/DAY) } \\
(\mathbf{8 0 1 5 5 )}\end{array}$ & $\begin{array}{l}\text { SED. SUSP. } \\
\text { SIEVE DIAM. } \\
\text { \% FINER THAN } \\
.062 \text { MM } \\
(70331)\end{array}$ \\
\hline \multicolumn{9}{|c|}{$\begin{array}{l}\text { 01197500 - HOUSATONIC RIVER NEAR GREAT BARRINGTON, MA-Continued } \\
\text { WATER-QUALITY DATA, WATER YEAR OCTOBER } 1994 \text { TO SEPTEMBER 1995-Continued }\end{array}$} \\
\hline \multicolumn{9}{|l|}{ AUG } \\
\hline $04 \ldots$ & 1020 & 81 & 383 & 28.0 & 25.5 & 5 & 1.1 & -- \\
\hline $06 \ldots$ & 1535 & 349 & 337 & 21.5 & 24.0 & 10 & 9.4 & -- \\
\hline $07 \ldots$ & 1450 & 358 & 359 & 24.0 & 23.0 & 14 & 14 & 62 \\
\hline $08 \ldots$ & 1820 & 199 & 359 & 25.5 & 22.5 & 6 & 3.2 & -- \\
\hline $09 \ldots$ & 1455 & 147 & 379 & 28.0 & 24.0 & 5 & 2.0 & -- \\
\hline $11 \ldots$ & 1100 & 107 & 361 & 25.5 & 23.5 & 2 & .58 & -- \\
\hline $14 \ldots$ & 1135 & 86 & 370 & 26.0 & 24.5 & 3 & .70 & -- \\
\hline $17 \ldots$ & 1110 & 81 & 395 & 27.5 & 26.0 & 6 & 1.3 & -- \\
\hline $20 \ldots$ & 1015 & 69 & 443 & 18.0 & 22.5 & 4 & .75 & -- \\
\hline $22 \ldots$ & 1140 & 64 & 457 & 23.0 & 23.0 & 5 & .86 & -- \\
\hline $25 \ldots$ & 1245 & 62 & 470 & 19.5 & 21.5 & 7 & 1.2 & -- \\
\hline \multicolumn{9}{|l|}{ SEP } \\
\hline $01 \ldots$ & 1530 & 67 & 474 & -- & -- & 6 & 1.1 & -- \\
\hline $05 \ldots$ & 1450 & 60 & 524 & -- & -- & 2 & .32 & -- \\
\hline $08 \ldots$ & 1310 & 60 & 542 & 15.0 & 20.0 & 5 & .81 & -- \\
\hline $10 \ldots$ & 1740 & 71 & 539 & 15.0 & 18.5 & 3 & .58 & -- \\
\hline $13 \ldots$ & 1705 & 67 & 517 & 19.5 & 18.0 & 3 & .54 & -- \\
\hline $14 \ldots$ & 1240 & 81 & 553 & 26.5 & 19.5 & 2 & .44 & -- \\
\hline $21 \ldots$ & 1345 & 75 & 550 & 18.5 & 16.5 & 3 & .61 & -- \\
\hline $23 \ldots$ & 1220 & 172 & 489 & 14.0 & 16.0 & 4 & 1.9 & -- \\
\hline $23 \ldots$ & 1515 & 221 & 528 & 14.5 & 16.0 & 8 & 4.8 & -- \\
\hline $25 \ldots$ & 1135 & 147 & 472 & 15.0 & 15.5 & 2 & .79 & -- \\
\hline $28 \ldots$ & 1145 & 135 & 469 & 16.0 & 16.0 & 1 & .36 & -- \\
\hline
\end{tabular}

\begin{tabular}{|c|c|c|c|c|c|c|c|c|}
\hline \multicolumn{9}{|c|}{ WATER-QUALITY DATA, WATER YEAR OCTOBER 1995 TO SEPTEMBER 1996} \\
\hline \multicolumn{9}{|l|}{ OCT } \\
\hline $02 \ldots$ & 1640 & 132 & 433 & 24.0 & 16.0 & 2 & 0.71 & -- \\
\hline $05 \ldots$ & 1420 & 224 & 452 & 17.0 & 16.0 & 2 & 1.2 & -- \\
\hline $06 \ldots$ & 1010 & 588 & 443 & 12.0 & 15.5 & 20 & 32 & 81 \\
\hline $06 \ldots$ & 1320 & 638 & 458 & -- & 15.5 & 11 & 19 & -- \\
\hline $06 \ldots$ & 1735 & 664 & 408 & -- & 16.0 & 12 & 22 & -- \\
\hline $07 \ldots$ & 1315 & 644 & 341 & 13.0 & 14.5 & 10 & 17 & -- \\
\hline $08 \ldots$ & 1210 & 547 & 291 & 14.0 & 14.0 & 8 & 12 & -- \\
\hline $11 \ldots$ & 1510 & 221 & 287 & 20.5 & 14.0 & 4 & 2.4 & -- \\
\hline $15 \ldots$ & 1240 & 479 & 355 & 12.0 & 15.0 & 6 & 7.8 & -- \\
\hline $19 \ldots$ & 1640 & 221 & 311 & 20.0 & 11.5 & 3 & 1.8 & -- \\
\hline $21 \ldots$ & 1550 & 256 & 302 & 19.0 & 14.5 & 8 & 5.5 & -- \\
\hline $22 \ldots$ & 0237 & 1350 & 342 & -- & 14.0 & 22 & 80 & 68 \\
\hline $22 \ldots$ & 0239 & 1350 & 334 & -- & 14.0 & 30 & 109 & -- \\
\hline $22 \ldots$ & 0758 & 1490 & 246 & -- & 12.0 & 29 & 117 & 72 \\
\hline $22 \ldots$ & 1544 & 1690 & 255 & -- & 13.0 & 28 & 128 & -- \\
\hline $22 \ldots$ & 1208 & 1610 & 218 & -- & 13.5 & 33 & 143 & 45 \\
\hline $22 \ldots$ & 1211 & 1610 & 228 & -- & 13.5 & 30 & 130 & -- \\
\hline $23 \ldots$ & 0935 & 1920 & 148 & -- & 11.5 & 69 & 358 & 80 \\
\hline $23 \ldots$ & 0941 & 1920 & 148 & -- & 11.5 & 34 & 176 & -- \\
\hline $23 \ldots$ & 1829 & 1820 & 159 & -- & -- & 23 & 113 & -- \\
\hline $23 \ldots$ & 1831 & 1820 & 155 & -- & -- & 21 & 104 & 76 \\
\hline $26 \ldots$ & 0949 & 625 & 238 & -- & 10.5 & 4 & 6.8 & -- \\
\hline
\end{tabular}


Appendix 2. Instantaneous suspended-sediment and associated data at three continuous-record and four partial-record sediment stations in the Housatonic River Basin, western Massachusetts, March 1994 through April 1996-Continued

\begin{tabular}{|c|c|c|c|c|c|c|c|c|}
\hline DATE & TIME & $\begin{array}{c}\text { DISCHARGE, } \\
\text { INST. CUBIC } \\
\text { FEET PER } \\
\text { SECOND } \\
(00061)\end{array}$ & $\begin{array}{c}\text { SPECIFIC } \\
\text { CONDUC- } \\
\text { TANCE LAB } \\
\text { (US/CM) } \\
(90095)\end{array}$ & $\begin{array}{l}\text { TEMPERA- } \\
\text { TURE AIR } \\
\text { (DEG C) } \\
\text { (00020) }\end{array}$ & $\begin{array}{l}\text { TEMPERA- } \\
\text { TURE WATER } \\
\text { (DEG C) } \\
(00010)\end{array}$ & $\begin{array}{c}\text { SEDIMENT, } \\
\text { SUSPENDED } \\
(M G / L) \\
(80154)\end{array}$ & $\begin{array}{c}\text { SEDIMENT, } \\
\text { DISCHARGE, } \\
\text { SUSPENDED } \\
\text { (T/DAY) } \\
(80155)\end{array}$ & $\begin{array}{l}\text { SED. SUSP. } \\
\text { SIEVE DIAM. } \\
\text { \% FINER THAN } \\
.062 \text { MM } \\
(70331)\end{array}$ \\
\hline
\end{tabular}

01197500 - HOUSATONIC RIVER NEAR GREAT BARRINGTON, MA-Continued WATER-QUALITY DATA, WATER YEAR OCTOBER 1995 TO SEPTEMBER 1996-Continued

\begin{tabular}{|c|c|c|c|c|c|c|c|c|}
\hline \multicolumn{9}{|c|}{ OCT_CContinued } \\
\hline $28 \ldots$ & 1705 & 1860 & 219 & 13.5 & 13.0 & 24 & 121 & 38 \\
\hline $28 \ldots$ & 1710 & 1860 & 220 & 13.5 & 13.0 & 32 & 161 & -- \\
\hline $28 \ldots$ & 2139 & 2060 & 189 & -- & 12.5 & 32 & 178 & -- \\
\hline $29 \ldots$ & 0743 & 2370 & 155 & -- & 11.0 & 48 & 307 & 46 \\
\hline $29 \ldots$ & 0745 & 2370 & 154 & -- & 11.0 & 37 & 237 & $\ldots$ \\
\hline $29 \ldots$ & 1430 & 2300 & 161 & 10.0 & 11.5 & 26 & 161 & \\
\hline $30 \ldots$ & 1210 & 1800 & 171 & 9.0 & 9.5 & 17 & 83 & - \\
\hline \multicolumn{8}{|l|}{ NOV } & \\
\hline $02 \ldots$ & 1510 & 744 & 238 & 11.0 & 8.5 & 9 & 18 & \\
\hline $07 \ldots$ & 1545 & 513 & 259 & -- & 6.0 & 7 & 9.7 & \\
\hline $11 \ldots$ & 1120 & 524 & 257 & 14.5 & 5.0 & 3 & 4.2 & -- \\
\hline $12 \ldots$ & 1045 & 1620 & 262 & 1.0 & 6.5 & 18 & 79 & - \\
\hline $12 \ldots$ & 1440 & 1740 & 231 & 1.5 & 7.5 & 32 & 150 & \\
\hline $13 \ldots$ & 1230 & 2330 & 159 & 1.5 & 5.0 & 24 & 151 & \\
\hline $13 \ldots$ & 1235 & 2330 & 156 & 1.5 & 5.0 & 26 & 164 & -- \\
\hline $13 \ldots$ & 1655 & 2390 & 151 & 0.0 & 5.0 & 25 & 161 & - \\
\hline $14 \ldots$ & 1455 & 2000 & 157 & 3.0 & 4.0 & 18 & 97 & \\
\hline $15 \ldots$ & 1052 & 1900 & 208 & -- & 5.0 & 12 & 62 & 66 \\
\hline $18 \ldots$ & 1610 & 1220 & 215 & 1.5 & 3.0 & 8 & 26 & - \\
\hline $20 \ldots$ & 1350 & 1040 & 260 & 3.0 & 3.5 & 8 & 22 & - \\
\hline $27 \ldots$ & 1435 & 462 & 282 & 7.0 & 3.0 & 10 & 12 & - \\
\hline $30 \ldots$ & 1420 & 535 & 288 & -.5 & 2.5 & 2 & 2.9 & -- \\
\hline \multicolumn{8}{|l|}{ DEC } & \\
\hline $16 \ldots$ & 1550 & 408 & 313 & 1.5 & .5 & 3 & 3.3 & . \\
\hline $29 \ldots$ & 1620 & 312 & 312 & -1.0 & .5 & 4 & 3.4 & - \\
\hline \multicolumn{8}{|l|}{ JAN } & \\
\hline $20 \ldots$ & 0148 & 3330 & 301 & -- & .0 & 112 & 1010 & . \\
\hline $20 \ldots$ & 0150 & 3330 & 295 & -- & .0 & 113 & 1020 & - \\
\hline $20 \ldots$ & 1250 & 3910 & 265 & -- & .0 & 78 & 823 & -- \\
\hline $20 \ldots$ & 1252 & 3910 & 262 & -- & .0 & 68 & 718 & -- \\
\hline $20 \ldots$ & 1652 & 4080 & 235 & -- & .0 & 68 & 749 & \\
\hline $20 \ldots$ & 1654 & 4080 & 238 & -- & .0 & 80 & 881 & 66 \\
\hline $21 \ldots$ & 1052 & 4130 & 179 & -- & .0 & 28 & 312 & -- \\
\hline $21 \ldots$ & 1056 & 4140 & 186 & -- & .0 & 41 & 458 & 63 \\
\hline $22 \ldots$ & 1535 & 2650 & 189 & 3.5 & .5 & 14 & 100 & -- \\
\hline $23 \ldots$ & 1515 & 1720 & 208 & 2.5 & .5 & 7 & 33 & -- \\
\hline $25 \ldots$ & 0859 & 2430 & 213 & -- & .0 & 22 & 144 & -- \\
\hline $25 \ldots$ & 0901 & 2430 & 212 & -- & .0 & 17 & 112 & \\
\hline $26 \ldots$ & 1545 & 2370 & 186 & 1.0 & .0 & 9 & 58 & - \\
\hline $28 \ldots$ & 1335 & 3940 & 168 & -- & .5 & 42 & 447 & 61 \\
\hline $28 \ldots$ & 1401 & 3950 & 164 & -- & .5 & 41 & 437 & 65 \\
\hline $28 \ldots$ & 1402 & 3950 & 167 & -- & .5 & 48 & 512 & 80 \\
\hline $29 \ldots$ & 1030 & 3530 & 153 & -- & .0 & 24 & 229 & -- \\
\hline $29 \ldots$ & 1041 & 3530 & 154 & -- & .0 & 25 & 238 & - \\
\hline \multicolumn{8}{|l|}{ FEB } & \\
\hline $21 \ldots$ & 0954 & 664 & 349 & -- & 1.0 & 2 & 3.6 & \\
\hline $22 \ldots$ & 1420 & 1630 & 405 & -- & 2.5 & 17 & 75 & \\
\hline $22 \ldots$ & 1837 & 1780 & 323 & -- & 2.0 & 32 & 154 & - \\
\hline $22 \ldots$ & 1840 & 1780 & 322 & -- & 2.0 & 26 & 125 & \\
\hline
\end{tabular}


Appendix 2. Instantaneous suspended-sediment and associated data at three continuous-record and four partial-record sediment stations in the Housatonic River Basin, western Massachusetts, March 1994 through April 1996—Continued

\begin{tabular}{|c|c|c|c|c|c|c|c|c|}
\hline DATE & TIME & $\begin{array}{c}\text { DISCHARGE, } \\
\text { INST. CUBIC } \\
\text { FEET PER } \\
\text { SECOND } \\
(00061)\end{array}$ & $\begin{array}{c}\text { SPECIFIC } \\
\text { CONDUC- } \\
\text { TANCE LAB } \\
(\text { US/CM) } \\
(90095)\end{array}$ & $\begin{array}{c}\text { TEMPERA- } \\
\text { TURE AIR } \\
\text { (DEG C) } \\
(00020)\end{array}$ & $\begin{array}{l}\text { TEMPERA- } \\
\text { TURE WATER } \\
\text { (DEG C) } \\
(00010)\end{array}$ & $\begin{array}{c}\text { SEDIMENT, } \\
\text { SUSPENDED } \\
\text { (MG/L) } \\
(\mathbf{8 0 1 5 4 )}\end{array}$ & $\begin{array}{c}\text { SEDIMENT, } \\
\text { DISCHARGE, } \\
\text { SUSPENDED } \\
\text { (T/DAY) } \\
(\mathbf{8 0 1 5 5 )}\end{array}$ & $\begin{array}{l}\text { SED. SUSP. } \\
\text { SIEVE DIAM. } \\
\text { \% FINER THAN } \\
.062 \text { MM } \\
(70331)\end{array}$ \\
\hline \multicolumn{9}{|c|}{$\begin{array}{l}\text { 01197500 - HOUSATONIC RIVER NEAR GREAT BARRINGTON, MA-Continued } \\
\text { WATER-QUALITY DATA, WATER YEAR OCTOBER } 1995 \text { TO SEPTEMBER 1996-Continued }\end{array}$} \\
\hline \multicolumn{9}{|c|}{ FEB-Continued } \\
\hline $23 \ldots$ & 1120 & 1980 & 210 & -- & 3.0 & 18 & 96 & -- \\
\hline $24 \ldots$ & 1425 & 2000 & 190 & 8.5 & 2.0 & 9 & 49 & -- \\
\hline $24 \ldots$ & 1430 & 2000 & 193 & 8.5 & 2.0 & 12 & 65 & -- \\
\hline $26 \ldots$ & 1450 & 1570 & 192 & 8.5 & 2.5 & 6 & 25 & -- \\
\hline $27 \ldots$ & 1342 & 1330 & 202 & -- & 3.5 & 4 & 14 & -- \\
\hline \multicolumn{9}{|l|}{ MAR } \\
\hline $13 \ldots$ & 1555 & 619 & 331 & 9.5 & 3.5 & 3 & 5.0 & -- \\
\hline $20 \ldots$ & 1825 & 896 & 278 & -- & 4.5 & 6 & 15 & -- \\
\hline $24 \ldots$ & 0845 & 723 & 256 & -.5 & 2.5 & 6 & 12 & -- \\
\hline $28 \ldots$ & 1515 & 807 & 226 & 6.0 & 4.5 & 13 & 28 & -- \\
\hline \multicolumn{9}{|l|}{ APR } \\
\hline $01 \ldots$ & 1005 & 644 & 259 & -- & 8.0 & 5 & 8.7 & -- \\
\hline $01 \ldots$ & 1023 & 651 & 255 & -- & 7.5 & 7 & 12 & -- \\
\hline
\end{tabular}

01197802 - WILLIAMS RIVER, AT RAILROAD BRIDGE, NEAR GREAT BARRINGTON, MA WATER-QUALITY DATA, WATER YEAR OCTOBER 1993 TO SEPTEMBER 1994

\begin{tabular}{|c|c|c|c|c|c|c|c|c|}
\hline \multicolumn{9}{|l|}{ MAR } \\
\hline $31 \ldots$ & 1350 & 246 & -- & 6.0 & 4.5 & 6 & 4.0 & -- \\
\hline \multicolumn{9}{|l|}{ APR } \\
\hline $07 \ldots$ & 1800 & 539 & -- & -- & -- & 32 & 47 & -- \\
\hline $07 \ldots$ & 1805 & 539 & -- & -- & -- & 34 & 49 & 50 \\
\hline $08 \ldots$ & 1300 & 482 & -- & -- & -- & 20 & 26 & -- \\
\hline \multicolumn{9}{|l|}{ JUL } \\
\hline $15 \ldots$ & 0855 & 13 & 398 & 19.0 & 20.5 & 2 & .07 & -- \\
\hline \multicolumn{9}{|l|}{ AUG } \\
\hline $04 \ldots$ & 0900 & 17 & 377 & 24.5 & 22.0 & 2 & .09 & -- \\
\hline $18 \ldots$ & 1945 & 40 & 379 & -- & 19.5 & 7 & .76 & -- \\
\hline \multicolumn{9}{|c|}{ WATER-QUALITY DATA, WATER YEAR OCTOBER 1994 TO SEPTEMBER 1995} \\
\hline \multicolumn{9}{|l|}{ DEC } \\
\hline $06 \ldots$ & 1415 & 134 & 325 & -- & 5.5 & 10 & 3.6 & 64 \\
\hline \multicolumn{9}{|l|}{ MAR } \\
\hline $14 \ldots$ & 0935 & 206 & 300 & 8.5 & 4.0 & 4 & 2.2 & 80 \\
\hline \multicolumn{9}{|l|}{ AUG } \\
\hline $21 \ldots$ & 1330 & 3.8 & 366 & 28.5 & 22.5 & 2 & .02 & -- \\
\hline $25 \ldots$ & 1300 & 2.6 & 403 & 19.0 & 18.5 & 1 & .01 & -- \\
\hline \multicolumn{9}{|l|}{ SEP } \\
\hline $01 \ldots$ & 1835 & 1.5 & 410 & -- & -- & 1 & .00 & -- \\
\hline $05 \ldots$ & 1440 & 1.6 & 420 & -- & -- & 1 & .00 & -- \\
\hline $08 \ldots$ & 1320 & 1.2 & 404 & 15.5 & 17.0 & 2 & .01 & -- \\
\hline $10 \ldots$ & 1750 & 1.9 & 416 & 15.5 & 18.0 & 2 & .01 & -- \\
\hline $13 \ldots$ & 1650 & 2.4 & 421 & 18.0 & 16.5 & 1 & .01 & -- \\
\hline $21 \ldots$ & 1330 & 4.1 & 387 & 17.0 & 15.0 & 1 & 0.01 & -- \\
\hline $23 \ldots$ & 1210 & 9.4 & 393 & 12.5 & 14.5 & 2 & .05 & -- \\
\hline $25 \ldots$ & 1145 & 6.9 & 420 & 14.0 & 13.0 & 1 & .02 & -- \\
\hline $28 \ldots$ & 1510 & 5.8 & 425 & 17.5 & 17.0 & 2 & .03 & -- \\
\hline
\end{tabular}


Appendix 2. Instantaneous suspended-sediment and associated data at three continuous-record and four partial-record sediment stations in the Housatonic River Basin, western Massachusetts, March 1994 through April 1996-Continued

\begin{tabular}{|c|c|c|c|c|c|c|c|c|}
\hline DATE & TIME & $\begin{array}{l}\text { DISCHARGE, } \\
\text { INST. CUBIC } \\
\text { FEET PER } \\
\text { SECOND } \\
(00061) \\
\end{array}$ & $\begin{array}{c}\text { SPECIFIC } \\
\text { CONDUC- } \\
\text { TANCE LAB } \\
(\text { US/CM) } \\
(90095)\end{array}$ & $\begin{array}{c}\text { TEMPERA- } \\
\text { TURE AIR } \\
\text { (DEG C) } \\
(00020)\end{array}$ & $\begin{array}{l}\text { TEMPERA- } \\
\text { TURE WATER } \\
\text { (DEG C) } \\
\text { (00010) }\end{array}$ & $\begin{array}{c}\text { SEDIMENT, } \\
\text { SUSPENDED } \\
\text { (MG/L) } \\
(\mathbf{8 0 1 5 4 )}\end{array}$ & $\begin{array}{c}\text { SEDIMENT, } \\
\text { DISCHARGE, } \\
\text { SUSPENDED } \\
\text { (T/DAY) } \\
(\mathbf{8 0 1 5 5 )} \\
\end{array}$ & $\begin{array}{l}\text { SED. SUSP. } \\
\text { SIEVE DIAM. } \\
\text { \% FINER THAN } \\
.062 \text { MM } \\
(\mathbf{7 0 3 3 1})\end{array}$ \\
\hline \multicolumn{9}{|c|}{$\begin{array}{l}01197802 \text { - WILLIAMS RIVER, AT RAILROAD BRIDGE, NEAR GREAT BARRINGTON, MA-Continued } \\
\text { WATER-QUALITY DATA, WATER YEAR OCTOBER } 1995 \text { TO SEPTEMBER } 1996\end{array}$} \\
\hline \multicolumn{9}{|l|}{ OCT } \\
\hline $02 \ldots$ & 1625 & 3.6 & 407 & 23.5 & 16.5 & 6 & 0.06 & -- \\
\hline $05 \ldots$ & 1440 & 4.9 & 391 & -- & 15.5 & 3 & .04 & -- \\
\hline $05 \ldots$ & 2115 & 9.9 & 374 & -- & 14.5 & 2 & .05 & -- \\
\hline $06 \ldots$ & 0645 & 47 & 337 & -- & 14.0 & 34 & 4.3 & 66 \\
\hline $06 \ldots$ & 0650 & 47 & 337 & -- & 14.0 & 18 & 2.3 & -- \\
\hline $06 \ldots$ & 0932 & 63 & 369 & -- & 13.5 & 22 & 3.7 & -- \\
\hline $06 \ldots$ & 0943 & 63 & 346 & -- & 13.5 & 13 & 2.2 & -- \\
\hline $06 \ldots$ & 0945 & 63 & 360 & 12.5 & 13.5 & 46 & 7.8 & 30 \\
\hline $06 \ldots$ & 1334 & 70 & 354 & -- & 14.0 & 11 & 2.1 & -- \\
\hline $06 \ldots$ & 1550 & 68 & 355 & -- & 15.0 & 9 & 1.7 & -- \\
\hline $08 \ldots$ & 1215 & 38 & 404 & 14.5 & 14.0 & 3 & .31 & -- \\
\hline $11 \ldots$ & 1520 & 12 & 401 & 20.5 & 14.5 & 5 & .16 & -- \\
\hline $15 \ldots$ & 1230 & 16 & 409 & 13.0 & 14.0 & 4 & .17 & -- \\
\hline $20 \ldots$ & 1515 & 13 & 430 & 15.5 & 12.0 & 4 & .14 & -- \\
\hline $21 \ldots$ & 1540 & 19 & 408 & 19.0 & 15.0 & 5 & .26 & -- \\
\hline $22 \ldots$ & 0032 & 78 & 335 & -- & 13.5 & 26 & 5.5 & 39 \\
\hline $22 \ldots$ & 0252 & 82 & 348 & -- & 12.0 & 14 & 3.1 & -- \\
\hline $22 \ldots$ & 0810 & 116 & 372 & -- & 11.0 & 25 & 7.8 & -- \\
\hline $22 \ldots$ & 1225 & 135 & 382 & -- & 13.0 & 20 & 7.3 & 67 \\
\hline $22 \ldots$ & 1555 & 139 & 378 & -- & 13.0 & 18 & 6.8 & -- \\
\hline $23 \ldots$ & 0958 & 111 & 375 & -- & 11.0 & 6 & 1.8 & -- \\
\hline $26 \ldots$ & 1022 & 44 & 372 & -- & 10.5 & 3 & .36 & -- \\
\hline $28 \ldots$ & 1010 & 70 & 338 & -- & 12.5 & 5 & .94 & -- \\
\hline $28 \ldots$ & 1645 & 114 & 309 & 15.5 & 12.5 & 7 & 2.2 & -- \\
\hline $29 \ldots$ & 1420 & 139 & 341 & 10.5 & 11.0 & 4 & 1.5 & -- \\
\hline \multicolumn{9}{|l|}{ NOV } \\
\hline $02 \ldots$ & 1500 & 73 & 339 & 11.5 & 8.5 & 3 & .59 & -- \\
\hline $07 \ldots$ & 1555 & 54 & 360 & -- & 5.5 & 3 & .44 & -- \\
\hline $11 \ldots$ & 1130 & 55 & 357 & 14.5 & 5.0 & 2 & .30 & -- \\
\hline $12 \ldots$ & 0755 & 166 & 289 & -- & 6.0 & 23 & 10 & 77 \\
\hline $12 \ldots$ & 1035 & 157 & 311 & 1.5 & 6.5 & 9 & 3.8 & -- \\
\hline $12 \ldots$ & 1430 & 176 & 286 & 3.0 & 6.5 & 12 & 5.7 & -- \\
\hline $12 \ldots$ & 1815 & 229 & 304 & -- & 5.5 & 37 & 23 & -- \\
\hline $12 \ldots$ & 1818 & 229 & 291 & -- & 5.5 & 40 & 25 & 46 \\
\hline $13 \ldots$ & 1220 & 295 & 273 & 2.0 & 4.0 & 17 & 14 & 60 \\
\hline $13 \ldots$ & 1645 & 315 & 255 & .0 & 4.0 & 38 & 32 & 29 \\
\hline $14 \ldots$ & 1505 & 204 & 293 & 2.0 & 4.0 & 7 & 3.9 & -- \\
\hline $15 \ldots$ & 1108 & 193 & 307 & -- & 5.0 & 5 & 2.6 & -- \\
\hline $18 \ldots$ & 1555 & 157 & 312 & 1.5 & 3.0 & 2 & .85 & -- \\
\hline $20 \ldots$ & 1400 & 149 & 321 & 4.0 & 4.0 & 3 & 1.2 & -- \\
\hline $27 \ldots$ & 1540 & 79 & 360 & 6.5 & 3.0 & 2 & 0.43 & -- \\
\hline $30 \ldots$ & 1510 & 66 & 362 & -.5 & 1.5 & 3 & .53 & -- \\
\hline \multicolumn{9}{|l|}{ DEC } \\
\hline $10 \ldots$ & 1355 & 49 & 373 & -6.0 & .0 & 6 & .79 & -- \\
\hline $16 \ldots$ & 1515 & 46 & 379 & 1.5 & .0 & 9 & 1.1 & -- \\
\hline $29 \ldots$ & 1610 & 35 & 383 & -1.0 & .0 & 3 & .28 & -- \\
\hline \multicolumn{9}{|l|}{ JAN } \\
\hline $19 \ldots$ & 1510 & 312 & 307 & -- & 2.0 & 38 & 32 & -- \\
\hline $19 \ldots$ & 1946 & 900 & 253 & -- & .5 & 89 & 216 & -- \\
\hline
\end{tabular}


Appendix 2. Instantaneous suspended-sediment and associated data at three continuous-record and four partial-record sediment stations in the Housatonic River Basin, western Massachusetts, March 1994 through April 1996-Continued

\begin{tabular}{|c|c|c|c|c|c|c|c|c|}
\hline DATE & TIME & $\begin{array}{c}\text { DISCHARGE, } \\
\text { INST. CUBIC } \\
\text { FEET PER } \\
\text { SECOND } \\
(00061)\end{array}$ & $\begin{array}{c}\text { SPECIFIC } \\
\text { CONDUC- } \\
\text { TANCE LAB } \\
\text { (US/CM) } \\
(90095)\end{array}$ & $\begin{array}{l}\text { TEMPERA- } \\
\text { TURE AIR } \\
\text { (DEG C) } \\
\text { (00020) }\end{array}$ & $\begin{array}{l}\text { TEMPERA- } \\
\text { TURE WATER } \\
\text { (DEG C) } \\
(00010)\end{array}$ & $\begin{array}{c}\text { SEDIMENT, } \\
\text { SUSPENDED } \\
\text { (MG/L) } \\
(\mathbf{8 0 1 5 4 )}\end{array}$ & $\begin{array}{c}\text { SEDIMENT, } \\
\text { DISCHARGE, } \\
\text { SUSPENDED } \\
\text { (T/DAY) } \\
(\mathbf{8 0 1 5 5 )}\end{array}$ & $\begin{array}{l}\text { SED. SUSP. } \\
\text { SIEVE DIAM. } \\
\text { \% FINER THAN } \\
.062 \text { MM } \\
(70331)\end{array}$ \\
\hline
\end{tabular}

01197802 - WILLIAMS RIVER, AT RAILROAD BRIDGE, NEAR GREAT BARRINGTON, MA-Continued WATER-QUALITY DATA, WATER YEAR OCTOBER 1995 TO SEPTEMBER 1996-Continued

\begin{tabular}{|c|c|c|c|c|c|c|c|c|}
\hline \multicolumn{9}{|c|}{ JAN-Continued } \\
\hline $20 \ldots$ & 0118 & 475 & 254 & -- & 0.0 & 71 & 91 & -- \\
\hline $20 \ldots$ & 1225 & 629 & 305 & -- & .0 & 82 & 139 & -- \\
\hline $20 \ldots$ & 1226 & 629 & 292 & -- & .0 & 80 & 136 & -- \\
\hline $20 \ldots$ & 1235 & 730 & 305 & -- & .0 & 334 & 658 & -- \\
\hline $20 \ldots$ & 1643 & 849 & 291 & -- & .5 & 174 & 399 & -- \\
\hline $20 \ldots$ & 1648 & 849 & 282 & -- & .5 & 168 & 385 & -- \\
\hline $21 \ldots$ & 1102 & 559 & 264 & -- & .0 & 59 & 89 & -- \\
\hline $21 \ldots$ & 1103 & 559 & 265 & -- & .0 & 94 & 142 & -- \\
\hline $22 \ldots$ & 1550 & 360 & 286 & 3.0 & .0 & 37 & 36 & -- \\
\hline $23 \ldots$ & 1530 & 269 & 304 & 2.0 & .0 & 22 & 16 & -- \\
\hline $24 \ldots$ & 1425 & 269 & 305 & -- & 2.0 & 26 & 19 & -- \\
\hline $25 \ldots$ & 0820 & 475 & 279 & -- & .0 & 21 & 27 & -- \\
\hline $25 \ldots$ & 0826 & 475 & 281 & -- & .0 & 26 & 33 & -- \\
\hline $25 \ldots$ & 1525 & 516 & 277 & -- & -.5 & 27 & 38 & -- \\
\hline $25 \ldots$ & 1530 & 516 & 276 & -- & -.5 & 26 & 36 & -- \\
\hline $26 \ldots$ & 1530 & 456 & 289 & 1.0 & .0 & 30 & 37 & -- \\
\hline $28 \ldots$ & 1148 & 788 & 236 & -- & 1.0 & 77 & 164 & 70 \\
\hline $28 \ldots$ & 1703 & 741 & 238 & -- & .5 & 50 & 100 & -- \\
\hline $28 \ldots$ & 1705 & 741 & 236 & -- & .5 & 52 & 104 & -- \\
\hline $29 \ldots$ & 1115 & 472 & 257 & -- & .0 & 30 & 38 & -- \\
\hline $29 \ldots$ & 1125 & 472 & 257 & -- & .0 & 21 & 27 & -- \\
\hline \multicolumn{9}{|l|}{ FEB } \\
\hline $21 \ldots$ & 1020 & 82 & 387 & -- & 1.5 & 6 & 1.3 & -- \\
\hline $22 \ldots$ & 1440 & 256 & 319 & -- & 2.0 & 23 & 16 & -- \\
\hline $22 \ldots$ & 1825 & 274 & 315 & -- & 1.5 & 26 & 19 & -- \\
\hline $23 \ldots$ & 1145 & 269 & 278 & -- & 2.0 & 7 & 5.1 & -- \\
\hline $24 \ldots$ & 1445 & 236 & 277 & 6.5 & 2.0 & 11 & 7.0 & -- \\
\hline $26 \ldots$ & 1320 & 200 & 297 & 8.5 & 3.0 & 6 & 3.2 & -- \\
\hline $27 \ldots$ & 1325 & 174 & 306 & -- & 3.5 & 3 & 1.4 & -- \\
\hline \multicolumn{9}{|l|}{ MAR } \\
\hline $13 \ldots$ & 1535 & 82 & 363 & 9.5 & 3.0 & 12 & 2.7 & -- \\
\hline $20 \ldots$ & 1805 & 127 & 341 & -- & 4.5 & 2 & .69 & -- \\
\hline $26 \ldots$ & 1300 & 113 & 336 & 11.0 & 8.0 & 4 & 1.2 & -- \\
\hline $29 \ldots$ & 1345 & 102 & 339 & 10.5 & 6.0 & 8 & 2.2 & -- \\
\hline \multicolumn{9}{|l|}{ APR } \\
\hline $01 \ldots$ & 1055 & 90 & 343 & -- & 8.0 & 1 & .24 & -- \\
\hline $01 \ldots$ & 1058 & 90 & 346 & -- & 8.0 & 3 & .73 & -- \\
\hline $02 \ldots$ & 1618 & 110 & 339 & -- & 8.5 & 6 & 1.8 & -- \\
\hline $02 \ldots$ & 1622 & 110 & 327 & -- & 8.5 & 2 & .59 & -- \\
\hline
\end{tabular}

01198000 - GREEN RIVER NEAR GREAT BARRINGTON, MA

WATER-QUALITY DATA, WATER YEAR OCTOBER 1993 TO SEPTEMBER 1994

\begin{tabular}{|c|c|c|c|c|c|c|c|c|}
\hline \multicolumn{9}{|l|}{ MAR } \\
\hline $24 \ldots$ & 1735 & 378 & -- & -- & -- & 25 & 26 & -- \\
\hline $24 \ldots$ & 1750 & 390 & -- & -- & -- & 24 & 25 & -- \\
\hline $24 \ldots$ & 1810 & 400 & -- & -- & -- & 25 & 27 & -- \\
\hline $25 \ldots$ & 1615 & 469 & -- & 2.0 & 3.5 & 33 & 42 & -- \\
\hline $28 \ldots$ & 1600 & 573 & -- & -- & 2.0 & 46 & 71 & -- \\
\hline $28 \ldots$ & 1605 & 573 & -- & -- & 2.0 & 46 & 71 & -- \\
\hline $28 \ldots$ & 1630 & 580 & -- & -- & 2.0 & 57 & 89 & -- \\
\hline
\end{tabular}


Appendix 2. Instantaneous suspended-sediment and associated data at three continuous-record and four partial-record sediment stations in the Housatonic River Basin, western Massachusetts, March 1994 through April 1996-Continued

\begin{tabular}{|c|c|c|c|c|c|c|c|c|}
\hline DATE & TIME & $\begin{array}{c}\text { DISCHARGE, } \\
\text { INST. CUBIC } \\
\text { FEET PER } \\
\text { SECOND } \\
(00061)\end{array}$ & $\begin{array}{c}\text { SPECIFIC } \\
\text { CONDUC- } \\
\text { TANCE LAB } \\
\text { (US/CM) } \\
(90095)\end{array}$ & $\begin{array}{c}\text { TEMPERA- } \\
\text { TURE AIR } \\
\text { (DEG C) } \\
\text { (00020) }\end{array}$ & $\begin{array}{l}\text { TEMPERA- } \\
\text { TURE WATER } \\
\text { (DEG C) } \\
(00010)\end{array}$ & $\begin{array}{c}\text { SEDIMENT, } \\
\text { SUSPENDED } \\
\text { (MG/L) } \\
(\mathbf{8 0 1 5 4 )}\end{array}$ & $\begin{array}{c}\text { SEDIMENT, } \\
\text { DISCHARGE, } \\
\text { SUSPENDED } \\
(\text { T/DAY) } \\
(\mathbf{8 0 1 5 5 )}\end{array}$ & $\begin{array}{l}\text { SED. SUSP. } \\
\text { SIEVE DIAM. } \\
\text { \% FINER THAN } \\
.062 \text { MM } \\
(\mathbf{7 0 3 3 1})\end{array}$ \\
\hline
\end{tabular}

01198000 - GREEN RIVER NEAR GREAT BARRINGTON, MA-Continued

WATER-QUALITY DATA, WATER YEAR OCTOBER 1993 TO SEPTEMBER 1994—Continued

\begin{tabular}{|c|c|c|c|c|c|c|c|c|}
\hline \multicolumn{9}{|c|}{ MAR-Continued } \\
\hline $29 \ldots$ & 1645 & 501 & -- & 3.5 & 2.0 & 15 & 20 & -- \\
\hline $29 \ldots$ & 1650 & 501 & -- & 3.5 & 2.0 & 16 & 22 & -- \\
\hline $30 \ldots$ & 1510 & 396 & -- & 5.0 & 4.0 & 9 & 9.6 & -- \\
\hline $31 \ldots$ & 1250 & 245 & -- & 6.5 & 4.0 & 13 & 8.6 & -- \\
\hline \multicolumn{9}{|l|}{ APR } \\
\hline $05 \ldots$ & 1755 & 523 & 145 & 16.5 & 7.5 & 11 & 16 & -- \\
\hline $05 \ldots$ & 1800 & 523 & 145 & 16.5 & 7.5 & 18 & 25 & -- \\
\hline $06 \ldots$ & 1205 & 531 & -- & 9.0 & 4.5 & 17 & 24 & 71 \\
\hline $07 \ldots$ & 1130 & 1160 & -- & -- & -- & 270 & 846 & 64 \\
\hline $07 \ldots$ & 1150 & 1170 & -- & -- & -- & 212 & 670 & 76 \\
\hline $07 \ldots$ & 1425 & 1000 & -- & -- & -- & 106 & 286 & 67 \\
\hline $07 \ldots$ & 1430 & 1000 & 111 & -- & -- & 115 & 310 & -- \\
\hline $07 \ldots$ & 1435 & 1000 & -- & -- & -- & 84 & 227 & 73 \\
\hline $07 \ldots$ & 1535 & 941 & 109 & -- & -- & 76 & 193 & -- \\
\hline $08 \ldots$ & 0800 & 576 & -- & 3.0 & 2.0 & 25 & 39 & 73 \\
\hline $08 \ldots$ & 0945 & 494 & 136 & -- & 2.0 & 16 & 21 & -- \\
\hline $08 \ldots$ & 0955 & 523 & 135 & -- & 2.0 & 15 & 21 & -- \\
\hline $08 \ldots$ & 1600 & 494 & 133 & 9.0 & 6.0 & 15 & 20 & -- \\
\hline $08 \ldots$ & 1630 & 494 & -- & 9.0 & 6.0 & 17 & 23 & 74 \\
\hline $14 \ldots$ & 1140 & 723 & -- & 14.0 & 6.0 & 33 & 64 & 74 \\
\hline $14 \ldots$ & 1200 & 701 & 128 & 14.0 & 6.0 & 26 & 49 & -- \\
\hline $14 \ldots$ & 1700 & 604 & 133 & 18.0 & 8.0 & 23 & 38 & -- \\
\hline $15 \ldots$ & 0825 & 462 & 139 & 6.5 & 5.0 & 12 & 15 & -- \\
\hline \multicolumn{9}{|l|}{ MAY } \\
\hline $05 \ldots$ & 0800 & 82 & 200 & -- & 9.0 & 4 & .89 & -- \\
\hline $05 \ldots$ & 0805 & 82 & 200 & -- & 9.0 & 1 & .22 & -- \\
\hline $13 \ldots$ & 1625 & 92 & 185 & 15.0 & 12.0 & 3 & .75 & -- \\
\hline $13 \ldots$ & 1630 & 92 & 197 & 15.0 & 12.0 & 1 & .25 & -- \\
\hline $19 \ldots$ & 1235 & 140 & 167 & 12.5 & 10.0 & 2 & .76 & -- \\
\hline $19 \ldots$ & 1240 & 140 & 176 & 12.5 & 10.0 & 3 & 1.1 & -- \\
\hline $28 \ldots$ & 1240 & 68 & 205 & 14.0 & 13.5 & 1 & .18 & -- \\
\hline $28 \ldots$ & 1245 & 68 & 194 & 14.0 & 13.5 & 7 & 1.3 & 67 \\
\hline \multicolumn{9}{|l|}{ JUN } \\
\hline $02 \ldots$ & 1220 & 46 & 225 & 15.0 & 12.5 & 1 & .12 & -- \\
\hline $02 \ldots$ & 1225 & 46 & 224 & 15.0 & 12.5 & 1 & .12 & -- \\
\hline $10 \ldots$ & 1120 & 31 & 245 & 21.0 & -- & 1 & .08 & -- \\
\hline $10 \ldots$ & 1125 & 31 & 245 & 21.0 & -- & 1 & .08 & -- \\
\hline $15 \ldots$ & 1550 & 32 & 223 & 27.5 & 21.0 & 3 & .26 & -- \\
\hline $15 \ldots$ & 1555 & 32 & 234 & 27.5 & 21.0 & 1 & .09 & -- \\
\hline $22 \ldots$ & 1035 & 21 & 256 & 19.0 & 15.0 & 6 & .34 & -- \\
\hline $22 \ldots$ & 1040 & 21 & 360 & 19.0 & 15.0 & ${ }^{1} 0$ & .01 & 100 \\
\hline $29 \ldots$ & 1055 & 17 & 263 & 24.5 & 16.0 & ${ }^{1} 0$ & .02 & -- \\
\hline $29 \ldots$ & 1100 & 17 & 252 & 24.5 & 16.0 & 3 & .14 & -- \\
\hline \multicolumn{9}{|l|}{ JUL } \\
\hline $07 \ldots$ & 0845 & 14 & 258 & 23.5 & 17.0 & 2 & .08 & -- \\
\hline $07 \ldots$ & 0850 & 14 & 265 & 23.5 & 17.0 & 4 & .15 & -- \\
\hline $14 \ldots$ & 1800 & 10 & 274 & -- & 20.5 & 1 & .03 & -- \\
\hline $14 \ldots$ & 1805 & 10 & 275 & -- & 20.5 & 5 & .14 & -- \\
\hline $14 \ldots$ & 1825 & 10 & 272 & -- & 20.5 & 3 & .08 & -- \\
\hline
\end{tabular}


Appendix 2. Instantaneous suspended-sediment and associated data at three continuous-record and four partial-record sediment stations in the Housatonic River Basin, western Massachusetts, March 1994 through April 1996-Continued

\begin{tabular}{|c|c|c|c|c|c|c|c|c|}
\hline DATE & TIME & $\begin{array}{c}\text { DISCHARGE, } \\
\text { INST. CUBIC } \\
\text { FEET PER } \\
\text { SECOND } \\
(00061)\end{array}$ & $\begin{array}{c}\text { SPECIFIC } \\
\text { CONDUC- } \\
\text { TANCE LAB } \\
\text { (US/CM) } \\
(90095)\end{array}$ & $\begin{array}{c}\text { TEMPERA- } \\
\text { TURE AIR } \\
\text { (DEG C) } \\
(00020)\end{array}$ & $\begin{array}{l}\text { TEMPERA- } \\
\text { TURE WATER } \\
\text { (DEG C) } \\
(00010)\end{array}$ & $\begin{array}{c}\text { SEDIMENT, } \\
\text { SUSPENDED } \\
\text { (MG/L) } \\
(\mathbf{8 0 1 5 4 )}\end{array}$ & $\begin{array}{c}\text { SEDIMENT, } \\
\text { DISCHARGE, } \\
\text { SUSPENDED } \\
\text { (T/DAY) } \\
(80155)\end{array}$ & $\begin{array}{l}\text { SED. SUSP. } \\
\text { SIEVE DIAM. } \\
\text { \% FINER THAN } \\
.062 \mathrm{MM} \\
(70331)\end{array}$ \\
\hline
\end{tabular}

01198000 - GREEN RIVER NEAR GREAT BARRINGTON, MA-Continued

WATER-QUALITY DATA, WATER YEAR OCTOBER 1993 TO SEPTEMBER 1994—Continued

\begin{tabular}{|c|c|c|c|c|c|c|c|c|}
\hline \multicolumn{9}{|c|}{ JUL-Continued } \\
\hline $21 \ldots$ & 1800 & 15 & 276 & 31.5 & 23.0 & 2 & 0.08 & -- \\
\hline $21 \ldots$ & 1805 & 15 & 275 & 31.5 & 23.0 & 1 & .04 & -- \\
\hline $27 \ldots$ & 1540 & 42 & 253 & 29.0 & 22.0 & 3 & .34 & -- \\
\hline $27 \ldots$ & 1545 & 42 & 261 & 29.0 & 22.0 & 6 & .68 & -- \\
\hline \multicolumn{9}{|l|}{ AUG } \\
\hline $04 \ldots$ & 1250 & 24 & 261 & 29.0 & 20.0 & 5 & .32 & -- \\
\hline $04 \ldots$ & 1255 & 24 & 268 & 29.0 & 20.0 & 3 & .19 & -- \\
\hline $04 \ldots$ & 1315 & 24 & 263 & 29.0 & 20.0 & 1 & .06 & -- \\
\hline $11 \ldots$ & 1745 & 15 & 276 & 23.0 & 18.0 & ${ }^{1} 0$ & .01 & -- \\
\hline $11 \ldots$ & 1750 & 15 & 272 & 23.0 & 18.0 & ${ }^{1} 0$ & .00 & -- \\
\hline $17 \ldots$ & 1245 & 15 & 293 & 21.5 & 16.0 & ${ }^{1} 0$ & .01 & -- \\
\hline $17 \ldots$ & 1250 & 15 & 293 & 21.5 & 16.0 & 4 & .16 & -- \\
\hline $18 \ldots$ & 1250 & 68 & 273 & 20.5 & 16.5 & 11 & 2.0 & -- \\
\hline $18 \ldots$ & 1550 & 67 & 252 & 20.5 & 16.5 & 6 & 1.1 & -- \\
\hline $18 \ldots$ & 1600 & 67 & 244 & 20.5 & 16.5 & 12 & 2.2 & -- \\
\hline $23 \ldots$ & 1445 & 68 & 245 & 22.0 & 17.5 & 3 & .55 & -- \\
\hline $23 \ldots$ & 1450 & 68 & 249 & 22.0 & 17.5 & 3 & .55 & -- \\
\hline $24 \ldots$ & 1005 & 54 & 245 & 15.0 & 13.5 & 2 & .29 & -- \\
\hline \multicolumn{9}{|l|}{ SEP } \\
\hline $01 \ldots$ & 1300 & 29 & 262 & 19.5 & 16.0 & 5 & .39 & -- \\
\hline $07 \ldots$ & 0825 & 19 & 284 & 10.0 & 12.5 & 5 & .26 & -- \\
\hline $07 \ldots$ & 0830 & 19 & 284 & 10.0 & 12.5 & 8 & .41 & -- \\
\hline $11 \ldots$ & 1305 & 29 & 271 & -- & -- & 3 & .23 & -- \\
\hline $15 \ldots$ & 1200 & 15 & 284 & 19.0 & 18.0 & 7 & .28 & -- \\
\hline $15 \ldots$ & 1205 & 15 & 289 & 19.0 & 18.0 & 8 & .32 & -- \\
\hline $21 \ldots$ & 1110 & 13 & 294 & -- & -- & 4 & .14 & -- \\
\hline $21 \ldots$ & 1112 & 13 & 298 & -- & -- & 5 & .18 & -- \\
\hline $28 \ldots$ & 1045 & 153 & 156 & 17.0 & 14.5 & 19 & 7.8 & -- \\
\hline $28 \ldots$ & 1110 & 151 & 166 & 17.0 & 14.5 & 13 & 5.3 & -- \\
\hline $30 \ldots$ & 1740 & 54 & 213 & 14.5 & 13.5 & 1 & .15 & - \\
\hline $30 \ldots$ & 1745 & 54 & 218 & 14.5 & 13.5 & 3 & .44 & - \\
\hline
\end{tabular}

\section{WATER-QUALITY DATA, WATER YEAR OCTOBER 1994 TO SEPTEMBER 1995}

\begin{tabular}{|c|c|c|c|c|c|c|c|c|}
\hline \multicolumn{9}{|l|}{ OCT } \\
\hline $04 \ldots$ & 1355 & 39 & 237 & 9.5 & 11.0 & 1 & 0.11 & -- \\
\hline $09 \ldots$ & 1203 & 30 & 246 & 19.0 & 13.0 & 1 & .08 & -- \\
\hline $15 \ldots$ & 0905 & 29 & 243 & 4.0 & 8.5 & 1 & .08 & -- \\
\hline $19 \ldots$ & 1025 & 26 & 253 & 11.5 & 11.0 & 2 & .14 & -- \\
\hline $19 \ldots$ & 1235 & 25 & 249 & 16.0 & 12.0 & 1 & .07 & -- \\
\hline $21 \ldots$ & 1205 & 30 & 254 & 15.0 & 12.0 & 6 & .49 & -- \\
\hline \multicolumn{9}{|l|}{ NOV } \\
\hline $01 \ldots$ & 1210 & 26 & 249 & 17.5 & 12.0 & 1 & 0.07 & -- \\
\hline $02 \ldots$ & 0855 & 30 & 247 & 5.0 & 10.0 & 2 & .16 & -- \\
\hline $08 \ldots$ & 1615 & 27 & 242 & 11.5 & 10.0 & ${ }^{1} 0$ & .02 & -- \\
\hline $15 \ldots$ & 1310 & 24 & 248 & 11.5 & 10.5 & 1 & .06 & -- \\
\hline $18 \ldots$ & 1125 & 27 & 242 & 11.0 & 8.5 & ${ }^{1} 0$ & .02 & -- \\
\hline $21 \ldots$ & 0945 & 21 & 251 & 5.5 & 6.0 & 1 & .06 & -- \\
\hline $26 \ldots$ & 1205 & 30 & 227 & 2.0 & 5.0 & 1 & .08 & -- \\
\hline $28 \ldots$ & 1725 & 84 & 228 & 12.5 & 4.5 & 43 & 9.8 & 43 \\
\hline
\end{tabular}


Appendix 2. Instantaneous suspended-sediment and associated data at three continuous-record and four partial-record sediment stations in the Housatonic River Basin, western Massachusetts, March 1994 through April 1996—Continued

\begin{tabular}{|c|c|c|c|c|c|c|c|c|}
\hline DATE & TIME & $\begin{array}{l}\text { DISCHARGE, } \\
\text { INST. CUBIC } \\
\text { FEET PER } \\
\text { SECOND } \\
(00061)\end{array}$ & $\begin{array}{c}\text { SPECIFIC } \\
\text { CONDUC- } \\
\text { TANCE LAB } \\
\text { (US/CM) } \\
(90095)\end{array}$ & $\begin{array}{c}\text { TEMPERA- } \\
\text { TURE AIR } \\
\text { (DEG C) } \\
(00020)\end{array}$ & $\begin{array}{l}\text { TEMPERA- } \\
\text { TURE WATER } \\
\text { (DEG C) } \\
(00010)\end{array}$ & $\begin{array}{c}\text { SEDIMENT, } \\
\text { SUSPENDED } \\
\text { (MG/L) } \\
(\mathbf{8 0 1 5 4 )}\end{array}$ & $\begin{array}{c}\text { SEDIMENT, } \\
\text { DISCHARGE, } \\
\text { SUSPENDED } \\
\text { (T/DAY) } \\
(\mathbf{8 0 1 5 5 )}\end{array}$ & $\begin{array}{l}\text { SED. SUSP. } \\
\text { SIEVE DIAM. } \\
\text { \% FINER THAN } \\
.062 \text { MM } \\
(70331)\end{array}$ \\
\hline \multicolumn{9}{|c|}{$\begin{array}{l}\text { 01198000 - GREEN RIVER NEAR GREAT BARRINGTON, MA-Continued } \\
\text { R-QUALITY DATA, WATER YEAR OCTOBER } 1994 \text { TO SEPTEMBER 1995-Continued }\end{array}$} \\
\hline \multicolumn{9}{|c|}{ NOV_Continued } \\
\hline $29 \ldots$ & 0815 & 145 & 154 & -1.5 & 3.0 & 12 & 4.7 & -- \\
\hline $29 \ldots$ & 1205 & 129 & 161 & 9.5 & 5.5 & 6 & 2.1 & -- \\
\hline $29 \ldots$ & 1215 & 129 & 158 & 9.5 & 5.5 & 7 & 2.4 & -- \\
\hline \multicolumn{9}{|l|}{ DEC } \\
\hline $05 \ldots$ & 1220 & 96 & 201 & 10.5 & 7.0 & 6 & 1.6 & -- \\
\hline $05 \ldots$ & 1625 & 178 & 190 & 8.0 & 6.5 & 45 & 22 & 50 \\
\hline $05 \ldots$ & 2110 & 345 & 133 & -- & 7.0 & 113 & 105 & 68 \\
\hline $06 \ldots$ & 0705 & 238 & 140 & 8.5 & 7.0 & 16 & 10 & 60 \\
\hline $06 \ldots$ & 1550 & 190 & 152 & 9.5 & 7.5 & 5 & 2.6 & -- \\
\hline $11 \ldots$ & 0940 & 202 & 173 & 2.5 & 4.0 & 10 & 5.5 & -- \\
\hline $11 \ldots$ & 1400 & 229 & 156 & 2.0 & 4.5 & 11 & 6.8 & -- \\
\hline $15 \ldots$ & 1400 & 105 & 190 & 5.0 & 4.0 & 1 & .28 & -- \\
\hline $18 \ldots$ & 1145 & 95 & 200 & 4.5 & 4.5 & 1 & .26 & -- \\
\hline $21 \ldots$ & 1640 & 73 & 205 & .0 & 4.0 & 2 & .39 & -- \\
\hline $24 \ldots$ & 0955 & 162 & 213 & 8.0 & 4.5 & 17 & 7.4 & -- \\
\hline $24 \ldots$ & 1345 & 245 & 159 & 6.5 & 5.0 & 41 & 27 & 76 \\
\hline $24 \ldots$ & 1655 & 280 & -- & 4.0 & 4.5 & 29 & 22 & 64 \\
\hline $28 \ldots$ & 1550 & 136 & 175 & 3.5 & 4.0 & 6 & 2.2 & -- \\
\hline \multicolumn{9}{|l|}{ JAN } \\
\hline $01 \ldots$ & 1455 & 180 & 182 & 5.0 & 3.5 & 10 & 4.9 & -- \\
\hline $09 \ldots$ & 1540 & 108 & 203 & -1.5 & 2.0 & 1 & .29 & -- \\
\hline $14 \ldots$ & 1045 & 151 & 172 & 6.0 & 3.0 & 4 & 1.6 & -- \\
\hline $16 \ldots$ & 2010 & 250 & 171 & 7.5 & 6.5 & 11 & 7.4 & 62 \\
\hline $21 \ldots$ & 1035 & 348 & 157 & 4.5 & 4.0 & 15 & 14 & 55 \\
\hline $21 \ldots$ & 1225 & 384 & 155 & 2.5 & 4.0 & 16 & 17 & 89 \\
\hline $21 \ldots$ & 1242 & 384 & 148 & 2.5 & 4.0 & 16 & 17 & 81 \\
\hline $26 \ldots$ & 1145 & 168 & 227 & -3.0 & 2.0 & 3 & 1.4 & -- \\
\hline $31 \ldots$ & 1600 & 106 & 210 & .0 & 3.0 & 1 & .29 & -- \\
\hline \multicolumn{9}{|l|}{ FEB } \\
\hline $09 \ldots$ & 1615 & 67 & 191 & -4.0 & 1.5 & 5 & .90 & -- \\
\hline $14 \ldots$ & 1605 & 56 & 172 & -4.5 & 1.5 & 1 & .15 & -- \\
\hline $16 \ldots$ & 1620 & 51 & 211 & 1.5 & 3.0 & 1 & .14 & -- \\
\hline $21 \ldots$ & 1330 & 48 & 225 & 1.5 & 3.5 & 2 & .26 & -- \\
\hline $24 \ldots$ & 1145 & 77 & 221 & .0 & 2.0 & 5 & 1.0 & 71 \\
\hline $28 \ldots$ & 1205 & 86 & 240 & 1.5 & 1.5 & 12 & 2.8 & -- \\
\hline $28 \ldots$ & 1945 & 111 & 224 & 1.0 & 2.0 & 13 & 3.9 & 58 \\
\hline \multicolumn{9}{|l|}{ MAR } \\
\hline $06 \ldots$ & 1215 & 78 & 217 & 5.0 & 3.5 & 2 & 0.42 & -- \\
\hline $08 \ldots$ & 1645 & 469 & 118 & 2.5 & 4.0 & 299 & 379 & 60 \\
\hline $10 \ldots$ & 1135 & 390 & 150 & 6.5 & .5 & 24 & 25 & 59 \\
\hline $13 \ldots$ & 1235 & 231 & 164 & 13.5 & 5.5 & 9 & 5.6 & -- \\
\hline $14 \ldots$ & 1200 & 257 & 156 & -- & 5.0 & 8 & 5.6 & -- \\
\hline $16 \ldots$ & 1705 & 250 & 155 & 11.0 & 7.5 & 6 & 4.0 & -- \\
\hline $21 \ldots$ & 1340 & 160 & 188 & 9.5 & 6.0 & 5 & 2.2 & -- \\
\hline $27 \ldots$ & 1640 & 100 & 183 & 10.5 & 8.0 & 2 & .54 & -- \\
\hline $31 \ldots$ & 1155 & 91 & 199 & 7.0 & 6.5 & 1 & .25 & -- \\
\hline \multicolumn{9}{|l|}{ APR } \\
\hline $03 \ldots$ & 1450 & 71 & 206 & 7.5 & 7.0 & 2 & .38 & -- \\
\hline $07 \ldots$ & 1140 & 63 & 210 & 4.5 & 4.5 & 1 & .17 & -- \\
\hline
\end{tabular}


Appendix 2. Instantaneous suspended-sediment and associated data at three continuous-record and four partial-record sediment stations in the Housatonic River Basin, western Massachusetts, March 1994 through April 1996-Continued

\begin{tabular}{|c|c|c|c|c|c|c|c|c|}
\hline DATE & TIME & $\begin{array}{c}\text { DISCHARGE, } \\
\text { INST. CUBIC } \\
\text { FEET PER } \\
\text { SECOND } \\
(00061)\end{array}$ & $\begin{array}{c}\text { SPECIFIC } \\
\text { CONDUC- } \\
\text { TANCE LAB } \\
\text { (US/CM) } \\
(90095)\end{array}$ & $\begin{array}{c}\text { TEMPERA- } \\
\text { TURE AIR } \\
\text { (DEG C) } \\
(00020)\end{array}$ & $\begin{array}{l}\text { TEMPERA- } \\
\text { TURE WATER } \\
\text { (DEG C) } \\
(00010)\end{array}$ & $\begin{array}{c}\text { SEDIMENT, } \\
\text { SUSPENDED } \\
\text { (MG/L) } \\
(\mathbf{8 0 1 5 4 )}\end{array}$ & $\begin{array}{l}\text { SEDIMENT, } \\
\text { DISCHARGE, } \\
\text { SUSPENDED } \\
\text { (T/DAY) } \\
(\mathbf{8 0 1 5 5 )}\end{array}$ & $\begin{array}{l}\text { SED. SUSP. } \\
\text { SIEVE DIAM. } \\
\text { \% FINER THAN } \\
.062 \text { MM } \\
(70331)\end{array}$ \\
\hline
\end{tabular}

01198000 - GREEN RIVER NEAR GREAT BARRINGTON, MA-Continued WATER-QUALITY DATA, WATER YEAR OCTOBER 1994 TO SEPTEMBER 1995-Continued

\begin{tabular}{|c|c|c|c|c|c|c|c|c|}
\hline \multicolumn{9}{|c|}{ APR-Continued } \\
\hline $12 \ldots$ & 1355 & 60 & 201 & 7.0 & 6.0 & 1 & 0.16 & -- \\
\hline $13 \ldots$ & 0700 & 194 & 191 & 6.0 & 6.5 & 56 & 29 & 89 \\
\hline $13 \ldots$ & 0704 & 194 & 185 & 6.0 & 6.5 & 61 & 32 & 67 \\
\hline $13 \ldots$ & 0712 & 194 & 184 & 6.0 & 6.5 & 43 & 23 & 97 \\
\hline $13 \ldots$ & 0915 & 196 & 156 & -- & 6.5 & 37 & 20 & 97 \\
\hline $13 \ldots$ & 1315 & 166 & 153 & -- & 8.0 & 14 & 6.3 & 82 \\
\hline $13 \ldots$ & 1415 & 160 & 156 & -- & 8.0 & 13 & 5.6 & 90 \\
\hline $14 \ldots$ & 1350 & 114 & 170 & 9.0 & 7.5 & 16 & 4.9 & -- \\
\hline $17 \ldots$ & 1425 & 86 & 167 & 13.0 & 9.5 & 2 & .46 & -- \\
\hline $19 \ldots$ & 1045 & 114 & 197 & 9.5 & 8.0 & 13 & 4.0 & 90 \\
\hline $19 \ldots$ & 1050 & 114 & 192 & 9.5 & 8.0 & 13 & 4.0 & -- \\
\hline $22 \ldots$ & 0945 & 110 & 178 & 12.5 & 8.0 & 2 & .59 & -- \\
\hline $30 \ldots$ & 1305 & 73 & 198 & 13.0 & 10.5 & 3 & .59 & -- \\
\hline \multicolumn{9}{|l|}{ MAY } \\
\hline $04 \ldots$ & 1245 & 60 & 209 & 18.5 & 12.0 & 4 & .65 & -- \\
\hline $10 \ldots$ & 1320 & 45 & 216 & 10.0 & 9.5 & 1 & .12 & -- \\
\hline $11 \ldots$ & 1140 & 49 & 217 & 10.0 & 8.5 & 2 & .26 & -- \\
\hline $11 \ldots$ & 1545 & 52 & 217 & 11.0 & 9.0 & 2 & .28 & -- \\
\hline $15 \ldots$ & 1245 & 45 & 223 & 12.0 & 10.0 & 2 & .24 & -- \\
\hline $19 \ldots$ & 1200 & 38 & 225 & 11.5 & 10.0 & 2 & .21 & -- \\
\hline $25 \ldots$ & 0915 & 43 & 241 & 15.5 & 13.0 & 2 & .23 & -- \\
\hline \multicolumn{9}{|l|}{ JUN } \\
\hline $02 \ldots$ & 1440 & 31 & 229 & 23.5 & 15.0 & 2 & .17 & -- \\
\hline $05 \ldots$ & 1150 & 39 & 215 & 21.5 & 14.5 & 1 & .11 & -- \\
\hline $13 \ldots$ & 1945 & 28 & 218 & 18.0 & 15.0 & 2 & .15 & -- \\
\hline $20 \ldots$ & 0945 & 16 & 249 & 26.0 & 16.0 & 2 & .09 & -- \\
\hline $20 \ldots$ & 0948 & 16 & 251 & 26.0 & 16.0 & 2 & .09 & -- \\
\hline $27 \ldots$ & 1028 & 14 & 265 & -- & 17.5 & 1 & .04 & -- \\
\hline \multicolumn{9}{|l|}{ JUL } \\
\hline $03 \ldots$ & 1630 & 14 & 246 & 23.5 & 20.0 & 5 & .19 & -- \\
\hline $07 \ldots$ & 1810 & 11 & 266 & 21.5 & 17.5 & 2 & .06 & -- \\
\hline $14 \ldots$ & 1045 & 25 & 232 & -- & 13.0 & 2 & .14 & -- \\
\hline $15 \ldots$ & 0815 & 8.4 & 281 & 21.5 & 17.5 & 2 & .05 & -- \\
\hline $21 \ldots$ & 1350 & 5.6 & 289 & 24.0 & 19.0 & 1 & .02 & -- \\
\hline $25 \ldots$ & 1345 & 6.0 & 275 & 27.5 & 20.5 & 1 & .02 & -- \\
\hline \multicolumn{9}{|l|}{ AUG } \\
\hline $04 \ldots$ & 1710 & 4.8 & 269 & 23.0 & 23.0 & 1 & .01 & -- \\
\hline $07 \ldots$ & 1520 & 7.0 & 286 & 25.5 & 23.0 & 1 & .02 & -- \\
\hline $08 \ldots$ & 1740 & 6.6 & 290 & 23.0 & 21.0 & 1 & .02 & -- \\
\hline $09 \ldots$ & 1610 & 6.0 & 292 & 28.5 & 22.0 & 2 & .03 & -- \\
\hline $11 \ldots$ & 0705 & 5.6 & 275 & 17.0 & 17.0 & 3 & .05 & -- \\
\hline $14 \ldots$ & 1205 & 5.1 & 293 & 25.0 & 20.0 & 1 & .01 & -- \\
\hline $17 \ldots$ & 1150 & 4.5 & 296 & 25.5 & 20.5 & 4 & .05 & -- \\
\hline $21 \ldots$ & 1430 & 3.3 & 298 & 32.0 & 23.0 & 1 & .01 & -- \\
\hline $24 \ldots$ & 1220 & 3.3 & 279 & 25.0 & 19.0 & 1 & .01 & -- \\
\hline \multicolumn{9}{|l|}{ SEP } \\
\hline $01 \ldots$ & 1600 & 2.8 & 298 & -- & -- & 1 & .01 & -- \\
\hline $05 \ldots$ & 1420 & 2.8 & 300 & -- & -- & 1 & .01 & -- \\
\hline $08 \ldots$ & 1340 & 2.8 & 304 & 16.0 & 16.5 & 1 & .01 & -- \\
\hline
\end{tabular}


Appendix 2. Instantaneous suspended-sediment and associated data at three continuous-record and four partial-record sediment stations in the Housatonic River Basin, western Massachusetts, March 1994 through April 1996-Continued

\begin{tabular}{|c|c|c|c|c|c|c|c|c|}
\hline DATE & TIME & $\begin{array}{c}\text { DISCHARGE, } \\
\text { INST. CUBIC } \\
\text { FEET PER } \\
\text { SECOND } \\
(00061)\end{array}$ & $\begin{array}{c}\text { SPECIFIC } \\
\text { CONDUC- } \\
\text { TANCE LAB } \\
\text { (US/CM) } \\
(90095)\end{array}$ & $\begin{array}{c}\text { TEMPERA- } \\
\text { TURE AIR } \\
\text { (DEG C) } \\
(00020)\end{array}$ & $\begin{array}{l}\text { TEMPERA- } \\
\text { TURE WATER } \\
\text { (DEG C) } \\
(00010)\end{array}$ & $\begin{array}{c}\text { SEDIMENT, } \\
\text { SUSPENDED } \\
\text { (MG/L) } \\
(\mathbf{8 0 1 5 4 )}\end{array}$ & $\begin{array}{c}\text { SEDIMENT, } \\
\text { DISCHARGE, } \\
\text { SUSPENDED } \\
\text { (T/DAY) } \\
(\mathbf{8 0 1 5 5 )}\end{array}$ & $\begin{array}{l}\text { SED. SUSP. } \\
\text { SIEVE DIAM. } \\
\text { \% FINER THAN } \\
.062 \text { MM } \\
(70331)\end{array}$ \\
\hline \multicolumn{9}{|c|}{$\begin{array}{l}\text { 01198000 - GREEN RIVER NEAR GREAT BARRINGTON, MA-Continued } \\
\text { WATER-QUALITY DATA, WATER YEAR OCTOBER } 1994 \text { TO SEPTEMBER 1995-Continued }\end{array}$} \\
\hline \multicolumn{9}{|c|}{ SEP-Continued } \\
\hline $10 \ldots$ & 1800 & 3.0 & 287 & 16.0 & 17.0 & 1 & 0.01 & -- \\
\hline $13 \ldots$ & 1630 & 3.5 & 293 & 19.0 & 16.0 & 1 & .01 & -- \\
\hline $21 \ldots$ & 1300 & 3.5 & 303 & 18.5 & 15.5 & 1 & .01 & -- \\
\hline $23 \ldots$ & 1150 & 5.6 & 300 & 11.5 & 14.5 & 2 & .03 & -- \\
\hline $25 \ldots$ & 1200 & 4.0 & 286 & 15.0 & 14.5 & 1 & .01 & -- \\
\hline $28 \ldots$ & 1520 & 3.7 & 302 & 19.0 & 17.5 & 2 & .02 & -- \\
\hline
\end{tabular}

\begin{tabular}{|c|c|c|c|c|c|c|c|c|}
\hline \multicolumn{9}{|c|}{ WATER-QUALITY DATA, WATER YEAR OCTOBER 1995 TO SEPTEMBER 1996} \\
\hline \multicolumn{9}{|l|}{ OCT } \\
\hline $02 \ldots$ & 1610 & 3.7 & 294 & 24.0 & 17.0 & 1 & 0.01 & -- \\
\hline $05 \ldots$ & 1500 & 4.8 & 303 & 16.5 & 14.5 & 1 & .01 & -- \\
\hline $05 \ldots$ & 2135 & 16 & 274 & -- & 14.5 & 7 & .30 & -- \\
\hline $05 \ldots$ & 2140 & 16 & 267 & -- & 14.5 & 6 & .26 & -- \\
\hline $06 \ldots$ & 0705 & 36 & 273 & -- & 13.5 & 26 & 2.5 & -- \\
\hline $06 \ldots$ & 0710 & 36 & 276 & -- & 13.5 & 24 & 2.3 & -- \\
\hline $06 \ldots$ & 0905 & 38 & 288 & -- & 14.0 & 13 & 1.3 & -- \\
\hline $06 \ldots$ & 0930 & 38 & 288 & 12.5 & 13.5 & 15 & 1.5 & -- \\
\hline $06 \ldots$ & 1352 & 77 & 268 & -- & 14.0 & 34 & 7.1 & -- \\
\hline $06 \ldots$ & 1358 & 78 & 255 & -- & 14.0 & 22 & 4.6 & -- \\
\hline $06 \ldots$ & 1605 & 79 & 222 & -- & 14.5 & 10 & 2.1 & -- \\
\hline $08 \ldots$ & 1235 & 21 & 263 & 13.5 & 13.5 & 2 & .11 & -- \\
\hline $11 \ldots$ & 1540 & 13 & 265 & 22.5 & 15.5 & 2 & .07 & -- \\
\hline $15 \ldots$ & 1120 & 26 & 286 & 12.0 & 13.5 & 5 & .35 & -- \\
\hline $20 \ldots$ & 1500 & 17 & 262 & 15.5 & 13.0 & 2 & .09 & -- \\
\hline $21 \ldots$ & 1525 & 26 & 246 & 19.0 & 15.0 & 3 & .21 & -- \\
\hline $22 \ldots$ & 0102 & 1080 & 93 & -- & 12.0 & 217 & 633 & 72 \\
\hline $22 \ldots$ & 0108 & 1080 & 92 & -- & 12.0 & 244 & 712 & 60 \\
\hline $22 \ldots$ & 0111 & 1080 & 90 & -- & 12.0 & 292 & 851 & -- \\
\hline $22 \ldots$ & 0314 & 1020 & 99 & -- & 11.5 & 118 & 325 & 61 \\
\hline $22 \ldots$ & 0316 & 1020 & 97 & -- & 11.5 & 115 & 317 & 61 \\
\hline $22 \ldots$ & 0320 & 1020 & 101 & -- & 11.5 & 111 & 306 & -- \\
\hline $22 \ldots$ & 0833 & 483 & 120 & -- & 10.5 & 37 & 48 & -- \\
\hline \multicolumn{9}{|l|}{ OCT } \\
\hline $22 \ldots$ & 0836 & 483 & 117 & -- & 10.5 & 36 & 47 & -- \\
\hline $22 \ldots$ & 1251 & 348 & 128 & -- & 12.0 & 29 & 27 & 44 \\
\hline $22 \ldots$ & 1255 & 348 & 124 & -- & 12.0 & 34 & 32 & 49 \\
\hline $22 \ldots$ & 1612 & 298 & 133 & -- & 13.0 & 13 & 10 & -- \\
\hline $23 \ldots$ & 1022 & 172 & 153 & -- & 10.0 & 4 & 1.9 & -- \\
\hline $26 \ldots$ & 1044 & 87 & 178 & -- & 10.0 & 3 & .70 & -- \\
\hline $28 \ldots$ & 0710 & 154 & 172 & -- & 13.0 & 18 & 7.5 & -- \\
\hline $28 \ldots$ & 1032 & 253 & 171 & -- & 13.0 & 54 & 37 & -- \\
\hline $28 \ldots$ & 1037 & 257 & 174 & -- & 13.0 & 37 & 26 & -- \\
\hline $28 \ldots$ & 1526 & 600 & 122 & -- & 13.0 & 62 & 100 & -- \\
\hline $28 \ldots$ & 1530 & 600 & 116 & -- & 13.0 & 46 & 75 & 74 \\
\hline $28 \ldots$ & 2210 & 403 & 134 & -- & 11.5 & 23 & 25 & -- \\
\hline $29 \ldots$ & 0812 & 265 & 143 & -- & 9.5 & 11 & 7.9 & -- \\
\hline $29 \ldots$ & 1400 & 231 & 148 & 9.5 & 11.0 & 6 & 3.7 & -- \\
\hline
\end{tabular}


Appendix 2. Instantaneous suspended-sediment and associated data at three continuous-record and four partial-record sediment stations in the Housatonic River Basin, western Massachusetts, March 1994 through April 1996—Continued

\begin{tabular}{|c|c|c|c|c|c|c|c|c|}
\hline DATE & TIME & $\begin{array}{c}\text { DISCHARGE, } \\
\text { INST. CUBIC } \\
\text { FEET PER } \\
\text { SECOND } \\
(00061)\end{array}$ & $\begin{array}{c}\text { SPECIFIC } \\
\text { CONDUC- } \\
\text { TANCE LAB } \\
(\text { US/CM) } \\
(90095)\end{array}$ & $\begin{array}{c}\text { TEMPERA- } \\
\text { TURE AIR } \\
\text { (DEG C) } \\
(00020)\end{array}$ & $\begin{array}{l}\text { TEMPERA- } \\
\text { TURE WATER } \\
\text { (DEG C) } \\
(00010)\end{array}$ & $\begin{array}{c}\text { SEDIMENT, } \\
\text { SUSPENDED } \\
\text { (MG/L) } \\
(\mathbf{8 0 1 5 4 )}\end{array}$ & $\begin{array}{c}\text { SEDIMENT, } \\
\text { DISCHARGE, } \\
\text { SUSPENDED } \\
\text { (T/DAY) } \\
(\mathbf{8 0 1 5 5 )}\end{array}$ & $\begin{array}{l}\text { SED. SUSP. } \\
\text { SIEVE DIAM. } \\
\text { \% FINER THAN } \\
.062 \text { MM } \\
(70331)\end{array}$ \\
\hline
\end{tabular}

01198000 - GREEN RIVER NEAR GREAT BARRINGTON, MA-Continued

WATER-QUALITY DATA, WATER YEAR OCTOBER 1995 TO SEPTEMBER 1996-Continued

\begin{tabular}{|c|c|c|c|c|c|c|c|c|}
\hline \multicolumn{9}{|l|}{ NOV } \\
\hline $02 \ldots$ & 1445 & 168 & 179 & 11.0 & 10.0 & 8 & 3.6 & -- \\
\hline $07 \ldots$ & 1615 & 91 & 188 & -- & 7.5 & 4 & .98 & -- \\
\hline $08 \ldots$ & 0710 & 152 & 162 & -- & 7.0 & 7 & 2.9 & -- \\
\hline $11 \ldots$ & 1145 & 91 & 185 & 13.5 & 8.5 & 3 & .73 & -- \\
\hline $12 \ldots$ & 0819 & 1480 & 96 & -- & 7.0 & 414 & 1650 & -- \\
\hline $12 \ldots$ & 0820 & 1480 & 96 & -- & 7.0 & 358 & 1430 & 74 \\
\hline $12 \ldots$ & 0824 & 1480 & 88 & -- & 7.0 & 444 & 1770 & 62 \\
\hline $12 \ldots$ & 1015 & 2020 & -- & 1.0 & 6.5 & 211 & 1150 & 64 \\
\hline $12 \ldots$ & 1020 & 2020 & 87 & 1.0 & 6.5 & 189 & 1030 & 70 \\
\hline $12 \ldots$ & 1215 & 1660 & 103 & -- & -- & 93 & 417 & -- \\
\hline $12 \ldots$ & 1220 & 1660 & 101 & -- & -- & 88 & 394 & 55 \\
\hline $12 \ldots$ & 1248 & 1550 & 100 & -- & 6.0 & 143 & 598 & 47 \\
\hline $12 \ldots$ & 1252 & 1510 & 102 & -- & 6.0 & 109 & 444 & 59 \\
\hline $12 \ldots$ & 1308 & 1480 & 106 & -- & 6.0 & 90 & 360 & 58 \\
\hline $12 \ldots$ & 1606 & 989 & 115 & -- & 5.0 & 56 & 150 & 80 \\
\hline $12 \ldots$ & 1609 & 989 & 113 & -- & 5.0 & 75 & 200 & -- \\
\hline $13 \ldots$ & 1210 & 425 & 144 & 2.0 & 6.0 & 20 & 23 & -- \\
\hline $13 \ldots$ & 1635 & 403 & 147 & .0 & 6.0 & 18 & 20 & -- \\
\hline $15 \ldots$ & 0835 & 494 & 146 & -- & 6.5 & 18 & 24 & -- \\
\hline $15 \ldots$ & 1126 & 487 & 141 & -- & 6.5 & 18 & 24 & -- \\
\hline $18 \ldots$ & 1545 & 216 & 165 & 1.0 & 5.5 & 2 & 1.2 & -- \\
\hline $20 \ldots$ & 1415 & 182 & 176 & 4.0 & 6.0 & 1 & .49 & -- \\
\hline $27 \ldots$ & 1525 & 91 & 195 & 7.5 & 6.0 & 4 & .98 & -- \\
\hline $30 \ldots$ & 1453 & 76 & 205 & -1.0 & 4.0 & 1 & .21 & -- \\
\hline \multicolumn{9}{|l|}{ DEC } \\
\hline $12 \ldots$ & 1415 & 56 & 219 & -6.0 & 1.5 & 2 & .30 & -- \\
\hline $16 \ldots$ & 1455 & 48 & 216 & 1.0 & 4.0 & 10 & 1.3 & -- \\
\hline $29 \ldots$ & 1550 & 36 & 227 & -.5 & 2.5 & 4 & .39 & -- \\
\hline \multicolumn{9}{|l|}{ JAN } \\
\hline $18 \ldots$ & 1009 & 42 & 217 & -- & 3.0 & 7 & .79 & -- \\
\hline $19 \ldots$ & 1535 & 773 & 161 & -- & 3.0 & 406 & 847 & -- \\
\hline $19 \ldots$ & 1539 & 835 & 159 & -- & 3.0 & 380 & 857 & -- \\
\hline $19 \ldots$ & 1542 & 835 & 158 & -- & 3.0 & 372 & 839 & 58 \\
\hline $19 \ldots$ & 1720 & 1280 & 135 & -- & 3.0 & 505 & 1750 & 50 \\
\hline $19 \ldots$ & 1733 & 1380 & 132 & -- & 3.0 & 513 & 1910 & -- \\
\hline $19 \ldots$ & 1736 & 1380 & 131 & -- & 3.0 & 483 & 1800 & 64 \\
\hline $19 \ldots$ & 1743 & 1480 & 125 & -- & 3.0 & 531 & 2120 & -- \\
\hline $19 \ldots$ & 2220 & 4370 & 100 & -- & .0 & 309 & 3650 & 86 \\
\hline $19 \ldots$ & 2225 & 4720 & 97 & -- & .0 & 315 & 4010 & -- \\
\hline $20 \ldots$ & 0025 & 6270 & 89 & -- & .0 & 162 & 2740 & -- \\
\hline $20 \ldots$ & 0035 & 6270 & 94 & -- & .0 & 150 & 2540 & 91 \\
\hline $20 \ldots$ & 0050 & 6420 & 93 & -- & .0 & 138 & 2390 & 93 \\
\hline $20 \ldots$ & 0840 & 2170 & 115 & -- & -.5 & 195 & 1140 & -- \\
\hline $20 \ldots$ & 0857 & 2170 & 115 & -- & .0 & 188 & 1100 & 64 \\
\hline $20 \ldots$ & 0902 & 2170 & 115 & -- & .0 & 199 & 1170 & -- \\
\hline $20 \ldots$ & 1417 & 1320 & 130 & -- & 1.0 & 181 & 645 & 59 \\
\hline $20 \ldots$ & 1425 & 1320 & 129 & -- & 1.0 & 165 & 588 & -- \\
\hline $21 \ldots$ & 0828 & 664 & 150 & -- & .0 & 76 & 136 & -- \\
\hline $21 \ldots$ & 0831 & 664 & 154 & -- & .0 & 63 & 113 & 50 \\
\hline
\end{tabular}


Appendix 2. Instantaneous suspended-sediment and associated data at three continuous-record and four partial-record sediment stations in the Housatonic River Basin, western Massachusetts, March 1994 through April 1996-Continued

\begin{tabular}{|c|c|c|c|c|c|c|c|c|}
\hline DATE & TIME & $\begin{array}{c}\text { DISCHARGE, } \\
\text { INST. CUBIC } \\
\text { FEET PER } \\
\text { SECOND } \\
(00061)\end{array}$ & $\begin{array}{c}\text { SPECIFIC } \\
\text { CONDUC- } \\
\text { TANCE LAB } \\
\text { (US/CM) } \\
(90095)\end{array}$ & $\begin{array}{c}\text { TEMPERA- } \\
\text { TURE AIR } \\
\text { (DEG C) } \\
\text { (00020) }\end{array}$ & $\begin{array}{l}\text { TEMPERA- } \\
\text { TURE WATER } \\
\text { (DEG C) } \\
(00010)\end{array}$ & $\begin{array}{c}\text { SEDIMENT, } \\
\text { SUSPENDED } \\
\text { (MG/L) } \\
(\mathbf{8 0 1 5 4 )}\end{array}$ & $\begin{array}{c}\text { SEDIMENT, } \\
\text { DISCHARGE, } \\
\text { SUSPENDED } \\
(\text { T/DAY) } \\
(\mathbf{8 0 1 5 5 )}\end{array}$ & $\begin{array}{l}\text { SED. SUSP. } \\
\text { SIEVE DIAM. } \\
\text { \% FINER THAN } \\
.062 \text { MM } \\
(\mathbf{7 0 3 3 1})\end{array}$ \\
\hline
\end{tabular}

01198000 - GREEN RIVER NEAR GREAT BARRINGTON, MA-Continued

WATER-QUALITY DATA, WATER YEAR OCTOBER 1995 TO SEPTEMBER 1996—Continued

\begin{tabular}{|c|c|c|c|c|c|c|c|c|}
\hline \multicolumn{9}{|c|}{ JAN_Continued } \\
\hline $22 \ldots$ & 1158 & 440 & 163 & -- & 2.5 & 17 & 20 & -- \\
\hline $22 \ldots$ & 1200 & 440 & 162 & -- & 2.5 & 19 & 23 & -- \\
\hline $24 \ldots$ & 1543 & 504 & 172 & -- & 4.5 & 71 & 97 & -- \\
\hline $24 \ldots$ & 1548 & 530 & 178 & -- & 4.5 & 92 & 132 & 46 \\
\hline $24 \ldots$ & 1925 & 900 & 143 & -- & 3.5 & 253 & 615 & -- \\
\hline $24 \ldots$ & 1927 & 900 & 147 & -- & 3.5 & 183 & 445 & 70 \\
\hline $25 \ldots$ & 0750 & 935 & 130 & -- & .5 & 68 & 172 & -- \\
\hline $25 \ldots$ & 0754 & 935 & 134 & -- & .5 & 66 & 167 & 69 \\
\hline $25 \ldots$ & 1554 & 660 & 137 & -- & 1.0 & 38 & 68 & 70 \\
\hline $25 \ldots$ & 1555 & 660 & 142 & -- & 1.0 & 54 & 96 & -- \\
\hline $26 \ldots$ & 1515 & 414 & 163 & 1.5 & 2.0 & 25 & 28 & -- \\
\hline $27 \ldots$ & 1515 & 1290 & 130 & 9.0 & 3.0 & 345 & 1200 & 42 \\
\hline $27 \ldots$ & 1520 & 1290 & 140 & 9.0 & 3.0 & 362 & 1260 & -- \\
\hline $28 \ldots$ & 0819 & 1040 & 127 & -- & .5 & 89 & 250 & -- \\
\hline $28 \ldots$ & 0830 & 1040 & 131 & -- & .5 & 77 & 216 & 66 \\
\hline $28 \ldots$ & 0832 & 1040 & 131 & -- & .5 & 160 & 449 & -- \\
\hline $28 \ldots$ & 1424 & 853 & 141 & -- & 1.5 & 65 & 150 & 57 \\
\hline $28 \ldots$ & 1428 & 853 & 137 & -- & 1.5 & 80 & 184 & -- \\
\hline $29 \ldots$ & 1145 & 512 & 154 & -- & 1.5 & 35 & 48 & -- \\
\hline \multicolumn{9}{|l|}{ FEB } \\
\hline $21 \ldots$ & 1106 & 130 & 197 & -- & 3.0 & 21 & 7.4 & -- \\
\hline $21 \ldots$ & 1109 & 130 & 199 & -- & 3.0 & 29 & 10 & -- \\
\hline $21 \ldots$ & 1802 & 226 & 185 & -- & 3.0 & 66 & 40 & -- \\
\hline $21 \ldots$ & 1805 & 230 & 183 & -- & 3.0 & 72 & 45 & -- \\
\hline $22 \ldots$ & 1159 & 530 & 132 & -- & 3.0 & 202 & 289 & -- \\
\hline $22 \ldots$ & 1200 & 530 & 132 & -- & 3.0 & 218 & 312 & -- \\
\hline $22 \ldots$ & 1503 & 620 & 118 & -- & 3.0 & 170 & 285 & -- \\
\hline $22 \ldots$ & 1510 & 620 & 117 & -- & 3.0 & 155 & 259 & -- \\
\hline $22 \ldots$ & 1759 & 578 & 121 & -- & 2.5 & 129 & 201 & -- \\
\hline $22 \ldots$ & 1801 & 578 & 120 & -- & 2.5 & 112 & 175 & -- \\
\hline $23 \ldots$ & 0854 & 350 & 133 & -- & 3.0 & 28 & 26 & -- \\
\hline $23 \ldots$ & 1533 & 338 & 142 & -- & 4.0 & 18 & 16 & -- \\
\hline $24 \ldots$ & 1505 & 383 & 135 & 7.5 & 3.5 & 55 & 57 & -- \\
\hline $24 \ldots$ & 1510 & 383 & 136 & 7.5 & 3.5 & 22 & 23 & -- \\
\hline $26 \ldots$ & 1300 & 242 & 147 & 6.5 & 4.0 & 16 & 10 & -- \\
\hline $27 \ldots$ & 1219 & 210 & 151 & -- & 4.5 & 17 & 9.6 & -- \\
\hline \multicolumn{9}{|l|}{ MAR } \\
\hline $13 \ldots$ & 1455 & 83 & 196 & 13.0 & 5.5 & 10 & 2.2 & -- \\
\hline $20 \ldots$ & 0957 & 151 & 174 & -- & 4.0 & 17 & 6.9 & -- \\
\hline $20 \ldots$ & 1750 & 162 & 171 & -- & 4.5 & 12 & 5.2 & -- \\
\hline $26 \ldots$ & 1245 & 137 & 168 & 9.0 & 7.0 & 5 & 1.8 & -- \\
\hline $29 \ldots$ & 1325 & 103 & 176 & 8.5 & 6.0 & 2 & .56 & -- \\
\hline \multicolumn{9}{|l|}{ APR } \\
\hline $01 \ldots$ & 1155 & 87 & 184 & -- & 6.0 & 1 & .23 & -- \\
\hline $01 \ldots$ & 1156 & 87 & 183 & -- & 6.0 & 1 & .23 & -- \\
\hline $01 \ldots$ & 1200 & 87 & 189 & -- & 6.0 & 1 & .23 & -- \\
\hline $01 \ldots$ & 1202 & 87 & 189 & -- & 6.0 & 1 & .23 & $\ldots$ \\
\hline
\end{tabular}


Appendix 2. Instantaneous suspended-sediment and associated data at three continuous-record and four partial-record sediment stations in the Housatonic River Basin, western Massachusetts, March 1994 through April 1996-Continued

\begin{tabular}{|c|c|c|c|c|c|c|c|c|}
\hline DATE & TIME & $\begin{array}{c}\text { DISCHARGE, } \\
\text { INST. CUBIC } \\
\text { FEET PER } \\
\text { SECOND } \\
(00061)\end{array}$ & $\begin{array}{c}\text { SPECIFIC } \\
\text { CONDUC- } \\
\text { TANCE LAB } \\
\text { (US/CM) } \\
(90095)\end{array}$ & $\begin{array}{c}\text { TEMPERA- } \\
\text { TURE AIR } \\
\text { (DEG C) } \\
(00020)\end{array}$ & $\begin{array}{l}\text { TEMPERA- } \\
\text { TURE WATER } \\
\text { (DEG C) } \\
(00010)\end{array}$ & $\begin{array}{c}\text { SEDIMENT, } \\
\text { SUSPENDED } \\
\text { (MG/L) } \\
(\mathbf{8 0 1 5 4 )}\end{array}$ & $\begin{array}{c}\text { SEDIMENT, } \\
\text { DISCHARGE, } \\
\text { SUSPENDED } \\
\text { (T/DAY) } \\
(80155)\end{array}$ & $\begin{array}{l}\text { SED. SUSP. } \\
\text { SIEVE DIAM. } \\
\text { \% FINER THAN } \\
.062 \text { MM } \\
(70331)\end{array}$ \\
\hline
\end{tabular}

$$
01198080 \text { - SCHENOB BROOK AT ROUTE } 7 \text { AT SHEFFIELD, MA }
$$

WATER-QUALITY DATA, WATER YEAR OCTOBER 1993 TO SEPTEMBER 1994

\begin{tabular}{|c|c|c|c|c|c|c|c|c|}
\hline \multicolumn{9}{|l|}{ MAR } \\
\hline $29 \ldots$ & 1525 & 480 & -- & 3.0 & 2.0 & 98 & 127 & -- \\
\hline \multicolumn{9}{|l|}{ APR } \\
\hline $07 \ldots$ & 1915 & 477 & -- & 3.0 & 5.0 & 4 & 5.2 & -- \\
\hline \multicolumn{9}{|l|}{ JUL } \\
\hline $15 \ldots$ & 1035 & 8.9 & 232 & -- & 23.0 & 8 & .20 & -- \\
\hline \multicolumn{9}{|l|}{ AUG } \\
\hline $04 \ldots$ & 1930 & 31 & 226 & 29.0 & 25.5 & 4 & .36 & -- \\
\hline $19 \ldots$ & 1135 & 91 & 232 & 22.5 & 20.5 & 8 & 2.0 & 90 \\
\hline \multicolumn{9}{|c|}{ WATER-QUALITY DATA, WATER YEAR OCTOBER 1994 TO SEPTEMBER 1995} \\
\hline \multicolumn{9}{|l|}{ NOV } \\
\hline $29 \ldots$ & 1746 & 198 & 245 & 4.0 & 2.5 & 34 & 18 & 45 \\
\hline \multicolumn{9}{|l|}{ MAR } \\
\hline $15 \ldots$ & 1238 & 181 & 224 & 18.0 & 6.5 & 4 & 2.0 & 92 \\
\hline
\end{tabular}

01198122 - IRONWORKS BROOK, ON EAST ROAD, AT SHEFFIELD, MA

WATER-QUALITY DATA, WATER YEAR OCTOBER 1993 TO SEPTEMBER 1994

\begin{tabular}{|c|c|c|c|c|c|c|c|c|}
\hline \multicolumn{9}{|l|}{ MAR } \\
\hline $31 \ldots$ & 1055 & 68 & -- & 4.5 & 2.0 & 21 & 3.9 & $\ldots$ \\
\hline \multicolumn{9}{|l|}{ JUL } \\
\hline $15 \ldots$ & 1210 & .73 & 153 & 20.0 & 19.0 & 7 & .01 & - \\
\hline \multicolumn{9}{|l|}{ AUG } \\
\hline $04 \ldots$ & 1750 & 11 & 130 & 32.0 & 25.5 & 4 & .12 & - \\
\hline \multicolumn{9}{|c|}{ WATER-QUALITY DATA, WATER YEAR OCTOBER 1994 TO SEPTEMBER 1995} \\
\hline \multicolumn{9}{|l|}{ NOV } \\
\hline $28 \ldots$ & 1650 & 36 & 130 & 13.5 & 3.0 & 106 & 10 & 32 \\
\hline \multicolumn{9}{|l|}{ MAR } \\
\hline $13 \ldots$ & 1838 & 52 & 91 & -- & 4.5 & 59 & 8.3 & 46 \\
\hline \multicolumn{9}{|l|}{ APR } \\
\hline $13 \ldots$ & 1130 & 42 & 90 & -- & 7.5 & 72 & 8.2 & 49 \\
\hline
\end{tabular}

WATER-QUALITY DATA, WATER YEAR OCTOBER 1995 TO SEPTEMBER 1996

\begin{tabular}{|c|c|c|c|c|c|c|c|c|}
\hline \multicolumn{9}{|l|}{ OCT } \\
\hline $05 \ldots$ & 1700 & 2.4 & 173 & -- & 14.5 & 15 & 0.10 & -- \\
\hline $05 \ldots$ & 2210 & 16 & 178 & -- & 14.5 & 54 & 2.3 & 51 \\
\hline $06 \ldots$ & 0735 & 26 & 167 & -- & 13.5 & 38 & 2.7 & 42 \\
\hline $06 \ldots$ & 1021 & 26 & 169 & -- & 13.5 & 25 & 1.8 & -- \\
\hline $06 \ldots$ & 1432 & 24 & 168 & -- & 14.5 & 12 & .78 & -- \\
\hline $06 \ldots$ & 1630 & 22 & 167 & -- & 15.0 & 8 & .48 & -- \\
\hline $22 \ldots$ & 0133 & 43 & 130 & -- & 12.5 & 33 & 3.8 & 51 \\
\hline $22 \ldots$ & 0340 & 44 & 132 & -- & 12.5 & 32 & 3.8 & 38 \\
\hline $22 \ldots$ & 0905 & 32 & 140 & -- & 10.5 & 13 & 1.1 & -- \\
\hline $22 \ldots$ & 1642 & 22 & 145 & -- & 13.0 & 8 & .48 & -- \\
\hline $26 \ldots$ & 1140 & 9.9 & 157 & -- & 10.0 & 3 & .08 & -- \\
\hline $28 \ldots$ & 0803 & 261 & 93 & -- & 13.5 & 930 & 655 & 54 \\
\hline $28 \ldots$ & 1122 & 193 & 92 & -- & 13.5 & 258 & 134 & 37 \\
\hline
\end{tabular}


Appendix 2. Instantaneous suspended-sediment and associated data at three continuous-record and four partial-record sediment stations in the Housatonic River Basin, western Massachusetts, March 1994 through April 1996-Continued

\begin{tabular}{|c|c|c|c|c|c|c|c|c|}
\hline DATE & TIME & $\begin{array}{c}\text { DISCHARGE, } \\
\text { INST. CUBIC } \\
\text { FEET PER } \\
\text { SECOND } \\
(00061)\end{array}$ & $\begin{array}{c}\text { SPECIFIC } \\
\text { CONDUC- } \\
\text { TANCE LAB } \\
\text { (US/CM) } \\
(90095)\end{array}$ & $\begin{array}{c}\text { TEMPERA- } \\
\text { TURE AIR } \\
\text { (DEG C) } \\
\text { (00020) }\end{array}$ & $\begin{array}{l}\text { TEMPERA- } \\
\text { TURE WATER } \\
\text { (DEG C) } \\
(00010)\end{array}$ & $\begin{array}{l}\text { SEDIMENT, } \\
\text { SUSPENDED } \\
\text { (MG/L) } \\
(\mathbf{8 0 1 5 4 )}\end{array}$ & $\begin{array}{c}\text { SEDIMENT, } \\
\text { DISCHARGE, } \\
\text { SUSPENDED } \\
\text { (T/DAY) } \\
(\mathbf{8 0 1 5 5 )}\end{array}$ & $\begin{array}{l}\text { SED. SUSP. } \\
\text { SIEVE DIAM. } \\
\text { \% FINER THAN } \\
.062 \text { MM } \\
(70331)\end{array}$ \\
\hline
\end{tabular}

WATER-QUALITY DATA, WATER YEAR OCTOBER 1995 TO SEPTEMBER 1996-Continued

\begin{tabular}{|c|c|c|c|c|c|c|c|c|}
\hline \multicolumn{9}{|c|}{ OCT-Continued } \\
\hline $28 \ldots$ & 1632 & 126 & 92 & -- & 14.0 & 56 & 19 & 59 \\
\hline $29 \ldots$ & 0838 & 48 & 125 & -- & 10.5 & 27 & 3.5 & -- \\
\hline \multicolumn{9}{|l|}{ NOV } \\
\hline $07 \ldots$ & 1650 & 15 & 137 & -- & 6.5 & 6 & .24 & -- \\
\hline $08 \ldots$ & 0743 & 19 & 126 & -- & 6.0 & 9 & .46 & -- \\
\hline $12 \ldots$ & 1010 & 121 & 89 & -- & 5.5 & 93 & 30 & 45 \\
\hline $12 \ldots$ & 1744 & 63 & 94 & -- & 5.0 & 27 & 4.6 & 36 \\
\hline $15 \ldots$ & 0905 & 67 & 100 & -- & 5.0 & 21 & 3.8 & 52 \\
\hline \multicolumn{9}{|l|}{ JAN } \\
\hline $19 \ldots$ & 1653 & 275 & 124 & -- & 1.0 & 1200 & 891 & -- \\
\hline $19 \ldots$ & 1657 & 275 & 124 & -- & 1.0 & 1360 & 1010 & -- \\
\hline $19 \ldots$ & 1923 & 402 & 91 & -- & .5 & 1320 & 1430 & -- \\
\hline $19 \ldots$ & 1925 & 402 & 92 & -- & .5 & 1400 & 1520 & -- \\
\hline $20 \ldots$ & 0005 & 268 & 72 & -- & -- & 319 & 231 & -- \\
\hline $20 \ldots$ & 0010 & 268 & 73 & -- & -- & 319 & 231 & -- \\
\hline $20 \ldots$ & 1145 & 121 & 80 & -- & .0 & 69 & 23 & -- \\
\hline $20 \ldots$ & 1150 & 121 & 79 & -- & .0 & 66 & 22 & -- \\
\hline $20 \ldots$ & 1602 & 102 & 89 & -- & .0 & 257 & 71 & -- \\
\hline $20 \ldots$ & 1608 & 102 & 96 & -- & .0 & 256 & 71 & 32 \\
\hline $21 \ldots$ & 1159 & 87 & 107 & -- & .0 & 26 & 6.1 & -- \\
\hline $21 \ldots$ & 1200 & 87 & 106 & -- & .0 & 31 & 7.3 & -- \\
\hline $24 \ldots$ & 1645 & 181 & 79 & -- & 2.0 & 628 & 307 & -- \\
\hline $24 \ldots$ & 1647 & 181 & 80 & -- & 2.0 & 639 & 312 & -- \\
\hline $25 \ldots$ & 0933 & 121 & 81 & -- & .0 & 85 & 28 & -- \\
\hline $25 \ldots$ & 0938 & 121 & 82 & -- & .0 & 76 & 25 & -- \\
\hline $28 \ldots$ & 0907 & 167 & 83 & -- & .0 & 82 & 37 & -- \\
\hline $28 \ldots$ & 0909 & 167 & 85 & -- & .0 & 92 & 41 & -- \\
\hline $28 \ldots$ & 1458 & 158 & 91 & -- & .5 & 137 & 58 & -- \\
\hline $28 \ldots$ & 1501 & 158 & 89 & -- & .5 & 124 & 53 & 17 \\
\hline $29 \ldots$ & 1226 & 85 & 97 & -- & .5 & 73 & 17 & 15 \\
\hline \multicolumn{9}{|l|}{ FEB } \\
\hline $22 \ldots$ & 1615 & 105 & 76 & -- & 1.5 & 285 & 81 & -- \\
\hline $22 \ldots$ & 1618 & 105 & 74 & -- & 1.5 & 256 & 73 & -- \\
\hline $23 \ldots$ & 1050 & 57 & 94 & -- & 2.0 & 42 & 6.5 & -- \\
\hline \multicolumn{9}{|l|}{ MAR } \\
\hline $20 \ldots$ & 1730 & 49 & 96 & -- & 4.0 & 24 & 3.2 & -- \\
\hline \multicolumn{9}{|l|}{ APR } \\
\hline $01 \ldots$ & 1320 & 18 & 108 & -- & 6.5 & 4 & .19 & -- \\
\hline $01 \ldots$ & 1325 & 18 & 111 & -- & 6.5 & 1 & .05 & -- \\
\hline $02 \ldots$ & 0759 & 36 & 108 & -- & 3.0 & 28 & 2.7 & -- \\
\hline $02 \ldots$ & 0801 & 36 & 105 & -- & 3.0 & 26 & 2.5 & -- \\
\hline $02 \ldots$ & 1516 & 38 & 104 & -- & 7.5 & 20 & 2.1 & -- \\
\hline $02 \ldots$ & 1519 & 38 & 101 & -- & 7.5 & 20 & 2.1 & -- \\
\hline \multicolumn{9}{|c|}{$\begin{array}{c}\text { 01198125 - HOUSATONIC RIVER NEAR ASHLEY FALLS, MA } \\
\text { WATER-QUALITY DATA, WATER YEAR OCTOBER } 1993 \text { TO SEPTEMBER } 1994\end{array}$} \\
\hline \multicolumn{9}{|l|}{ MAR } \\
\hline $25 \ldots$ & 1258 & 2820 & -- & -- & -- & 105 & 799 & -- \\
\hline $25 \ldots$ & 1313 & 2820 & -- & -- & -- & 84 & 640 & -- \\
\hline
\end{tabular}


Appendix 2. Instantaneous suspended-sediment and associated data at three continuous-record and four partial-record sediment stations in the Housatonic River Basin, western Massachusetts, March 1994 through April 1996-Continued

\begin{tabular}{|c|c|c|c|c|c|c|c|c|}
\hline DATE & TIME & $\begin{array}{c}\text { DISCHARGE, } \\
\text { INST. CUBIC } \\
\text { FEET PER } \\
\text { SECOND } \\
(00061)\end{array}$ & $\begin{array}{c}\text { SPECIFIC } \\
\text { CONDUC- } \\
\text { TANCE LAB } \\
\text { (US/CM) } \\
(90095)\end{array}$ & $\begin{array}{c}\text { TEMPERA- } \\
\text { TURE AIR } \\
\text { (DEG C) } \\
\text { (00020) }\end{array}$ & $\begin{array}{l}\text { TEMPERA- } \\
\text { TURE WATER } \\
\text { (DEG C) } \\
(00010)\end{array}$ & $\begin{array}{c}\text { SEDIMENT, } \\
\text { SUSPENDED } \\
\text { (MG/L) } \\
(\mathbf{8 0 1 5 4 )}\end{array}$ & $\begin{array}{c}\text { SEDIMENT, } \\
\text { DISCHARGE, } \\
\text { SUSPENDED } \\
(\text { T/DAY) } \\
(\mathbf{8 0 1 5 5 )}\end{array}$ & $\begin{array}{l}\text { SED. SUSP. } \\
\text { SIEVE DIAM. } \\
\text { \% FINER THAN } \\
.062 \text { MM } \\
(\mathbf{7 0 3 3 1})\end{array}$ \\
\hline
\end{tabular}

01198125 - HOUSATONIC RIVER NEAR ASHLEY FALLS, MA-Continued

WATER-QUALITY DATA, WATER YEAR OCTOBER 1993 TO SEPTEMBER 1994—Continued

\begin{tabular}{|c|c|c|c|c|c|c|c|c|}
\hline \multicolumn{9}{|c|}{ MAR_-Continued } \\
\hline $25 \ldots$ & 1355 & 2830 & -- & -- & -- & 90 & 688 & -- \\
\hline $28 \ldots$ & 1825 & 3140 & -- & 5.0 & 2.0 & 60 & 509 & -- \\
\hline $28 \ldots$ & 1830 & 3140 & -- & 5.0 & 2.0 & 70 & 593 & -- \\
\hline $29 \ldots$ & 1130 & 3360 & -- & 3.5 & 1.5 & 73 & 662 & -- \\
\hline $29 \ldots$ & 1140 & 3360 & -- & 3.5 & 1.5 & 74 & 671 & -- \\
\hline $30 \ldots$ & 1600 & 3310 & -- & 4.0 & 3.0 & 66 & 590 & -- \\
\hline \multicolumn{9}{|l|}{ APR } \\
\hline $05 \ldots$ & 1645 & 3970 & 188 & 16.5 & 6.0 & 69 & 740 & -- \\
\hline $05 \ldots$ & 1650 & 3970 & -- & 16.5 & 6.0 & 75 & 804 & 44 \\
\hline $06 \ldots$ & 1045 & 3970 & 185 & 9.0 & 6.0 & 54 & 579 & -- \\
\hline $07 \ldots$ & 1300 & 4220 & 178 & 5.5 & 5.0 & 57 & 649 & -- \\
\hline $07 \ldots$ & 1310 & 4220 & 181 & 5.5 & 5.0 & 62 & 706 & -- \\
\hline $07 \ldots$ & 1325 & 4220 & 179 & 5.5 & 5.0 & 45 & 513 & -- \\
\hline $07 \ldots$ & 1650 & 4300 & -- & 5.0 & 5.0 & 65 & 755 & 65 \\
\hline $07 \ldots$ & 1655 & 4300 & 179 & 5.0 & 5.0 & 59 & 685 & -- \\
\hline $08 \ldots$ & 0935 & 4770 & -- & 4.0 & 3.0 & 87 & 1120 & 47 \\
\hline $08 \ldots$ & 0940 & 4770 & 170 & 4.0 & 3.0 & 71 & 914 & -- \\
\hline $08 \ldots$ & 1455 & 4880 & 170 & 9.0 & 4.0 & 92 & 1210 & -- \\
\hline $08 \ldots$ & 1500 & 4880 & -- & 9.0 & 4.0 & 74 & 975 & 50 \\
\hline $08 \ldots$ & 1510 & 4880 & 168 & 9.0 & 4.0 & 57 & 751 & -- \\
\hline $08 \ldots$ & 1540 & 4880 & -- & 9.0 & 4.0 & 62 & 817 & 46 \\
\hline $14 \ldots$ & 1330 & 4790 & 163 & 14.5 & 6.5 & 55 & 711 & -- \\
\hline $14 \ldots$ & 1755 & 4970 & 166 & 20.0 & 7.5 & 47 & 631 & -- \\
\hline $14 \ldots$ & 1800 & 4970 & 170 & 20.0 & 7.5 & 48 & 644 & -- \\
\hline $15 \ldots$ & 0920 & 5320 & 161 & 12.0 & 7.0 & 73 & 1050 & -- \\
\hline $15 \ldots$ & 0925 & 5320 & -- & 12.0 & 7.0 & 56 & 804 & 52 \\
\hline \multicolumn{9}{|l|}{ MAY } \\
\hline $05 \ldots$ & 1710 & 1010 & 280 & 19.5 & 13.0 & 10 & 27 & -- \\
\hline $05 \ldots$ & 1715 & 1010 & 283 & 19.5 & 13.0 & 9 & 25 & -- \\
\hline $13 \ldots$ & 1445 & 1170 & 287 & 14.0 & 13.0 & 10 & 32 & -- \\
\hline $13 \ldots$ & 1450 & 1170 & 280 & 14.0 & 13.0 & 12 & 38 & -- \\
\hline $19 \ldots$ & 1345 & 1730 & 240 & 13.0 & 12.0 & 21 & 98 & -- \\
\hline $19 \ldots$ & 1350 & 1730 & 236 & 13.0 & 12.0 & 25 & 117 & -- \\
\hline $28 \ldots$ & 1530 & 748 & 301 & 18.0 & 16.0 & 7 & 14 & -- \\
\hline $28 \ldots$ & 1535 & 748 & 300 & 18.0 & 16.0 & 6 & 12 & 50 \\
\hline \multicolumn{9}{|l|}{ JUN } \\
\hline $02 \ldots$ & 1515 & 497 & 328 & 16.0 & 17.0 & 6 & 8.1 & -- \\
\hline $02 \ldots$ & 1520 & 497 & 323 & 16.0 & 17.0 & 8 & 11 & -- \\
\hline $10 \ldots$ & 1355 & 373 & 361 & 25.0 & 20.5 & 2 & 2.0 & -- \\
\hline $10 \ldots$ & 1400 & 373 & 361 & 25.0 & 20.5 & 1 & 1.0 & -- \\
\hline $15 \ldots$ & 1735 & 431 & 359 & 29.0 & 24.0 & 1 & 1.2 & -- \\
\hline $15 \ldots$ & 1745 & 431 & 352 & 29.0 & 24.0 & 6 & 7.0 & -- \\
\hline $22 \ldots$ & 1235 & 252 & 359 & 22.5 & 22.0 & 5 & 3.4 & -- \\
\hline $22 \ldots$ & 1240 & 252 & 370 & 22.5 & 22.0 & 3 & 2.0 & 100 \\
\hline $29 \ldots$ & 1235 & 229 & 360 & 24.0 & 21.5 & 4 & 2.5 & -- \\
\hline $29 \ldots$ & 1240 & 229 & 373 & 24.0 & 21.5 & 7 & 4.3 & -- \\
\hline \multicolumn{9}{|l|}{ JUL } \\
\hline $07 \ldots$ & 1050 & 189 & 344 & 30.0 & 25.5 & 6 & 3.1 & -- \\
\hline $07 \ldots$ & 1100 & 189 & 349 & 30.0 & 25.5 & 6 & 3.1 & -- \\
\hline
\end{tabular}


Appendix 2. Instantaneous suspended-sediment and associated data at three continuous-record and four partial-record sediment stations in the Housatonic River Basin, western Massachusetts, March 1994 through April 1996—Continued

\begin{tabular}{|c|c|c|c|c|c|c|c|c|}
\hline DATE & TIME & $\begin{array}{c}\text { DISCHARGE, } \\
\text { INST. CUBIC } \\
\text { FEET PER } \\
\text { SECOND } \\
(00061)\end{array}$ & $\begin{array}{c}\text { SPECIFIC } \\
\text { CONDUC- } \\
\text { TANCE LAB } \\
\text { (US/CM) } \\
(90095)\end{array}$ & $\begin{array}{c}\text { TEMPERA- } \\
\text { TURE AIR } \\
\text { (DEG C) } \\
(00020)\end{array}$ & $\begin{array}{l}\text { TEMPERA- } \\
\text { TURE WATER } \\
\text { (DEG C) } \\
(00010)\end{array}$ & $\begin{array}{c}\text { SEDIMENT, } \\
\text { SUSPENDED } \\
\text { (MG/L) } \\
(\mathbf{8 0 1 5 4 )}\end{array}$ & $\begin{array}{c}\text { SEDIMENT, } \\
\text { DISCHARGE, } \\
\text { SUSPENDED } \\
\text { (T/DAY) } \\
(\mathbf{8 0 1 5 5 )}\end{array}$ & $\begin{array}{l}\text { SED. SUSP. } \\
\text { SIEVE DIAM. } \\
\text { \% FINER THAN } \\
.062 \text { MM } \\
(70331)\end{array}$ \\
\hline \multicolumn{9}{|c|}{$\begin{array}{l}\text { 01198125 - HOUSATONIC RIVER NEAR ASHLEY FALLS, MA-Continued } \\
\text { WATER-QUALITY DATA, WATER YEAR OCTOBER } 1993 \text { TO SEPTEMBER 1994-Continued }\end{array}$} \\
\hline \multicolumn{9}{|c|}{ JUL-Continued } \\
\hline $15 \ldots$ & 1415 & 152 & 388 & 25.0 & 23.5 & 2 & 0.82 & -- \\
\hline $15 \ldots$ & 1425 & 152 & 390 & 25.0 & 23.5 & 3 & 1.2 & -- \\
\hline $21 \ldots$ & 1920 & 216 & 412 & 29.0 & 27.5 & 1 & .58 & -- \\
\hline $21 \ldots$ & 1925 & 216 & 412 & 29.0 & 27.5 & ${ }^{1} 0$ & .17 & -- \\
\hline $22 \ldots$ & 1330 & 262 & 435 & 30.5 & 28.0 & 4 & 2.8 & -- \\
\hline $22 \ldots$ & 1340 & 262 & 427 & 30.5 & 28.0 & 1 & .70 & -- \\
\hline $22 \ldots$ & 1405 & 262 & 437 & 30.5 & 28.0 & 2 & 1.4 & -- \\
\hline $27 \ldots$ & 1710 & 644 & 247 & 29.5 & 24.0 & 16 & 28 & -- \\
\hline $27 \ldots$ & 1715 & 644 & 242 & 29.5 & 24.0 & 8 & 14 & -- \\
\hline \multicolumn{9}{|l|}{ AUG } \\
\hline $04 \ldots$ & 1555 & 295 & 296 & 31.0 & 25.0 & 6 & 4.8 & -- \\
\hline $04 \ldots$ & 1600 & 295 & 302 & 31.0 & 25.0 & 5 & 4.0 & -- \\
\hline $11 \ldots$ & 1910 & 168 & 368 & 22.0 & 21.0 & 2 & .91 & -- \\
\hline $11 \ldots$ & 1915 & 168 & 385 & 22.0 & 21.0 & 1 & .45 & -- \\
\hline $17 \ldots$ & 1100 & 224 & 408 & 20.0 & 20.0 & 12 & 7.3 & -- \\
\hline $17 \ldots$ & 1105 & 224 & 412 & 20.0 & 20.0 & 19 & 11 & -- \\
\hline $19 \ldots$ & 0845 & 598 & 328 & 19.5 & 19.5 & 23 & 37 & 84 \\
\hline $19 \ldots$ & 0850 & 598 & 325 & 19.5 & 19.5 & 34 & 55 & -- \\
\hline $23 \ldots$ & 1615 & 1280 & 298 & 21.0 & 19.5 & 44 & 152 & 70 \\
\hline $23 \ldots$ & 1625 & 1280 & 287 & 21.0 & 19.5 & 92 & 318 & -- \\
\hline $23 \ldots$ & 1915 & 1270 & 284 & 18.0 & 19.5 & 36 & 123 & 56 \\
\hline $24 \ldots$ & 1500 & 983 & 266 & 27.0 & 19.5 & 30 & 80 & 61 \\
\hline $24 \ldots$ & 1505 & 983 & 258 & 27.0 & 19.5 & 28 & 74 & 46 \\
\hline $24 \ldots$ & 1525 & 983 & 257 & 27.0 & 19.5 & 12 & 32 & -- \\
\hline \multicolumn{9}{|l|}{ SEP } \\
\hline $01 \ldots$ & 1840 & 306 & 339 & 17.5 & 19.0 & 13 & 11 & -- \\
\hline $01 \ldots$ & 1845 & 306 & 336 & 17.5 & 19.0 & 10 & 8.3 & -- \\
\hline $08 \ldots$ & 1150 & 182 & 384 & 15.0 & 18.0 & 5 & 2.5 & -- \\
\hline $08 \ldots$ & 1210 & 182 & 340 & 15.0 & 18.0 & 5 & 2.5 & -- \\
\hline $08 \ldots$ & 1240 & 182 & 389 & 15.0 & 18.0 & 8 & 3.9 & -- \\
\hline $15 \ldots$ & 1525 & 178 & 403 & 23.0 & 20.5 & 7 & 3.4 & -- \\
\hline $15 \ldots$ & 1530 & 178 & 403 & 23.0 & 20.5 & 9 & 4.3 & -- \\
\hline $22 \ldots$ & 1130 & 151 & 400 & -- & 13.0 & 6 & 2.4 & -- \\
\hline $22 \ldots$ & 1135 & 151 & 387 & -- & 13.0 & 10 & 4.1 & -- \\
\hline $25 \ldots$ & 1425 & 275 & 413 & 24.0 & 18.0 & 4 & 3.0 & -- \\
\hline $25 \ldots$ & 1430 & 275 & 415 & 24.0 & 18.0 & 3 & 2.2 & -- \\
\hline $28 \ldots$ & 1220 & 813 & 340 & 19.0 & 17.5 & 45 & 99 & -- \\
\hline $28 \ldots$ & 1225 & 816 & 326 & 19.0 & 17.5 & 18 & 40 & 86 \\
\hline $28 \ldots$ & 1528 & 897 & 305 & 20.5 & 17.0 & 62 & 150 & 64 \\
\hline $28 \ldots$ & 1535 & 903 & 304 & -- & 17.0 & 58 & 141 & 83 \\
\hline $29 \ldots$ & 1235 & 1140 & 313 & 14.0 & 16.0 & 44 & 135 & 94 \\
\hline $29 \ldots$ & 1245 & 1140 & 317 & 14.0 & 16.0 & 54 & 166 & 58 \\
\hline $30 \ldots$ & 1845 & 820 & 269 & 12.0 & 14.5 & 21 & 46 & -- \\
\hline $30 \ldots$ & 1850 & 820 & 265 & 12.0 & 14.5 & 16 & 35 & 83 \\
\hline
\end{tabular}

WATER-QUALITY DATA, WATER YEAR OCTOBER 1994 TO SEPTEMBER 1995

OCT

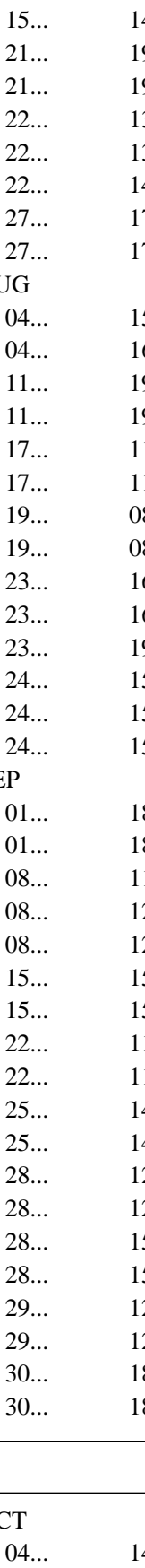

$04 \ldots$

1420

1430
449

447
312

310
12.0

12.0
11.5

11.5

\section{1 \\ 7.2}


Appendix 2. Instantaneous suspended-sediment and associated data at three continuous-record and four partial-record sediment stations in the Housatonic River Basin, western Massachusetts, March 1994 through April 1996-Continued

\begin{tabular}{|c|c|c|c|c|c|c|c|c|}
\hline DATE & TIME & $\begin{array}{c}\text { DISCHARGE, } \\
\text { INST. CUBIC } \\
\text { FEET PER } \\
\text { SECOND } \\
(00061)\end{array}$ & $\begin{array}{c}\text { SPECIFIC } \\
\text { CONDUC- } \\
\text { TANCE LAB } \\
\text { (US/CM) } \\
(90095)\end{array}$ & $\begin{array}{c}\text { TEMPERA- } \\
\text { TURE AIR } \\
\text { (DEG C) } \\
\text { (00020) }\end{array}$ & $\begin{array}{l}\text { TEMPERA- } \\
\text { TURE WATER } \\
\text { (DEG C) } \\
(00010)\end{array}$ & $\begin{array}{c}\text { SEDIMENT, } \\
\text { SUSPENDED } \\
\text { (MG/L) } \\
(\mathbf{8 0 1 5 4 )}\end{array}$ & $\begin{array}{c}\text { SEDIMENT, } \\
\text { DISCHARGE, } \\
\text { SUSPENDED } \\
(\text { T/DAY) } \\
(\mathbf{8 0 1 5 5 )}\end{array}$ & $\begin{array}{l}\text { SED. SUSP. } \\
\text { SIEVE DIAM. } \\
\text { \% FINER THAN } \\
.062 \text { MM } \\
(\mathbf{7 0 3 3 1})\end{array}$ \\
\hline
\end{tabular}

01198125 - HOUSATONIC RIVER NEAR ASHLEY FALLS, MA-Continued

WATER-QUALITY DATA, WATER YEAR OCTOBER 1994 TO SEPTEMBER 1995—Continued

\begin{tabular}{|c|c|c|c|c|c|c|c|c|}
\hline \multicolumn{9}{|c|}{ OCT-Continued } \\
\hline $07 \ldots$ & 1105 & 400 & 331 & 9.0 & 10.5 & 9 & 9.7 & -- \\
\hline $07 \ldots$ & 1115 & 400 & 329 & 9.0 & 10.5 & 6 & 6.5 & -- \\
\hline $07 \ldots$ & 1550 & 403 & 331 & -- & 12.5 & 6 & 6.5 & -- \\
\hline $11 \ldots$ & 1430 & 413 & 324 & 10.5 & 11.0 & 4 & 4.5 & -- \\
\hline $11 \ldots$ & 1440 & 413 & 329 & 10.5 & 11.0 & 1 & 1.1 & -- \\
\hline $15 \ldots$ & 1400 & 312 & 327 & 14.0 & 11.5 & 4 & 3.4 & -- \\
\hline $15 \ldots$ & 1410 & 312 & 331 & 14.0 & 11.0 & 3 & 2.5 & -- \\
\hline $19 \ldots$ & 1220 & 290 & 365 & 19.5 & 11.5 & 1 & .78 & -- \\
\hline $19 \ldots$ & 1230 & 290 & 360 & 19.5 & 12.0 & 1 & .78 & -- \\
\hline $24 \ldots$ & 1055 & 366 & 350 & 17.5 & 11.5 & 1 & .99 & -- \\
\hline $27 \ldots$ & 1435 & 371 & 340 & 10.5 & 10.0 & 4 & 4.0 & -- \\
\hline $30 \ldots$ & 1530 & 319 & 353 & 18.5 & 10.0 & 1 & .86 & -- \\
\hline \multicolumn{9}{|l|}{ NOV } \\
\hline $03 \ldots$ & 1530 & 398 & 350 & 16.0 & 10.0 & 1 & 1.1 & -- \\
\hline $08 \ldots$ & 1355 & 324 & 342 & 15.5 & 9.5 & 5 & 4.4 & -- \\
\hline $12 \ldots$ & 1030 & 310 & 367 & 6.0 & 6.0 & 3 & 2.5 & -- \\
\hline $16 \ldots$ & 1110 & 290 & 372 & 9.0 & 7.5 & 2 & 1.6 & -- \\
\hline $20 \ldots$ & 1430 & 275 & 368 & 7.5 & 7.0 & 26 & 19 & -- \\
\hline $28 \ldots$ & 1350 & 455 & 302 & 10.5 & 2.5 & 11 & 14 & -- \\
\hline $29 \ldots$ & 1600 & 1050 & 287 & 8.5 & 6.0 & 36 & 102 & 98 \\
\hline $30 \ldots$ & 1555 & 1060 & 266 & 5.0 & 6.0 & 17 & 49 & -- \\
\hline \multicolumn{9}{|l|}{ DEC } \\
\hline $02 \ldots$ & 1300 & 731 & 266 & 9.5 & 6.0 & 12 & 24 & -- \\
\hline $06 \ldots$ & 0805 & 1450 & 252 & 9.0 & 5.5 & 63 & 247 & 91 \\
\hline $06 \ldots$ & 1330 & 1590 & 254 & 13.0 & 6.0 & 46 & 197 & 97 \\
\hline $07 \ldots$ & 1030 & 1730 & 237 & 4.0 & 5.5 & 47 & 220 & 99 \\
\hline $08 \ldots$ & 1345 & 1410 & 216 & 1.5 & 3.0 & 19 & 72 & -- \\
\hline $09 \ldots$ & 1100 & 1190 & 225 & -2.0 & 1.5 & 34 & 109 & -- \\
\hline $14 \ldots$ & 1245 & 942 & 288 & 2.5 & .5 & 10 & 25 & -- \\
\hline $16 \ldots$ & 1305 & 792 & 284 & 2.0 & .5 & 10 & 21 & -- \\
\hline $19 \ldots$ & 1410 & 854 & 292 & 2.0 & 2.0 & 9 & 21 & -- \\
\hline $22 \ldots$ & 1230 & 669 & 298 & 5.0 & 1.5 & 4 & 7.2 & -- \\
\hline $27 \ldots$ & 1050 & 1810 & 188 & 4.0 & 1.5 & 23 & 112 & -- \\
\hline $28 \ldots$ & 1110 & 1380 & 201 & 3.5 & 1.5 & 10 & 37 & -- \\
\hline $30 \ldots$ & 1300 & 841 & 251 & -7.0 & .0 & 14 & 32 & -- \\
\hline \multicolumn{9}{|l|}{ JAN } \\
\hline $03 \ldots$ & 1450 & 1390 & 260 & -1.0 & .0 & 14 & 53 & 92 \\
\hline $03 \ldots$ & 1500 & 1390 & 265 & -1.0 & .0 & 16 & 60 & 74 \\
\hline $03 \ldots$ & 1520 & 1390 & 263 & -1.0 & .0 & 14 & 53 & 82 \\
\hline $06 \ldots$ & 1300 & 1070 & 274 & .5 & .0 & 6 & 17 & -- \\
\hline $09 \ldots$ & 1030 & 1230 & 273 & .0 & .0 & 16 & 53 & -- \\
\hline $13 \ldots$ & 1225 & 962 & 311 & 9.0 & 2.0 & 14 & 36 & -- \\
\hline $18 \ldots$ & 1015 & 2190 & 206 & 5.0 & 4.0 & 52 & 307 & -- \\
\hline $20 \ldots$ & 1430 & 1680 & 186 & 5.5 & 4.0 & 28 & 127 & 72 \\
\hline $21 \ldots$ & 1115 & 2190 & 215 & 4.0 & 4.0 & 34 & 201 & 61 \\
\hline $21 \ldots$ & 1608 & 2300 & 220 & -- & 4.0 & 36 & 224 & 65 \\
\hline $21 \ldots$ & 1630 & 2300 & 221 & -- & 4.0 & 36 & 224 & 66 \\
\hline $21 \ldots$ & 1635 & 2300 & 222 & -- & 4.0 & 32 & 199 & 64 \\
\hline $23 \ldots$ & 1040 & 2710 & 171 & .0 & 2.0 & 28 & 205 & 84 \\
\hline
\end{tabular}


Appendix 2. Instantaneous suspended-sediment and associated data at three continuous-record and four partial-record sediment stations in the Housatonic River Basin, western Massachusetts, March 1994 through April 1996-Continued

\begin{tabular}{|c|c|c|c|c|c|c|c|c|}
\hline DATE & TIME & $\begin{array}{c}\text { DISCHARGE, } \\
\text { INST. CUBIC } \\
\text { FEET PER } \\
\text { SECOND } \\
(00061)\end{array}$ & $\begin{array}{c}\text { SPECIFIC } \\
\text { CONDUC- } \\
\text { TANCE LAB } \\
\text { (US/CM) } \\
(90095)\end{array}$ & $\begin{array}{l}\text { TEMPERA- } \\
\text { TURE AIR } \\
\text { (DEG C) } \\
\text { (00020) }\end{array}$ & $\begin{array}{l}\text { TEMPERA- } \\
\text { TURE WATER } \\
\text { (DEG C) } \\
(00010)\end{array}$ & $\begin{array}{c}\text { SEDIMENT, } \\
\text { SUSPENDED } \\
(M G / L) \\
(80154)\end{array}$ & $\begin{array}{c}\text { SEDIMENT, } \\
\text { DISCHARGE, } \\
\text { SUSPENDED } \\
\text { (T/DAY) } \\
(80155)\end{array}$ & $\begin{array}{l}\text { SED. SUSP. } \\
\text { SIEVE DIAM. } \\
\text { \% FINER THAN } \\
.062 \text { MM } \\
(70331)\end{array}$ \\
\hline
\end{tabular}

01198125 - HOUSATONIC RIVER NEAR ASHLEY FALLS, MA-Continued

WATER-QUALITY DATA, WATER YEAR OCTOBER 1994 TO SEPTEMBER 1995—Continued

\begin{tabular}{|c|c|c|c|c|c|c|c|c|}
\hline \multicolumn{9}{|c|}{ JAN_-Continued } \\
\hline $25 \ldots$ & 1100 & 1880 & 241 & 0.5 & 1.5 & 22 & 112 & -- \\
\hline $27 \ldots$ & 1300 & 1420 & 255 & -2.0 & .5 & 16 & 61 & -- \\
\hline $31 \ldots$ & 1305 & 1180 & 284 & 2.0 & .5 & 8 & 25 & -- \\
\hline \multicolumn{9}{|l|}{ FEB } \\
\hline $03 \ldots$ & 1250 & 795 & 276 & 3.5 & 0.0 & 9 & 19 & -- \\
\hline $22 \ldots$ & 1640 & 556 & 334 & 1.0 & 1.5 & 5 & 7.5 & -- \\
\hline $22 \ldots$ & 1645 & 556 & 343 & 1.0 & 1.5 & 7 & 11 & -- \\
\hline $24 \ldots$ & 1455 & 647 & 335 & 2.0 & 2.5 & 11 & 19 & -- \\
\hline \multicolumn{9}{|l|}{ MAR } \\
\hline $01 \ldots$ & 1020 & 1030 & 321 & 2.5 & 1.0 & 35 & 97 & 81 \\
\hline $03 \ldots$ & 1300 & 832 & 395 & 1.5 & 1.5 & 16 & 36 & 83 \\
\hline $06 \ldots$ & 1330 & 685 & 303 & 7.5 & 3.0 & 6 & 11 & -- \\
\hline $08 \ldots$ & 1310 & 1100 & 295 & 17.5 & 6.0 & 34 & 101 & 78 \\
\hline $10 \ldots$ & 1410 & 3990 & 174 & -2.0 & .5 & 91 & 980 & 50 \\
\hline $10 \ldots$ & 1415 & 3990 & 156 & -2.0 & .5 & 78 & 840 & 48 \\
\hline $11 \ldots$ & 1100 & 3600 & 172 & 4.0 & .5 & 44 & 428 & 57 \\
\hline $11 \ldots$ & 1105 & 3600 & 174 & 4.0 & .5 & 62 & 603 & 43 \\
\hline $12 \ldots$ & 1420 & 2410 & 206 & 6.0 & 2.0 & 39 & 254 & 59 \\
\hline $12 \ldots$ & 1425 & 2410 & 203 & 6.0 & 2.0 & 34 & 221 & 68 \\
\hline $13 \ldots$ & 1450 & 1960 & 220 & 15.0 & 4.0 & 24 & 127 & 75 \\
\hline $13 \ldots$ & 1455 & 1960 & 221 & 15.0 & 4.0 & 27 & 143 & 80 \\
\hline $14 \ldots$ & 1335 & 2010 & 218 & 18.5 & 5.0 & 26 & 141 & -- \\
\hline $14 \ldots$ & 1340 & 2010 & 229 & 18.5 & 5.0 & 24 & 130 & -- \\
\hline $14 \ldots$ & 1740 & 2000 & 231 & -- & 5.5 & 22 & 119 & 73 \\
\hline $14 \ldots$ & 1747 & 2000 & 225 & -- & 5.5 & 23 & 124 & 71 \\
\hline $15 \ldots$ & 1035 & 2050 & 226 & 12.0 & 5.0 & 33 & 183 & -- \\
\hline $15 \ldots$ & 1040 & 2050 & 228 & 12.0 & 5.0 & 34 & 188 & -- \\
\hline $17 \ldots$ & 1300 & 2140 & 213 & 14.0 & 7.0 & 30 & 173 & -- \\
\hline $17 \ldots$ & 1305 & 2140 & 199 & 14.0 & 7.0 & 33 & 191 & -- \\
\hline $18 \ldots$ & 1600 & 2040 & 205 & 9.0 & 6.5 & 34 & 187 & -- \\
\hline $18 \ldots$ & 1605 & 2040 & 209 & 9.0 & 6.5 & 28 & 154 & -- \\
\hline $19 \ldots$ & 1430 & 1860 & 216 & 19.5 & 6.5 & 15 & 75 & -- \\
\hline $19 \ldots$ & 1435 & 1860 & 203 & 19.5 & 6.5 & 20 & 100 & -- \\
\hline $20 \ldots$ & 1045 & 1660 & 220 & 12.0 & 6.0 & 15 & 67 & -- \\
\hline $20 \ldots$ & 1050 & 1660 & 223 & 12.0 & 6.0 & 21 & 94 & -- \\
\hline $23 \ldots$ & 1330 & 1590 & 241 & 5.5 & 6.0 & 16 & 69 & -- \\
\hline $23 \ldots$ & 1336 & 1590 & 230 & 5.5 & 6.0 & 21 & 90 & -- \\
\hline $28 \ldots$ & 1425 & 916 & 274 & 11.5 & 7.0 & 10 & 25 & -- \\
\hline $28 \ldots$ & 1430 & 916 & 283 & 11.5 & 7.0 & 10 & 25 & -- \\
\hline $31 \ldots$ & 1300 & 823 & 299 & 8.5 & 8.0 & 11 & 24 & -- \\
\hline $31 \ldots$ & 1305 & 823 & 296 & 8.5 & 8.0 & 10 & 22 & -- \\
\hline \multicolumn{9}{|l|}{ APR } \\
\hline $03 \ldots$ & 1430 & 704 & 288 & 11.5 & 7.0 & 6 & 11 & -- \\
\hline $03 \ldots$ & 1435 & 704 & 306 & 11.5 & 7.0 & 6 & 11 & -- \\
\hline $07 \ldots$ & 1320 & 656 & 307 & 10.5 & 5.0 & 5 & 8.9 & -- \\
\hline $10 \ldots$ & 1340 & 734 & 305 & 12.5 & 5.5 & 5 & 9.9 & -- \\
\hline $13 \ldots$ & 0850 & 826 & 263 & 15.5 & 7.5 & 41 & 91 & 77 \\
\hline $13 \ldots$ & 1620 & 1010 & 277 & -- & 8.5 & 30 & 81 & 82 \\
\hline $14 \ldots$ & 1022 & 1290 & 283 & 8.0 & 8.0 & 32 & 111 & 78 \\
\hline
\end{tabular}


Appendix 2. Instantaneous suspended-sediment and associated data at three continuous-record and four partial-record sediment stations in the Housatonic River Basin, western Massachusetts, March 1994 through April 1996—Continued

\begin{tabular}{|c|c|c|c|c|c|c|c|c|}
\hline DATE & TIME & $\begin{array}{c}\text { DISCHARGE, } \\
\text { INST. CUBIC } \\
\text { FEET PER } \\
\text { SECOND } \\
(00061)\end{array}$ & $\begin{array}{c}\text { SPECIFIC } \\
\text { CONDUC- } \\
\text { TANCE LAB } \\
\text { (US/CM) } \\
(90095)\end{array}$ & $\begin{array}{c}\text { TEMPERA- } \\
\text { TURE AIR } \\
\text { (DEG C) } \\
(00020)\end{array}$ & $\begin{array}{l}\text { TEMPERA- } \\
\text { TURE WATER } \\
\text { (DEG C) } \\
(00010)\end{array}$ & $\begin{array}{c}\text { SEDIMENT, } \\
\text { SUSPENDED } \\
\text { (MG/L) } \\
(\mathbf{8 0 1 5 4 )}\end{array}$ & $\begin{array}{c}\text { SEDIMENT, } \\
\text { DISCHARGE, } \\
\text { SUSPENDED } \\
\text { (T/DAY) } \\
(80155)\end{array}$ & $\begin{array}{l}\text { SED. SUSP. } \\
\text { SIEVE DIAM. } \\
\text { \% FINER THAN } \\
.062 \mathrm{MM} \\
(70331)\end{array}$ \\
\hline
\end{tabular}

01198125 - HOUSATONIC RIVER NEAR ASHLEY FALLS, MA-Continued

WATER-QUALITY DATA, WATER YEAR OCTOBER 1994 TO SEPTEMBER 1995—Continued

\begin{tabular}{|c|c|c|c|c|c|c|c|c|}
\hline \multicolumn{9}{|c|}{ APR_Continued } \\
\hline $14 \ldots$ & 1105 & 1290 & 280 & 15.5 & 7.5 & 48 & 167 & 64 \\
\hline $17 \ldots$ & 1415 & 816 & 247 & 15.0 & 8.0 & 5 & 11 & -- \\
\hline $20 \ldots$ & 1500 & 1100 & 276 & 17.0 & 11.5 & 16 & 48 & -- \\
\hline $22 \ldots$ & 1133 & 1040 & 244 & -- & 12.0 & 11 & 31 & -- \\
\hline $23 \ldots$ & 1430 & 972 & 267 & 14.0 & 11.0 & 9 & 24 & -- \\
\hline $26 \ldots$ & 1145 & 718 & 283 & 17.0 & 12.0 & 5 & 9.7 & -- \\
\hline $30 \ldots$ & 1430 & 682 & 284 & 18.5 & 13.5 & 4 & 7.4 & -- \\
\hline \multicolumn{9}{|l|}{ MAY } \\
\hline $03 \ldots$ & 1255 & 604 & 311 & 21.0 & 12.0 & 3 & 4.9 & -- \\
\hline $06 \ldots$ & 1000 & 565 & 324 & 13.0 & 11.5 & 4 & 6.1 & -- \\
\hline $09 \ldots$ & 1055 & 497 & 328 & 20.0 & 13.0 & 3 & 4.0 & -- \\
\hline $12 \ldots$ & 1300 & 539 & 324 & 20.5 & 13.0 & 3 & 4.4 & -- \\
\hline $19 \ldots$ & 1130 & 497 & 321 & 22.0 & 14.5 & 4 & 5.4 & -- \\
\hline $21 \ldots$ & 1400 & 431 & 330 & 26.0 & 16.5 & 4 & 4.7 & -- \\
\hline $24 \ldots$ & 1030 & 361 & 325 & 23.0 & 17.0 & 4 & 3.9 & -- \\
\hline $30 \ldots$ & 1223 & 448 & 338 & -- & 17.0 & 4 & 4.8 & -- \\
\hline $30 \ldots$ & 1525 & 473 & 338 & 20.5 & 17.5 & 5 & 6.4 & -- \\
\hline \multicolumn{9}{|l|}{ JUN } \\
\hline $02 \ldots$ & 1105 & 335 & 327 & 25.5 & 20.0 & 6 & 5.4 & -- \\
\hline $05 \ldots$ & 1405 & 650 & 316 & 28.0 & 21.5 & 18 & 32 & 64 \\
\hline $12 \ldots$ & 1025 & 267 & 332 & 17.0 & 19.0 & 7 & 5.0 & -- \\
\hline $14 \ldots$ & 1555 & 326 & 347 & -- & 18.5 & 7 & 6.2 & -- \\
\hline $16 \ldots$ & 1300 & 273 & 349 & 27.0 & 20.0 & 4 & 2.9 & -- \\
\hline $20 \ldots$ & 1520 & 205 & 346 & 34.0 & 26.0 & 17 & 9.4 & -- \\
\hline $23 \ldots$ & 1130 & 179 & 375 & 25.5 & 22.0 & 11 & 5.3 & -- \\
\hline $26 \ldots$ & 1030 & 155 & 380 & 29.0 & 23.5 & 9 & 3.8 & -- \\
\hline $30 \ldots$ & 1055 & 143 & 402 & 30.0 & 23.0 & 5 & 1.9 & -- \\
\hline \multicolumn{9}{|l|}{ JUL } \\
\hline $03 \ldots$ & 1420 & 241 & 422 & 26.0 & 23.0 & 4 & 2.6 & -- \\
\hline $07 \ldots$ & 1405 & 130 & 367 & 24.5 & 24.0 & 9 & 3.2 & -- \\
\hline $11 \ldots$ & 1135 & 137 & 375 & 25.0 & 22.5 & 10 & 3.7 & -- \\
\hline $14 \ldots$ & 1255 & 183 & 412 & 42.5 & 26.5 & 4 & 2.0 & -- \\
\hline $17 \ldots$ & 1115 & 142 & 420 & 29.0 & 25.5 & 6 & 2.3 & -- \\
\hline $21 \ldots$ & 1120 & 123 & 403 & 29.0 & 24.5 & 5 & 1.7 & -- \\
\hline $25 \ldots$ & 1110 & 125 & 391 & 28.0 & 26.0 & 4 & 1.4 & -- \\
\hline $29 \ldots$ & 1405 & 145 & 414 & 34.5 & 28.5 & 3 & 1.2 & -- \\
\hline \multicolumn{9}{|l|}{ AUG } \\
\hline $02 \ldots$ & 1040 & 118 & 397 & 35.0 & 27.0 & 4 & 1.3 & -- \\
\hline $05 \ldots$ & 1040 & 148 & 349 & 28.0 & 26.5 & 3 & 1.2 & -- \\
\hline $08 \ldots$ & 1115 & 342 & 355 & 27.5 & 22.5 & 9 & 8.3 & 45 \\
\hline $08 \ldots$ & 1605 & 321 & 359 & 27.5 & 23.5 & 8 & 6.9 & -- \\
\hline $08 \ldots$ & 1610 & 321 & 360 & 27.5 & 23.5 & 7 & 6.1 & -- \\
\hline $11 \ldots$ & 0940 & 151 & 352 & 24.0 & 24.0 & 11 & 4.5 & -- \\
\hline $18 \ldots$ & 1320 & 105 & 396 & 32.0 & 26.5 & 3 & .85 & -- \\
\hline $25 \ldots$ & 1330 & 74 & 413 & 23.5 & 21.5 & 2 & .40 & -- \\
\hline $28 \ldots$ & 1048 & 71 & 466 & 24.5 & 20.0 & 4 & .77 & -- \\
\hline \multicolumn{9}{|l|}{ SEP } \\
\hline $01 \ldots$ & 1325 & 73 & 470 & 26.0 & 21.5 & 4 & .79 & -- \\
\hline $08 \ldots$ & 1315 & 67 & 501 & 16.0 & 20.5 & 7 & 1.3 & -- \\
\hline
\end{tabular}


Appendix 2. Instantaneous suspended-sediment and associated data at three continuous-record and four partial-record sediment stations in the Housatonic River Basin, western Massachusetts, March 1994 through April 1996-Continued

\begin{tabular}{|c|c|c|c|c|c|c|c|c|}
\hline DATE & TIME & $\begin{array}{c}\text { DISCHARGE, } \\
\text { INST. CUBIC } \\
\text { FEET PER } \\
\text { SECOND } \\
(00061)\end{array}$ & $\begin{array}{c}\text { SPECIFIC } \\
\text { CONDUC- } \\
\text { TANCE LAB } \\
(\text { US/CM) } \\
(90095)\end{array}$ & $\begin{array}{c}\text { TEMPERA- } \\
\text { TURE AIR } \\
\text { (DEG C) } \\
(00020)\end{array}$ & $\begin{array}{l}\text { TEMPERA- } \\
\text { TURE WATER } \\
\text { (DEG C) } \\
(00010)\end{array}$ & $\begin{array}{c}\text { SEDIMENT, } \\
\text { SUSPENDED } \\
\text { (MG/L) } \\
(\mathbf{8 0 1 5 4 )}\end{array}$ & $\begin{array}{c}\text { SEDIMENT, } \\
\text { DISCHARGE, } \\
\text { SUSPENDED } \\
\text { (T/DAY) } \\
(\mathbf{8 0 1 5 5 )}\end{array}$ & $\begin{array}{l}\text { SED. SUSP. } \\
\text { SIEVE DIAM. } \\
\text { \% FINER THAN } \\
.062 \text { MM } \\
(70331)\end{array}$ \\
\hline \multicolumn{9}{|c|}{$\begin{array}{l}\text { 01198125 - HOUSATONIC RIVER NEAR ASHLEY FALLS, MA-Continued } \\
\text { WATER-QUALITY DATA, WATER YEAR OCTOBER } 1994 \text { TO SEPTEMBER 1995-Continued }\end{array}$} \\
\hline \multicolumn{9}{|c|}{ SEP-Continued } \\
\hline $11 \ldots$ & 1415 & 75 & 494 & 20.5 & 17.5 & 3 & 0.61 & -- \\
\hline $15 \ldots$ & 1312 & 87 & 514 & 17.5 & 18.5 & 2 & .47 & -- \\
\hline $18 \ldots$ & 1025 & 103 & 524 & 15.0 & 16.0 & 4 & 1.1 & -- \\
\hline $22 \ldots$ & 1317 & 90 & 539 & 20.0 & 17.5 & 8 & 1.9 & -- \\
\hline $25 \ldots$ & 1025 & 160 & 511 & 15.0 & 14.5 & 7 & 3.0 & -- \\
\hline $29 \ldots$ & 1330 & 117 & 459 & 19.0 & 15.0 & 3 & .95 & -- \\
\hline
\end{tabular}

\begin{tabular}{|c|c|c|c|c|c|c|c|c|}
\hline \multicolumn{9}{|c|}{ WATER-QUALITY DATA, WATER YEAR OCTOBER 1995 TO SEPTEMBER 1996} \\
\hline \multicolumn{9}{|l|}{ OCT } \\
\hline $05 \ldots$ & 1725 & 184 & 432 & -- & 16.0 & 3 & 1.5 & -- \\
\hline $05 \ldots$ & 2230 & 241 & 396 & -- & 15.5 & 5 & 3.3 & -- \\
\hline $06 \ldots$ & 0800 & 426 & 397 & -- & 15.0 & 8 & 9.2 & -- \\
\hline $06 \ldots$ & 0805 & 426 & 397 & -- & 15.0 & 5 & 5.8 & -- \\
\hline $06 \ldots$ & 1125 & 511 & 384 & -- & 15.0 & 13 & 18 & -- \\
\hline $06 \ldots$ & 1325 & 562 & 357 & 17.0 & 15.0 & 20 & 30 & -- \\
\hline $06 \ldots$ & 1710 & 669 & 341 & -- & 15.5 & 21 & 38 & 87 \\
\hline $07 \ldots$ & 1040 & 926 & 394 & 12.5 & 14.5 & 26 & 65 & -- \\
\hline $11 \ldots$ & 1045 & 324 & 314 & 20.0 & 13.5 & 10 & 8.7 & -- \\
\hline $16 \ldots$ & 1030 & 622 & 346 & 11.5 & 13.0 & 11 & 18 & -- \\
\hline $19 \ldots$ & 1115 & 371 & 309 & 18.5 & 11.5 & 8 & 8.0 & -- \\
\hline $22 \ldots$ & 0405 & 1030 & 288 & -- & 13.5 & 14 & 39 & -- \\
\hline $22 \ldots$ & 1003 & 1610 & 234 & -- & 13.0 & 73 & 317 & 90 \\
\hline $22 \ldots$ & 1005 & 1630 & 240 & -- & 13.0 & 95 & 418 & -- \\
\hline $22 \ldots$ & 1405 & 1870 & 241 & 13.5 & 13.0 & 89 & 449 & -- \\
\hline $22 \ldots$ & 1420 & 1890 & 237 & 13.5 & 13.0 & 89 & 454 & 93 \\
\hline $22 \ldots$ & 1710 & 1990 & 264 & -- & 13.5 & 50 & 269 & 82 \\
\hline $22 \ldots$ & 1714 & 1990 & 255 & -- & 13.5 & 84 & 451 & 85 \\
\hline $22 \ldots$ & 1735 & 1990 & 266 & -- & 13.5 & 47 & 253 & 77 \\
\hline $23 \ldots$ & 1030 & 2280 & 213 & 15.5 & 12.0 & 78 & 480 & -- \\
\hline $23 \ldots$ & 1035 & 2280 & 216 & 15.5 & 12.0 & 80 & 492 & -- \\
\hline $23 \ldots$ & 1303 & 2310 & 200 & -- & 13.0 & 73 & 455 & 64 \\
\hline $23 \ldots$ & 1305 & 2310 & 202 & -- & 13.0 & 80 & 499 & -- \\
\hline $23 \ldots$ & 1651 & 2330 & 185 & -- & 13.0 & 70 & 440 & 72 \\
\hline $23 \ldots$ & 1658 & 2330 & 180 & -- & 13.0 & 80 & 503 & 65 \\
\hline $23 \ldots$ & 1715 & 2330 & 182 & -- & 13.0 & 66 & 415 & 62 \\
\hline $24 \ldots$ & 1020 & 2170 & 174 & 16.5 & 12.0 & 48 & 281 & -- \\
\hline $24 \ldots$ & 1025 & 2170 & 181 & 16.5 & 12.0 & 45 & 264 & -- \\
\hline $26 \ldots$ & 1120 & 997 & 227 & 13.0 & 11.5 & 21 & 57 & -- \\
\hline $28 \ldots$ & 1202 & 1710 & 204 & -- & 13.0 & 96 & 443 & 74 \\
\hline $28 \ldots$ & 1658 & 1970 & 221 & -- & 13.0 & 40 & 213 & -- \\
\hline $28 \ldots$ & 2246 & 2340 & 192 & -- & 12.0 & 65 & 411 & 76 \\
\hline $29 \ldots$ & 0913 & 2900 & 192 & -- & 11.0 & 80 & 626 & 66 \\
\hline $29 \ldots$ & 1700 & 3070 & 177 & -- & 10.0 & 76 & 630 & 76 \\
\hline $29 \ldots$ & 1703 & 3070 & 174 & -- & 10.0 & 68 & 564 & -- \\
\hline $30 \ldots$ & 1025 & 2950 & 169 & 8.0 & 10.0 & 51 & 406 & -- \\
\hline $30 \ldots$ & 1030 & 2950 & 168 & 8.0 & 10.0 & 35 & 279 & 86 \\
\hline \multicolumn{9}{|l|}{ NOV } \\
\hline $02 \ldots$ & 1345 & 1290 & 225 & 11.5 & 8.5 & 16 & 56 & -- \\
\hline $06 \ldots$ & 1015 & 929 & 260 & 6.0 & 5.5 & 13 & 33 & -- \\
\hline
\end{tabular}


Appendix 2. Instantaneous suspended-sediment and associated data at three continuous-record and four partial-record sediment stations in the Housatonic River Basin, western Massachusetts, March 1994 through April 1996—Continued

\begin{tabular}{|c|c|c|c|c|c|c|c|c|}
\hline DATE & TIME & $\begin{array}{c}\text { DISCHARGE, } \\
\text { INST. CUBIC } \\
\text { FEET PER } \\
\text { SECOND } \\
(00061)\end{array}$ & $\begin{array}{c}\text { SPECIFIC } \\
\text { CONDUC- } \\
\text { TANCE LAB } \\
\text { (US/CM) } \\
(90095)\end{array}$ & $\begin{array}{c}\text { TEMPERA- } \\
\text { TURE AIR } \\
\text { (DEG C) } \\
(00020)\end{array}$ & $\begin{array}{l}\text { TEMPERA- } \\
\text { TURE WATER } \\
\text { (DEG C) } \\
(00010)\end{array}$ & $\begin{array}{l}\text { SEDIMENT, } \\
\text { SUSPENDED } \\
\text { (MG/L) } \\
(\mathbf{8 0 1 5 4 )}\end{array}$ & $\begin{array}{c}\text { SEDIMENT, } \\
\text { DISCHARGE, } \\
\text { SUSPENDED } \\
\text { (T/DAY) } \\
(\mathbf{8 0 1 5 5 )}\end{array}$ & $\begin{array}{l}\text { SED. SUSP. } \\
\text { SIEVE DIAM. } \\
\text { \% FINER THAN } \\
.062 \text { MM } \\
(70331)\end{array}$ \\
\hline \multicolumn{9}{|c|}{$\begin{array}{l}\text { 01198125 - HOUSATONIC RIVER NEAR ASHLEY FALLS, MA-Continued } \\
\text { WATER-QUALITY DATA, WATER YEAR OCTOBER } 1995 \text { TO SEPTEMBER 1996-Continued }\end{array}$} \\
\hline
\end{tabular}

NOV-Continued

$10 \ldots$

$12 \ldots \quad 1350$

$12 \ldots \quad 1355$

$12 \ldots \quad 1710$

$13 \ldots \quad 1335$

$13 \ldots . \quad 1340$

$14 \ldots \quad 1035$

$14 \ldots \quad 1040$

$15 \ldots . \quad 1245$

$15 \ldots . \quad 1250$

$17 \ldots \quad 1325$

$17 \ldots \quad 1330$

$21 \ldots \quad 1345$

$24 \ldots \quad 1320$

$30 \ldots \quad 1435$

DEC

$\begin{array}{lll}08 \ldots & 0920 & 764\end{array}$

JAN

$\begin{array}{lll}20 \ldots & 1100 & 3790\end{array}$

$\begin{array}{lll}20 \ldots & 1107 & 3790\end{array}$

$20 \ldots \quad 1114$

$20 \ldots \quad 1337$

$20 \ldots \quad 1339$

$21 \ldots \quad 0925$

$21 \ldots \quad 0935$

$21 \ldots \quad 1256$

$21 \ldots \quad 1259$

$22 \ldots \quad 1659$

$22 \ldots \quad 1701$

$24 \ldots \quad 1729$

$25 \ldots . \quad 1145$

$25 \ldots \quad 1148$

$28 \ldots \quad 1055$

$28 \ldots .1059$

$28 \ldots . \quad 1610$

$28 \ldots . \quad 1617$

$28 \ldots .1619$

$29 \ldots \quad 1414$

$29 \ldots . \quad 1416$

FEB

$10 \ldots \quad 1025 \quad 1240$

$22 \ldots \quad 1330$

$22 \ldots \quad 1333$

$22 \ldots \quad 1725$

23... 0930

$23 \ldots \quad 0932$

$23 \ldots \quad 1325$

$23 \ldots \quad 1330$

$26 \ldots \quad 1050$

$26 \ldots . \quad 1055$
972

1960

1960

2270

3270

3270

3410

3300

3300

2760

2760

1160

891

3790
3790

4660

4660

6940

6940

7030

7030

6340

6340

3740

4540

4540

6020

6020

6020

6020

6020

5930

5930

1240
2550

2550

2750

3190

3190

3220

3220

2920

2920

\section{3}

229

236

208

193

199

168

171

186

185

196

204

226

258

286

298

248

243

247

210

214

207

212

205

210

192

197

211

203

202

170

175

173

173

167

165

169

282

277

278

259

262

265

237

235

192

197

\section{5}

2.5

2.5

$--$

1.5

1.5

4.0

$$
4.0
$$

$$
6.0
$$$$
6.0
$$$$
3.0
$$$$
3.0
$$

10.5

2.0

1.5

4.0

$\begin{array}{ll}-- & .0 \\ -- & 0\end{array}$

$-0$

$\begin{array}{ll}- & .0 \\ - & 0\end{array}$

$--$

$-$

$-$

$-$

$-$

$--$

$-$

$-$

$-$

$--$

$-$

$-$

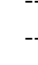

$-$

$-$

$--$

$-$

--

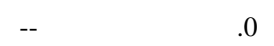

$7.0 \quad .5$
-5

$\begin{array}{ll}-- & 1.0\end{array}$

$\begin{array}{ll}-- & 1.0\end{array}$

$\begin{array}{ll}- & 1.0 \\ - & 1.5\end{array}$

$\begin{array}{ll}-- & 1.5\end{array}$

$\begin{array}{ll}-- & 1.5\end{array}$

$11.5 \quad 2.0$

$\begin{array}{ll}11.5 & 2.0\end{array}$

$6.5 \quad 2.0$

$\begin{array}{ll}6.5 & 2.0\end{array}$

$\begin{array}{rr}11 & \\ 109 & 577 \\ 52 & 275 \\ 92 & 564 \\ 63 & 5 \\ 73 & 6 \\ 78 & 7 \\ 68 & 626 \\ 34 & 3 \\ 39 & 3 \\ 34 & 253 \\ 29 & 2 \\ 15 & \\ 12 & \\ 10 & \\ & \\ 11 & \end{array}$

29
577
275

275

$556 \quad 53$

645 - --

$718 \quad 33$

626

$303-66$

$253-4$

216

67

38

23

1430

1400

1560

1930

1380

1370

956

1200

1140

411

$$
616
$$$$
525
$$

1190

1040

1850

2450

1670

1760

1090

1260

993

90
599

599

$$
647
$$

720

1010

$$
922
$$$$
1020
$$$$
843
$$$$
473
$$

465 
Appendix 2. Instantaneous suspended-sediment and associated data at three continuous-record and four partial-record sediment stations in the Housatonic River Basin, western Massachusetts, March 1994 through April 1996-Continued

\begin{tabular}{|c|c|c|c|c|c|c|c|c|}
\hline DATE & TIME & $\begin{array}{l}\text { DISCHARGE, } \\
\text { INST. CUBIC } \\
\text { FEET PER } \\
\text { SECOND } \\
(00061)\end{array}$ & $\begin{array}{c}\text { SPECIFIC } \\
\text { CONDUC- } \\
\text { TANCE LAB } \\
(\text { US/CM) } \\
(90095)\end{array}$ & $\begin{array}{c}\text { TEMPERA- } \\
\text { TURE AIR } \\
\text { (DEG C) } \\
(00020)\end{array}$ & $\begin{array}{l}\text { TEMPERA- } \\
\text { TURE WATER } \\
\text { (DEG C) } \\
(00010)\end{array}$ & $\begin{array}{c}\text { SEDIMENT, } \\
\text { SUSPENDED } \\
\text { (MG/L) } \\
(\mathbf{8 0 1 5 4 )}\end{array}$ & $\begin{array}{c}\text { SEDIMENT, } \\
\text { DISCHARGE, } \\
\text { SUSPENDED } \\
\text { (T/DAY) } \\
\text { (80155) }\end{array}$ & $\begin{array}{l}\text { SED. SUSP. } \\
\text { SIEVE DIAM. } \\
\text { \% FINER THAN } \\
.062 \text { MM } \\
(\mathbf{7 0 3 3 1})\end{array}$ \\
\hline \multicolumn{9}{|c|}{$\begin{array}{l}\text { 01198125 - HOUSATONIC RIVER NEAR ASHLEY FALLS, MA-Continued } \\
\text { WATER-QUALITY DATA, WATER YEAR OCTOBER } 1995 \text { TO SEPTEMBER 1996-Continued }\end{array}$} \\
\hline \multicolumn{9}{|l|}{ MAR } \\
\hline $01 \ldots$ & 1325 & 1900 & 218 & 0.5 & 1.0 & 24 & 123 & -- \\
\hline $01 \ldots$ & 1330 & 1900 & 222 & 0.5 & 1.0 & 36 & 185 & -- \\
\hline $15 \ldots$ & 1025 & 1240 & 311 & 8.0 & 4.0 & 28 & 94 & -- \\
\hline $20 \ldots$ & 1600 & 1480 & 259 & -- & 4.5 & 10 & 40 & -- \\
\hline $20 \ldots$ & 1605 & 1480 & 260 & -- & 4.5 & 13 & 52 & -- \\
\hline $23 \ldots$ & 1220 & 1560 & 249 & 2.0 & 2.5 & 14 & 59 & -- \\
\hline $29 \ldots$ & 1325 & 1220 & 243 & 8.5 & 4.5 & 6 & 20 & -- \\
\hline $29 \ldots$ & 1330 & 1220 & 238 & 8.5 & 4.5 & 6 & 20 & -- \\
\hline \multicolumn{9}{|l|}{ APR } \\
\hline $01 \ldots$ & 1405 & 1030 & 261 & -- & 7.5 & 5 & 14 & -- \\
\hline $01 \ldots$ & 1408 & 1030 & 262 & -- & 7.5 & 5 & 14 & -- \\
\hline
\end{tabular}

01198200 - KONKAPOT RIVER AT ASHLEY FALLS, MA

WATER-QUALITY DATA, WATER YEAR OCTOBER 1993 TO SEPTEMBER 1994

\begin{tabular}{|c|c|c|c|c|c|c|c|c|}
\hline \multicolumn{9}{|l|}{ MAR } \\
\hline $29 \ldots$ & 1020 & 412 & -- & 4.5 & 1.5 & 424 & 472 & -- \\
\hline \multicolumn{9}{|l|}{ APR } \\
\hline $07 \ldots$ & 1600 & 581 & -- & 5.0 & 4.0 & 164 & 257 & 40 \\
\hline $08 \ldots$ & 1020 & 490 & -- & 4.0 & 3.0 & 77 & 102 & 37 \\
\hline $14 \ldots$ & 1420 & 743 & -- & 19.0 & 6.5 & 609 & 1220 & 7 \\
\hline $14 \ldots$ & 1835 & 699 & -- & 17.5 & 7.5 & 118 & 223 & 31 \\
\hline \multicolumn{9}{|l|}{ AUG } \\
\hline $03 \ldots$ & 1740 & 91 & 228 & 29.0 & 23.0 & 2 & .49 & -- \\
\hline $23 \ldots$ & 1830 & 145 & 182 & 19.5 & 18.0 & 9 & 3.5 & 58 \\
\hline \multicolumn{9}{|l|}{ SEP } \\
\hline $08 \ldots$ & 0825 & 27 & 312 & 15.0 & 14.0 & 2 & .15 & -- \\
\hline
\end{tabular}

\begin{tabular}{|c|c|c|c|c|c|c|c|c|}
\hline \multicolumn{9}{|l|}{ NOV } \\
\hline $29 \ldots$ & 1505 & 200 & 148 & 10.5 & 4.0 & 34 & 18 & 56 \\
\hline \multicolumn{9}{|l|}{ DEC } \\
\hline $06 \ldots$ & 1130 & 288 & 130 & 13.5 & 6.0 & 58 & 45 & 35 \\
\hline \multicolumn{9}{|l|}{ JAN } \\
\hline $21 \ldots$ & 1509 & 422 & 128 & 3.0 & 3.5 & 93 & 106 & 36 \\
\hline \multicolumn{9}{|l|}{ APR } \\
\hline $13 \ldots$ & 0818 & 305 & 185 & -- & 7.0 & 257 & 212 & 68 \\
\hline $13 \ldots$ & 1100 & 322 & 153 & -- & 7.5 & 266 & 231 & 52 \\
\hline $13 \ldots$ & 1221 & 328 & 150 & -- & 7.5 & 157 & 139 & 58 \\
\hline \multicolumn{9}{|l|}{ MAY } \\
\hline $30 \ldots$ & 1132 & 106 & 245 & -- & 18.0 & 19 & 5.4 & 59 \\
\hline \multicolumn{9}{|l|}{ SEP } \\
\hline $08 \ldots$ & 1330 & 9.1 & 372 & 18.0 & 18.5 & 2 & .05 & -- \\
\hline $11 \ldots$ & 1440 & 9.1 & 329 & 22.5 & 15.5 & 1 & .02 & -- \\
\hline $15 \ldots$ & 1340 & 11 & 345 & 20.5 & 16.0 & 1 & .03 & -- \\
\hline $18 \ldots$ & 1045 & 18 & 335 & 15.5 & 14.0 & 5 & .24 & -- \\
\hline $22 \ldots$ & 1450 & 16 & 328 & -- & 16.0 & 4 & .17 & -- \\
\hline $23 \ldots$ & 1030 & 43 & 289 & 14.5 & 13.5 & 6 & .70 & -- \\
\hline $25 \ldots$ & 1040 & 18 & 295 & 16.5 & 12.5 & 3 & .15 & -- \\
\hline $29 \ldots$ & 1345 & 16 & 314 & 19.5 & 12.5 & 3 & .13 & -- \\
\hline
\end{tabular}


Appendix 2. Instantaneous suspended-sediment and associated data at three continuous-record and four partial-record sediment stations in the Housatonic River Basin, western Massachusetts, March 1994 through April 1996—Continued

\begin{tabular}{|c|c|c|c|c|c|c|c|c|}
\hline DATE & TIME & $\begin{array}{c}\text { DISCHARGE, } \\
\text { INST. CUBIC } \\
\text { FEET PER } \\
\text { SECOND } \\
(00061)\end{array}$ & $\begin{array}{c}\text { SPECIFIC } \\
\text { CONDUC- } \\
\text { TANCE LAB } \\
\text { (US/CM) } \\
(90095)\end{array}$ & $\begin{array}{c}\text { TEMPERA- } \\
\text { TURE AIR } \\
\text { (DEG C) } \\
(00020)\end{array}$ & $\begin{array}{l}\text { TEMPERA- } \\
\text { TURE WATER } \\
\text { (DEG C) } \\
(00010)\end{array}$ & $\begin{array}{l}\text { SEDIMENT, } \\
\text { SUSPENDED } \\
\text { (MG/L) } \\
(\mathbf{8 0 1 5 4 )}\end{array}$ & $\begin{array}{c}\text { SEDIMENT, } \\
\text { DISCHARGE, } \\
\text { SUSPENDED } \\
\text { (T/DAY) } \\
(\mathbf{8 0 1 5 5 )}\end{array}$ & $\begin{array}{c}\text { SED. SUSP. } \\
\text { SIEVE DIAM. } \\
\text { \% FINER THAN } \\
.062 \text { MM } \\
(70331)\end{array}$ \\
\hline
\end{tabular}

\begin{tabular}{|c|c|c|c|c|c|c|c|c|}
\hline \multicolumn{9}{|l|}{ OCT } \\
\hline $05 \ldots$ & 1545 & 21 & 321 & -- & 14.5 & 3 & 0.17 & -- \\
\hline $05 \ldots$ & 2240 & 45 & 289 & -- & 14.5 & 13 & 1.6 & -- \\
\hline $05 \ldots$ & 2247 & 45 & 297 & -- & 14.5 & 16 & 1.9 & -- \\
\hline $06 \ldots$ & 0820 & 166 & 260 & -- & 13.5 & 161 & 72 & 70 \\
\hline $06 \ldots$ & 0824 & 166 & 254 & -- & 13.5 & 174 & 78 & 71 \\
\hline $06 \ldots$ & 0835 & 170 & 253 & -- & 13.5 & 139 & 64 & 77 \\
\hline $06 \ldots$ & 1050 & 187 & 228 & -- & 13.5 & 152 & 77 & 57 \\
\hline $06 \ldots$ & 1053 & 187 & 239 & -- & 13.5 & 137 & 69 & 68 \\
\hline $06 \ldots$ & 1340 & 190 & 219 & 18.5 & 14.0 & 76 & 39 & 93 \\
\hline $06 \ldots$ & 1505 & 190 & 209 & -- & 14.5 & 85 & 44 & 49 \\
\hline $06 \ldots$ & 1508 & 190 & 219 & -- & 14.5 & 69 & 35 & 70 \\
\hline $06 \ldots$ & 1643 & 182 & 216 & -- & 14.5 & 76 & 37 & -- \\
\hline $07 \ldots$ & 1100 & 86 & 201 & 13.0 & 12.5 & 17 & 3.9 & -- \\
\hline $07 \ldots$ & 1105 & 27 & 280 & 21.5 & 11.5 & 6 & .44 & -- \\
\hline $13 \ldots$ & 1240 & 23 & 289 & -- & 13.0 & 2 & .12 & -- \\
\hline $16 \ldots$ & 1040 & 73 & 225 & 10.0 & 10.0 & 10 & 2.0 & -- \\
\hline $19 \ldots$ & 1135 & 55 & 226 & 19.0 & 10.0 & 8 & 1.2 & -- \\
\hline $22 \ldots$ & 0153 & 636 & 146 & -- & 13.0 & 266 & 457 & -- \\
\hline $22 \ldots$ & 0158 & 636 & 137 & -- & 13.0 & 323 & 555 & 36 \\
\hline $22 \ldots$ & 0418 & 646 & 138 & -- & 13.0 & 247 & 431 & -- \\
\hline $22 \ldots$ & 0421 & 646 & 136 & -- & 13.0 & 190 & 331 & 24 \\
\hline $22 \ldots$ & 0931 & 654 & 123 & -- & 12.0 & 158 & 279 & -- \\
\hline $22 \ldots$ & 0934 & 654 & 119 & -- & 12.0 & 194 & 343 & 29 \\
\hline $22 \ldots$ & 1350 & 641 & 116 & -- & 12.5 & 36 & 62 & 74 \\
\hline $22 \ldots$ & 1358 & 641 & 112 & -- & 12.5 & 94 & 163 & 39 \\
\hline $22 \ldots$ & 1414 & 641 & 113 & -- & 12.5 & 71 & 123 & 49 \\
\hline $22 \ldots$ & 1756 & 547 & 126 & -- & 12.5 & 72 & 106 & 40 \\
\hline $22 \ldots$ & 1800 & 547 & 123 & -- & 12.5 & 73 & 108 & -- \\
\hline $23 \ldots$ & 1055 & 177 & 183 & 19.0 & 11.0 & 20 & 9.6 & -- \\
\hline $23 \ldots$ & 1100 & 177 & 182 & 19.0 & 11.0 & 11 & 5.3 & 84 \\
\hline $23 \ldots$ & 1734 & 149 & 188 & -- & 12.5 & 14 & 5.6 & -- \\
\hline $24 \ldots$ & 1040 & 125 & 205 & 16.5 & 11.0 & 12 & 4.0 & -- \\
\hline $26 \ldots$ & 1135 & 98 & 222 & 13.5 & 10.0 & 11 & 2.9 & -- \\
\hline $28 \ldots$ & 0845 & 470 & 159 & -- & 13.5 & 393 & 499 & 60 \\
\hline $28 \ldots$ & 0858 & 508 & 153 & -- & 13.5 & 419 & 575 & 58 \\
\hline $28 \ldots$ & 0911 & 512 & 158 & -- & 13.5 & 364 & 503 & 53 \\
\hline $28 \ldots$ & 1224 & 660 & 123 & -- & 14.0 & 445 & 793 & 68 \\
\hline $28 \ldots$ & 1228 & 660 & 120 & -- & 14.0 & 415 & 740 & 70 \\
\hline $28 \ldots$ & 1251 & 681 & 118 & -- & 14.0 & 476 & 875 & 55 \\
\hline $28 \ldots$ & 1444 & 929 & 108 & -- & 14.0 & 344 & 863 & 59 \\
\hline $28 \ldots$ & 1446 & 941 & 116 & -- & 14.0 & 408 & 1040 & -- \\
\hline $28 \ldots$ & 1725 & 1180 & 107 & -- & 14.0 & 456 & 1450 & 27 \\
\hline $28 \ldots$ & 1728 & 1180 & 104 & -- & 14.0 & 384 & 1220 & 32 \\
\hline $28 \ldots$ & 1740 & 1230 & 105 & -- & 14.0 & 2150 & 7140 & 6 \\
\hline $28 \ldots$ & 1741 & 1230 & 108 & -- & 14.0 & 3400 & 11300 & 4 \\
\hline $28 \ldots$ & 2302 & 1200 & 91 & -- & 12.5 & 232 & 752 & 20 \\
\hline $28 \ldots$ & 2307 & 1200 & 99 & -- & 12.5 & 194 & 629 & -- \\
\hline $29 \ldots$ & 0931 & 911 & 99 & -- & 10.5 & 51 & 125 & 48 \\
\hline
\end{tabular}


Appendix 2. Instantaneous suspended-sediment and associated data at three continuous-record and four partial-record sediment stations in the Housatonic River Basin, western Massachusetts, March 1994 through April 1996-Continued

\begin{tabular}{|c|c|c|c|c|c|c|c|c|}
\hline ATE & TIME & $\begin{array}{l}\text { DISCHARGE, } \\
\text { INST. CUBIC } \\
\text { FEET PER } \\
\text { SECOND } \\
\text { (00061) }\end{array}$ & $\begin{array}{l}\text { SPECIFIC } \\
\text { CONDUC- } \\
\text { TANCE LAB } \\
\text { (US/CM) } \\
(90095)\end{array}$ & $\begin{array}{l}\text { TEMPERA- } \\
\text { TURE AIR } \\
\text { (DEG C) } \\
(00020)\end{array}$ & $\begin{array}{l}\text { TEMPERA- } \\
\text { TURE WATER } \\
\text { (DEG C) } \\
(00010)\end{array}$ & $\begin{array}{l}\text { SEDIMENT, } \\
\text { SUSPENDED } \\
\text { (MG/L) } \\
(80154)\end{array}$ & $\begin{array}{c}\text { SEDIMENT, } \\
\text { DISCHARGE, } \\
\text { SUSPENDED } \\
\text { (T/DAY) } \\
(80155)\end{array}$ & $\begin{array}{l}\text { SED. SUSP. } \\
\text { SIEVE DIAM. } \\
\text { \% FINER THAN } \\
.062 \mathrm{MM} \\
(70331)\end{array}$ \\
\hline
\end{tabular}

01198200 - KONKAPOT RIVER AT ASHLEY FALLS, MA—Continued

WATER-QUALITY DATA, WATER YEAR OCTOBER 1995 TO SEPTEMBER 1996—Continued

\begin{tabular}{|c|c|c|c|c|c|c|c|c|}
\hline \multicolumn{9}{|c|}{ OCT-Continued } \\
\hline $29 \ldots$ & 0933 & 911 & 100 & -- & 10.5 & 48 & 118 & -- \\
\hline $29 \ldots$ & 1640 & 595 & 130 & -- & 10.5 & 57 & 92 & 55 \\
\hline $30 \ldots$ & 1050 & 260 & 186 & 11.5 & 8.5 & 14 & 9.8 & 75 \\
\hline $30 \ldots$ & 1055 & 260 & 189 & 11.5 & 8.5 & 20 & 14 & -- \\
\hline \multicolumn{9}{|l|}{ NOV } \\
\hline $02 \ldots$ & 1405 & 210 & 205 & 11.0 & 9.0 & 17 & 9.6 & -- \\
\hline $07 \ldots$ & 1035 & 140 & 192 & 6.5 & 5.0 & 4 & 1.5 & -- \\
\hline $08 \ldots$ & 0828 & 224 & 192 & -- & 6.0 & 21 & 13 & -- \\
\hline $10 \ldots$ & 1335 & 125 & 199 & 7.0 & 4.0 & 8 & 2.7 & -- \\
\hline $12 \ldots$ & 0932 & 657 & 125 & -- & 7.5 & 339 & 601 & -- \\
\hline $12 \ldots$ & 0934 & 657 & 130 & -- & 7.5 & 339 & 601 & 59 \\
\hline $12 \ldots$ & 1145 & 717 & 118 & -- & 7.0 & 225 & 436 & -- \\
\hline $12 \ldots$ & 1149 & 717 & 113 & -- & 7.0 & 196 & 379 & 47 \\
\hline $12 \ldots$ & 1410 & 813 & 114 & 2.0 & 7.0 & 196 & 430 & -- \\
\hline $12 \ldots$ & 1415 & 813 & 110 & 2.0 & 7.0 & 129 & 283 & 50 \\
\hline $12 \ldots$ & 1639 & 870 & 103 & -- & 6.5 & 154 & 362 & -- \\
\hline $12 \ldots$ & 1640 & 870 & 109 & -- & 6.5 & 56 & 132 & 90 \\
\hline $13 \ldots$ & 1355 & 360 & 138 & 0.0 & 4.0 & 54 & 52 & 34 \\
\hline $13 \ldots$ & 1400 & 360 & 140 & 0.0 & 4.0 & 40 & 39 & -- \\
\hline $15 \ldots$ & 0920 & 498 & 145 & -- & 5.5 & 62 & 83 & -- \\
\hline $15 \ldots$ & 1310 & 496 & 134 & 4.5 & 4.5 & 80 & 107 & 29 \\
\hline $15 \ldots$ & 1315 & 496 & 132 & 4.5 & 4.5 & 64 & 86 & -- \\
\hline $17 \ldots$ & 1345 & 225 & 168 & 4.5 & 3.5 & 12 & 7.3 & -- \\
\hline $21 \ldots$ & 1405 & 174 & 192 & 8.5 & 5.5 & 6 & 2.8 & -- \\
\hline $24 \ldots$ & 1335 & 140 & 205 & 2.0 & 3.0 & 5 & 1.9 & -- \\
\hline $30 \ldots$ & 1450 & 102 & 221 & 1.5 & 1.5 & 9 & 2.5 & -- \\
\hline \multicolumn{9}{|l|}{ DEC } \\
\hline $08 \ldots$ & 0940 & 89 & 213 & 3.0 & .0 & 6 & 1.4 & -- \\
\hline \multicolumn{9}{|l|}{ JAN } \\
\hline $18 \ldots$ & 1255 & 78 & 226 & -- & 1.5 & 2 & .42 & -- \\
\hline $19 \ldots$ & 1619 & 541 & 156 & -- & 2.5 & 509 & 743 & 49 \\
\hline $19 \ldots$ & 1621 & 541 & 158 & -- & 2.5 & 473 & 691 & -- \\
\hline $19 \ldots$ & 1844 & 641 & 131 & -- & 2.0 & 574 & 993 & -- \\
\hline $19 \ldots$ & 1850 & 641 & 138 & -- & 2.0 & 508 & 879 & 54 \\
\hline $19 \ldots$ & 2300 & 824 & 114 & -- & .0 & 366 & 814 & -- \\
\hline $19 \ldots$ & 2319 & 824 & 108 & -- & .0 & 310 & 690 & 46 \\
\hline $20 \ldots$ & 0942 & 1210 & 88 & -- & .0 & 110 & 359 & -- \\
\hline $20 \ldots$ & 0950 & 1210 & 92 & -- & .0 & 107 & 350 & 24 \\
\hline $20 \ldots$ & 1505 & 1230 & 86 & -- & .0 & 123 & 408 & -- \\
\hline $20 \ldots$ & 1511 & 1230 & 90 & -- & .0 & 158 & 525 & 22 \\
\hline $21 \ldots$ & 1000 & 570 & 120 & -- & .0 & 37 & 57 & -- \\
\hline $21 \ldots$ & 1007 & 570 & 120 & -- & .0 & 38 & 58 & -- \\
\hline $22 \ldots$ & 0940 & 320 & 152 & 7.0 & .5 & 16 & 14 & -- \\
\hline $22 \ldots$ & 0945 & 320 & 157 & 7.0 & .5 & 28 & 24 & -- \\
\hline $22 \ldots$ & 1720 & 289 & 156 & -- & 1.0 & 43 & 34 & -- \\
\hline $24 \ldots$ & 1758 & 473 & 166 & -- & 3.0 & 245 & 313 & -- \\
\hline $24 \ldots$ & 1802 & 473 & 164 & -- & 3.0 & 265 & 338 & 59 \\
\hline $25 \ldots$ & 1022 & 870 & 95 & -- & .0 & 68 & 160 & -- \\
\hline $25 \ldots$ & 1027 & 870 & 96 & -- & .0 & 107 & 251 & -- \\
\hline
\end{tabular}


Appendix 2. Instantaneous suspended-sediment and associated data at three continuous-record and four partial-record sediment stations in the Housatonic River Basin, western Massachusetts, March 1994 through April 1996-Continued

\begin{tabular}{|c|c|c|c|c|c|c|c|c|}
\hline DATE & TIME & $\begin{array}{c}\text { DISCHARGE, } \\
\text { INST. CUBIC } \\
\text { FEET PER } \\
\text { SECOND } \\
(00061)\end{array}$ & $\begin{array}{c}\text { SPECIFIC } \\
\text { CONDUC- } \\
\text { TANCE LAB } \\
\text { (US/CM) } \\
(90095)\end{array}$ & $\begin{array}{c}\text { TEMPERA- } \\
\text { TURE AIR } \\
\text { (DEG C) } \\
(00020)\end{array}$ & $\begin{array}{l}\text { TEMPERA- } \\
\text { TURE WATER } \\
\text { (DEG C) } \\
(00010)\end{array}$ & $\begin{array}{c}\text { SEDIMENT, } \\
\text { SUSPENDED } \\
\text { (MG/L) } \\
(\mathbf{8 0 1 5 4 )}\end{array}$ & $\begin{array}{c}\text { SEDIMENT, } \\
\text { DISCHARGE, } \\
\text { SUSPENDED } \\
\text { (T/DAY) } \\
\text { (80155) }\end{array}$ & $\begin{array}{l}\text { SED. SUSP. } \\
\text { SIEVE DIAM. } \\
\text { \% FINER THAN } \\
.062 \text { MM } \\
(\mathbf{7 0 3 3 1 )}\end{array}$ \\
\hline \multicolumn{9}{|c|}{$\begin{array}{l}01198200 \text { - KONKAPOT RIVER AT ASHLEY FALLS, MA-Continued } \\
\text { WATER-QUALITY DATA, WATER YEAR OCTOBER } 1995 \text { TO SEPTEMBER 1996-Continued }\end{array}$} \\
\hline \multicolumn{9}{|c|}{ JAN-Continued } \\
\hline $25 \ldots$ & 1033 & 870 & 100 & -- & 0.0 & 68 & 160 & 50 \\
\hline $25 \ldots$ & 1630 & 763 & 98 & -- & .5 & 53 & 109 & -- \\
\hline $26 \ldots$ & 1345 & 342 & 153 & 1.5 & .5 & 40 & 37 & -- \\
\hline $25 \ldots$ & 1628 & 763 & 97 & -- & .5 & 62 & 128 & -- \\
\hline $26 \ldots$ & 1340 & 342 & 147 & 1.5 & .5 & 36 & 33 & -- \\
\hline $28 \ldots$ & 0928 & 1180 & 80 & -- & .0 & 40 & 127 & 61 \\
\hline $28 \ldots$ & 0930 & 1180 & 80 & -- & .0 & 43 & 137 & -- \\
\hline $28 \ldots$ & 1525 & 1040 & 82 & -- & 1.0 & 34 & 95 & -- \\
\hline $28 \ldots$ & 1526 & 1040 & 83 & -- & 1.0 & 25 & 70 & -- \\
\hline $29 \ldots$ & 1305 & 431 & 147 & -- & .0 & 36 & 42 & -- \\
\hline $29 \ldots$ & 1309 & 431 & 145 & -- & .0 & 36 & 42 & -- \\
\hline \multicolumn{9}{|l|}{ FEB } \\
\hline $10 \ldots$ & 1040 & 132 & 222 & 5.5 & 2.0 & 3 & 1.1 & -- \\
\hline $21 \ldots$ & 1434 & 244 & 191 & -- & 1.5 & 66 & 43 & -- \\
\hline $21 \ldots$ & 1436 & 244 & 185 & -- & 1.5 & 62 & 41 & -- \\
\hline $21 \ldots$ & 1715 & 276 & 178 & -- & 1.5 & 82 & 61 & -- \\
\hline $21 \ldots$ & 1717 & 279 & 178 & -- & 1.5 & 79 & 60 & -- \\
\hline $22 \ldots$ & 1230 & 487 & 127 & -- & 2.0 & 156 & 205 & -- \\
\hline $22 \ldots$ & 1232 & 487 & 127 & -- & 2.0 & 151 & 199 & -- \\
\hline $22 \ldots$ & 1648 & 559 & 112 & -- & 1.5 & 196 & 296 & -- \\
\hline $22 \ldots$ & 1650 & 559 & 109 & -- & 1.5 & 210 & 317 & -- \\
\hline $22 \ldots$ & 1655 & 559 & 109 & -- & 1.5 & 203 & 306 & -- \\
\hline $23 \ldots$ & 0951 & 475 & 108 & -- & 1.5 & 66 & 85 & -- \\
\hline $23 \ldots$ & 1345 & 418 & 112 & 11.0 & 2.0 & 69 & 78 & -- \\
\hline $23 \ldots$ & 1350 & 418 & 117 & 11.0 & 2.0 & 60 & 68 & -- \\
\hline $26 \ldots$ & 1110 & 244 & 156 & 6.0 & 2.0 & 27 & 18 & -- \\
\hline $26 \ldots$ & 1115 & 244 & 154 & 6.0 & 2.0 & 17 & 11 & -- \\
\hline \multicolumn{9}{|l|}{ MAR } \\
\hline $01 \ldots$ & 1350 & 157 & 189 & 0.5 & 1.5 & 12 & 5.1 & -- \\
\hline $01 \ldots$ & 1355 & 157 & 186 & 0.5 & 1.5 & 11 & 4.7 & -- \\
\hline $20 \ldots$ & 1228 & 274 & 161 & -- & 3.5 & 40 & 30 & -- \\
\hline $20 \ldots$ & 1625 & 282 & 160 & -- & 4.0 & 25 & 19 & -- \\
\hline $23 \ldots$ & 1235 & 177 & 183 & 2.0 & 2.0 & 9 & 4.3 & -- \\
\hline $29 \ldots$ & 1345 & 137 & 191 & 10.0 & 5.0 & 2 & .74 & -- \\
\hline $29 \ldots$ & 1350 & 137 & 190 & 10.0 & 5.0 & 2 & .74 & -- \\
\hline \multicolumn{9}{|l|}{ APR } \\
\hline $01 \ldots$ & 1437 & 119 & 191 & -- & 7.0 & 2 & .64 & -- \\
\hline $01 \ldots$ & 1440 & 119 & 190 & -- & 7.0 & 3 & .96 & -- \\
\hline $01 \ldots$ & 1444 & 119 & 187 & -- & 7.0 & 1 & .32 & -- \\
\hline $01 \ldots$ & 1446 & 119 & 189 & -- & 7.0 & 8 & 2.6 & -- \\
\hline $02 \ldots$ & 1114 & 244 & 165 & -- & 5.0 & 34 & 22 & -- \\
\hline $02 \ldots$ & 1120 & 244 & 164 & -- & 5.0 & 40 & 26 & -- \\
\hline $02 \ldots$ & 1140 & 246 & 162 & -- & 5.0 & 48 & 32 & -- \\
\hline $02 \ldots$ & 1142 & 246 & 161 & -- & 5.0 & 43 & 29 & -- \\
\hline
\end{tabular}

${ }^{1}$ Sediment, suspended, rounded to nearest whole number; associated sediment discharge, suspended, calculated using unrounded sediment, suspended. 
Appendix 3. Daily mean streamflow, daily mean suspended-sediment concentration, and daily total suspended-sediment discharge at three continuous-record sediment stations in the Housatonic River Basin, western Massachusetts, March 1994 through April 1996

[Source of data: Socolow and others, 1996; 1997. Locations shown in fig. 5 and described in table 2. CFS, cubic foot per second; MG/L, milligram per liter; TONS/DAY, tons per day; ---, not applicable]

01197500 HOUSATONIC RIVER NEAR GREAT BARRINGTON, MA

SUSPENDED-SEDIMENT DISCHARGE (TONS/DAY), WATER YEAR OCTOBER 1993 TO SEPTEMBER 1994

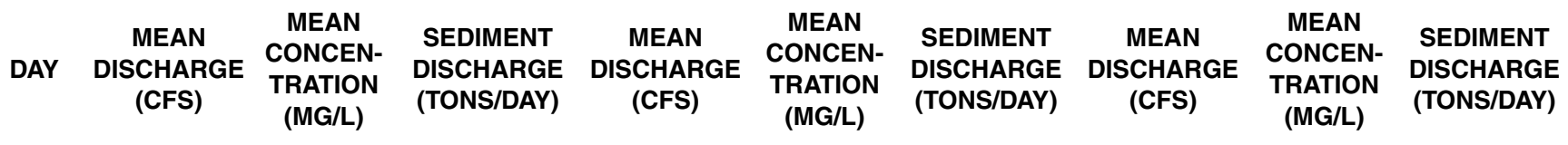

JANUARY

e340

344

333

319

e310

e310

308

305

e300

e300

e300

e300

304

288

e290

e290

e295

e310

e320

e320

e310

e295

e275

e270

e270

e270

e270

e310

e600

e700

e620

TOTAL 10376
FEBRUARY

---
---
---
---
---
---

e540

e470

e400

e 350

e320

e310

e300

e290

e290

e285

e280

e270

e265

e255

e250

e250

e260

e260

e260

e260

e 350

e520

e470

e435

e410

e 385

e 360

e340

---

$--$

9435

\begin{tabular}{|c|c|c|}
\hline --- & --- & e325 \\
\hline --- & --- & e315 \\
\hline --- & --- & e 310 \\
\hline --- & --- & e315 \\
\hline --- & --- & e 320 \\
\hline --- & --- & e330 \\
\hline--- & --- & 354 \\
\hline --- & --- & 501 \\
\hline --- & --- & 625 \\
\hline --- & --- & 974 \\
\hline --- & --- & 1540 \\
\hline --- & --- & 1350 \\
\hline --- & --- & 1120 \\
\hline --- & --- & 999 \\
\hline --- & --- & 984 \\
\hline --- & --- & 1070 \\
\hline --- & --- & 977 \\
\hline --- & --- & 899 \\
\hline --- & --- & 833 \\
\hline --- & --- & 751 \\
\hline --- & --- & 705 \\
\hline --- & --- & 911 \\
\hline --- & --- & 1110 \\
\hline --- & --- & 1340 \\
\hline --- & --- & 1530 \\
\hline --- & --- & 1520 \\
\hline--- & --- & 1420 \\
\hline --- & --- & 1560 \\
\hline --- & --- & 1730 \\
\hline --- & --- & 1610 \\
\hline-- & --- & 1400 \\
\hline & --- & 29728 \\
\hline
\end{tabular}

MARCH

\begin{tabular}{|c|c|c|}
\hline --- & & \\
\hline --- & & \\
\hline --- & & \\
\hline --- & & \\
\hline --- & & \\
\hline --- & & \\
\hline --- & & \\
\hline --- & & \\
\hline --- & & \\
\hline --- & & \\
\hline - & & \\
\hline - & & \\
\hline --- & & \\
\hline --- & & \\
\hline --- & & \\
\hline --- & & \\
\hline --- & & \\
\hline --- & & \\
\hline --- & & \\
\hline --- & & \\
\hline --- & & \\
\hline --- & & \\
\hline --- & & \\
\hline --- & & \\
\hline --- & & \\
\hline --- & & \\
\hline --- & & \\
\hline 8 & & \\
\hline 14 & & \\
\hline 6 & & \\
\hline 2 & & \\
\hline --- & & \\
\hline
\end{tabular}


Appendix 3. Daily mean streamflow, daily mean suspended-sediment concentration, and daily total suspended-sediment discharge at three continuous-record sediment stations in the Housatonic River Basin, western Massachusetts, March 1994 through April 1996-Continued

01197500 HOUSATONIC RIVER NEAR GREAT BARRINGTON, MA-Continued

\section{SUSPENDED-SEDIMENT DISCHARGE (TONS/DAY), WATER YEAR OCTOBER 1993 TO SEPTEMBER 1994}

\begin{tabular}{|c|c|c|c|c|c|c|c|c|c|}
\hline DAY & $\begin{array}{c}\text { MEAN } \\
\text { DISCHARGE } \\
\text { (CFS) }\end{array}$ & $\begin{array}{l}\text { MEAN } \\
\text { CONCEN- } \\
\text { TRATION } \\
\text { (MG/L) }\end{array}$ & $\begin{array}{l}\text { SEDIMENT } \\
\text { DISCHARGE } \\
\text { (TONS/DAY) }\end{array}$ & $\begin{array}{c}\text { MEAN } \\
\text { DISCHARGE } \\
\text { (CFS) }\end{array}$ & $\begin{array}{l}\text { MEAN } \\
\text { CONCEN- } \\
\text { TRATION } \\
\text { (MG/L) }\end{array}$ & $\begin{array}{l}\text { SEDIMENT } \\
\text { DISCHARGE } \\
\text { (TONS/DAY) }\end{array}$ & $\begin{array}{c}\text { MEAN } \\
\text { DISCHARGE } \\
\text { (CFS) }\end{array}$ & $\begin{array}{l}\text { MEAN } \\
\text { CONCEN- } \\
\text { TRATION } \\
\text { (MG/L) }\end{array}$ & $\begin{array}{c}\text { SEDIMENT } \\
\text { DISCHARGE } \\
\text { (TONS/DAY) }\end{array}$ \\
\hline & & APRIL & & & MAY & & & JUNE & \\
\hline 1 & 1410 & 2 & 7.6 & 733 & 7 & 13 & 317 & 10 & 8.2 \\
\hline 2 & 1510 & 3 & 12 & 955 & 11 & 29 & 292 & 10 & 7.8 \\
\hline 3 & 1590 & 3 & 13 & 817 & 8 & 19 & 275 & 9 & 6.9 \\
\hline 4 & 2120 & 7 & 44 & 678 & 7 & 12 & 257 & 9 & 6.1 \\
\hline 5 & 2340 & 10 & 62 & 585 & 6 & 9.6 & 237 & 8 & 5.3 \\
\hline 6 & 2410 & 19 & 125 & 530 & 6 & 8.6 & 218 & 8 & 4.5 \\
\hline 7 & 2830 & 36 & 285 & 514 & 6 & 8.3 & 251 & 7 & 4.9 \\
\hline 8 & 3280 & 32 & 282 & 699 & 8 & 15 & 262 & 7 & 4.8 \\
\hline 9 & 2850 & 18 & 140 & 950 & 13 & 34 & 235 & 6 & 4.0 \\
\hline 10 & 2400 & 15 & 98 & 830 & 10 & 23 & 197 & 6 & 3.2 \\
\hline 11 & 2670 & 22 & 159 & 669 & 6 & 11 & 189 & 6 & 2.8 \\
\hline 12 & 2920 & 29 & 230 & 626 & 5 & 9.0 & 208 & 5 & 2.9 \\
\hline 13 & 2730 & 25 & 185 & 703 & 6 & 12 & 259 & 5 & 3.3 \\
\hline 14 & 3550 & 33 & 321 & 634 & 5 & 8.3 & 250 & 4 & 2.9 \\
\hline 15 & 3840 & 25 & 260 & 540 & 3 & 4.2 & 266 & 4 & 3.0 \\
\hline 16 & 3300 & 15 & 137 & 802 & 6 & 15 & 240 & 5 & 3.0 \\
\hline 17 & 3400 & 17 & 156 & 1400 & 12 & 46 & 213 & 6 & 3.2 \\
\hline 18 & 3030 & 15 & 122 & 1350 & 8 & 29 & 214 & 7 & 3.8 \\
\hline 19 & 2360 & 13 & 82 & 1040 & 5 & 13 & 223 & 8 & 4.7 \\
\hline 20 & 1950 & 11 & 57 & 879 & 4 & 10 & 174 & 9 & 4.4 \\
\hline 21 & 1550 & 9 & 37 & 754 & 5 & 9.4 & 161 & 11 & 4.8 \\
\hline 22 & 1200 & 8 & 25 & 644 & 5 & 8.7 & 164 & 13 & 5.6 \\
\hline 23 & 986 & 7 & 18 & 575 & 5 & 8.4 & 160 & 12 & 5.0 \\
\hline 24 & 851 & 6 & 14 & 531 & 6 & 8.4 & 149 & 10 & 4.2 \\
\hline 25 & 776 & 6 & 12 & 493 & 6 & 8.4 & 155 & 9 & 3.9 \\
\hline 26 & 698 & 5 & 10 & 525 & 7 & 9.7 & 159 & 8 & 3.6 \\
\hline 27 & 655 & 5 & 9.1 & 507 & 7 & 10 & 151 & 7 & 3.0 \\
\hline 28 & 726 & 5 & 9.8 & 455 & 8 & 9.8 & 145 & 7 & 2.6 \\
\hline 29 & 697 & 5 & 9.4 & 407 & 8 & 9.2 & 209 & 7 & 4.8 \\
\hline 30 & 633 & 5 & 8.5 & 366 & 9 & 8.7 & 408 & 8 & 9.1 \\
\hline 31 & --- & --- & --- & 325 & 9 & 8.0 & --- & --- & --- \\
\hline ГОТАL & 61262 & --- & 2930.4 & 21516 & --- & 427.7 & 6638 & --- & 136.3 \\
\hline
\end{tabular}


Appendix 3. Daily mean streamflow, daily mean suspended-sediment concentration, and daily total suspended-sediment discharge at three continuous-record sediment stations in the Housatonic River Basin, western Massachusetts, March 1994 through April 1996-Continued

01197500 HOUSATONIC RIVER NEAR GREAT BARRINGTON, MA-Continued

\section{SUSPENDED-SEDIMENT DISCHARGE (TONS/DAY), WATER YEAR OCTOBER 1993 TO SEPTEMBER 1994}

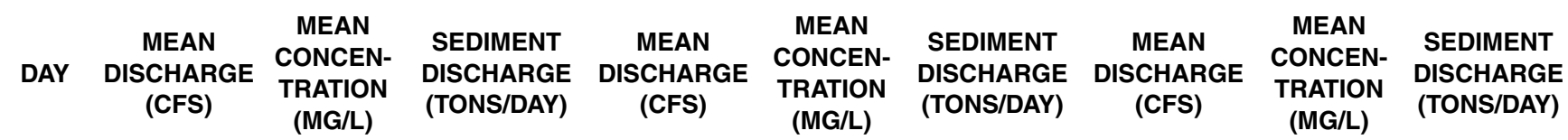

JULY

AUGUST

SEPTEMBER

\begin{tabular}{|c|c|c|c|c|c|c|c|c|c|}
\hline 1 & 320 & 6 & 5.6 & 205 & 6 & 3.3 & 246 & 8 & 5.3 \\
\hline 2 & 239 & 5 & 3.5 & 159 & 6 & 2.6 & 161 & 7 & 3.1 \\
\hline 3 & 182 & 5 & 2.3 & 151 & 6 & 2.4 & 146 & 6 & 2.5 \\
\hline 4 & 148 & 4 & 1.7 & 151 & 6 & 2.4 & 135 & 5 & 2.0 \\
\hline 5 & 126 & 4 & 1.3 & 144 & 6 & 2.3 & 127 & 5 & 1.6 \\
\hline 6 & 121 & 3 & 1.1 & 151 & 6 & 2.4 & 119 & 4 & 1.3 \\
\hline 7 & 120 & 3 & .99 & 137 & 6 & 2.2 & 115 & 4 & 1.2 \\
\hline 8 & 130 & 3 & 1.1 & 123 & 6 & 2.0 & 114 & 4 & 1.2 \\
\hline 9 & 155 & 3 & 1.4 & 109 & 6 & 1.8 & 113 & 4 & 1.1 \\
\hline 10 & 140 & 4 & 1.4 & 108 & 6 & 1.7 & 118 & 4 & 1.1 \\
\hline 11 & 125 & 4 & 1.3 & 103 & 6 & 1.7 & 114 & 3 & 1.1 \\
\hline 12 & 113 & 4 & 1.3 & 98 & 6 & 1.6 & 109 & 3 & .97 \\
\hline 13 & 110 & 4 & 1.3 & 98 & 6 & 1.6 & 110 & 3 & .95 \\
\hline 14 & 104 & 5 & 1.3 & 167 & 7 & 3.3 & 120 & 3 & 1.0 \\
\hline 15 & 101 & 5 & 1.4 & 213 & 11 & 6.2 & 117 & 3 & .96 \\
\hline 16 & 103 & 5 & 1.4 & 168 & 12 & 5.3 & 108 & 3 & .99 \\
\hline 17 & 98 & 5 & 1.3 & 144 & 11 & 4.3 & 106 & 4 & 1.1 \\
\hline 18 & 103 & 5 & 1.4 & 243 & 13 & 9.2 & 119 & 4 & 1.4 \\
\hline 19 & 118 & 5 & 1.6 & 413 & 15 & 17 & 115 & 5 & 1.5 \\
\hline 20 & 114 & 5 & 1.5 & 353 & 11 & 11 & 105 & 5 & 1.5 \\
\hline 21 & 182 & 6 & 3.2 & 283 & 10 & 7.8 & 101 & 6 & 1.6 \\
\hline 22 & 180 & 7 & 3.4 & 728 & 14 & 29 & 100 & 6 & 1.6 \\
\hline 23 & 408 & 10 & 12 & 815 & 13 & 28 & 132 & 6 & 2.2 \\
\hline 24 & 538 & 12 & 18 & 531 & 13 & 18 & 181 & 7 & 3.6 \\
\hline 25 & 367 & 11 & 11 & 376 & 10 & 10 & 174 & 7 & 3.4 \\
\hline 26 & 254 & 10 & 6.9 & 300 & 9 & 7.4 & 152 & 6 & 2.5 \\
\hline 27 & 292 & 10 & 7.9 & 260 & 8 & 5.9 & 203 & 6 & 3.5 \\
\hline 28 & 320 & 10 & 8.9 & 223 & 8 & 4.8 & 665 & 12 & 23 \\
\hline 29 & 356 & 11 & 11 & 231 & 8 & 5.0 & 740 & 13 & 27 \\
\hline 30 & 284 & 9 & 6.8 & 237 & 8 & 5.1 & 490 & 9 & 12 \\
\hline 31 & 236 & 7 & 4.4 & 271 & 8 & 5.9 & --- & --- & --- \\
\hline TOTAL & 6187 & --- & 127.69 & 7693 & --- & 211.2 & 5455 & --- & 112.27 \\
\hline
\end{tabular}


Appendix 3. Daily mean streamflow, daily mean suspended-sediment concentration, and daily total suspended-sediment discharge at three continuous-record sediment stations in the Housatonic River Basin, western Massachusetts, March 1994 through April 1996-Continued

01197500 HOUSATONIC RIVER NEAR GREAT BARRINGTON, MA-Continued

\section{SUSPENDED-SEDIMENT DISCHARGE (TONS/DAY), WATER YEAR OCTOBER 1994 TO SEPTEMBER 1995}

\begin{tabular}{|c|c|c|c|c|c|c|c|c|c|}
\hline$A$ & $\begin{array}{c}\text { MEAN } \\
\text { DISCHARGE } \\
\text { (CFS) }\end{array}$ & $\begin{array}{l}\text { MEAN } \\
\text { CONCEN- } \\
\text { TRATION } \\
\text { (MG/L) }\end{array}$ & $\begin{array}{l}\text { SEDIMENT } \\
\text { DISCHARGE } \\
\text { (TONS/DAY) }\end{array}$ & $\begin{array}{c}\text { MEAN } \\
\text { DISCHARGE } \\
\text { (CFS) }\end{array}$ & $\begin{array}{c}\text { MEAN } \\
\text { CONCEN- } \\
\text { TRATION } \\
\text { (MG/L) }\end{array}$ & $\begin{array}{l}\text { SEDIMENT } \\
\text { DISCHARGE } \\
\text { (TONS/DAY) }\end{array}$ & $\begin{array}{c}\text { MEAN } \\
\text { DISCHARGE } \\
\text { (CFS) }\end{array}$ & $\begin{array}{c}\text { MEAN } \\
\text { CONCEN- } \\
\text { TRATION } \\
\text { (MG/L) }\end{array}$ & $\begin{array}{c}\text { SEDIMENT } \\
\text { DISCHARGE } \\
\text { (TONS/DAY) }\end{array}$ \\
\hline
\end{tabular}

OCTOBER

\begin{tabular}{|c|c|}
\hline 1 & 332 \\
\hline 2 & 277 \\
\hline 3 & 270 \\
\hline 4 & 250 \\
\hline 5 & 247 \\
\hline 6 & 262 \\
\hline 7 & 256 \\
\hline 8 & 244 \\
\hline 9 & 245 \\
\hline 10 & 272 \\
\hline 11 & 259 \\
\hline 12 & 231 \\
\hline 13 & 213 \\
\hline 14 & 198 \\
\hline 15 & 188 \\
\hline 16 & 174 \\
\hline 17 & 162 \\
\hline 18 & 174 \\
\hline 19 & 197 \\
\hline 20 & 208 \\
\hline 21 & 251 \\
\hline 22 & 254 \\
\hline 23 & 237 \\
\hline 24 & 250 \\
\hline 25 & 248 \\
\hline 26 & 256 \\
\hline 27 & 246 \\
\hline 28 & 232 \\
\hline 29 & 223 \\
\hline 30 & 212 \\
\hline 31 & 206 \\
\hline
\end{tabular}

NOVEMBER

$\begin{array}{ll}7.1 & 213 \\ 4.4 & 244 \\ 2.6 & 262 \\ 1.6 & 229\end{array}$

1.5205

$1.8 \quad 191$

$1.9 \quad 203$

1.9200

$2.0 \quad 192$

$1.7 \quad 185$

$1.3 \quad 184$

$.88 \quad 189$

$.64 \quad 189$

$.57 \quad 173$

$\begin{array}{ll}.53 & 169\end{array}$

$.50 \quad 171$

$.46 \quad 175$

$.50 \quad 182$

$.62 \quad 187$

$1.2 \quad 184$

$2.6 \quad 190$

$2.6 \quad 335$

$2.1 \quad 357$

$2.0 \quad 293$

$1.7 \quad 244$

$1.6 \quad 234$

$1.3 \quad 217$

$1.1 \quad 327$

$.94 \quad 689$

$.79 \quad 632$

.67

51.10

$\begin{array}{ll}0.69 & 501 \\ 1.2 & 408 \\ .79 & 367 \\ .66 & 346\end{array}$

DECEMBER

1.2

$\begin{array}{lc}1 & 0.69 \\ 2 & 1.2 \\ 1 & .79 \\ 1 & .66 \\ 1 & .59\end{array}$

496

$.54 \quad 1100$

$.58 \quad 1040$

$\begin{array}{ll}.57 & 768\end{array}$

$.55 \quad 603$

$.53 \quad 540$

$.52 \quad 641$

$.54 \quad 641$

$.54 \quad 532$

$.49 \quad 480$

.48

441

425

437

444

440

394

377

381

352

740

1490

1260

810

648

585

426

474

4.8
---

40.51

18587

$\begin{array}{rc}1 & 1.2 \\ 1 & .79 \\ 1 & .60 \\ \mathrm{a} 0 & .48 \\ 1 & 2.5 \\ 9 & 26 \\ 3 & 9.5 \\ 2 & 4.8 \\ 2 & 3.3 \\ 2 & 2.9 \\ 2 & 4.1 \\ 3 & 5.9 \\ 2 & 2.9 \\ 2 & 2.6 \\ 2 & 2.5 \\ 2 & 2.9 \\ 3 & 3.8 \\ 4 & 4.6 \\ 3 & 3.8 \\ 3 & 2.7 \\ 2 & 2.1 \\ 2 & 2.1 \\ 2 & 2.0 \\ 6 & 15 \\ 17 & 68 \\ 12 & 41 \\ 5 & 11 \\ 3 & 5.6 \\ 3 & 4.7 \\ 3 & 3.5 \\ 3 & 3.8 \\ --- & 246.67\end{array}$


Appendix 3. Daily mean streamflow, daily mean suspended-sediment concentration, and daily total suspended-sediment discharge at three continuous-record sediment stations in the Housatonic River Basin, western Massachusetts, March 1994 through April 1996-Continued

01197500 HOUSATONIC RIVER NEAR GREAT BARRINGTON, MA-Continued

\section{SUSPENDED-SEDIMENT DISCHARGE (TONS/DAY), WATER YEAR OCTOBER 1994 TO SEPTEMBER 1995}

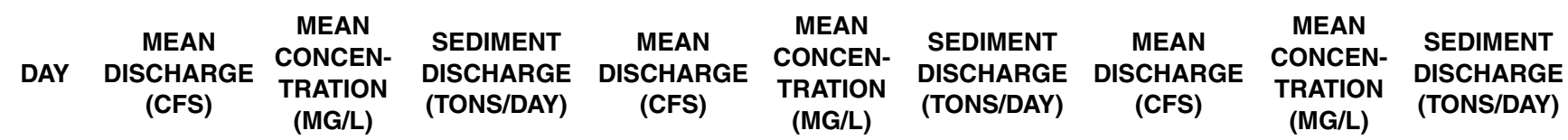

JANUARY

FEBRUARY

MARCH

\begin{tabular}{|c|c|c|c|c|c|c|c|c|c|}
\hline 1 & 653 & 3 & 5.8 & 492 & 2 & 2.5 & 603 & 6 & 9.3 \\
\hline 2 & 911 & 7 & 17 & 482 & 2 & 2.3 & 510 & 3 & 4.0 \\
\hline 3 & 775 & 6 & 13 & 424 & 2 & 1.9 & 422 & 2 & 2.3 \\
\hline 4 & 616 & 3 & 5.4 & 409 & 1 & 1.7 & 368 & 2 & 2.0 \\
\hline 5 & 578 & 3 & 3.9 & 379 & 1 & 1.4 & 338 & 2 & 1.9 \\
\hline 6 & 565 & 3 & 3.3 & 408 & 1 & .97 & 377 & 2 & 2.2 \\
\hline 7 & 615 & 5 & 7.9 & 412 & 1 & .92 & 449 & 3 & 3.8 \\
\hline 8 & 806 & 7 & 15 & 373 & 1 & .89 & 887 & 6 & 20 \\
\hline 9 & 686 & 4 & 6.7 & 348 & 1 & .86 & 2610 & 34 & 242 \\
\hline 10 & 545 & 3 & 4.4 & 313 & 1 & .84 & 2450 & 21 & 138 \\
\hline 11 & 537 & 3 & 3.7 & 235 & 1 & .84 & 1690 & 11 & 52 \\
\hline 12 & 442 & 3 & 3.6 & 240 & 1 & .81 & 1170 & 6 & 20 \\
\hline 13 & 537 & 3 & 4.5 & 293 & 1 & .81 & 1020 & 4 & 12 \\
\hline 14 & 717 & 4 & 8.7 & 363 & 1 & .78 & 1100 & 5 & 14 \\
\hline 15 & 1050 & 9 & 25 & 344 & 1 & .78 & 1190 & 5 & 17 \\
\hline 16 & 1330 & 13 & 45 & 295 & 1 & .90 & 1260 & 6 & 20 \\
\hline 17 & 1430 & 13 & 51 & 322 & 2 & 1.6 & 1300 & 7 & 26 \\
\hline 18 & 1340 & 10 & 36 & 341 & 3 & 2.4 & 1240 & 7 & 22 \\
\hline 19 & 1080 & 5 & 16 & 298 & 2 & 1.6 & 1090 & 5 & 15 \\
\hline 20 & 988 & 4 & 12 & 279 & 1 & 1.1 & 927 & 4 & 9.8 \\
\hline 21 & 1450 & 13 & 52 & 291 & 1 & .89 & 864 & 3 & 7.8 \\
\hline 22 & 1750 & 14 & 64 & 279 & 1 & 1.0 & 943 & 5 & 13 \\
\hline 23 & 1480 & 6 & 23 & 271 & 2 & 1.2 & 899 & 6 & 14 \\
\hline 24 & 1140 & 6 & 17 & 376 & 2 & 2.0 & 785 & 5 & 9.7 \\
\hline 25 & 945 & 6 & 16 & 416 & 2 & 1.9 & 662 & 4 & 7.2 \\
\hline 26 & 798 & 7 & 14 & 339 & 1 & 1.3 & 576 & 4 & 6.2 \\
\hline 27 & 716 & 5 & 11 & 295 & 1 & .99 & 516 & 4 & 5.6 \\
\hline 28 & 645 & 5 & 8.0 & 386 & 2 & 2.3 & 464 & 4 & 5.0 \\
\hline 29 & 691 & 4 & 5.9 & --- & --- & --- & 432 & 4 & 4.7 \\
\hline 30 & 621 & 3 & 4.1 & --- & --- & --- & 406 & 4 & 4.4 \\
\hline 31 & 510 & 2 & 2.9 & --- & --- & --- & 451 & 4 & 4.7 \\
\hline ГOTAL & 26947 & --- & 505.8 & 9703 & --- & 37.48 & 27999 & --- & 715.6 \\
\hline
\end{tabular}


Appendix 3. Daily mean streamflow, daily mean suspended-sediment concentration, and daily total suspended-sediment discharge at three continuous-record sediment stations in the Housatonic River Basin, western Massachusetts, March 1994 through April 1996-Continued

01197500 HOUSATONIC RIVER NEAR GREAT BARRINGTON, MA-Continued

\section{SUSPENDED-SEDIMENT DISCHARGE (TONS/DAY), WATER YEAR OCTOBER 1994 TO SEPTEMBER 1995}

\begin{tabular}{|c|c|c|c|c|c|c|c|c|c|}
\hline DAY & $\begin{array}{c}\text { MEAN } \\
\text { DISCHARGE } \\
\text { (CFS) }\end{array}$ & $\begin{array}{l}\text { MEAN } \\
\text { CONCEN- } \\
\text { TRATION } \\
\text { (MG/L) }\end{array}$ & $\begin{array}{l}\text { SEDIMENT } \\
\text { DISCHARGE } \\
\text { (TONS/DAY) }\end{array}$ & $\begin{array}{l}\text { MEAN } \\
\text { DISCHARGE } \\
\text { (CFS) }\end{array}$ & $\begin{array}{l}\text { MEAN } \\
\text { CONCEN- } \\
\text { TRATION } \\
\text { (MG/L) }\end{array}$ & $\begin{array}{l}\text { SEDIMENT } \\
\text { DISCHARGE } \\
\text { (TONS/DAY) }\end{array}$ & $\begin{array}{c}\text { MEAN } \\
\text { DISCHARGE } \\
\text { (CFS) }\end{array}$ & $\begin{array}{l}\text { MEAN } \\
\text { CONCEN- } \\
\text { TRATION } \\
\text { (MG/L) }\end{array}$ & $\begin{array}{c}\text { SEDIMENT } \\
\text { DISCHARGE } \\
\text { (TONS/DAY) }\end{array}$ \\
\hline & & APRIL & & & MAY & & & JUNE & \\
\hline 1 & 438 & 3 & 3.8 & 358 & 5 & 5.1 & 209 & 7 & 3.6 \\
\hline 2 & 397 & 3 & 2.7 & 347 & 6 & 5.4 & 184 & 5 & 2.5 \\
\hline 3 & 360 & 2 & 2.0 & 335 & 6 & 5.6 & 209 & 6 & 3.0 \\
\hline 4 & 368 & 2 & 2.2 & 321 & 7 & 5.7 & 433 & 10 & 12 \\
\hline 5 & 429 & 2 & 2.8 & 312 & 7 & 5.6 & 501 & 10 & 13 \\
\hline 6 & 376 & 3 & 2.7 & 370 & 7 & 6.8 & 397 & 8 & 9.1 \\
\hline 7 & 341 & 3 & 2.7 & 359 & 7 & 6.6 & 289 & 6 & 4.5 \\
\hline 8 & 329 & 3 & 2.8 & 314 & 7 & 5.7 & 231 & 5 & 2.9 \\
\hline 9 & 332 & 3 & 3.0 & 284 & 7 & 5.1 & 198 & 5 & 2.5 \\
\hline 10 & 374 & 4 & 3.6 & 274 & 7 & 4.8 & 180 & 5 & 2.3 \\
\hline 11 & 371 & 4 & 3.8 & 298 & 6 & 4.8 & 166 & 5 & 2.1 \\
\hline 12 & 339 & 4 & 3.8 & 353 & 6 & 5.2 & 175 & 5 & 2.2 \\
\hline 13 & 583 & 7 & 11 & 348 & 5 & 4.7 & 216 & 5 & 2.8 \\
\hline 14 & 799 & 6 & 12 & 298 & 5 & 4.2 & 201 & 7 & 3.4 \\
\hline 15 & 653 & 4 & 7.2 & 290 & 6 & 4.5 & 186 & 7 & 3.2 \\
\hline 16 & 500 & 3 & 4.6 & 316 & 7 & 5.4 & 166 & 7 & 2.8 \\
\hline 17 & 431 & 2 & 2.6 & 302 & 7 & 5.7 & 156 & 6 & 2.6 \\
\hline 18 & 393 & 2 & 2.1 & 290 & 8 & 5.9 & 141 & 6 & 2.3 \\
\hline 19 & 471 & 4 & 6.2 & 280 & 8 & 5.7 & 128 & 6 & 2.0 \\
\hline 20 & 690 & 10 & 19 & 285 & 8 & 5.9 & 129 & 6 & 2.0 \\
\hline 21 & 615 & 9 & 15 & 265 & 8 & 5.4 & 124 & 6 & 2.0 \\
\hline 22 & 596 & 8 & 12 & 248 & 8 & 5.0 & 124 & 7 & 2.0 \\
\hline 23 & 542 & 5 & 7.8 & 232 & 8 & 4.7 & 125 & 7 & 2.2 \\
\hline 24 & 468 & 5 & 6.3 & 214 & 8 & 4.4 & 113 & 7 & 2.0 \\
\hline 25 & 430 & 5 & 5.7 & 262 & 8 & 5.5 & 108 & 7 & 2.0 \\
\hline 26 & 394 & 5 & 5.2 & 265 & 10 & 6.5 & 124 & 8 & 2.4 \\
\hline 27 & 370 & 5 & 4.9 & 240 & 9 & 5.6 & 133 & 8 & 2.7 \\
\hline 28 & 378 & 5 & 5.0 & 214 & 9 & 4.7 & 119 & 7 & 2.1 \\
\hline 29 & 412 & 5 & 5.5 & 207 & 8 & 4.4 & 108 & 6 & 1.7 \\
\hline 30 & 379 & 5 & 5.0 & 280 & 10 & 7.5 & 101 & 6 & 1.5 \\
\hline 31 & --- & --- & --- & 251 & 9 & 5.8 & --- & --- & --- \\
\hline ГОТАL & 13558 & --- & 173.0 & 9012 & --- & 167.9 & 5674 & --- & 101.4 \\
\hline
\end{tabular}


Appendix 3. Daily mean streamflow, daily mean suspended-sediment concentration, and daily total suspended-sediment discharge at three continuous-record sediment stations in the Housatonic River Basin, western Massachusetts, March 1994 through April 1996-Continued

01197500 HOUSATONIC RIVER NEAR GREAT BARRINGTON, MA-Continued

\section{SUSPENDED-SEDIMENT DISCHARGE (TONS/DAY), WATER YEAR OCTOBER 1994 TO SEPTEMBER 1995}

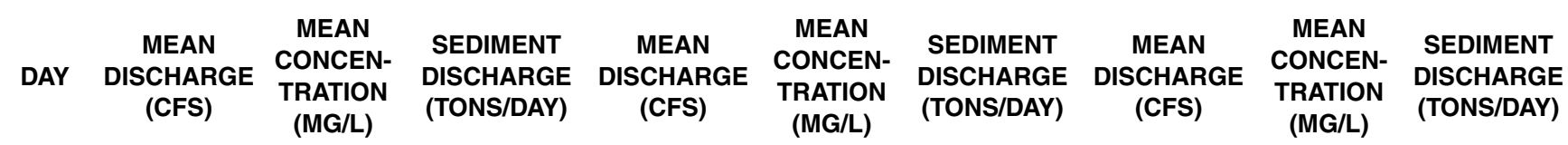

JULY

\begin{tabular}{|c|c|c|c|c|c|c|c|c|c|}
\hline 1 & 103 & 6 & 1.6 & 87 & 6 & 1.4 & 62 & 6 & 0.98 \\
\hline 2 & 201 & 13 & 6.9 & 82 & 6 & 1.3 & 74 & 5 & .95 \\
\hline 3 & 162 & 13 & 5.4 & 79 & 5 & 1.1 & 64 & 4 & .63 \\
\hline 4 & 125 & 11 & 3.6 & 97 & 5 & 1.5 & 57 & 3 & .42 \\
\hline 5 & 106 & 11 & 2.9 & 221 & 8 & 5.1 & 54 & 2 & .31 \\
\hline 6 & 97 & 11 & 2.6 & 290 & 11 & 8.8 & 52 & 3 & .37 \\
\hline 7 & 99 & 11 & 2.7 & 338 & 14 & 13 & 54 & 4 & .53 \\
\hline 8 & 108 & 11 & 3.0 & 213 & 7 & 4.2 & 54 & 5 & .68 \\
\hline 9 & 104 & 10 & 2.7 & 152 & 5 & 2.1 & 58 & 4 & .62 \\
\hline 10 & 99 & 10 & 2.4 & 112 & 3 & 1.0 & 66 & 3 & .57 \\
\hline 11 & 94 & 9 & 2.1 & 105 & 2 & .61 & 62 & 3 & .50 \\
\hline 12 & 206 & 11 & 6.0 & 94 & 2 & .59 & 55 & 3 & .44 \\
\hline 13 & 174 & 10 & 4.4 & 90 & 3 & .64 & 59 & 3 & .47 \\
\hline 14 & 131 & 6 & 2.1 & 82 & 3 & .68 & 76 & 2 & .44 \\
\hline 15 & 115 & 5 & 1.4 & 79 & 4 & .81 & 72 & 2 & .41 \\
\hline 16 & 123 & 4 & 1.3 & 78 & 5 & 1.0 & 65 & 2 & .39 \\
\hline 17 & 122 & 4 & 1.3 & 77 & 6 & 1.2 & 77 & 2 & .49 \\
\hline 18 & 108 & 4 & 1.2 & 75 & 5 & 1.1 & 109 & 3 & .74 \\
\hline 19 & 110 & 5 & 1.3 & 70 & 5 & .86 & 90 & 3 & .64 \\
\hline 20 & 109 & 5 & 1.3 & 66 & 4 & .74 & 77 & 3 & .58 \\
\hline 21 & 100 & 5 & 1.2 & 61 & 4 & .74 & 73 & 3 & .59 \\
\hline 22 & 96 & 5 & 1.2 & 58 & 5 & .79 & 80 & 3 & .65 \\
\hline 23 & 92 & 5 & 1.1 & 57 & 6 & .86 & 171 & 5 & 2.6 \\
\hline 24 & 98 & 5 & 1.2 & 57 & 6 & .97 & 150 & 4 & 1.5 \\
\hline 25 & 125 & 5 & 1.7 & 56 & 7 & 1.0 & 112 & 2 & .64 \\
\hline 26 & 134 & 6 & 2.1 & 54 & 7 & 1.0 & 105 & 2 & .45 \\
\hline 27 & 142 & 6 & 2.3 & 56 & 7 & 1.0 & 107 & 1 & .36 \\
\hline 28 & 135 & 6 & 2.6 & 57 & 7 & 1.0 & 101 & 1 & .28 \\
\hline 29 & 130 & 7 & 2.2 & 59 & 6 & 1.0 & 95 & 1 & .26 \\
\hline 30 & 136 & 7 & 2.4 & 57 & 6 & .96 & 88 & 1 & .24 \\
\hline 31 & 111 & 7 & 1.8 & 55 & 6 & .91 & --- & --- & --- \\
\hline TOTAL & 3795 & --- & 76.0 & 3114 & --- & 57.96 & 2419 & --- & 18.73 \\
\hline YEAR & 135527 & & 2192.15 & & & & & & \\
\hline
\end{tabular}


Appendix 3. Daily mean streamflow, daily mean suspended-sediment concentration, and daily total suspended-sediment discharge at three continuous-record sediment stations in the Housatonic River Basin, western Massachusetts, March 1994 through April 1996-Continued

01197500 HOUSATONIC RIVER NEAR GREAT BARRINGTON, MA-Continued SEDIMENT DISCHARGE, SUSPENDED (TONS/DAY), WATER YEAR OCTOBER 1995 TO SEPTEMBER 1996

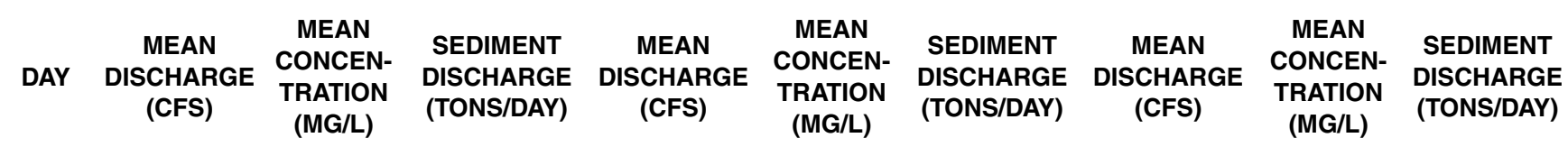

OCTOBER

\begin{tabular}{|c|c|c|c|c|c|c|c|c|c|}
\hline 1 & 86 & 2 & 0.46 & 788 & 11 & 24 & 518 & 2 & 2.9 \\
\hline 2 & 93 & 2 & .50 & 741 & 9 & 19 & 518 & 2 & 2.9 \\
\hline 3 & 98 & 2 & .53 & 882 & 9 & 21 & 486 & 2 & 2.8 \\
\hline 4 & 128 & 2 & .69 & 805 & 8 & 18 & 503 & 2 & 3.0 \\
\hline 5 & 218 & 2 & 1.4 & 649 & 8 & 14 & 508 & 2 & 3.1 \\
\hline 6 & 574 & 14 & 21 & 539 & 7 & 11 & 498 & 2 & 3.1 \\
\hline 7 & 697 & 11 & 20 & 516 & 7 & 9.7 & 477 & 2 & 3.1 \\
\hline 8 & 508 & 8 & 11 & 621 & 6 & 9.7 & 427 & 2 & 2.8 \\
\hline 9 & 351 & 6 & 6.1 & 600 & 5 & 7.6 & e400 & 3 & 3.2 \\
\hline 10 & 257 & 5 & 3.6 & 530 & 4 & 5.3 & e370 & 3 & 3.0 \\
\hline 11 & 223 & 4 & 2.5 & 529 & 3 & 4.4 & e350 & 3 & 2.8 \\
\hline 12 & 194 & 4 & 2.1 & 1420 & 21 & 98 & e340 & 3 & 2.8 \\
\hline 13 & 166 & 4 & 1.8 & 2290 & 27 & 168 & e330 & 3 & 2.7 \\
\hline 14 & 168 & 4 & 1.8 & 2100 & 19 & 107 & e330 & 3 & 2.7 \\
\hline 15 & 433 & 5 & 6.4 & 1890 & 12 & 63 & e340 & 3 & 2.8 \\
\hline 16 & 473 & 4 & 4.9 & 1860 & 11 & 53 & e360 & 3 & 2.9 \\
\hline 17 & 349 & 4 & 3.4 & 1610 & 9 & 40 & e350 & 3 & 2.8 \\
\hline 18 & 239 & 3 & 2.1 & 1280 & 8 & 28 & e340 & 3 & 2.8 \\
\hline 19 & 215 & 3 & 1.8 & 1100 & 8 & 24 & e340 & 3 & 2.8 \\
\hline 20 & 197 & 3 & 1.6 & 1050 & 8 & 23 & e340 & 3 & 2.8 \\
\hline 21 & 299 & 8 & 10 & 961 & 8 & 21 & e330 & 3 & 2.7 \\
\hline 22 & 1590 & 31 & 136 & 866 & 9 & 20 & e320 & 3 & 2.6 \\
\hline 23 & 1890 & 38 & 200 & 718 & 9 & 17 & e315 & 3 & 2.6 \\
\hline 24 & 1150 & 9 & 31 & 624 & 9 & 15 & e310 & 4 & 3.3 \\
\hline 25 & 706 & 5 & 10 & 559 & 9 & 14 & e300 & 4 & 3.2 \\
\hline 26 & 573 & 4 & 6.3 & 523 & 10 & 14 & e295 & 4 & 3.2 \\
\hline 27 & 511 & 4 & 5.5 & 514 & 10 & 13 & e290 & 4 & 3.1 \\
\hline 28 & 1280 & 18 & 82 & 483 & 6 & 8.1 & e290 & 4 & 3.1 \\
\hline 29 & 2300 & 32 & 200 & 517 & 4 & 5.1 & $\mathrm{e} 280$ & 4 & 3.0 \\
\hline 30 & 1800 & 17 & 85 & 542 & 2 & 3.2 & e260 & 4 & 2.8 \\
\hline 31 & 1110 & 14 & 42 & --- & --- & --- & $\mathrm{e} 245$ & 4 & 2.6 \\
\hline OTAL & 18876 & --- & 901.48 & 28107 & --- & 878.1 & 11360 & --- & 90.0 \\
\hline
\end{tabular}


Appendix 3. Daily mean streamflow, daily mean suspended-sediment concentration, and daily total suspended-sediment discharge at three continuous-record sediment stations in the Housatonic River Basin, western Massachusetts, March 1994 through April 1996-Continued

01197500 HOUSATONIC RIVER NEAR GREAT BARRINGTON, MA-Continued SEDIMENT DISCHARGE, SUSPENDED (TONS/DAY), WATER YEAR OCTOBER 1995 TO SEPTEMBER 1996

\begin{tabular}{|c|c|c|c|c|c|c|c|c|c|}
\hline DAY & $\begin{array}{c}\text { MEAN } \\
\text { DISCHARGE } \\
\text { (CFS) }\end{array}$ & $\begin{array}{l}\text { MEAN } \\
\text { CONCEN- } \\
\text { TRATION } \\
\text { (MG/L) }\end{array}$ & $\begin{array}{l}\text { SEDIMENT } \\
\text { DISCHARGE } \\
\text { (TONS/DAY) }\end{array}$ & $\begin{array}{c}\text { MEAN } \\
\text { DISCHARGE } \\
\text { (CFS) }\end{array}$ & $\begin{array}{c}\text { MEAN } \\
\text { CONCEN- } \\
\text { TRATION } \\
\text { (MG/L) }\end{array}$ & $\begin{array}{l}\text { SEDIMENT } \\
\text { DISCHARGE } \\
\text { (TONS/DAY) }\end{array}$ & $\begin{array}{c}\text { MEAN } \\
\text { DISCHARGE } \\
\text { (CFS) }\end{array}$ & $\begin{array}{l}\text { MEAN } \\
\text { CONCEN- } \\
\text { TRATION } \\
\text { (MG/L) }\end{array}$ & $\begin{array}{l}\text { SEDIMENT } \\
\text { DISCHARGE } \\
\text { (TONS/DAY) }\end{array}$ \\
\hline & & JANUARY & & & FEBRUARY & & & MARCH & \\
\hline 1 & 240 & 4 & 2.3 & 1380 & 3 & 10 & 1070 & 4 & 11 \\
\hline 2 & 242 & 3 & 2.2 & 1130 & 2 & 6.1 & 926 & 4 & 9.3 \\
\hline 3 & $\mathrm{e} 240$ & 3 & 1.9 & e950 & 2 & 5.1 & 803 & 4 & 7.9 \\
\hline 4 & $\mathrm{e} 250$ & 3 & 2.0 & e850 & 2 & 4.6 & 716 & 4 & 6.9 \\
\hline 5 & $\mathrm{e} 245$ & 3 & 2.0 & e750 & 2 & 4.0 & 684 & 4 & 6.5 \\
\hline 6 & $\mathrm{e} 245$ & 3 & 2.0 & e700 & 2 & 3.8 & 796 & 3 & 7.4 \\
\hline 7 & $\mathrm{e} 250$ & 3 & 2.0 & e650 & 2 & 3.5 & 806 & 3 & 7.3 \\
\hline 8 & e260 & 3 & 2.1 & e600 & 2 & 3.2 & 741 & 3 & 6.6 \\
\hline 9 & $\mathrm{e} 250$ & 3 & 2.0 & e570 & 2 & 3.1 & 701 & 3 & 6.1 \\
\hline 10 & $\mathrm{e} 250$ & 3 & 2.0 & e530 & 2 & 2.9 & e710 & 3 & 5.8 \\
\hline 11 & e260 & 3 & 2.1 & e500 & 2 & 2.7 & e650 & 3 & 5.3 \\
\hline 12 & $\mathrm{e} 250$ & 3 & 2.0 & $\mathrm{e} 470$ & 2 & 2.5 & 615 & 3 & 5.1 \\
\hline 13 & $\mathrm{e} 250$ & 3 & 2.0 & e 450 & 2 & 2.4 & 621 & 3 & 5.1 \\
\hline 14 & e260 & 3 & 2.1 & e440 & 2 & 2.4 & 648 & 3 & 5.3 \\
\hline 15 & e250 & 3 & 2.0 & e430 & 2 & 2.3 & 770 & 4 & 8.5 \\
\hline 16 & $\mathrm{e} 250$ & 3 & 2.0 & e420 & 2 & 2.3 & 968 & 6 & 15 \\
\hline 17 & e260 & 3 & 2.1 & e410 & 2 & 2.2 & 876 & 5 & 13 \\
\hline 18 & e330 & 3 & 2.7 & e410 & 2 & 2.2 & 774 & 4 & 9.4 \\
\hline 19 & 1080 & 32 & 168 & e410 & 2 & 2.2 & 733 & 4 & 7.9 \\
\hline 20 & 3880 & 91 & 941 & e410 & 2 & 2.2 & 827 & 5 & 12 \\
\hline 21 & 4090 & 37 & 416 & 722 & 3 & 6.4 & 1030 & 8 & 21 \\
\hline 22 & 2850 & 17 & 132 & 1500 & 17 & 77 & 981 & 7 & 19 \\
\hline 23 & 1820 & 8 & 40 & 1970 & 20 & 104 & 824 & 7 & 15 \\
\hline 24 & 1520 & 8 & 35 & 1980 & 11 & 57 & 711 & 6 & 12 \\
\hline 25 & 2470 & 20 & 135 & 1880 & 8 & 41 & 658 & 6 & 11 \\
\hline 26 & 2400 & 12 & 78 & 1610 & 6 & 27 & 784 & 9 & 19 \\
\hline 27 & 2210 & 10 & 64 & 1350 & 4 & 16 & 930 & 13 & 33 \\
\hline 28 & 3770 & 40 & 410 & 1280 & 4 & 14 & 830 & 13 & 29 \\
\hline 29 & 3540 & 25 & 247 & 1260 & 4 & 13 & 714 & 11 & 21 \\
\hline 30 & 2540 & 10 & 71 & --- & --- & --- & 664 & 9 & 16 \\
\hline 31 & 1820 & 5 & 26 & --- & --- & --- & 641 & 7 & 13 \\
\hline ГОТАL & 38572 & --- & 2800.5 & 26012 & --- & 425.1 & 24202 & --- & 370.4 \\
\hline
\end{tabular}


Appendix 3. Daily mean streamflow, daily mean suspended-sediment concentration, and daily total suspended-sediment discharge at three continuous-record sediment stations in the Housatonic River Basin, western Massachusetts, March 1994 through April 1996-Continued

01198000 GREEN RIVER NEAR GREAT BARRINGTON, MA

SUSPENDED-SEDIMENT DISCHARGE (TONS/DAY), WATER YEAR OCTOBER 1993 TO SEPTEMBER 1994

\begin{tabular}{|c|c|c|c|c|c|c|c|c|c|}
\hline AY & $\begin{array}{c}\text { MEAN } \\
\text { DISCHARGE } \\
\text { (CFS) }\end{array}$ & $\begin{array}{l}\text { MEAN } \\
\text { CONCEN- } \\
\text { TRATION } \\
\text { (MG/L) }\end{array}$ & $\begin{array}{l}\text { SEDIMENT } \\
\text { DISCHARGE } \\
\text { (TONS/DAY) }\end{array}$ & $\begin{array}{c}\text { MEAN } \\
\text { DISCHARGE } \\
\text { (CFS) }\end{array}$ & $\begin{array}{l}\text { MEAN } \\
\text { CONCEN- } \\
\text { TRATION } \\
\text { (MG/L) }\end{array}$ & $\begin{array}{l}\text { SEDIMENT } \\
\text { DISCHARGE } \\
\text { (TONS/DAY) }\end{array}$ & $\begin{array}{c}\text { MEAN } \\
\text { DISCHARGE } \\
\text { (CFS) }\end{array}$ & $\begin{array}{l}\text { MEAN } \\
\text { CONCEN- } \\
\text { TRATION } \\
\text { (MG/L) }\end{array}$ & $\begin{array}{l}\text { SEDIMENT } \\
\text { DISCHARGE } \\
\text { (TONS/DAY) }\end{array}$ \\
\hline
\end{tabular}

JANUARY

FEBRUARY

MARCH

\begin{tabular}{|c|c|c|c|c|c|c|c|c|c|}
\hline 1 & --- & --- & --- & --- & --- & --- & --- & --- & --- \\
\hline 2 & --- & --- & --- & --- & --- & --- & --- & --- & --- \\
\hline 3 & --- & --- & --- & --- & --- & --- & --- & --- & --- \\
\hline 4 & --- & --- & --- & --- & --- & --- & --- & --- & --- \\
\hline 5 & --- & --- & --- & --- & --- & --- & --- & --- & --- \\
\hline 6 & --- & --- & --- & --- & --- & --- & --- & --- & --- \\
\hline 7 & --- & --- & --- & --- & --- & --- & --- & --- & --- \\
\hline 8 & --- & --- & --- & --- & --- & --- & --- & --- & --- \\
\hline 9 & --- & --- & --- & --- & --- & --- & --- & --- & --- \\
\hline 10 & --- & --- & --- & --- & --- & --- & --- & --- & --- \\
\hline 11 & --- & --- & --- & --- & --- & --- & --- & --- & --- \\
\hline 12 & --- & --- & --- & --- & --- & --- & --- & --- & --- \\
\hline 13 & --- & --- & --- & --- & --- & --- & --- & --- & --- \\
\hline 14 & --- & --- & --- & --- & --- & --- & --- & --- & --- \\
\hline 15 & --- & --- & --- & --- & --- & --- & --- & --- & --- \\
\hline 16 & --- & --- & --- & --- & --- & --- & --- & --- & --- \\
\hline 17 & --- & --- & --- & --- & --- & --- & --- & --- & --- \\
\hline 18 & --- & --- & --- & --- & --- & --- & --- & --- & --- \\
\hline 19 & --- & --- & --- & --- & --- & --- & --- & --- & --- \\
\hline 20 & --- & --- & --- & --- & --- & --- & --- & --- & --- \\
\hline 21 & --- & --- & --- & --- & --- & --- & --- & --- & --- \\
\hline 22 & --- & --- & --- & --- & --- & --- & --- & --- & --- \\
\hline 23 & --- & --- & --- & --- & --- & --- & --- & --- & --- \\
\hline 24 & --- & --- & --- & --- & --- & --- & e370 & 26 & 28 \\
\hline 25 & --- & --- & --- & --- & --- & --- & e470 & 36 & 45 \\
\hline 26 & --- & --- & --- & --- & --- & --- & e430 & 26 & 31 \\
\hline 27 & --- & --- & --- & --- & --- & --- & e 440 & 24 & 29 \\
\hline 28 & --- & --- & --- & --- & --- & --- & e560 & 46 & 70 \\
\hline 29 & --- & --- & --- & --- & --- & --- & e550 & 24 & 37 \\
\hline 30 & --- & --- & --- & --- & --- & --- & e 420 & 11 & 13 \\
\hline 31 & --- & --- & --- & --- & --- & --- & e360 & 13 & 13 \\
\hline OTAL & --- & --- & --- & --- & --- & --- & --- & --- & --- \\
\hline
\end{tabular}


Appendix 3. Daily mean streamflow, daily mean suspended-sediment concentration, and daily total suspended-sediment discharge at three continuous-record sediment stations in the Housatonic River Basin, western Massachusetts, March 1994 through April 1996-Continued

01198000 GREEN RIVER NEAR GREAT BARRINGTON, MA-Continued SUSPENDED-SEDIMENT DISCHARGE (TONS/DAY), WATER YEAR OCTOBER 1993 TO SEPTEMBER 1994

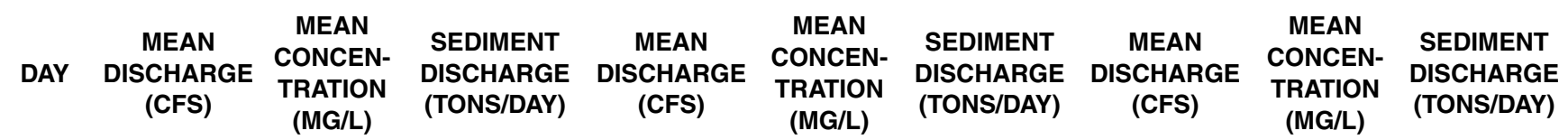
APRIL

\section{MAY}

\begin{tabular}{|c|c|c|}
\hline e370 & 15 & 15 \\
\hline e370 & 11 & 11 \\
\hline e390 & 11 & 12 \\
\hline e610 & 30 & 49 \\
\hline e550 & 16 & 24 \\
\hline e600 & 25 & 45 \\
\hline e990 & 211 & 631 \\
\hline e540 & 20 & 31 \\
\hline e430 & 11 & 13 \\
\hline e500 & 10 & 14 \\
\hline e670 & 27 & 52 \\
\hline e430 & 8 & 8.9 \\
\hline e550 & 29 & 66 \\
\hline e760 & 41 & 103 \\
\hline e460 & 12 & 15 \\
\hline e600 & 19 & 31 \\
\hline e560 & 40 & 60 \\
\hline e440 & 8 & 9.5 \\
\hline e350 & 8 & 7.6 \\
\hline e300 & 7 & 5.7 \\
\hline e240 & 6 & 3.9 \\
\hline e190 & 5 & 2.6 \\
\hline e160 & 5 & 2.2 \\
\hline e135 & 5 & 1.8 \\
\hline e120 & 4 & 1.3 \\
\hline e110 & 4 & 1.2 \\
\hline e100 & 3 & .81 \\
\hline e120 & 3 & .97 \\
\hline e110 & 2 & .59 \\
\hline e96 & 2 & .52 \\
\hline --- & --- & --- \\
\hline
\end{tabular}

$1219.59 \quad 3004$

130

4

e92

e86

e82

3

3
2
2

2

2
6

6
3

2

2

2
4

4
2

2
2

2
2

13
6

6
2
2$$
2
$$$$
\begin{aligned}
& 2 \\
& 2
\end{aligned}
$$$$
2
$$$$
\begin{aligned}
& 2 \\
& 1
\end{aligned}
$$$$
\begin{aligned}
& 1 \\
& 1
\end{aligned}
$$$$
\begin{aligned}
& 1 \\
& 1
\end{aligned}
$$$$
2
$$$$
5
$$$$
\begin{aligned}
& 5 \\
& 4
\end{aligned}
$$$$
\begin{aligned}
& 4 \\
& 3
\end{aligned}
$$$$
2
$$

--- 1219.59

5

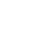

$\begin{array}{cc}1.8 & 49 \\ 1.2 & 46 \\ .75 & 44 \\ .46 & 40 \\ .44 & 37\end{array}$

JUNE$$
.44
$$$$
.43
$$$$
2.3
$$$$
.79
$$$$
.51
$$$$
.45
$$$$
1.0
$$$$
.63
$$$$
.43
$$$$
.41
$$$$
7.5
$$$$
2.6
$$$$
.76
$$$$
.71
$$$$
.59
$$$$
.47
$$$$
.37
$$$$
.30
$$$$
.24
$$$$
.42
$$$$
1.3
$$$$
.84
$$$$
\begin{aligned}
& .84 \\
& .70
\end{aligned}
$$$$
.51
$$$$
.36
$$$$
.25
$$$$
\text { --- } 29.96
$$

35$$
\begin{aligned}
& 35 \\
& 43
\end{aligned}
$$$$
38
$$$$
34
$$$$
30
$$$$
27
$$$$
\begin{aligned}
& 27 \\
& 38
\end{aligned}
$$$$
38
$$$$
34
$$$$
31
$$$$
\begin{aligned}
& 27 \\
& 26
\end{aligned}
$$$$
\begin{aligned}
& 26 \\
& 24
\end{aligned}
$$$$
\begin{aligned}
& 24 \\
& 22
\end{aligned}
$$$$
\begin{aligned}
& 22 \\
& 22
\end{aligned}
$$$$
21
$$$$
\begin{aligned}
& 21 \\
& 20
\end{aligned}
$$$$
\begin{aligned}
& 20 \\
& 18
\end{aligned}
$$$$
\begin{aligned}
& 18 \\
& 18
\end{aligned}
$$$$
\begin{aligned}
& 18 \\
& 19
\end{aligned}
$$

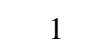

$\begin{array}{lr}1 & 0.18 \\ 1 & .13 \\ 1 & .12 \\ 1 & .11 \\ 1 & .10 \\ 1 & .10\end{array}$

$\begin{array}{ll}1 & .10\end{array}$

$3 \quad .31$$$
1 \quad .11
$$$$
\begin{array}{ll}
1 & .09
\end{array}
$$$$
\begin{array}{ll}
1 & .09 \\
1 & .08
\end{array}
$$$$
\begin{array}{ll}
1 & .07
\end{array}
$$$$
\begin{array}{ll}
1 & .07 \\
2 & .51
\end{array}
$$$$
\begin{array}{ll}
5 & .51 \\
2 & .26 \\
2 & .18
\end{array}
$$$$
2 \quad .17
$$$$
2 \quad .16
$$$$
\begin{array}{ll}
2 & .16 \\
2 & .16
\end{array}
$$$$
\begin{array}{ll}
2 & .16 \\
2 & .15
\end{array}
$$$$
\begin{array}{ll}
2 & .15 \\
3 & .15
\end{array}
$$$$
\begin{array}{ll}
3 & .15 \\
3 & .16
\end{array}
$$$$
\begin{aligned}
& 3 \\
& 3
\end{aligned}
$$$$
\begin{array}{ll}
3 & .16 \\
3 & .16
\end{array}
$$$$
\begin{array}{ll}
3 & .16 \\
3 & .14
\end{array}
$$$$
\begin{array}{ll}
3 & .13 \\
3 & .13
\end{array}
$$$$
\begin{array}{ll}
2 & .12
\end{array}
$$$$
\begin{array}{ll}
2 & .12 \\
2 & .11
\end{array}
$$$$
\begin{array}{ll}
2 & .11 \\
2 & .10
\end{array}
$$$$
\begin{array}{ll}
2 & .10 \\
3 & .27 \\
3 & .23
\end{array}
$$

TOTAL 1185

\begin{abstract}
3004
\end{abstract}


Appendix 3. Daily mean streamflow, daily mean suspended-sediment concentration, and daily total suspended-sediment discharge at three continuous-record sediment stations in the Housatonic River Basin, western Massachusetts, March 1994 through April 1996-Continued

01198000 GREEN RIVER NEAR GREAT BARRINGTON, MA-Continued SUSPENDED-SEDIMENT DISCHARGE (TONS/DAY), WATER YEAR OCTOBER 1993 TO SEPTEMBER 1994

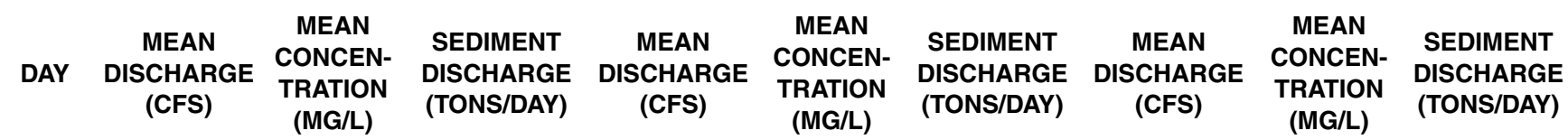
JULY

AUGUST

\begin{tabular}{|c|c|c|c|c|c|c|c|c|c|}
\hline 1 & 22 & 3 & 0.18 & e32 & 3 & 0.26 & 29 & 5 & 0.39 \\
\hline 2 & 19 & 3 & .15 & 29 & 3 & .25 & 27 & 5 & .37 \\
\hline 3 & 16 & 3 & .13 & 26 & 3 & .22 & 25 & 5 & .36 \\
\hline 4 & 15 & 3 & .12 & 24 & 3 & .19 & 23 & 5 & .35 \\
\hline 5 & 14 & 3 & .11 & e24 & 2 & .13 & 22 & 6 & .34 \\
\hline 6 & 13 & 3 & .11 & $\mathrm{e} 22$ & 2 & .12 & 20 & 6 & .32 \\
\hline 7 & 13 & 3 & .11 & e21 & 2 & .11 & 19 & 6 & .30 \\
\hline 8 & 17 & 4 & .23 & e19 & 1 & .05 & 18 & 5 & .25 \\
\hline 9 & 19 & 4 & .22 & e18 & 1 & .05 & 18 & 4 & .20 \\
\hline 10 & 14 & 3 & .12 & 16 & 1 & .04 & 16 & 4 & .16 \\
\hline 11 & 13 & 3 & .10 & e16 & $\mathrm{a} 0$ & .01 & 15 & 3 & .13 \\
\hline 12 & 12 & 3 & .09 & 15 & $\mathrm{a} 0$ & .02 & 14 & 4 & .15 \\
\hline 13 & 11 & 3 & .09 & 15 & 1 & .02 & 14 & 5 & .18 \\
\hline 14 & 11 & 3 & .09 & $\mathrm{e} 20$ & 1 & .05 & 15 & 6 & .26 \\
\hline 15 & 10 & 3 & .08 & $\mathrm{e} 20$ & 2 & .11 & 15 & 8 & .30 \\
\hline 16 & 9.9 & 3 & .07 & e17 & 2 & .09 & 14 & 7 & .27 \\
\hline 17 & 10 & 2 & .07 & e16 & 2 & .09 & 14 & 6 & .24 \\
\hline 18 & 12 & 2 & .07 & e55 & 9 & 1.5 & 16 & 6 & .24 \\
\hline 19 & 11 & 2 & .06 & 42 & 5 & .54 & 14 & 5 & .19 \\
\hline 20 & 13 & 3 & .14 & 33 & 4 & .32 & 13 & 4 & .16 \\
\hline 21 & 17 & 3 & .14 & 36 & 4 & .50 & 12 & 4 & .13 \\
\hline 22 & 14 & 2 & .08 & e100 & 8 & 2.4 & 12 & 4 & .11 \\
\hline 23 & 77 & 6 & 1.5 & e73 & 3 & .59 & 19 & 3 & .16 \\
\hline 24 & 39 & 3 & .29 & e54 & 2 & .29 & 18 & 3 & .14 \\
\hline 25 & 27 & 2 & .17 & 46 & 2 & .28 & 16 & 2 & .11 \\
\hline 26 & 32 & 4 & .54 & 42 & 3 & .29 & 15 & 2 & .09 \\
\hline 27 & 44 & 5 & .60 & 38 & 3 & .29 & 35 & 7 & 1.2 \\
\hline 28 & e57 & 8 & 1.3 & 35 & 3 & .30 & 165 & 19 & 11 \\
\hline 29 & e52 & 5 & .70 & 37 & 4 & .35 & 74 & 3 & .67 \\
\hline 30 & e43 & 3 & .35 & 33 & 4 & .35 & 57 & 2 & .31 \\
\hline 31 & e37 & 3 & .30 & 31 & 4 & .37 & --- & --- & --- \\
\hline COTAL & 713.9 & --- & 8.31 & 1005 & --- & 10.18 & 784 & --- & 19.08 \\
\hline
\end{tabular}


Appendix 3. Daily mean streamflow, daily mean suspended-sediment concentration, and daily total suspended-sediment discharge at three continuous-record sediment stations in the Housatonic River Basin, western Massachusetts, March 1994 through April 1996-Continued

01198000 GREEN RIVER NEAR GREAT BARRINGTON, MA-Continued SUSPENDED-SEDIMENT DISCHARGE (TONS/DAY), WATER YEAR OCTOBER 1994 TO SEPTEMBER 1995

\begin{tabular}{|c|c|c|c|c|c|c|c|c|c|}
\hline AY & $\begin{array}{c}\text { MEAN } \\
\text { DISCHARGE } \\
\text { (CFS) }\end{array}$ & $\begin{array}{c}\text { MEAN } \\
\text { CONCEN- } \\
\text { TRATION } \\
\text { (MG/L) }\end{array}$ & $\begin{array}{l}\text { SEDIMENT } \\
\text { DISCHARGE } \\
\text { (TONS/DAY) }\end{array}$ & $\begin{array}{c}\text { MEAN } \\
\text { DISCHARGE } \\
\text { (CFS) }\end{array}$ & $\begin{array}{l}\text { MEAN } \\
\text { CONCEN- } \\
\text { TRATION } \\
\text { (MG/L) }\end{array}$ & $\begin{array}{l}\text { SEDIMENT } \\
\text { DISCHARGE } \\
\text { (TONS/DAY) }\end{array}$ & $\begin{array}{l}\text { MEAN } \\
\text { DISCHARGE } \\
\text { (CFS) }\end{array}$ & $\begin{array}{c}\text { MEAN } \\
\text { CONCEN- } \\
\text { TRATION } \\
\text { (MG/L) }\end{array}$ & $\begin{array}{l}\text { SEDIMENT } \\
\text { DISCHARGE } \\
\text { (TONS/DAY) }\end{array}$ \\
\hline
\end{tabular}

OCTOBER

\begin{tabular}{|c|c|c|}
\hline 1 & 46 & 2 \\
\hline 2 & 47 & 1 \\
\hline 3 & 42 & 1 \\
\hline 4 & 37 & 1 \\
\hline 5 & 35 & 1 \\
\hline 6 & 32 & 1 \\
\hline 7 & 31 & 1 \\
\hline 8 & 29 & 1 \\
\hline 9 & 28 & 1 \\
\hline 10 & 38 & 1 \\
\hline 11 & 35 & 1 \\
\hline 12 & 32 & 1 \\
\hline 13 & 30 & 1 \\
\hline 14 & 28 & 1 \\
\hline 15 & 27 & 1 \\
\hline 16 & 26 & 1 \\
\hline 17 & 25 & 1 \\
\hline 18 & 25 & 2 \\
\hline 19 & 24 & 2 \\
\hline 20 & 25 & 3 \\
\hline 21 & 29 & 5 \\
\hline 22 & 27 & 5 \\
\hline 23 & 27 & 4 \\
\hline 24 & 31 & 4 \\
\hline 25 & 29 & 3 \\
\hline 26 & 27 & 3 \\
\hline 27 & 26 & 2 \\
\hline 28 & 25 & 2 \\
\hline 29 & 24 & 2 \\
\hline 30 & 23 & 1 \\
\hline 31 & 23 & 1 \\
\hline
\end{tabular}

NOVEMBER

0.23
.19
.14

$.14-30$

.1028

$.09 \quad 27$

$.09 \quad 26$

$.08 \quad 28$

$.08 \quad 27$

$.08 \quad 26$

1026

$.09 \quad 26$

$.09 \quad 25$

$.08 \quad 24$

$.08 \quad 24$

$.08 \quad 23$

$.08 \quad 22$

$.10 \quad 22$

$.11 \quad 22$

.10

.17

.41

.37

.32

.30

.24

.20

.16

.13

.11

.09

.07

4.56

1027

$\begin{array}{lr}1 & 0.08 \\ 2 & .14 \\ 1 & .12 \\ 1 & .08 \\ 1 & .06\end{array}$

.06

.04

$$
.03
$$$$
.02
$$$$
.02
$$$$
.03
$$$$
.03
$$$$
.04
$$$$
.05
$$$$
.05
$$$$
.06
$$$$
.04
$$$$
.03
$$$$
.02
$$$$
.03
$$$$
.04
$$$$
.08
$$$$
.25
$$$$
.13
$$$$
.09
$$$$
.08
$$$$
.08
$$$$
\begin{array}{r}
.08 \\
.08
\end{array}
$$$$
5.3
$$$$
5.2
$$$$
.50
$$$$
\text { --- }
$$

$\begin{array}{ll}-- & 12.80\end{array}$

\begin{tabular}{|c|c|c|}
\hline 84 & 2 & 0.37 \\
\hline 76 & 1 & .30 \\
\hline 71 & 1 & .25 \\
\hline 68 & 1 & .21 \\
\hline 144 & 34 & 23 \\
\hline 228 & 16 & 12 \\
\hline 163 & 2 & .92 \\
\hline 148 & 2 & .64 \\
\hline 124 & 1 & .44 \\
\hline 117 & 1 & .36 \\
\hline 190 & 7 & 3.6 \\
\hline 156 & 2 & .69 \\
\hline 121 & 1 & .33 \\
\hline 113 & 1 & .31 \\
\hline 107 & 1 & .29 \\
\hline 97 & 1 & .26 \\
\hline 93 & 1 & .25 \\
\hline 96 & 1 & .27 \\
\hline 91 & 1 & .31 \\
\hline 82 & 2 & .34 \\
\hline 76 & 2 & .39 \\
\hline 72 & 2 & .39 \\
\hline 70 & 2 & .38 \\
\hline 207 & 22 & 17 \\
\hline 257 & 10 & 7.8 \\
\hline 177 & 6 & 2.9 \\
\hline 151 & 6 & 2.4 \\
\hline 138 & 6 & 2.2 \\
\hline 125 & 5 & 1.7 \\
\hline 93 & 4 & 1.1 \\
\hline 92 & 3 & .86 \\
\hline 3827 & --- & 82.26 \\
\hline
\end{tabular}


Appendix 3. Daily mean streamflow, daily mean suspended-sediment concentration, and daily total suspended-sediment discharge at three continuous-record sediment stations in the Housatonic River Basin, western Massachusetts, March 1994 through April 1996-Continued

01198000 GREEN RIVER NEAR GREAT BARRINGTON, MA-Continued SUSPENDED-SEDIMENT DISCHARGE (TONS/DAY), WATER YEAR OCTOBER 1994 TO SEPTEMBER 1995

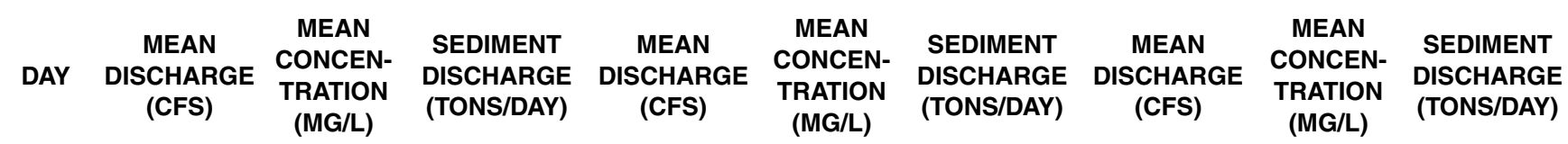
JANUARY

FEBRUARY

\begin{tabular}{|c|c|c|c|c|c|c|c|c|}
\hline 146 & 6 & 2.4 & 103 & 1 & 0.32 & 97 & 3 & 0.81 \\
\hline 156 & 4 & 1.7 & 97 & 1 & .36 & 80 & 2 & .43 \\
\hline 128 & 3 & .99 & 83 & 2 & .37 & 73 & 2 & .39 \\
\hline 115 & 3 & .81 & 80 & 2 & .43 & 69 & 2 & .37 \\
\hline 97 & 2 & .61 & e76 & 3 & .62 & 67 & 2 & .36 \\
\hline 90 & 2 & .52 & e74 & 4 & .80 & 77 & 2 & .42 \\
\hline 140 & 5 & 2.2 & e72 & 4 & .78 & 92 & 5 & 1.5 \\
\hline 131 & 2 & .83 & e70 & 5 & .94 & 455 & 220 & 452 \\
\hline 110 & 1 & .34 & e67 & 5 & .92 & 912 & 136 & 438 \\
\hline 98 & 1 & .26 & 63 & 4 & .66 & 389 & 28 & 30 \\
\hline 88 & 1 & .24 & 62 & 3 & .46 & 293 & 17 & 14 \\
\hline 88 & 1 & .24 & e58 & 3 & .47 & 250 & 13 & 8.5 \\
\hline 120 & 3 & 1.0 & e55 & 2 & .30 & 260 & 9 & 6.5 \\
\hline 178 & 7 & 3.6 & e52 & 1 & .14 & 281 & 8 & 6.1 \\
\hline 228 & 9 & 5.5 & e50 & 1 & .14 & 279 & 7 & 5.3 \\
\hline 233 & 9 & 5.7 & 51 & 1 & .14 & 257 & 6 & 4.3 \\
\hline 250 & 7 & 5.1 & 49 & 1 & .15 & 229 & 6 & 3.6 \\
\hline 200 & 4 & 2.2 & 46 & 1 & .16 & 202 & 6 & 3.1 \\
\hline 179 & 3 & 1.4 & 46 & 1 & .18 & 178 & 5 & 2.6 \\
\hline 228 & 8 & 6.6 & 47 & 2 & .22 & 160 & 5 & 2.2 \\
\hline 354 & 13 & 12 & 48 & 2 & .25 & 164 & 5 & 2.2 \\
\hline 323 & 5 & 4.2 & 45 & 2 & .25 & 173 & 4 & 2.0 \\
\hline 266 & 3 & 2.2 & 44 & 2 & .24 & 149 & 4 & 1.5 \\
\hline 228 & 3 & 1.8 & 67 & 3 & .56 & 135 & 3 & 1.2 \\
\hline 198 & 3 & 1.6 & e62 & 2 & .33 & 121 & 3 & .91 \\
\hline 174 & 3 & 1.4 & e54 & 1 & .15 & 110 & 2 & .71 \\
\hline 157 & 2 & 1.0 & e48 & 1 & .13 & 102 & 2 & .57 \\
\hline 129 & 2 & .68 & 81 & 8 & 2.0 & 96 & 2 & .45 \\
\hline 116 & 2 & .50 & --- & --- & --- & 91 & 1 & .35 \\
\hline 110 & 1 & .38 & --- & --- & --- & 87 & 1 & .28 \\
\hline 108 & 1 & .31 & --- & --- & --- & 90 & 1 & .25 \\
\hline 5166 & --- & 68.31 & 1750 & --- & 12.47 & 6018 & --- & 990.90 \\
\hline
\end{tabular}


Appendix 3. Daily mean streamflow, daily mean suspended-sediment concentration, and daily total suspended-sediment discharge at three continuous-record sediment stations in the Housatonic River Basin, western Massachusetts, March 1994 through April 1996-Continued

01198000 GREEN RIVER NEAR GREAT BARRINGTON, MA-Continued SUSPENDED-SEDIMENT DISCHARGE (TONS/DAY), WATER YEAR OCTOBER 1994 TO SEPTEMBER 1995

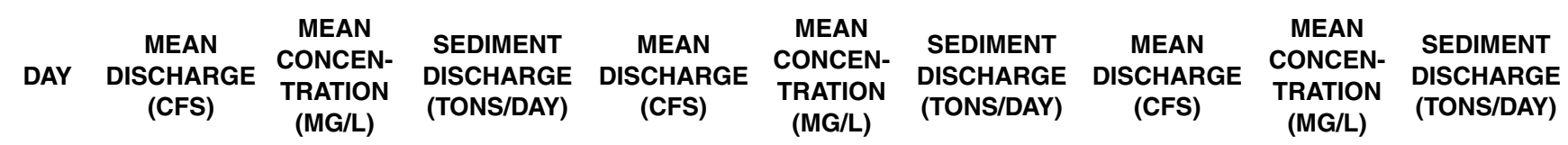
APRIL

MAY

\begin{tabular}{|c|c|c|c|c|c|c|c|c|c|}
\hline 1 & 83 & 1 & 0.28 & 73 & 3 & 0.63 & 34 & 2 & 0.19 \\
\hline 2 & 77 & 2 & .32 & 69 & 3 & .64 & 31 & 2 & .17 \\
\hline 3 & 72 & 2 & .37 & 65 & 4 & .65 & 31 & 2 & .17 \\
\hline 4 & 74 & 2 & .34 & 60 & 4 & .62 & 47 & 2 & .31 \\
\hline 5 & 72 & 1 & .28 & 59 & 3 & .51 & 39 & 1 & .12 \\
\hline 6 & 64 & 1 & .21 & 64 & 3 & .44 & 34 & 1 & .10 \\
\hline 7 & 63 & 1 & .18 & 55 & 2 & .30 & 32 & 1 & .10 \\
\hline 8 & 62 & 1 & .17 & 51 & 2 & .22 & 29 & 1 & .10 \\
\hline 9 & 63 & 1 & .17 & 47 & 1 & .16 & 27 & 1 & .10 \\
\hline 10 & 73 & 1 & .20 & 46 & 1 & .14 & 25 & 2 & .10 \\
\hline 11 & 64 & 1 & .17 & 50 & 2 & .25 & 24 & 2 & .11 \\
\hline 12 & 60 & 1 & .16 & 51 & 2 & .28 & 27 & 2 & .13 \\
\hline 13 & 147 & 20 & 8.8 & 46 & 2 & .25 & 28 & 2 & .15 \\
\hline 14 & 118 & 15 & 4.8 & 43 & 2 & .23 & 24 & 2 & .13 \\
\hline 15 & 102 & 12 & 3.3 & 45 & 2 & .24 & 22 & 2 & .12 \\
\hline 16 & 92 & 6 & 1.6 & 43 & 2 & .23 & 20 & 2 & .11 \\
\hline 17 & 86 & 2 & .57 & 40 & 2 & .21 & 19 & 2 & .10 \\
\hline 18 & 81 & 2 & .44 & 40 & 2 & .21 & 17 & 2 & .09 \\
\hline 19 & 116 & 10 & 3.6 & 40 & 2 & .22 & 16 & 2 & .09 \\
\hline 20 & 109 & 4 & 1.3 & 39 & 2 & .21 & 15 & 2 & .08 \\
\hline 21 & 100 & 3 & .78 & 36 & 2 & .19 & 14 & 2 & .07 \\
\hline 22 & 108 & 2 & .60 & 34 & 2 & .18 & 13 & 2 & .06 \\
\hline 23 & 95 & 2 & .51 & 32 & 2 & .17 & 13 & 1 & .05 \\
\hline 24 & 89 & 2 & .48 & 30 & 2 & .16 & 12 & 1 & .04 \\
\hline 25 & 83 & 2 & .45 & 40 & 2 & .22 & 12 & 1 & .04 \\
\hline 26 & 79 & 2 & .43 & 36 & 2 & .19 & 12 & 1 & .03 \\
\hline 27 & 75 & 2 & .41 & 33 & 2 & .18 & 12 & 1 & .03 \\
\hline 28 & 85 & 3 & .70 & 31 & 2 & .16 & 11 & 1 & .03 \\
\hline 29 & 81 & 3 & .66 & 32 & 2 & .18 & 10 & 1 & .03 \\
\hline 30 & 74 & 3 & .60 & 56 & 3 & .43 & 9.8 & 1 & .03 \\
\hline 31 & --- & --- & --- & 41 & 2 & .22 & --- & --- & --- \\
\hline OTAL & 2547 & --- & 32.88 & 1427 & --- & 8.92 & 659.8 & --- & 2.98 \\
\hline
\end{tabular}


Appendix 3. Daily mean streamflow, daily mean suspended-sediment concentration, and daily total suspended-sediment discharge at three continuous-record sediment stations in the Housatonic River Basin, western Massachusetts, March 1994 through April 1996-Continued

01198000 GREEN RIVER NEAR GREAT BARRINGTON, MA-Continued SUSPENDED-SEDIMENT DISCHARGE (TONS/DAY), WATER YEAR OCTOBER 1994 TO SEPTEMBER 1995

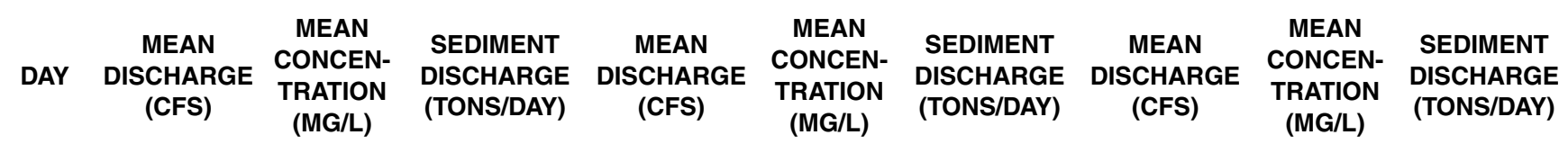
JULY

AUGUST

SEPTEMBER

\begin{tabular}{|c|c|c|c|c|c|c|c|c|c|}
\hline 1 & 9.8 & 1 & 0.03 & 4.4 & 1 & 0.01 & 3.0 & 1 & 0.01 \\
\hline 2 & 20 & 6 & .31 & 4.3 & 1 & .01 & 2.9 & 1 & .01 \\
\hline 3 & 14 & 5 & .19 & 4.7 & 1 & .01 & 2.8 & 1 & .01 \\
\hline 4 & 12 & 4 & .13 & 4.7 & 1 & .01 & 2.7 & 1 & .01 \\
\hline 5 & 11 & 3 & .09 & 5.4 & 1 & .02 & 2.7 & 1 & .01 \\
\hline 6 & 9.9 & 3 & .07 & 8.1 & 1 & .02 & 2.7 & 1 & .01 \\
\hline 7 & 9.6 & 2 & .05 & 7.2 & 1 & .02 & 2.6 & 1 & .01 \\
\hline 8 & 9.5 & 2 & .05 & 6.7 & 1 & .02 & 2.8 & 1 & .01 \\
\hline 9 & 8.9 & 2 & .05 & 6.2 & 2 & .03 & 3.1 & 1 & .01 \\
\hline 10 & 8.5 & 2 & .05 & 5.8 & 2 & .04 & 3.2 & 1 & .01 \\
\hline 11 & 8.4 & 2 & .05 & 5.4 & 3 & .04 & 3.1 & 1 & .01 \\
\hline 12 & 8.0 & 2 & .04 & 5.3 & 2 & .03 & 3.0 & 1 & .01 \\
\hline 13 & 7.5 & 2 & .04 & 5.3 & 1 & .02 & 3.3 & 1 & .01 \\
\hline 14 & 6.9 & 2 & .04 & 4.9 & 1 & .02 & 3.2 & 1 & .01 \\
\hline 15 & 6.7 & 2 & .03 & 4.8 & 2 & .02 & 3.1 & 1 & .01 \\
\hline 16 & 6.4 & 2 & .03 & 4.6 & 3 & .03 & 3.0 & 1 & .01 \\
\hline 17 & 6.3 & 2 & .03 & 4.3 & 4 & .04 & 4.1 & 1 & .01 \\
\hline 18 & 6.6 & 1 & .02 & 4.0 & 3 & .03 & 4.1 & 1 & .01 \\
\hline 19 & 6.0 & 1 & .02 & 3.8 & 2 & .02 & 3.5 & 1 & .01 \\
\hline 20 & 5.6 & 1 & .02 & 3.6 & 1 & .01 & 3.3 & 1 & .01 \\
\hline 21 & 5.5 & 1 & .02 & 3.4 & 1 & .01 & 3.3 & 1 & .01 \\
\hline 22 & 5.4 & 1 & .02 & 3.3 & 1 & .01 & 4.2 & 1 & .02 \\
\hline 23 & 5.2 & 1 & .01 & 3.2 & 1 & .01 & 5.7 & 2 & .03 \\
\hline 24 & 5.5 & 1 & .02 & 3.1 & 1 & .01 & 4.3 & 1 & .02 \\
\hline 25 & 6.0 & 1 & .02 & 3.1 & 1 & .01 & 3.8 & 1 & .01 \\
\hline 26 & 5.8 & 1 & .02 & 3.1 & 1 & .01 & 4.1 & 1 & .01 \\
\hline 27 & 6.0 & 1 & .02 & 3.1 & 1 & .01 & 4.2 & 2 & .02 \\
\hline 28 & 5.6 & 1 & .02 & 3.0 & 1 & .01 & 3.8 & 2 & .02 \\
\hline 29 & 5.5 & 1 & .02 & 2.9 & 1 & .01 & 3.6 & 2 & .02 \\
\hline 30 & 5.0 & 1 & .01 & 2.9 & 1 & .01 & 3.6 & 2 & .02 \\
\hline 31 & 4.7 & 1 & .01 & 2.9 & 1 & .01 & --- & --- & --- \\
\hline TOTAL & 241.8 & --- & 1.53 & 137.5 & --- & 0.56 & 102.8 & --- & 0.38 \\
\hline YEAR & 23836.9 & & 1218.55 & & & & & & \\
\hline
\end{tabular}


Appendix 3. Daily mean streamflow, daily mean suspended-sediment concentration, and daily total suspended-sediment discharge at three continuous-record sediment stations in the Housatonic River Basin, western Massachusetts, March 1994 through April 1996-Continued

01198000 GREEN RIVER NEAR GREAT BARRINGTON, MA—Continued SEDIMENT DISCHARGE, SUSPENDED (TONS/DAY), WATER YEAR OCTOBER 1995 TO SEPTEMBER 1996

\begin{tabular}{|c|c|c|c|c|c|c|c|c|c|}
\hline AY & $\begin{array}{c}\text { MEAN } \\
\text { DISCHARGE } \\
\text { (CFS) }\end{array}$ & $\begin{array}{c}\text { MEAN } \\
\text { CONCEN- } \\
\text { TRATION } \\
\text { (MG/L) }\end{array}$ & $\begin{array}{l}\text { SEDIMENT } \\
\text { DISCHARGE } \\
\text { (TONS/DAY) }\end{array}$ & $\begin{array}{c}\text { MEAN } \\
\text { DISCHARGE } \\
\text { (CFS) }\end{array}$ & $\begin{array}{l}\text { MEAN } \\
\text { CONCEN- } \\
\text { TRATION } \\
\text { (MG/L) }\end{array}$ & $\begin{array}{l}\text { SEDIMENT } \\
\text { DISCHARGE } \\
\text { (TONS/DAY) }\end{array}$ & $\begin{array}{c}\text { MEAN } \\
\text { DISCHARGE } \\
\text { (CFS) }\end{array}$ & $\begin{array}{l}\text { MEAN } \\
\text { CONCEN- } \\
\text { TRATION } \\
\text { (MG/L) }\end{array}$ & $\begin{array}{l}\text { SEDIMENT } \\
\text { DISCHARGE } \\
\text { (TONS/DAY) }\end{array}$ \\
\hline
\end{tabular}

OCTOBER

\begin{tabular}{|c|c|}
\hline 1 & 3.4 \\
\hline 2 & 3.5 \\
\hline 3 & 3.4 \\
\hline 4 & 4.1 \\
\hline 5 & 7.3 \\
\hline 6 & 51 \\
\hline 7 & 37 \\
\hline 8 & 22 \\
\hline 9 & 17 \\
\hline 10 & 15 \\
\hline 11 & 13 \\
\hline 12 & 12 \\
\hline 13 & 11 \\
\hline 14 & 11 \\
\hline 15 & 29 \\
\hline 16 & 29 \\
\hline 17 & 23 \\
\hline 18 & 20 \\
\hline 19 & 19 \\
\hline 20 & 17 \\
\hline 21 & 109 \\
\hline 22 & 491 \\
\hline 23 & 168 \\
\hline 24 & 116 \\
\hline 25 & 103 \\
\hline 26 & 86 \\
\hline 27 & 74 \\
\hline 28 & 318 \\
\hline 29 & 259 \\
\hline 30 & 173 \\
\hline 31 & 139 \\
\hline TAL & 2383.7 \\
\hline
\end{tabular}

NOVEMBER

0.01
.01
.01
.01
.07

$.31 \quad 92$

$.12 \quad 135$

.09

.08

.07

.06

.06

.07

.58

.23

.12

.11

.10

$$
.10
$$

62

115

2.1

1.1

.91

$$
.70
$$$$
.60
$$$$
35
$$

7.0

1.4

.75

230.77

118
143
151
127
108
96
92
135
108

93

91

895

455

$$
346
$$$$
475
$$$$
342
$$$$
264
$$$$
222
$$$$
207
$$$$
186
$$

166

$$
149
$$$$
131
$$$$
116
$$$$
104
$$$$
98
$$$$
92
$$$$
87
$$

\begin{tabular}{|c|c|}
\hline 2 & 0.64 \\
\hline 5 & 2.2 \\
\hline 4 & 1.8 \\
\hline 4 & 1.4 \\
\hline 4 & 1.2 \\
\hline 4 & 1.0 \\
\hline 4 & 1.1 \\
\hline 6 & 2.1 \\
\hline 3 & .87 \\
\hline 3 & .76 \\
\hline 3 & .73 \\
\hline 131 & 406 \\
\hline 22 & 28 \\
\hline 13 & 12 \\
\hline 18 & 23 \\
\hline 8 & 7.8 \\
\hline 4 & 2.8 \\
\hline 2 & 1.4 \\
\hline 1 & .83 \\
\hline 1 & .54 \\
\hline 1 & .53 \\
\hline 1 & .58 \\
\hline 2 & .63 \\
\hline 2 & .68 \\
\hline 3 & .74 \\
\hline 3 & .85 \\
\hline 4 & .93 \\
\hline 3 & .64 \\
\hline 2 & .38 \\
\hline 1 & .23 \\
\hline --- & --- \\
\hline
\end{tabular}$$
83
$$$$
77
$$$$
\text { --- }
$$

5757

DECEMBER

0.21

.22

.21

.24

.25

.26

.26

.25

.25

.26

.27

.27

.37

.53

.87

1.2

1.2

1.1

.97

.90

.82

.75

.70

.63

.57

.53

.48

.44

.40

.40

.41

16.22 
Appendix 3. Daily mean streamflow, daily mean suspended-sediment concentration, and daily total suspended-sediment discharge at three continuous-record sediment stations in the Housatonic River Basin, western Massachusetts, March 1994 through April 1996-Continued

01198000 GREEN RIVER NEAR GREAT BARRINGTON, MA—Continued SEDIMENT DISCHARGE, SUSPENDED (TONS/DAY), WATER YEAR OCTOBER 1995 TO SEPTEMBER 1996

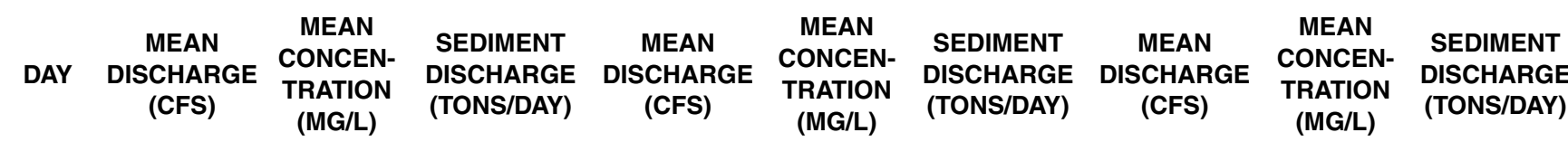

JANUARY

\begin{tabular}{|c|c|}
\hline 1 & 36 \\
\hline 2 & 36 \\
\hline 3 & 35 \\
\hline 4 & 34 \\
\hline 5 & e34 \\
\hline 6 & e34 \\
\hline 7 & e34 \\
\hline 8 & e35 \\
\hline 9 & e35 \\
\hline 10 & e35 \\
\hline 11 & 35 \\
\hline 12 & 35 \\
\hline 13 & 36 \\
\hline 14 & 36 \\
\hline 15 & 35 \\
\hline 16 & 33 \\
\hline 17 & 37 \\
\hline 18 & 43 \\
\hline 19 & 856 \\
\hline 20 & 2700 \\
\hline 21 & 723 \\
\hline 22 & 483 \\
\hline 23 & 343 \\
\hline 24 & 520 \\
\hline 25 & 972 \\
\hline 26 & 459 \\
\hline 27 & 1180 \\
\hline 28 & 1200 \\
\hline 29 & 538 \\
\hline 30 & 397 \\
\hline 31 & 299 \\
\hline
\end{tabular}

FEBRUARY

219
191
162
$\mathrm{e} 140$
$\mathrm{e} 128$

5.0

4260.82 e117

e108

99

97

91

90

84

e64

62

60

55

54

51

e45

50

170

462

379

374

322

257

217

245

210

-.-

\begin{tabular}{|c|c|}
\hline 3 & 2.1 \\
\hline 3 & 1.4 \\
\hline 2 & .97 \\
\hline 2 & .76 \\
\hline 2 & .69 \\
\hline 2 & .63 \\
\hline 2 & .58 \\
\hline 2 & .53 \\
\hline 2 & .52 \\
\hline 2 & .49 \\
\hline 2 & .49 \\
\hline 2 & .45 \\
\hline 2 & .35 \\
\hline 2 & .33 \\
\hline 2 & .32 \\
\hline 2 & .30 \\
\hline 2 & .29 \\
\hline 2 & .27 \\
\hline 2 & .24 \\
\hline 2 & .32 \\
\hline 41 & 25 \\
\hline 115 & 154 \\
\hline 32 & 34 \\
\hline 27 & 27 \\
\hline 26 & 23 \\
\hline 17 & 12 \\
\hline 17 & 9.8 \\
\hline 18 & 12 \\
\hline 15 & 8.7 \\
\hline --- & --- \\
\hline --- & --- \\
\hline
\end{tabular}

4603

--- $\quad 317.53$

$$
\begin{array}{r}
162 \\
147 \\
135 \\
114 \\
108 \\
113 \\
104 \\
94 \\
88 \\
\mathrm{e} 83 \\
\mathrm{e} \\
89 \\
85 \\
85 \\
96 \\
138 \\
161 \\
129 \\
124 \\
128 \\
154 \\
156 \\
145 \\
126 \\
113 \\
111 \\
132 \\
122 \\
109 \\
104 \\
98 \\
91
\end{array}
$$

$\begin{array}{lll}--- & 317.53 & 3634\end{array}$

MARCH 
Appendix 3. Daily mean streamflow, daily mean suspended-sediment concentration, and daily total suspended-sediment discharge at three continuous-record sediment stations in the Housatonic River Basin, western Massachusetts, March 1994 through April 1996-Continued

01198125 HOUSATONIC RIVER NEAR ASHLEY FALLS, MA

SUSPENDED-SEDIMENT DISCHARGE (TONS/DAY), WATER YEAR OCTOBER 1993 TO SEPTEMBER 1994

\begin{tabular}{|c|c|c|c|c|c|c|c|c|c|}
\hline AY & $\begin{array}{c}\text { MEAN } \\
\text { DISCHARGE } \\
\text { (CFS) }\end{array}$ & $\begin{array}{l}\text { MEAN } \\
\text { CONCEN- } \\
\text { TRATION } \\
\text { (MG/L) }\end{array}$ & $\begin{array}{l}\text { SEDIMENT } \\
\text { DISCHARGE } \\
\text { (TONS/DAY) }\end{array}$ & $\begin{array}{c}\text { MEAN } \\
\text { DISCHARGE } \\
\text { (CFS) }\end{array}$ & $\begin{array}{l}\text { MEAN } \\
\text { CONCEN- } \\
\text { TRATION } \\
\text { (MG/L) }\end{array}$ & $\begin{array}{l}\text { SEDIMENT } \\
\text { DISCHARGE } \\
\text { (TONS/DAY) }\end{array}$ & $\begin{array}{c}\text { MEAN } \\
\text { DISCHARGE } \\
\text { (CFS) }\end{array}$ & $\begin{array}{l}\text { MEAN } \\
\text { CONCEN- } \\
\text { TRATION } \\
\text { (MG/L) }\end{array}$ & $\begin{array}{l}\text { SEDIMENT } \\
\text { DISCHARGE } \\
\text { (TONS/DAY) }\end{array}$ \\
\hline
\end{tabular}

JANUARY

FEBRUARY

MARCH

\begin{tabular}{|c|c|c|c|c|c|c|c|c|c|}
\hline 1 & --- & --- & --- & --- & --- & --- & --- & --- & --- \\
\hline 2 & --- & --- & --- & --- & --- & --- & --- & --- & --- \\
\hline 3 & --- & --- & --- & --- & --- & --- & --- & --- & --- \\
\hline 4 & --- & --- & --- & --- & --- & --- & --- & --- & -- \\
\hline 5 & --- & --- & --- & --- & --- & --- & --- & --- & --- \\
\hline 6 & --- & --- & --- & --- & --- & --- & --- & --- & --- \\
\hline 7 & --- & --- & --- & --- & --- & --- & --- & --- & --- \\
\hline 8 & --- & --- & --- & --- & --- & --- & --- & --- & --- \\
\hline 9 & --- & --- & --- & --- & --- & --- & --- & --- & --- \\
\hline 10 & --- & --- & --- & --- & --- & --- & --- & --- & --- \\
\hline 11 & --- & --- & --- & --- & --- & --- & --- & --- & --- \\
\hline 12 & --- & --- & --- & --- & --- & --- & --- & --- & --- \\
\hline 13 & --- & --- & --- & --- & --- & --- & --- & --- & --- \\
\hline 14 & --- & --- & --- & --- & --- & --- & --- & --- & --- \\
\hline 15 & --- & --- & --- & --- & --- & --- & --- & --- & --- \\
\hline 16 & --- & --- & --- & --- & --- & --- & --- & --- & --- \\
\hline 17 & --- & --- & --- & --- & --- & --- & --- & --- & --- \\
\hline 18 & --- & --- & --- & --- & --- & --- & --- & --- & --- \\
\hline 19 & --- & --- & --- & --- & --- & --- & --- & --- & --- \\
\hline 20 & --- & --- & --- & --- & --- & --- & --- & --- & --- \\
\hline 21 & --- & --- & --- & --- & --- & --- & --- & --- & --- \\
\hline 22 & --- & --- & --- & --- & --- & --- & --- & --- & --- \\
\hline 23 & --- & --- & --- & --- & --- & --- & --- & --- & --- \\
\hline 24 & --- & --- & --- & --- & --- & --- & --- & --- & --- \\
\hline 25 & --- & --- & --- & --- & --- & --- & e2840 & 90 & 692 \\
\hline 26 & --- & --- & --- & --- & --- & --- & e2860 & 83 & 644 \\
\hline 27 & --- & --- & --- & --- & --- & --- & e2780 & 62 & 470 \\
\hline 28 & --- & --- & --- & --- & --- & --- & e3040 & 64 & 527 \\
\hline 29 & --- & --- & --- & --- & --- & --- & e3360 & 73 & 656 \\
\hline 30 & --- & --- & --- & --- & --- & --- & e3320 & 68 & 614 \\
\hline 31 & --- & --- & --- & --- & --- & --- & e3020 & 57 & 467 \\
\hline OTAL & --- & --- & --- & --- & --- & --- & --- & --- & -- \\
\hline
\end{tabular}


Appendix 3. Daily mean streamflow, daily mean suspended-sediment concentration, and daily total suspended-sediment discharge at three continuous-record sediment stations in the Housatonic River Basin, western Massachusetts, March 1994 through April 1996-Continued

01198125 HOUSATONIC RIVER NEAR ASHLEY FALLS, MA-Continued SUSPENDED-SEDIMENT DISCHARGE (TONS/DAY), WATER YEAR OCTOBER 1993 TO SEPTEMBER 1994

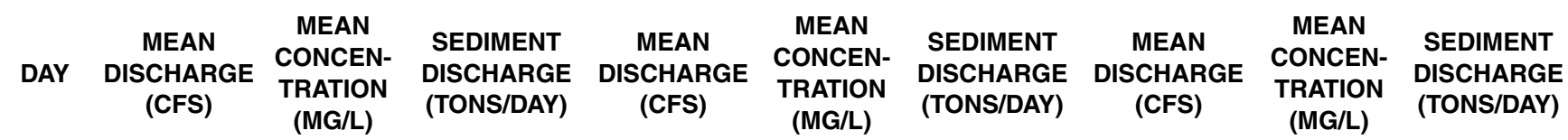
APRIL

MAY

\begin{tabular}{|c|c|c|c|c|}
\hline 1 & e3000 & 54 & 435 & e1200 \\
\hline 2 & e3140 & 57 & 479 & $\mathrm{e} 1450$ \\
\hline 3 & e3320 & 60 & 543 & e1350 \\
\hline 4 & e3800 & 76 & 785 & e1160 \\
\hline 5 & e3970 & 73 & 785 & e1040 \\
\hline 6 & e3970 & 54 & 580 & e945 \\
\hline 7 & e4220 & 59 & 681 & 916 \\
\hline 8 & e4800 & 75 & 962 & 1110 \\
\hline 9 & e4530 & 52 & 668 & 1470 \\
\hline 10 & e4000 & 38 & 410 & 1400 \\
\hline 11 & e4200 & 37 & 420 & 1180 \\
\hline 12 & e4000 & 48 & 518 & 1060 \\
\hline 13 & e4000 & 39 & 421 & 1150 \\
\hline 14 & e4680 & 52 & 662 & 1100 \\
\hline 15 & e5280 & 60 & 856 & 952 \\
\hline 16 & e5000 & 50 & 675 & 1000 \\
\hline 17 & e5000 & 52 & 702 & 1690 \\
\hline 18 & e4500 & 40 & 486 & 1960 \\
\hline 19 & e 3750 & 31 & 314 & 1750 \\
\hline 20 & e3100 & 24 & 201 & 1470 \\
\hline 21 & e2600 & 21 & 147 & 1280 \\
\hline 22 & e2000 & 19 & 103 & 1120 \\
\hline 23 & e1700 & 18 & 83 & 990 \\
\hline 24 & e1500 & 17 & 69 & 904 \\
\hline 25 & e1380 & 16 & 60 & 820 \\
\hline 26 & e1270 & 14 & 48 & 802 \\
\hline 27 & e1220 & 13 & 43 & 813 \\
\hline 28 & e1260 & 12 & 41 & 756 \\
\hline 29 & e1210 & 11 & 36 & 700 \\
\hline 30 & e1110 & 10 & 30 & 623 \\
\hline 31 & --- & --- & --- & 559 \\
\hline TAL & 97510 & --- & 12243 & 34720 \\
\hline
\end{tabular}

11

14
23
18
12
10
10

$47 \quad 521$

$90 \quad 503$

$\begin{array}{ll}65 & 469\end{array}$

$39 \quad 437$

$28 \quad 407$

$$
26
$$$$
22
$$$$
47
$$$$
69
$$$$
49
$$

10

$$
\begin{aligned}
& 34 \\
& 29
\end{aligned}
$$$$
11 \quad 33
$$$$
10 \quad 29
$$$$
822
$$

$9 \quad 27$

$27 \quad 123$

$\begin{array}{ll}27 & 123 \\ 24 & 126\end{array}$

$\begin{array}{ll}24 & 126 \\ 23 & 107\end{array}$

15
15

$\begin{array}{ll}15 & 61 \\ 11 & 39\end{array}$

$\begin{array}{ll}11 & 39 \\ 10 & 31\end{array}$

924

$8 \quad 20$

$\begin{array}{ll}7 & 17\end{array}$

7
6

$\begin{array}{ll}7 & 15 \\ 6 & 14\end{array}$

$\begin{array}{ll}6 & 14 \\ 6 & 12\end{array}$

$\begin{array}{ll}6 & 12\end{array}$

$\begin{array}{ll}6 & 12 \\ 6 & 11\end{array}$

7

9.9
1277.9

$---\quad 1277.9$

521
503
469
437
407

JUNE

$$
441
$$$$
494
$$$$
427
$$$$
376
$$$$
328
$$$$
335
$$$$
416
$$$$
427
$$$$
431
$$$$
409
$$$$
361
$$$$
327
$$$$
335
$$$$
302
$$$$
257
$$$$
258
$$$$
252
$$$$
234
$$$$
234
$$$$
243
$$$$
\begin{aligned}
& 243 \\
& 236
\end{aligned}
$$$$
240
$$$$
240
$$$$
477
$$$$
\begin{array}{ll}
7 & 9.5
\end{array}
$$$$
\begin{array}{ll}
7 & 9.4
\end{array}
$$$$
6 \quad 8.0
$$$$
\begin{array}{ll}
6 & 6.6
\end{array}
$$$$
\begin{array}{ll}
6 & 5.6
\end{array}
$$$$
\begin{array}{ll}
4 & 4.5 \\
5 & 6.1
\end{array}
$$$$
\begin{array}{ll}
6 & 7.4
\end{array}
$$$$
\begin{array}{ll}
6 & 7.4 \\
3 & 3.7
\end{array}
$$$$
\begin{array}{ll}
3 & 3.7
\end{array}
$$$$
2 \quad 2.2
$$$$
\begin{array}{ll}
2 & 1.8 \\
2 & 2.0
\end{array}
$$$$
\begin{array}{ll}
2 & 2.0 \\
4 & 4.9
\end{array}
$$$$
\begin{array}{ll}
4 & 4.9 \\
4 & 5.2
\end{array}
$$$$
4 \quad 4.7
$$$$
4 \quad 4.4
$$$$
\begin{array}{ll}
4 & 4.4 \\
4 & 3.9
\end{array}
$$$$
4 \quad 3.5
$$$$
\begin{array}{ll}
4 & 3.5 \\
4 & 3.6
\end{array}
$$$$
\begin{array}{ll}
4 & 3.6 \\
4 & 3.3
\end{array}
$$$$
2.8
$$$$
2.8
$$$$
2.9
$$$$
\begin{aligned}
& 2.8 \\
& 3.0
\end{aligned}
$$$$
3.3
$$$$
3.4
$$$$
3.7
$$$$
3.9
$$$$
13
$$$$
\text { --- --- --- }
$$

10795

141.7 
Appendix 3. Daily mean streamflow, daily mean suspended-sediment concentration, and daily total suspended-sediment discharge at three continuous-record sediment stations in the Housatonic River Basin, western Massachusetts, March 1994 through April 1996-Continued

01198125 HOUSATONIC RIVER NEAR ASHLEY FALLS, MA-Continued SUSPENDED-SEDIMENT DISCHARGE (TONS/DAY), WATER YEAR OCTOBER 1993 TO SEPTEMBER 1994

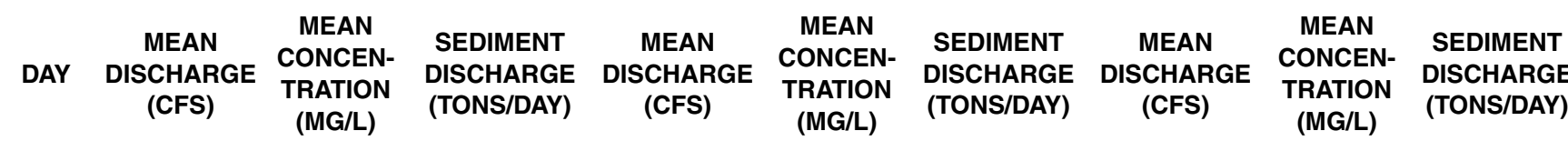

JULY

\begin{tabular}{|c|c|c|c|c|c|c|c|c|c|}
\hline 1 & 511 & 8 & 10 & 429 & 8 & 8.9 & 314 & 12 & 10 \\
\hline 2 & 410 & 6 & 6.6 & 359 & 7 & 6.9 & 284 & 11 & 8.6 \\
\hline 3 & 320 & 6 & 5.2 & 326 & 7 & 5.8 & 256 & 10 & 6.9 \\
\hline 4 & 257 & 6 & 4.2 & 304 & 6 & 5.0 & 233 & 9 & 5.7 \\
\hline 5 & 219 & 6 & 3.5 & 275 & 5 & 3.9 & 215 & 8 & 4.7 \\
\hline 6 & 194 & 6 & 3.1 & 261 & 5 & 3.2 & 200 & 7 & 4.0 \\
\hline 7 & 187 & 6 & 3.0 & 253 & 4 & 2.6 & 189 & 7 & 3.4 \\
\hline 8 & 185 & 6 & 3.0 & 232 & 3 & 2.1 & 182 & 6 & 3.0 \\
\hline 9 & 225 & 7 & 4.0 & 206 & 3 & 1.6 & 178 & 6 & 3.0 \\
\hline 10 & 228 & 6 & 3.5 & 181 & 2 & 1.2 & 177 & 7 & 3.1 \\
\hline 11 & 199 & 5 & 2.5 & 173 & 2 & .98 & 173 & 7 & 3.2 \\
\hline 12 & 179 & 4 & 1.9 & 163 & 2 & .88 & 166 & 7 & 3.2 \\
\hline 13 & 166 & 3 & 1.4 & 157 & 2 & .85 & 162 & 7 & 3.2 \\
\hline 14 & 164 & 3 & 1.1 & 194 & 4 & 2.6 & 169 & 8 & 3.5 \\
\hline 15 & 153 & 2 & .85 & 277 & 19 & 14 & 179 & 8 & 3.8 \\
\hline 16 & 151 & 2 & .74 & 284 & 20 & 15 & 169 & 8 & 3.6 \\
\hline 17 & 147 & 2 & .64 & 230 & 17 & 11 & 163 & 8 & 3.5 \\
\hline 18 & 146 & 1 & .57 & 328 & 20 & 18 & 179 & 8 & 3.9 \\
\hline 19 & 160 & 1 & .56 & 607 & 28 & 46 & 186 & 8 & 4.0 \\
\hline 20 & 164 & 1 & .51 & 612 & 25 & 41 & 171 & 8 & 3.7 \\
\hline 21 & 199 & 1 & .57 & 484 & 20 & 26 & 156 & 8 & 3.4 \\
\hline 22 & 266 & 2 & 1.4 & 751 & 41 & 91 & 151 & 8 & 3.2 \\
\hline 23 & 760 & 15 & 34 & 1270 & 44 & 152 & 176 & 6 & 3.0 \\
\hline 24 & 969 & 16 & 43 & 1020 & 30 & 82 & 257 & 5 & 3.5 \\
\hline 25 & 749 & 13 & 26 & 734 & 24 & 48 & 277 & 4 & 3.1 \\
\hline 26 & 542 & 10 & 15 & 558 & 20 & 30 & 243 & 4 & 2.6 \\
\hline 27 & 644 & 13 & 22 & 471 & 16 & 20 & 243 & 5 & 3.5 \\
\hline 28 & 638 & 12 & 21 & 417 & 13 & 15 & 731 & 35 & 82 \\
\hline 29 & 722 & 12 & 23 & 439 & 14 & 17 & 1110 & 47 & 140 \\
\hline 30 & 590 & 10 & 15 & 453 & 15 & 19 & 903 & 24 & 59 \\
\hline 31 & 506 & 9 & 12 & 374 & 14 & 14 & --- & --- & --- \\
\hline OTAL & 10950 & --- & 269.84 & 12822 & --- & 705.51 & 8192 & --- & 391.3 \\
\hline
\end{tabular}


Appendix 3. Daily mean streamflow, daily mean suspended-sediment concentration, and daily total suspended-sediment discharge at three continuous-record sediment stations in the Housatonic River Basin, western Massachusetts, March 1994 through April 1996-Continued

01198125 HOUSATONIC RIVER NEAR ASHLEY FALLS, MA—Continued SEDIMENT DISCHARGE, SUSPENDED (TONS/DAY), WATER YEAR OCTOBER 1994 TO SEPTEMBER 1995

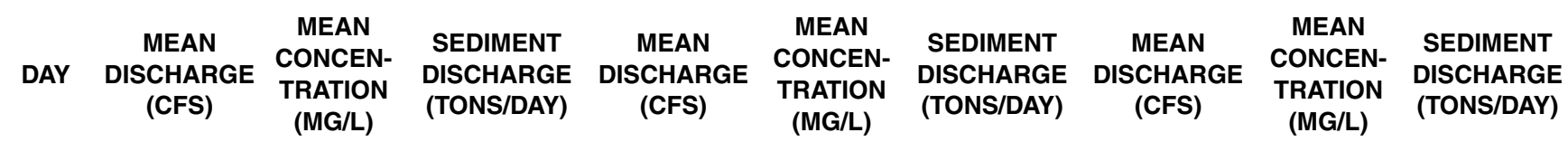

OCTOBER

\begin{tabular}{|c|c|c|c|c|}
\hline 1 & 646 & 14 & 24 & 313 \\
\hline 2 & 516 & 10 & 13 & 348 \\
\hline 3 & 471 & 7 & 9.3 & 391 \\
\hline 4 & 449 & 6 & 7.6 & 385 \\
\hline 5 & 416 & 7 & 7.4 & 345 \\
\hline 6 & 408 & 7 & 8.0 & 316 \\
\hline 7 & 403 & 7 & 7.5 & 341 \\
\hline 8 & 386 & 5 & 5.0 & 330 \\
\hline 9 & 372 & 4 & 3.6 & 311 \\
\hline 10 & 398 & 3 & 2.9 & 312 \\
\hline 11 & 422 & 2 & 2.4 & 302 \\
\hline 12 & 390 & 2 & 2.5 & 308 \\
\hline 13 & 361 & 3 & 2.7 & 308 \\
\hline 14 & 337 & 3 & 3.0 & 307 \\
\hline 15 & 314 & 4 & 3.2 & 292 \\
\hline 16 & 292 & 3 & 2.3 & 287 \\
\hline 17 & 272 & 2 & 1.5 & 287 \\
\hline 18 & 260 & 1 & 1.0 & 287 \\
\hline 19 & 285 & 1 & .81 & 269 \\
\hline 20 & 305 & 1 & .82 & 271 \\
\hline 21 & 342 & 1 & .92 & 266 \\
\hline 22 & 380 & 1 & 1.0 & 381 \\
\hline 23 & 368 & 1 & .99 & 525 \\
\hline 24 & 377 & 1 & 1.1 & 491 \\
\hline 25 & 385 & 2 & 1.7 & 413 \\
\hline 26 & 379 & 2 & 2.5 & 405 \\
\hline 27 & 371 & 4 & 3.6 & 406 \\
\hline 28 & 352 & 3 & 2.6 & 461 \\
\hline 29 & 335 & 2 & 1.5 & 981 \\
\hline 30 & 323 & 1 & .96 & 1090 \\
\hline 31 & 311 & 1 & .84 & --- \\
\hline OTAL & 11626 & --- & 126.24 & 11729 \\
\hline
\end{tabular}

NOVEMBER

\begin{tabular}{|c|c|c|c|c|}
\hline 1 & 0.85 & 904 & 14 & 35 \\
\hline 1 & .94 & 755 & 12 & 25 \\
\hline 1 & 1.1 & 663 & 12 & 21 \\
\hline 1 & 1.4 & 623 & 11 & 19 \\
\hline 2 & 1.7 & 710 & 20 & 43 \\
\hline 3 & 2.2 & 1470 & 53 & 208 \\
\hline 4 & 3.3 & 1710 & 44 & 204 \\
\hline 5 & 4.2 & 1470 & 25 & 100 \\
\hline 4 & 3.7 & 1190 & 30 & 97 \\
\hline 4 & 3.3 & 1040 & 25 & 71 \\
\hline 3 & 2.8 & 1200 & 29 & 96 \\
\hline 3 & 2.5 & 1350 & 34 & 125 \\
\hline 3 & 2.2 & 1060 & 19 & 55 \\
\hline 2 & 2.0 & 942 & 11 & 27 \\
\hline 2 & 1.7 & 860 & 10 & 23 \\
\hline 2 & 1.6 & 805 & 10 & 22 \\
\hline 2 & 1.5 & 793 & 10 & 21 \\
\hline 2 & 1.6 & 826 & 9 & 21 \\
\hline 2 & 1.5 & 849 & 9 & 20 \\
\hline 2 & 1.5 & 777 & 7 & 15 \\
\hline 2 & 1.5 & 714 & 5 & 10 \\
\hline 5 & 5.5 & 682 & 4 & 7.7 \\
\hline 7 & 9.8 & 659 & 4 & 7.1 \\
\hline 4 & 5.2 & 1040 & 24 & 88 \\
\hline 3 & 3.1 & 2140 & 62 & 352 \\
\hline 2 & 2.7 & 2320 & 45 & 284 \\
\hline 2 & 2.4 & 1810 & 23 & 115 \\
\hline 12 & 18 & 1380 & 11 & 42 \\
\hline 40 & 104 & 1190 & 12 & 38 \\
\hline 21 & 63 & 925 & 14 & 34 \\
\hline --- & --- & 930 & 14 & 35 \\
\hline --- & 256.79 & 33787 & --- & 2260.8 \\
\hline
\end{tabular}

\section{DECEMBER}


Appendix 3. Daily mean streamflow, daily mean suspended-sediment concentration, and daily total suspended-sediment discharge at three continuous-record sediment stations in the Housatonic River Basin, western Massachusetts, March 1994 through April 1996-Continued

01198125 HOUSATONIC RIVER NEAR ASHLEY FALLS, MA—Continued SEDIMENT DISCHARGE, SUSPENDED (TONS/DAY), WATER YEAR OCTOBER 1994 TO SEPTEMBER 1995

\begin{tabular}{|c|c|c|c|c|c|c|c|c|c|}
\hline DAY & $\begin{array}{c}\text { MEAN } \\
\text { DISCHARGE } \\
\text { (CFS) }\end{array}$ & $\begin{array}{l}\text { MEAN } \\
\text { CONCEN- } \\
\text { TRATION } \\
\text { (MG/L) }\end{array}$ & $\begin{array}{l}\text { SEDIMENT } \\
\text { DISCHARGE } \\
\text { (TONS/DAY) }\end{array}$ & $\begin{array}{l}\text { MEAN } \\
\text { DISCHARGE } \\
\text { (CFS) }\end{array}$ & $\begin{array}{l}\text { MEAN } \\
\text { CONCEN- } \\
\text { TRATION } \\
\text { (MG/L) }\end{array}$ & $\begin{array}{l}\text { SEDIMENT } \\
\text { DISCHARGE } \\
\text { (TONS/DAY) }\end{array}$ & $\begin{array}{c}\text { MEAN } \\
\text { DISCHARGE } \\
\text { (CFS) }\end{array}$ & $\begin{array}{l}\text { MEAN } \\
\text { CONCEN- } \\
\text { TRATION } \\
\text { (MG/L) }\end{array}$ & $\begin{array}{c}\text { SEDIMENT } \\
\text { DISCHARGE } \\
\text { (TONS/DAY) }\end{array}$ \\
\hline & & JANUARY & & & FEBRUARY & & & MARCH & \\
\hline 1 & 1080 & 16 & 47 & 983 & 8 & 22 & 1010 & 37 & 101 \\
\hline 2 & 1440 & 22 & 85 & 917 & 9 & 21 & 974 & 27 & 73 \\
\hline 3 & 1440 & 16 & 61 & 833 & 9 & 20 & 838 & 17 & 38 \\
\hline 4 & 1220 & 11 & 37 & 792 & 9 & 19 & 746 & 12 & 23 \\
\hline 5 & e1000 & 8 & 22 & e740 & 8 & 14 & 681 & 8 & 15 \\
\hline 6 & e900 & 6 & 15 & e710 & 8 & 13 & 690 & 7 & 13 \\
\hline 7 & 1140 & 13 & 40 & e680 & 8 & 14 & 820 & 15 & 34 \\
\hline 8 & 1450 & 25 & 98 & e660 & 8 & 14 & 1160 & 34 & 114 \\
\hline 9 & 1300 & 18 & 62 & e640 & 7 & 12 & 3130 & 94 & 792 \\
\hline 10 & 1140 & 15 & 45 & e630 & 7 & 12 & 3970 & 82 & 881 \\
\hline 11 & e980 & 15 & 40 & e620 & 7 & 12 & 3540 & 54 & 518 \\
\hline 12 & e920 & 15 & 37 & e590 & 7 & 11 & 2560 & 37 & 258 \\
\hline 13 & 989 & 15 & 39 & e580 & 7 & 11 & 2010 & 28 & 150 \\
\hline 14 & 1190 & 20 & 63 & e580 & 7 & 11 & 1990 & 25 & 132 \\
\hline 15 & 1550 & 30 & 128 & 598 & 7 & 11 & 2040 & 33 & 180 \\
\hline 16 & 2000 & 45 & 244 & 636 & 7 & 12 & 2080 & 34 & 192 \\
\hline 17 & 2240 & 54 & 330 & 644 & 7 & 12 & 2130 & 32 & 184 \\
\hline 18 & 2180 & 50 & 296 & 617 & 7 & 11 & 2060 & 31 & 171 \\
\hline 19 & 1940 & 38 & 201 & 595 & 6 & 10 & 1890 & 23 & 117 \\
\hline 20 & 1730 & 30 & 141 & 573 & 6 & 9.7 & 1670 & 18 & 81 \\
\hline 21 & 2170 & 35 & 204 & 568 & 6 & 9.4 & 1510 & 18 & 74 \\
\hline 22 & 2650 & 41 & 291 & 560 & 6 & 9.1 & 1590 & 21 & 88 \\
\hline 23 & 2680 & 29 & 209 & 539 & 6 & 8.7 & 1590 & 18 & 79 \\
\hline 24 & 2280 & 24 & 147 & 619 & 10 & 18 & 1440 & 16 & 63 \\
\hline 25 & 1890 & 22 & 111 & 820 & 18 & 40 & 1270 & 14 & 49 \\
\hline 26 & 1620 & 19 & 82 & 713 & 9 & 18 & 1120 & 13 & 39 \\
\hline 27 & 1430 & 16 & 62 & 612 & 6 & 9.9 & 1010 & 11 & 31 \\
\hline 28 & 1190 & 14 & 44 & 668 & 16 & 32 & 928 & 10 & 26 \\
\hline 29 & e1100 & 12 & 36 & --- & --- & --- & 865 & 10 & 23 \\
\hline 30 & e 1050 & 10 & 27 & --- & --- & --- & 814 & 10 & 22 \\
\hline 31 & e1000 & 8 & 21 & --- & --- & --- & 819 & 10 & 22 \\
\hline ГОТАL & 46889 & --- & 3265 & 18717 & --- & 416.8 & 48945 & --- & 4583 \\
\hline
\end{tabular}


Appendix 3. Daily mean streamflow, daily mean suspended-sediment concentration, and daily total suspended-sediment discharge at three continuous-record sediment stations in the Housatonic River Basin, western Massachusetts, March 1994 through April 1996-Continued

01198125 HOUSATONIC RIVER NEAR ASHLEY FALLS, MA—Continued SEDIMENT DISCHARGE, SUSPENDED (TONS/DAY), WATER YEAR OCTOBER 1994 TO SEPTEMBER 1995

\begin{tabular}{|c|c|c|c|c|c|c|c|c|c|}
\hline DAY & $\begin{array}{c}\text { MEAN } \\
\text { DISCHARGE } \\
\text { (CFS) }\end{array}$ & $\begin{array}{l}\text { MEAN } \\
\text { CONCEN- } \\
\text { TRATION } \\
\text { (MG/L) }\end{array}$ & $\begin{array}{l}\text { SEDIMENT } \\
\text { DISCHARGE } \\
\text { (TONS/DAY) }\end{array}$ & $\begin{array}{c}\text { MEAN } \\
\text { DISCHARGE } \\
\text { (CFS) }\end{array}$ & $\begin{array}{l}\text { MEAN } \\
\text { CONCEN- } \\
\text { TRATION } \\
\text { (MG/L) }\end{array}$ & $\begin{array}{l}\text { SEDIMENT } \\
\text { DISCHARGE } \\
\text { (TONS/DAY) }\end{array}$ & $\begin{array}{c}\text { MEAN } \\
\text { DISCHARGE } \\
\text { (CFS) }\end{array}$ & $\begin{array}{l}\text { MEAN } \\
\text { CONCEN- } \\
\text { TRATION } \\
\text { (MG/L) }\end{array}$ & $\begin{array}{c}\text { SEDIMENT } \\
\text { DISCHARGE } \\
\text { (TONS/DAY) }\end{array}$ \\
\hline & & APRIL & & & MAY & & & JUNE & \\
\hline 1 & 839 & 9 & 19 & 649 & 4 & 6.4 & 390 & 5 & 5.6 \\
\hline 2 & 780 & 7 & 15 & 632 & 3 & 5.7 & 338 & 6 & 5.3 \\
\hline 3 & 718 & 6 & 12 & 607 & 3 & 5.0 & 321 & 5 & 4.6 \\
\hline 4 & 698 & 6 & 12 & 598 & 3 & 5.3 & 461 & 12 & 17 \\
\hline 5 & 773 & 7 & 15 & 554 & 4 & 5.5 & 653 & 19 & 34 \\
\hline 6 & 732 & 6 & 11 & 574 & 4 & 6.1 & 637 & 17 & 30 \\
\hline 7 & 665 & 5 & 9.0 & 597 & 4 & 5.8 & 486 & 14 & 19 \\
\hline 8 & 646 & 5 & 8.7 & 535 & 3 & 4.7 & 393 & 12 & 13 \\
\hline 9 & 657 & 5 & 8.9 & 500 & 3 & 4.1 & 336 & 11 & 9.6 \\
\hline 10 & 732 & 5 & 10 & 465 & 3 & 3.8 & 297 & 9 & 7.3 \\
\hline 11 & 802 & 7 & 14 & 463 & 3 & 3.8 & 274 & 8 & 5.9 \\
\hline 12 & 677 & 6 & 10 & 536 & 3 & 4.4 & 270 & 7 & 5.2 \\
\hline 13 & 901 & 30 & 75 & 577 & 3 & 4.9 & 302 & 7 & 5.7 \\
\hline 14 & 1270 & 39 & 133 & 522 & 3 & 4.6 & 327 & 7 & 6.0 \\
\hline 15 & 1170 & 34 & 109 & 462 & 3 & 4.2 & 303 & 5 & 3.7 \\
\hline 16 & 952 & 18 & 47 & 489 & 4 & 4.7 & 276 & 5 & 3.9 \\
\hline 17 & 827 & 6 & 14 & 472 & 4 & 4.7 & 251 & 7 & 4.7 \\
\hline 18 & 758 & 4 & 8.2 & 467 & 4 & 4.8 & 236 & 9 & 5.9 \\
\hline 19 & 762 & 5 & 10 & 456 & 4 & 4.9 & 215 & 12 & 7.2 \\
\hline 20 & 1060 & 14 & 41 & 452 & 4 & 4.9 & 203 & 16 & 8.7 \\
\hline 21 & 1080 & 14 & 42 & 435 & 4 & 4.7 & 197 & 15 & 7.9 \\
\hline 22 & 1040 & 11 & 31 & 399 & 4 & 4.3 & 181 & 13 & 6.3 \\
\hline 23 & 980 & 9 & 24 & 378 & 4 & 4.1 & 178 & 11 & 5.3 \\
\hline 24 & 872 & 8 & 18 & 367 & 4 & 3.9 & 172 & 10 & 4.8 \\
\hline 25 & 785 & 6 & 13 & 398 & 4 & 4.1 & 162 & 10 & 4.2 \\
\hline 26 & 728 & 5 & 10 & 429 & 4 & 4.2 & 156 & 9 & 3.7 \\
\hline 27 & 674 & 5 & 8.6 & 398 & 3 & 3.7 & 176 & 8 & 3.7 \\
\hline 28 & 655 & 4 & 7.9 & 375 & 3 & 3.3 & 169 & 7 & 3.0 \\
\hline 29 & 708 & 4 & 8.1 & 355 & 3 & 2.9 & 152 & 6 & 2.4 \\
\hline 30 & 690 & 4 & 7.5 & 444 & 5 & 5.7 & 141 & 5 & 1.9 \\
\hline 31 & --- & --- & --- & 471 & 6 & 7.5 & --- & --- & --- \\
\hline ГОТАL & 24631 & --- & 751.9 & 15056 & --- & 146.7 & 8653 & --- & 245.5 \\
\hline
\end{tabular}


Appendix 3. Daily mean streamflow, daily mean suspended-sediment concentration, and daily total suspended-sediment discharge at three continuous-record sediment stations in the Housatonic River Basin, western Massachusetts, March 1994 through April 1996-Continued

01198125 HOUSATONIC RIVER NEAR ASHLEY FALLS, MA—Continued SEDIMENT DISCHARGE, SUSPENDED (TONS/DAY), WATER YEAR OCTOBER 1994 TO SEPTEMBER 1995

\begin{tabular}{|c|c|c|c|c|c|c|c|c|c|}
\hline$A Y$ & $\begin{array}{c}\text { MEAN } \\
\text { DISCHARGE } \\
\text { (CFS) }\end{array}$ & $\begin{array}{l}\text { MEAN } \\
\text { CONCEN- } \\
\text { TRATION } \\
\text { (MG/L) }\end{array}$ & $\begin{array}{c}\text { SEDIMENT } \\
\text { DISCHARGE } \\
\text { (TONS/DAY) }\end{array}$ & $\begin{array}{c}\text { MEAN } \\
\text { DISCHARGE } \\
\text { (CFS) }\end{array}$ & $\begin{array}{c}\text { MEAN } \\
\text { CONCEN- } \\
\text { TRATION } \\
\text { (MG/L) }\end{array}$ & $\begin{array}{c}\text { SEDIMENT } \\
\text { DISCHARGE } \\
\text { (TONS/DAY) }\end{array}$ & $\begin{array}{c}\text { MEAN } \\
\text { DISCHARGE } \\
\text { (CFS) }\end{array}$ & $\begin{array}{l}\text { MEAN } \\
\text { CONCEN- } \\
\text { TRATION } \\
\text { (MG/L) }\end{array}$ & $\begin{array}{c}\text { SEDIMENT } \\
\text { DISCHARGE } \\
\text { (TONS/DAY) }\end{array}$ \\
\hline
\end{tabular}

JULY

\begin{tabular}{|c|c|}
\hline 1 & 138 \\
\hline 2 & 177 \\
\hline 3 & 238 \\
\hline 4 & 190 \\
\hline 5 & 160 \\
\hline 6 & 139 \\
\hline 7 & 134 \\
\hline 8 & 140 \\
\hline 9 & 143 \\
\hline 10 & 136 \\
\hline 11 & 136 \\
\hline 12 & 150 \\
\hline 13 & 232 \\
\hline 14 & 187 \\
\hline 15 & 154 \\
\hline 16 & 142 \\
\hline 17 & 142 \\
\hline 18 & 147 \\
\hline 19 & 133 \\
\hline 20 & 133 \\
\hline 21 & 126 \\
\hline 22 & 119 \\
\hline 23 & 114 \\
\hline 24 & 119 \\
\hline 25 & 129 \\
\hline 26 & 151 \\
\hline 27 & 170 \\
\hline 28 & 193 \\
\hline 29 & 170 \\
\hline 30 & 166 \\
\hline 31 & 155 \\
\hline OTAL & 4763 \\
\hline
\end{tabular}

YEAR 231842

\section{AUGUST}

$$
1.9
$$$$
2.7
$$$$
3.1
$$$$
2.5
$$$$
2.5
$$$$
2.7
$$$$
3.2
$$$$
3.5
$$$$
3.7
$$$$
3.6
$$$$
3.7
$$$$
4.1
$$$$
6.1
$$$$
2.4
$$$$
1.9
$$$$
2.0
$$$$
2.2
$$$$
2.3
$$$$
2.0
$$$$
1.9
$$$$
1.7
$$$$
1.5
$$$$
1.4
$$$$
1.4
$$$$
1.4
$$$$
1.5
$$$$
1.6
$$$$
1.7
$$$$
1.4
$$$$
1.4
$$$$
1.4
$$$$
74.4
$$$$
12235.53
$$

128
118
113
110

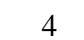

4
4
3
4
7
11
9
9

10

$$
190
$$$$
152
$$$$
141
$$$$
131
$$$$
122
$$$$
113
$$$$
110
$$$$
107
$$$$
104
$$$$
99
$$$$
91
$$$$
86
$$$$
82
$$$$
79
$$$$
76
$$$$
74
$$$$
72
$$$$
70
$$$$
71
$$$$
72
$$$$
73
$$$$
70
$$$$
4119
$$$$
11
$$

(n)

$\begin{array}{ll}1.3 & 72 \\ 1.2 & 76 \\ 1.1 & 81 \\ .98 & 77 \\ 2.5 & 70\end{array}$

SEPTEMBER

$\begin{array}{ll}5.4 & 67\end{array}$

$12 \quad 65$

$\begin{array}{ll}8.4 & 66\end{array}$

5.7

$$
5.1
$$$$
4.3
$$$$
3.4
$$$$
2.7
$$$$
2.1
$$$$
1.6
$$$$
1.3
$$$$
1.1
$$$$
.86
$$$$
.76
$$$$
.66
$$$$
.59
$$$$
.53
$$$$
.48
$$$$
.44
$$$$
.41
$$$$
.49
$$$$
\begin{array}{r}
.49 \\
.60
\end{array}
$$$$
\begin{aligned}
& .60 \\
& .75
\end{aligned}
$$$$
\begin{aligned}
& .75 \\
& .78
\end{aligned}
$$$$
.78
$$$$
.75
$$

69.06$$
125
$$$$
109
$$

$\begin{array}{cc}4 & 0.78 \\ 4 & .89 \\ 5 & 1.0 \\ 5 & 1.1 \\ 5 & 1.0 \\ 6 & 1.1 \\ 6 & 1.1 \\ 7 & 1.2 \\ 5 & .96 \\ 4 & .78\end{array}$

$\begin{array}{ll}3 & .63\end{array}$$$
\begin{array}{ll}
3 & .53
\end{array}
$$$$
\begin{array}{ll}
3 & .46
\end{array}
$$$$
\begin{array}{ll}
2 & .45
\end{array}
$$$$
\begin{array}{ll}
2 & .48
\end{array}
$$$$
\begin{array}{ll}
3 & .54
\end{array}
$$$$
\begin{array}{ll}
3 & .54 \\
3 & -72
\end{array}
$$$$
\begin{array}{ll}
3 & .72 \\
4 & 1.2
\end{array}
$$$$
\begin{array}{ll}
5 & 1.6
\end{array}
$$$$
\begin{array}{ll}
5 & 1.6 \\
6 & 1.7
\end{array}
$$$$
\begin{array}{lll}
97 & 7 & 1.7
\end{array}
$$$$
\begin{array}{lll}
96 & 8 & 2.0
\end{array}
$$$$
\begin{array}{lll}
138 & 8 & 3.0
\end{array}
$$$$
\begin{array}{lll}
201 & 8 & 4.3
\end{array}
$$$$
\begin{array}{lll}
163 & 7 & 3.1
\end{array}
$$$$
\begin{array}{lll}
139 & 6 & 2.1
\end{array}
$$$$
\begin{array}{lll}
135 & 5 & 1.7
\end{array}
$$$$
\begin{array}{lll}
131 & 4 & 1.3
\end{array}
$$$$
\begin{array}{lll}
131 & 4 & 1.3 \\
123 & 3 & 1.0
\end{array}
$$$$
\begin{array}{llr}
113 & 3 & .92
\end{array}
$$$$
\begin{array}{lll}
13 & -- & --
\end{array}
$$$$
2927 \quad---\quad 39.34
$$

.53
.46
.45
.48
.54
.72
.2
.6
.7
.7
.0
.0
.3
.1
.1
.7
.3
.0
.92
.34

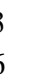

5

8.78


Appendix 3. Daily mean streamflow, daily mean suspended-sediment concentration, and daily total suspended-sediment discharge at three continuous-record sediment stations in the Housatonic River Basin, western Massachusetts, March 1994 through April 1996-Continued

01198125 HOUSATONIC RIVER NEAR ASHLEY FALLS, MA—Continued SEDIMENT DISCHARGE, SUSPENDED (TONS/DAY), WATER YEAR OCTOBER 1995 TO SEPTEMBER 1996

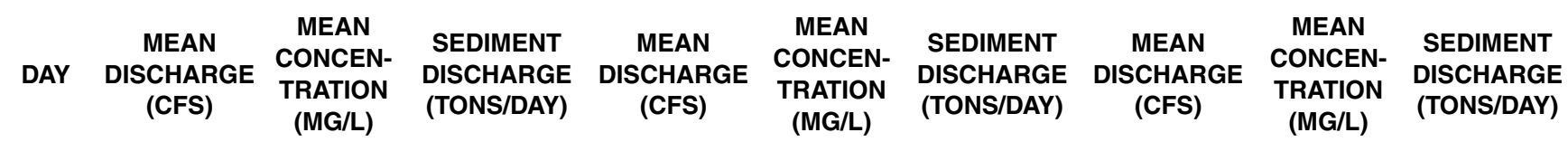

OCTOBER

\begin{tabular}{|c|c|}
\hline 1 & 108 \\
\hline 2 & 103 \\
\hline 3 & 111 \\
\hline 4 & 119 \\
\hline 5 & 170 \\
\hline 6 & 538 \\
\hline 7 & 910 \\
\hline 8 & 788 \\
\hline 9 & 548 \\
\hline 10 & 395 \\
\hline 11 & 321 \\
\hline 12 & 278 \\
\hline 13 & 243 \\
\hline 14 & 219 \\
\hline 15 & 355 \\
\hline 16 & 618 \\
\hline 17 & 534 \\
\hline 18 & 401 \\
\hline 19 & 370 \\
\hline 20 & 353 \\
\hline 21 & 416 \\
\hline 22 & 1630 \\
\hline 23 & 2270 \\
\hline 24 & 2070 \\
\hline 25 & 1330 \\
\hline 26 & 1000 \\
\hline 27 & 861 \\
\hline 28 & 1590 \\
\hline 29 & 2880 \\
\hline 30 & 2910 \\
\hline 31 & 2200 \\
\hline
\end{tabular}

NOVEMBER

\begin{tabular}{|c|c|}
\hline 1540 & 22 \\
\hline 1310 & 17 \\
\hline 1460 & 15 \\
\hline 1420 & 14 \\
\hline 1210 & 14 \\
\hline 1030 & 13 \\
\hline 929 & 12 \\
\hline 1050 & 12 \\
\hline 1130 & 11 \\
\hline 993 & 11 \\
\hline 903 & 10 \\
\hline 1740 & 62 \\
\hline 3180 & 74 \\
\hline 3390 & 69 \\
\hline 3310 & 40 \\
\hline 3120 & 35 \\
\hline 2800 & 31 \\
\hline 2350 & 25 \\
\hline 1970 & 21 \\
\hline 1790 & 18 \\
\hline 1670 & 15 \\
\hline 1520 & 14 \\
\hline 1350 & 13 \\
\hline 1170 & 12 \\
\hline 1050 & 12 \\
\hline 966 & 11 \\
\hline 927 & 11 \\
\hline 886 & 11 \\
\hline 869 & 10 \\
\hline 884 & 10 \\
\hline --- & --- \\
\hline
\end{tabular}

DECEMBER

\begin{tabular}{|c|c|c|}
\hline 863 & 10 & 24 \\
\hline 860 & 10 & 24 \\
\hline 828 & 10 & 23 \\
\hline 819 & 10 & 23 \\
\hline 866 & 11 & 25 \\
\hline 864 & 11 & 25 \\
\hline 856 & 11 & 25 \\
\hline 760 & 11 & 22 \\
\hline 682 & 10 & 18 \\
\hline e680 & 9 & 17 \\
\hline e660 & 8 & 14 \\
\hline e640 & 7 & 12 \\
\hline e620 & 6 & 10 \\
\hline e600 & 6 & 9.7 \\
\hline e620 & 5 & 8.4 \\
\hline e640 & 5 & 8.6 \\
\hline e620 & 5 & 8.4 \\
\hline e600 & 5 & 8.1 \\
\hline e580 & 5 & 7.8 \\
\hline e560 & 5 & 7.6 \\
\hline e550 & 5 & 7.4 \\
\hline e550 & 5 & 7.4 \\
\hline e550 & 5 & 7.4 \\
\hline e520 & 5 & 7.0 \\
\hline e510 & 5 & 6.9 \\
\hline e500 & 5 & 6.8 \\
\hline e490 & 5 & 6.6 \\
\hline e480 & 5 & 6.5 \\
\hline e465 & 5 & 6.3 \\
\hline e 450 & 5 & 6.1 \\
\hline e430 & 5 & 5.8 \\
\hline 19713 & --- & 394.8 \\
\hline
\end{tabular}


Appendix 3. Daily mean streamflow, daily mean suspended-sediment concentration, and daily total suspended-sediment discharge at three continuous-record sediment stations in the Housatonic River Basin, western Massachusetts, March 1994 through April 1996-Continued

01198125 HOUSATONIC RIVER NEAR ASHLEY FALLS, MA—Continued SEDIMENT DISCHARGE, SUSPENDED (TONS/DAY), WATER YEAR OCTOBER 1995 TO SEPTEMBER 1996

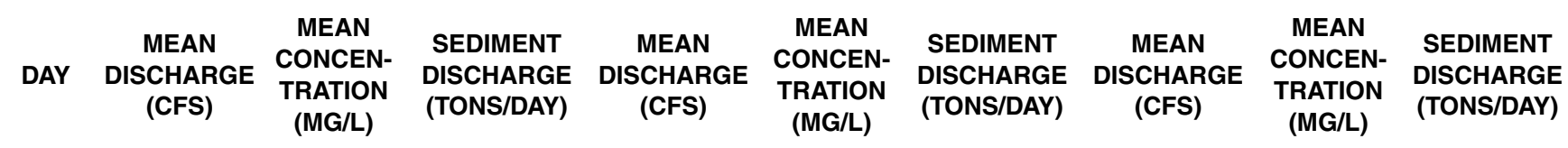
JANUARY

FEBRUARY

\begin{tabular}{|c|c|c|c|c|c|c|c|c|}
\hline e415 & 5 & 5.6 & 2880 & 49 & 380 & 1930 & 30 & 159 \\
\hline e410 & 5 & 5.5 & e2160 & 42 & 245 & 1700 & 27 & 125 \\
\hline e410 & 5 & 5.5 & e1800 & 37 & 180 & 1510 & 25 & 102 \\
\hline e405 & 5 & 5.5 & e1610 & 33 & 143 & 1330 & 23 & 81 \\
\hline e405 & 5 & 5.5 & e1470 & 31 & 123 & 1260 & 21 & 71 \\
\hline e 400 & 5 & 5.4 & e1400 & 30 & 113 & 1350 & 25 & 90 \\
\hline 400 & 5 & 5.4 & e1350 & 29 & 106 & 1430 & 28 & 110 \\
\hline e400 & 5 & 5.4 & 1340 & 28 & 102 & 1290 & 26 & 92 \\
\hline e405 & 5 & 5.5 & 1290 & 28 & 96 & e1250 & 24 & 81 \\
\hline e410 & 5 & 5.5 & 1260 & 26 & 89 & e1160 & 23 & 72 \\
\hline e410 & 5 & 5.5 & 1190 & 23 & 73 & e1110 & 21 & 63 \\
\hline e405 & 5 & 5.5 & 1130 & 19 & 59 & e1090 & 20 & 59 \\
\hline e405 & 5 & 5.5 & 1030 & 17 & 46 & 1070 & 20 & 58 \\
\hline e415 & 5 & 5.6 & e932 & 14 & 35 & 1110 & 21 & 63 \\
\hline $\mathrm{e} 420$ & 5 & 5.7 & e869 & 12 & 28 & 1290 & 28 & 99 \\
\hline e410 & 5 & 5.5 & e835 & 10 & 22 & 1710 & 35 & 164 \\
\hline e410 & 5 & 5.5 & e813 & 9 & 20 & 1650 & 30 & 136 \\
\hline 595 & 5 & 8.0 & e799 & 7 & 15 & 1460 & 22 & 87 \\
\hline 1150 & 49 & 255 & e785 & 6 & 13 & 1360 & 15 & 55 \\
\hline 4100 & 131 & 1400 & 822 & 5 & 12 & 1430 & 12 & 46 \\
\hline 6860 & 65 & 1190 & 1150 & 22 & 79 & 1670 & 16 & 74 \\
\hline 6590 & 38 & 682 & 2360 & 102 & 650 & 1720 & 17 & 81 \\
\hline 5230 & 30 & 423 & 3170 & 107 & 915 & 1560 & 14 & 60 \\
\hline 3940 & 39 & 408 & 3300 & 89 & 798 & 1320 & 12 & 43 \\
\hline 4460 & 91 & 1100 & 3230 & 73 & 640 & 1200 & 10 & 32 \\
\hline 4600 & 85 & 1060 & 2910 & 59 & 468 & 1220 & 10 & 34 \\
\hline 4090 & 58 & 640 & 2470 & 46 & 304 & 1390 & 10 & 39 \\
\hline 5550 & 113 & 1690 & 2190 & 37 & 218 & 1390 & 9 & 34 \\
\hline 5950 & 74 & 1190 & 2190 & 35 & 204 & 1240 & 6 & 21 \\
\hline 5130 & 63 & 878 & --- & --- & --- & 1130 & 6 & 17 \\
\hline 3940 & 56 & 600 & --- & --- & --- & 1060 & 5 & 15 \\
\hline 69120 & --- & 11617.6 & 48735 & --- & 6176 & 42390 & --- & 2263 \\
\hline
\end{tabular}

e Estimated.

a Mean concentration rounded to nearest whole number; associated sediment discharge calculated using unrounded mean concentration. 